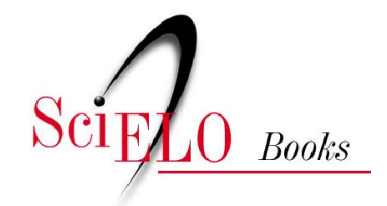

\author{
Work in Brazil \\ essays in historical and economic sociology \\ Adalberto Cardoso
}

SciELO Books / SciELO Livros / SciELO Libros

CARDOSO, A. Work in Brazil: essays in historical and economic sociology [online]. Rio de Janeiro: EDUERJ, 2016, 286 p. Sociedade e política collection. ISBN: 978-85-7511-455-1. Available from: doi: $10.7476 / 9788575114551$. Also available in ePUB from: http://books.scielo.org/id/tskp8/epub/cardoso-9788575114551.epub.

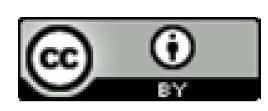

All the contents of this work, except where otherwise noted, is licensed under a Creative Commons Attribution 4.0 International license.

Todo o conteúdo deste trabalho, exceto quando houver ressalva, é publicado sob a licença Creative Commons Atribição 4.0.

Todo el contenido de esta obra, excepto donde se indique lo contrario, está bajo licencia de la licencia Creative Commons Reconocimento 4.0. 


\section{WORK IN BRAZIL: \\ ESSAYS IN HISTORICAL AND ECONOMIC SOCIOLOGY}


Reitor

Ruy Garcia Marques

Vice-reitora

Maria Georgina Muniz Washington

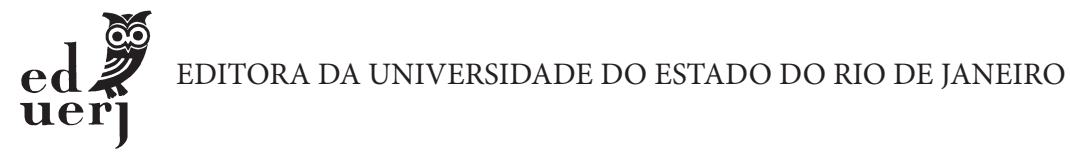

\section{Conselho Editorial}

Bernardo Esteves

Erick Felinto

Glaucio Marafon (presidente)

Jane Russo

Maria Aparecida Ferreira de Andrade Salgueiro

Ivo Barbieri (membro honorário)

Italo Moriconi (membro honorário)

Lucia Bastos (membro honorário)

\section{IESP.UERJ}

\section{Coleção Sociedade e Política}

\section{Coordenadores}

Breno Bringel

João Feres Júnior

Conselho científico

Antônio Sérgio Guimarães (USP)

Fabiano Santos (IESP-UERJ)

Flávia Biroli (UnB)

Gilberto Hochman (FIOCRUZ)

José Maurício Domingues (IESP-UERJ)

Leonardo Avritzer (UFMG)

Maria Stella Grossi Porto (UnB)

Pablo Gentili (CLACSO)

Rachel Meneguello (UNICAMP)

Sergio Costa (Frei Universität - Alemanha) 
Adalberto Cardoso

\section{WORK IN BRAZIL: \\ ESSAYS IN HISTORICAL AND ECONOMIC SOCIOLOGY}

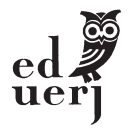

Rio de Janeiro 2016 
Copyright (C) 2016, Adalberto Cardoso.

Todos os direitos desta edição reservados à Editora da Universidade do Estado do Rio de Janeiro. É proibida a duplicação ou reprodução deste volume, ou de parte do mesmo, em quaisquer meios, sem autorização expressa da editora.

\section{EdUERJ \\ Editora da UNIVERSIDADE DO ESTADO DO RIO DE JANEIRO}

Rua São Francisco Xavier, 524 - Maracanã

CEP 20550-013 - Rio de Janeiro - RJ - Brasil

Tel./Fax.: 55 (21) 2334-0720 / 2334-0721

www.eduerj.uerj.br

eduerj@uerj.br

\section{Editor Executivo}

Coordenadora Administrativa

Glaucio Marafon

Coordenadora Editorial

Assistente Editorial

Elisete Cantuária

Coordenadora de Produção

Silvia Nóbrega

Assistente de Produção

Thiago Braz

Supervisor de Revisão

Rosania Rolins

Capa

Mauro Siqueira

Projeto e Diagramação

Elmar Aquino

Júlio Nogueira

Emilio Biscardi

CATALOGAÇÃO NA FONTE

UERJ/REDE SIRIUS/NPROTEC

C268 Cardoso, Adalberto Moreira, 1961-

Work in Brazil : essays in historical and economic sociology /

Adalberto Cardoso. - Rio de Janeiro : EdUERJ, 2016.

$286 \mathrm{p}$.

ISBN 978-85-7511-430-8

1. Sociologia do trabalho - Brasil. I. Título. 


\section{TABLE OF CONTENT}

INTRODUCTION

CHAPTER I SLAVERY AND CAPITALIST SOCIABILITY:

AN ESSAY ON SOCIAL INERTIA

The slow transition to free labour.....................................................................20

Consequences of the slow transition .................................................................22

CHAPTER II A BRAZILIAN UTOPIA: GETÚLIO VARGAS

AND THE CONSTRUCTION OF THE WELFARE STATE

IN A STRUCTURALLY UNEQUAL SOCIETY

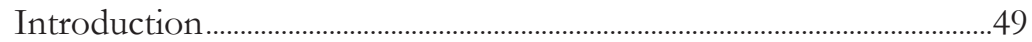

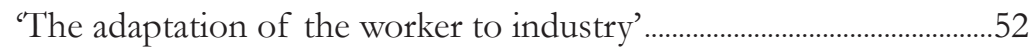

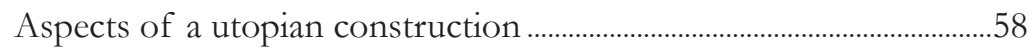

'Regulated citizenship' and beyond.............................................................67

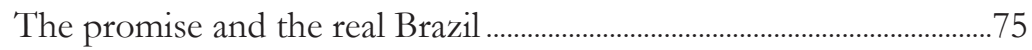

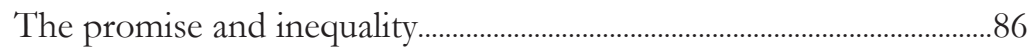

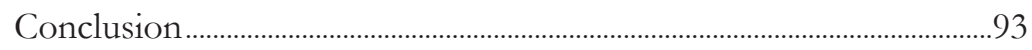

CHAPTER III 'TOMORROW YOU WILL BE THE

GOVERNMENT': THE VARGAS'S UTOPIA

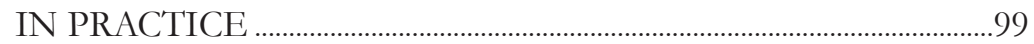

Introduction ............................................................................................................... 99

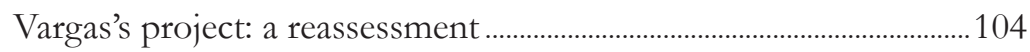

Authoritarianism confronts the Vargas Era ..............................................114

The 'New Unionism' and the Vargas Era .................................................119

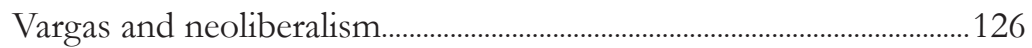


The Vargas's spectre

Conclusion.

CHAPTER IV NEOLIBERALISM, UNIONS, AND SOCIOECONOMIC INSECURITY.

Introduction ................................................................................................139

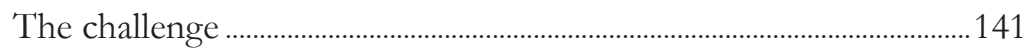

Growth favoured.......................................................................................... 141

The mirror image ................................................................................................ 144

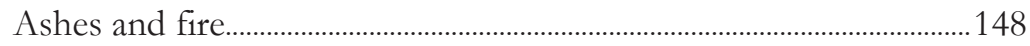

The People's Social Security Survey ............................................................. 151

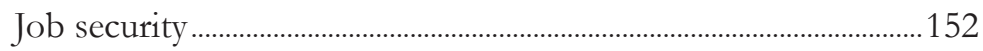

Access to labour rights and welfare........................................................... 155

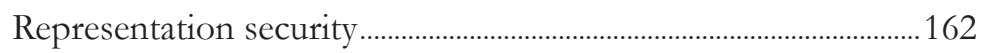

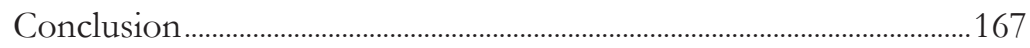

CHAPTER V BRAZILIAN LABOUR MARKET: LIMITS AND OPPORTUNITIES FOR EMANCIPATION ...........................173

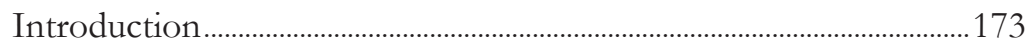

Promises and expectations ...........................................................................176

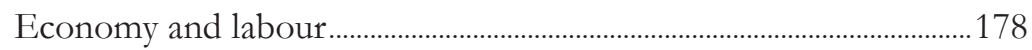

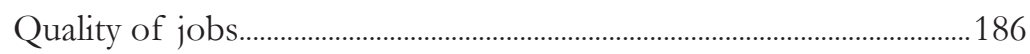

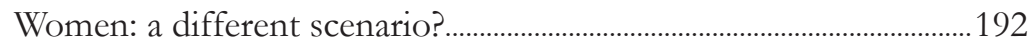

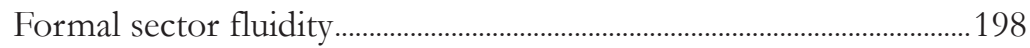

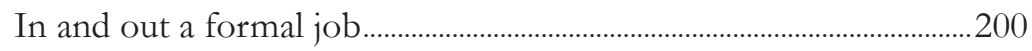

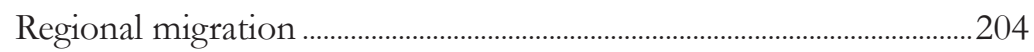

A 'new middle class'? ..............................................................................................2 207

Younger and new generations ...........................................................................208

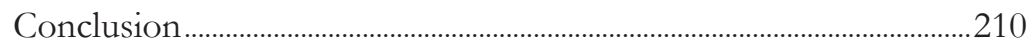

CHAPTER VI LABOUR INSPECTION IN BRAZIL (WRITTEN WITH TELMA LAGE) ..................................................2215

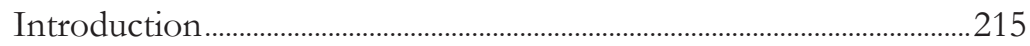


The costs of obeying or disregarding labour laws

A brief historical overview ................................................................................224

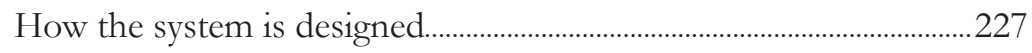

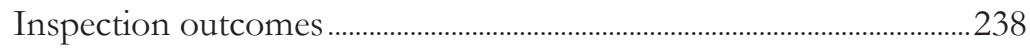

Labour inspection in Rio de Janeiro's civil construction industry. 245

The Chances of Getting Caught .........................................................246

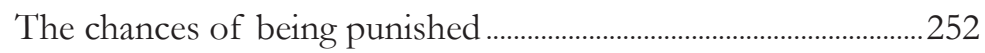

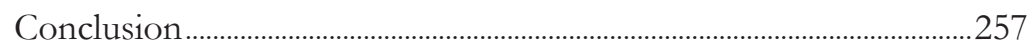

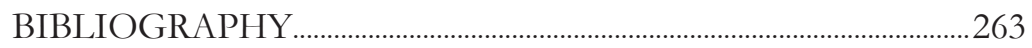

ABOUT THE AUTHOR …………………………………………………….....2. 285 


\section{Index of Graphs, Tables and Figures}

Graph A Evolution of urban EAP, number of work books (carteiras de trabalho) issued by the Ministry of Labour and number of contributors to social security: Brazil, 1940-1976

Graph 1 Strikes and strikers in 20 years

Graph 2 Judicial demands in the first level of labour courts in Brazil, 1941-2000

Graph 3 Type of job by age groups: men of 20 to 59 years

Brazil, 1981-2009.

Graph 4 Mean time of employment (months) in the current job, by type of job. Brazil: 1992-2009.

Graph 5 Labour market probabilities of women, 30-34 age group. Brazil, 1981-2009

Graph 6 Proportion (\%) of registered jobs (public or private) occupied by men and women and the gender odds ratio:

Brazil, 1981-2009

Graph $7 \mathrm{Men}$ /women ratio of the median hourly earnings by type of job. Brazil, 1981-2009

Graph 8 Probability of being in a formal job in two different periods.

Men of 20-23 years: 202

Table 1 Evolution of union density rates of the Salaried Occupied Population (SOP) above the age of 18, and of Registered Salaried Workers (RSW) above the age of 18, 1988-2001.

Table 2 Impact of union affiliation on measures of job security $(\%)$

Table 3 Index of access to legal and contractual benefits and union affiliation 
Table 4 Multivariate linear regression (OLS) on the index of access to legal and contractual benefits

Table 5 Prospects for life at the age of 60 and union affiliation (proportion who responded yes)

Table 6 Proportion of union and non-union members saying that political and social institutions are trustworthy

Table 7 Participation in social and political institutions and union membership

Table 8 GDP by Economic Sectors (per cent share) - Brazil, 1950-2010

Table 9 Duration of formal salaried jobs for men and women, and mean age in each category. Brazil, mean proportions and age for 1992-2009

Table 10 Total number of Jobs of workers admitted in the São Paulo and Rio de Janeiro Met. Regs. in 1994, according to the original 1994 occupation, and geographical destiny in the 1985-2008 period 206

Table 13 Ministry of Labour Investment Budget and its

Share of the Overall Federal Budget and of the Ministerial Budget: 1995-2003

Table 14 Labour Inspection by the Regional Labour Offices (DRTs) Brazil, 1990-2003. 239

Table 15 FGTS Inspection - Brazil, 1996-2002 244

Figure 1 Opportunity Structure for Compliance with Labour Legislation. 219

Figure 2 Labour Fines for Selected Infractions 222

Figure 3 Structure of the Ministry of Labour - 2004 228 


\section{INTRODUCTION}

This book is about Brazil, the country I live in, the country I love, the country that haunts me with its Sphinxshaped sociability. For the last 25 years or so I've been researching and publishing on various aspects of the Statecapital-labour relations, and then State building, inequality and class formation, and then youth and informality. The array of issues that interest me is widening as I struggle to understand our Sphinx. Frustration is inevitable.

Brazil has changed enormously in the last five or six decades and more intensely in the last 15 years, at a pace that makes it easy to misguidedly take glittering surface fluctuations as the 'reality' of its ingrained social dynamics. The challenge of any analyst of our world is to try and avoid the blinding shine of the 'new' and to unveil the deep rooted structural and cultural forces that guide change. In Brazil, as anywhere else, the new is always heir of multiple dimensions of the past, and the past, in our case, is marked by social and political authoritarianism, deep socio-economic inequalities, racism, social injustice, poverty, vulnerability of the majority of the population, meagre social policies, a rachitic welfare state... the list is long. While acknowledging and celebrating changes, one must always call attention to the internal mechanisms that, very often, limit the number of Brazilians that benefit from them. This is what I try to do in this book, focusing on selected aspects of the social, political, institutional and economic dimensions of our Sphinx. 
The chapters I present here were either written in English or translated into it for somewhat fortuitous reasons. In conversation with friends around a bottle of wine (actually several bottles...) it occurred to us that our ideas about, and our understanding of Brazil should reach wider audiences than those who read Portuguese. Foreign scholars interested in Brazil need to grasp our language if they want to do serious theoretical or empirical research and when they do, they invariably publish in their native languages before having their work translated into Portuguese, so their ideas reach us second-hand. But they eventually do reach us, while our ideas and research and our interpretation of Brazil, if written in Portuguese, reach only the interested scholar. Of course, there are many Brazilians working in universities and research centres around the world, but foreign academic communities have rules of their own, and to be accepted as an internationally-respect scholar, a Brazilian must learn how to think and write like an American or French or German, otherwise he or she will not be published in the journals for which the peer review is most often exercised by established Anglophone (or Francophile, or Teutonic) Brazilianists or Latino-Americanists, who may be predisposed to reject arguments that contradict the mainstream interpretation within each country's community of Brazilianists and LatinoAmericanists. Those of us who have tried to publish in a foreign journal know what I am talking about.

As a consequence, the world knows little about the vigorous Brazilian social sciences. Most of what is canonical about what we 'are' was not established by us, but by Brazilianists or by Latino-Americanists writing about us in the US or elsewhere. Of course, the list of excelling figures that made empirical research on, and wrote about Brazil includes Claude Lévi Strauss, Anthony and Elisabeth Leeds, Robert K. Merton, Alberto O. Hirschman, Alfred Stepan, Phillip Schmitter, Ruth Collier, 
David Collier, Thomas Skidmore, Leslie Bethel, John French, Brodwin Fisher... The list is lengthy, and their work is actually very good and has certainly helped us understand ourselves. But their gaze, welcome as it is, is inevitably that of the stranger, and very often theories and concepts developed in the North are 'adapted' to our reality, which results in arguments built either in the negative (Brazil does not have a developed democracy, lacks republicanism...) or underlining its alleged specificities (its deep inequality, its corrupted politics, its violent sociability, its 'sub-citizenship'), that is, the strangeness and otherness of its configuration. Even the more recent theories on 'multiple modernities' have led to ideas such as 'globalization from below' and to a growing field of research on 'subaltern studies', and they also tend to emphasize the uniqueness of the 'global south', Brazil included.

We live in a global world. Social theories must be general enough to account for the diversity of the world without individualizing particular geographical areas as unique or specific. Of course, we do have our particularities (otherwise I would not have used the metaphor of the Sphinx), but as in any other country or region in the world, the particular is a case of the universal. We are a democracy, a republic, a financedominated capitalist economy with its cycles. We have a State, a welfare state, borders, geopolitical interests, in and emigration. We have political disputes on the horizons of the good life, political competition, social parties, social classes, class struggle. We have cities, metropolises, megalopolises. We have social violence, police violence, political violence, symbolic violence. Information technologies are the element of our lives, global warming is affecting us deeply, and risky environments are a product of our capitalism, as anywhere else. All these concepts and analytical frames fit. We are not unique in every respect, but we have our particularities, as has any other country. 
This book focuses on a very small cluster of these particularities. Because the chapters were written in the last 13 years for different purposes and for different audiences, they differ somewhat in style, research design and approach. But they do have a general background: the investigation of some of the multidimensional legacies of the Getúlio Vargas's Era. Even Chapter I, on slavery and the transition to free labour at the turn of the $20^{\text {th }}$ Century, was written to make intelligible the enormous changes brought about by the advent of the Vargas Era in the 1930s. Most of the institutions created under Vargas's rule (1930-1945 and 1951-1954) are still with us. Statelabour-capital relations are still framed by those institutions. The labour market is still regulated by laws enacted in the 1930s and consolidated in 1943. Collective bargaining, labour inspection, the labour and capital organizations are all elements of the Vargas legacies that, albeit with adaptations over time, still impinge upon our present. For that reason, it is impossible to understand what we are without looking back and trying and reconstruct the trajectories of the current institutions, social and political actors, and even the economy. As a consequence, four of the six chapters adopt a historical sociological perspective, in dialogue between the contemporary context and the country's vivid historiography. The other two benefit in one way or another from this dialogue.

Based on historiographical studies that since the 1980s have undertaken a broad review of the social history of labour in Brazil, Chapter I presents a number of sociological hypotheses about the permanence of structural features of the 'slavery past' in the process of building of the capitalist sociability in the country. This legacy includes the perceived depreciation of manual work, a derogatory stereotype for black and the Brazilian laymen as workers, a moral indifference of the elites toward the fate of the poor (who constituted the large majority 
of the population), and extremely rigid social hierarchies. This framework of structural inertia provided the general parameters of free labour's reproduction in the beginning of capitalist order in Brazil, structuring the life chances of native Brazilians, exslaves and their offspring and also the European immigrants in the first decades of the $20^{\text {th }}$ Century.

Chapter II joins the persistent (and recurrent) effort to decipher the riddle of Brazil's equally persistent inequality. Resuming the interpretation of modern Brazil proposed by Juarez Brandão Lopes in the 1960s, the chapter revisits the 'Vargas Era' and its historical meaning and scope, in light of the reproduction of inequalities over time. I propose that 'regulated citizenship', a concept crafted by Wanderley Guilherme dos Santos in the 1970s, captures the bulk of the social dynamic of the Vargas Era and beyond, for it generated the expectation of social protection among Brazilian workers, feeding the promise of citizens' integration which, however, was never actually fulfilled. This gave the social order a double coordination mechanism: incorporation nourished workers' expectations, resulting in extensive migration from the countryside to the cities and there producing urban poverty, urban violence and urban inequalities; and at the same time, because the social and labour rights that defined the 'regulated citizenship' were part of the federal constitution and the legal system that defined the State, but were ineffective in practice, workers had to fight to make them real. As a consequence, while struggling for the validity of the social rights, workers were incorporated as an integral part of the Brazilian state-building process.

In Chapter III I develop the argument further, scrutinizing the long-lasting consequences of this double coordination mechanism for the social and political dynamics from Vargas to Lula. I show that the communists and other left-wing factions of the labour movement strongly opposed the union structure 
created by Vargas after the end of his dictatorship in 1945, but soon adhered to its appealing elements, most particularly the control over official unions and their legally assured financial mechanisms and their captive represented workers, which assured labour leaders social and political power. The military rule (1964-1985) was a first attempt to bomb down the pillars of the Vargas's legacies, in part because it had allegedly empowered the communists and, in the paranoid view of the militaries and the civil elites that supported them, fuelled a project of a 'syndicalist republic' in the tropics. But the military rule failed in its intent to expunge Vargas and its ingrained heritage, for the major opposition agent that forced the end of the dictatorship was, precisely, the 'new unionism', or the labour movement nurtured within the Vargas's union structure which the military thought they controlled. The 'new unionism' was itself a second intent to contend the Vargas's institutions, for its project was to substitute the law (the Vargas's legacy was a legislated labour relations' system) by a national collective contract bargained by free unions. This project was abandoned in the 1990s when neoliberalism targeted the labour market regulations and their 'rigidities'. Even the 'new unionists' dig trenches against the reforms and became ferocious guardians of the Vargas's institutions. With the advent of Lula in the 2000s many of these were renewed, engorged or perfected.

The fourth chapter explains in depth why the 'new unionism' adhered to the Vargas's legacies in the 1990s. The Brazilian trade unions faced a multidimensional crisis of representation as a consequence of structural shifts in the social and economic conditions of union action and of unresolved institutional dilemmas in the union structure established by legislation in the Vargas era. These two vectors have joined to undermine the very basis of the unionism consolidated in Brazil since 1978, dramatically reducing the ability of unions 
to represent their constituencies' interests. The chapter first discusses the general conditions that favoured union growth in the 1980s. It then moves on to a brief description of the changes that occurred in the 1990s and the consequences of these changes for the inherited pattern of unionism. Next, collective action and union density data are scrutinized in order to show how these changes affected the main pillars of that heritage. An analysis of the findings of the People's Social Security Survey (PSS) conducted in Brazil in 2001 is then presented. The analysis shows how the structural changes affected unions' efficacy and efficiency in interest representation. The conclusion connects the various dimensions of the crisis. I could have updated the discussion, but the arguments made in 2002, when the chapter gained its final form, are still valid, so I only made minor stylistic revisions.

Mobilizing Census data, household surveys and administrative records, Chapter $\mathrm{V}$ advocates taking a longterm perspective on the structure and dynamic of the Brazilian labour market. It shows that the country has been faced with considerable social, economic and demographic inertia resulting from long lasting economic stagnation and poor growth rates, which have affected successive generations in the 30 years ending in 2012, and have created a new kind of labour market dual dynamic which is seldom taken into account in mainstream analysis and public debate. A substantial proportion of the 40 percent of the labour force informally occupied in 2009 are no longer employable in the formal labour market. In addition, the growing formal labour market is not creating enough jobs to accommodate the new generations of workers, many of whom are restricted to long periods of unemployment or of precarious informal jobs before they are 'entitled' to a formal, regulated position. And this position, once attained, is unstable for most workers. If things are much better today than they used to be 
for a significant proportion of the labour force, their stability and sustainability, if maintained in the future, are no guarantee of better labour market positions for what I call here the lost generations that have had to make their living in very precarious economic environments in the past.

Lastly, in Chapter VI I argue that the literature on the effects of labour market regulations on market efficiency often overlooks the degree of the legislation's effectiveness (i.e. its actual enforcement in daily labour relations). Even the more sophisticated econometric studies that take into account the interaction effects between labour market regulatory institutions in explaining its dynamics leave this central issue aside, namely, enforcement versus non-enforcement of the law. Keeping this issue in mind, this chapter (which was written with Telma Lage) seeks to answer the following question: given that the effectiveness of labour legislation depends on the interaction between the overall sanctions and the probability of the employer getting caught breaking the law, and given that the law's effectiveness is a decisive aspect for the real measurement of a country's labour costs, to what extent is the Brazilian labour inspection system designed to meet its objective, namely, to enforce the law? Lage and I inquire on the design and functioning of the labour inspection mechanisms to show that, all in all, the system is not able to reduce informality and does not target small and medium firms, more prone to evade the law.

Institutional frameworks, political action, social and political identities, class relations, social inertia and path dependence are the main aspects inquired in this book. Taken together, the chapters present a coherent and systematic portrait of Brazil, or a plausible point of view about the dynamics of our sociability which, so I hope, may interest the foreign reader. 


\section{CHAPTER I \\ SLAVERY AND CAPITALIST SOCIABILITY: \\ AN ESSAY ON SOCIAL INERTIA ${ }^{1}$}

Over the last two decades the social history of labour has experienced a seachange in Brazil with the routinization of rigorous empirical investigation by stable research groups in diverse academic institutions. This work has led to the discovery of new sources, innovative exploration of old documents, the proliferation of new hypotheses and the emergence of new categories of explanation. The present essay on Brazilian social inertia makes use of this new historiography in order to formulate a number of sociological hypotheses on the pattern of incorporation of workers in the early stages of capitalism in Brazil. I suggest that slavery left profound marks on the ensuing social imagination and practices, functioning as a kind of ballast that subsequent generations found extremely difficult to jettison. Around slavery were constructed an ethics of demeaning labour, a pejorative image of the people or the national workforce, the moral indifference of the elites to the needs of the majority and a highly rigid social hierarchy polarized by enormous inequalities. Combined, these legacies shaped the environment in which free labour developed at the end of the $19^{\text {th }}$ century and the start of the $20^{\text {th }}$, determining the wider parameters of social

1 Translated by David Allan Rodgers from Novos Estudos Cebrap, No. 80, p. 71-88, Mar. 2007, for the Scielo Social Sciences (http://socialsciences.scielo.org/ scielo.php?pid=S0101-33002008000100003\&script=sci_arttext). 
reproduction. Here I look to reconstitute the multidimensional nature of the legacy of slavery on the capitalist sociability as the first step in a wider argument concerning the conditions of the reproduction of social inequality in Brazil ${ }^{2}$.

\section{The slow transition to free labour}

One salient aspect of the contemporary revision of historiography is the recognition of slavery as a specific moment in the history of labour in the country ${ }^{3}$. For reasons that are not immediately obvious, but which are linked more to disciplinary dynamics than the world order, the studies of slavery have formed part of the genealogy of a branch of social investigation that could be denominated 'race relations', while investigation of the early constitution of the work society in Brazil has traditionally taken European immigration as its foundational moment. This approach was not inevitable given that an eminent thinker like Florestan Fernandes was initially interested in the fate of the former slaves. For him, this 'marginal' (or 'maladjusted') figure expressed the ills endemic to the construction of Brazil's competitive social order. Fernando Henrique Cardoso and Octávio Ianni, disciples of Fernandes, also explored the topic from the same angle. In historiography it is worth recalling the pioneering work of Emilia Viotti da Costa and the studies of Brazilianists such as A. J. R. Russell-Wood, Stuart Schwartz,

2 The chapter must be read as an introduction to the wider argument, the developments of which was published in Cardoso (2010). The ideas represented here were gestated during two courses I gave at IUPERJ in 2006 and 2007 on the transition to free labour and class formation in Brazil. My sincere thanks to the masters and doctoral students who honoured me with their dedication and debates. Naturally they are exempted from any mistakes that may still remain.

3 Cf. Negro and Gomes (2006). For a wide-ranging synthesis of this new historiography, see Fragoso (2000), whose central theses are radicalized in Fragoso and Florentino (2001). 
Robert Conrad, Peter Eisenberg and Herbert Klein, to cite just some of those who examined the social fate of ex-slaves under the slavery regime.

The reason for this disciplinary division perhaps resides in a certain matrix of ideas promoted from the 1950s onwards in which it was presumed that modern Brazilian capitalism had first emerged in São Paulo, meaning it would be sufficient to search there for its socioeconomic roots. This idea persisted even after Celso Furtado had shown, in the 1950s still, that while the capital freed by coffee production lay at the origin of the industrial accumulation of São Paulo (and, by extension, Brazil), capitalism in the country was unequal but integrated, such that the fate of the Northeast or Amazonia was not disconnected from the São Paulo dynamic. As a result, the vast literature on the consolidation of capitalism and the labour market in Brazil had an undeniable 'São-Paulocentric' flavour.

The concentration of research funds in the latter state was a necessary condition for this development, but not a sufficient one. Just as important was the notion of modernity that informed the elaboration of economic and social research programs not only at the University of São Paulo (USP) but also the Higher Institute of Brazilian Studies (ISEB), the Federal University of Rio de Janeiro (UFRJ) and the Getúlio Vargas Foundation $(\mathrm{FGV})$. This notion dictated that any country wishing to modernize had to be capitalist, industrial and urban, marking its position in the community of nations, moreover, from a selfdetermined position, a feat only possible if it managed to create the internal conditions for economic development. Here we can identify at least part of the reason why until very recently the transition to free labour has been interpreted in conjunction with overseas immigration, insisting on a sharp break between the slave-based economy of the past and the new competitive environment. It is as though the slavocratic regime had been 
buried with abolition without passing on to the future any of its general dynamic (and inertia). Qualifying and complicating this interpretation, the more recent literature enables us to formulate strong hypotheses that emphasize, along with the evident ruptures, deep continuities with the earlier slavery system in the process of building capitalism in Brazil ${ }^{4}$.

The first hypothesis is that the São Paulo model of transition to free labour was by no means typical or representative of what happened in the rest of the country. In many ways, São Paulo was the exception, since it was only there that immigration was presented (and implemented) as the sole possible solution for what contemporaries perceived as the 'workforce problem'5. In states like Minas Gerais, Rio Grande do Sul, Bahia, Pernambuco, Ceará or Maranhão, production work (in farming or mining, in the pampas or in the towns) was gradually taken over by former slaves and their descendants, as well as free Brazilians. Previously seen as merely peripheral agents in the slavery system, the social status of the latter has been entirely revised by new research. In Pernambuco, for example, at the start of the 1870s when immigration had already won over the minds of the São Paulo elite, most rural work was undertaken by free men whose smallholdings had been expropriated from the end of the $18^{\text {th }}$ century onwards, as Palácios (1996: pp. 12728) demonstrates. According to the author, this led analysts

4 The historiographic revision of the transition to free labour does not apply to the Brazilian case only. On the Argentine case and on the Americas in general, see, respectively, Johnson (1997); and Turner (1995). Adopting a somewhat radical approach, Marcel van der Linden (2005) proposes a complete restatement of the history of the working class in the world.

5 This question, analysed in the seminal book of Celso Furtado, Formação econômica do Brasil (Rio de Janeiro: Fundo de Cultura, 1959), was evidently a burning issue for São Paulo's coffee-growing elites, as shown by Dean (1977). The topic was re-examined in an excellent work by Azevedo (1987), especially chapters II and III. In relation to the Brazilian northeast, see Andrade (1980 [1963], pp. 88-93). 
of the transition to free labour to believe that the process had been 'smooth' and 'painless' in Pernambuco, when in fact the (violent) expropriation of the peasantry had taken place decades earlier, freeing the workforce needed by sugar plantations from the 1850s onwards, a period during which the exodus of slaves to the São Paulo coffee industry intensified. This phenomenon occurred throughout the Northeast ${ }^{6}$, as well as Minas Gerais and the South: when foreign immigration to São Paulo began, captive labour represented just a small minority. These events suggest that there was not just one single transition to free labour (or, as Fragoso, 2000 suggests, to 'non-slave' labour, since in the $18^{\text {th }}$ and $19^{\text {th }}$ centuries most free men were subject to various forms of forced labour), but various transitions at distinct historical moments across different regions of the country.

Regional differences in the pace of transition reflect another important aspect of the slavocratic system: the existence of distinct forms of slavery. Today we have a much clearer understanding of the different regimes for subjugating captives employed in the sugar plantations of Pernambuco or Bahia, the southern Brazilian pampas, the gold and diamond mines of Minas Gerais, the coffee plantations of the Paraíba Valley, the small towns in the interior of São Paulo state, or large cities such as Rio de Janeiro and São Paulo. In the case of sugar production, for example, occupational hierarchies distinguished slaves according to their adeptness in using machinery, their capacity to produce sugar to a particular standard of quality and so on, generating expectations of social mobility and emancipation that

\footnotetext{
6 'In the Northeast, abolition took place without major readjustments and the former slaves were incorporated into the different sectors of the region's rural workforce. Their fate was subsequently conditioned by the region's economic and social immobility'. (Hasenbalg, 2005 [1979]: p. 164). Hasenbalg also draws attention to the exceptional nature of the São Paulo case, which extensively incorporated the black population into the expanding capitalist labour market (cf. Hasenbalg,1992).
} 
simply did not exist in the sugarcane and cotton fields (Eisenberg 1974 and 1989).

In the Northeast, small slave owners tended to form less predatory relationships with their workforces, bought at relatively high prices for the economic resources of the majority. They allowed slaves to form families and often released captives in their wills. Furthermore the low capitalization of most of the North-eastern properties meant that slavery coexisted with free (or non-slave) labour at moments of peak demand, such as the sugarcane harvesting period (Andrade, 1980). Smallholders who were more or less independent of the big estate owners were called upon seasonally to work on the lands of the slave owners (Schwartz, 1992). This practice was less frequent in the wealthier regions or on the large sugar plantations where owners had the resources to purchase the slaves needed for the work.

In the city of Rio de Janeiro slaves had considerable freedom of movement since most of their owners lived from their work as street vendors, palanquin (sedan chair) carriers, or water and waste bearers for wealthy families, or indeed any kind of job compatible with their status as 'paid' or 'rented' slaves (Karasch, 2000; Chalhoub, 1990; Florentino, 2005), many of whom managed to buy their freedom eventually with their savings ${ }^{7}$. This situation contrasted profoundly with the slavery conditions found on coffee plantations in the Paraíba Valley, typified by long working days and very few chances of ever being freed. In addition, $19^{\text {th }}$ century slavery was very different, especially from 1850 onwards when the price of slaves rose steeply and the predatory use of slaves typical to earlier centuries became economically unviable.

Debret's estimates for Rio de Janeiro suggest that in fifteen years a 'rented slave,' escravo de ganho, would have earned enough to purchase his or her freedom (cf. Fragoso, 2000; Karash, 2000). On the case of 'rented slaves' in São Paulo city, in many ways similar to the situation in imperial Rio, see Dias (1995). 
The identification of different slavery regimes has shown that colonial Brazil was not a homogenous territory dominated by monocrop plantations, nor was its social structure as simple as presumed by the literature produced at least until the start of the $1970 \mathrm{~s}^{8}$. Slaves and landowners undoubtedly comprised the core social classes, but there was a series of other groups who also played an important role in sustaining the slavocratic system, including artisans and craftsmen from the urban guilds, traders, cattle drivers, livestock breeders, small food producers for the domestic market, slave traders, financiers, militiamen, builders, supervisors, small rural landowners producing for themselves, and so on. Moreover, large tracts of land planted with a single crop and employing hundreds of slaves was an exception rather than the rule, both during the colonial period and afterwards.

Indeed a census conducted in Bahia in 1788 recorded an average number of slaves per property varying between 4 and 11.7 across the different regions of the Bahian Recôncavo. In 1816-17 when the overall slave population corresponded to nearly $31 \%$ of the Brazilian population, the average across the Recôncavo as a whole was 7.2 slaves per proprietor. True, the richest $10 \%$ owned at least half of the total slaves, but even so the average number of slaves on these large properties was 34 people (Schwartz, 1995). Similar ratios were encountered on the large São Paulo farms in the first three decades of the $19^{\text {th }}$ century: in 1804 just 1\% of farm holdings had forty slaves or more and held 13\% of the total slave population; in 1829 these figures had risen, but even so large properties accounted for just $3 \%$ of the total, holding $24 \%$ of the total number of slaves (Luna and Klein, 2003: p. 122). The general average was no higher than

\footnotetext{
8 The classic Casa-grande \& senzala, by Gilberto Freyre, adopts this simplifying view of colonial Brazil's social structure. A systematic analysis that influenced generations of researchers was Formação do Brasil Contemporâneo, by Caio Prado Júnior.
} 
7 slaves per proprietor. The situation was no different during the same period in the towns of Minas Gerais, the Zona da Mata of Pernambuco or the interior of São Paulo state (Luna and Klein, 2003: p. 166) ${ }^{9}$. In some regions of Paraná slavery had already become relatively insignificant by the second half of the $18^{\text {th }}$ century, and the properties producing subsistence crops were run by families that bore no similarities, for example, to the patriarchal Pernambucan families depicted by Gilberto Freyre ${ }^{10}$.

One important consequence of identifying distinct slavery regimes has been the observation that even as early as the $18^{\text {th }}$ century slave labour coexisted with various forms of non-slave labour. This means that the transition to free (or non-slave) labour was extremely slow with a merely conventional landmark being established in 1850, the year the international traffic of African slaves was abolished. Free or freed people swelled in number over the centuries, obtaining forms of livelihood that increasingly lost the peripheral nature attributed to them by the literature until the mid-1980s ${ }^{11}$.

At the same time, the mortality rates of Brazilian slaves were very high in comparison to those of the United States, for example, and here recent historiography corroborates the standard interpretation ${ }^{12}$. Compiling data from numerous sources, Schwartz shows that in Brazil in the last quarter of the $19^{\text {th }}$ century the life expectancy of slaves at birth was around 19 years (Schwartz, 1995: p. 303). The horror provoked by this figure in the contemporary reader is perhaps only dampened slightly by the knowledge that the life expectancy of a non-slave

\footnotetext{
9 See also Eisenberg (1974) and Moura (1998).

${ }^{10}$ Cf. Machado (2006). The article resumes the hard-hitting criticism of the Freyrian model of patriarchalism formulated in Corrêa (1994). The author reveals that in São José dos Pinhais, Paraná state, 58\% of slave owners possessed just four captives or less.

${ }^{11}$ Cf., for example, Kowarick (1987) and Souza (2004 [1982]).

${ }^{12}$ For example, the interpretation found in Furtado (1959: chap. 21).
} 
Brazilian was just 27 years in 1879. In the United States the life expectancy of slaves was 35.5 years around 1850 , just $12 \%$ less than that of the population as a whole and much higher than that of the average Brazilian. Living conditions in the colony and for a considerable part of the $19^{\text {th }}$ century were bad for everyone and much worse for slaves. This led Schwartz to conclude that the system was unsustainable without the transatlantic traffic and the continual replacement of the slave population, dying in their thousands each year.

While this is true - that is, while the Brazilian slavocratic system was indeed highly predatory in its treatment of the slave workforce - it is also the case that manumission formed a constitutive element of the different slavery regimes implemented in the country. In the sugar mills of Bahia or Pernambuco, the gold mines of Minas Gerais, the cattle ranches of the South, the city of Rio de Janeiro, the São Paulo coffee plantations, the cotton fields of the Northeast - in every part of Brazil women employed in the manor houses, illegitimate children of whites, or old, sick and incapacitated slaves acquired their freedom. Many captives eventually purchased their liberation with the savings from their work - 'rented slaves' (escravos de ganbo) in Rio de Janeiro and Minas Gerais are the classic examples, but not the only ones ${ }^{13}$. In the town of Campinas, in 1829, 8.6 per cent of the owners of one to nine slaves were black or brown (Fragoso, 2000: p. 155), a statistic that indicates the very real possibilities not only of freedom but also of the social mobility of former captives and their descendants. Furthermore slaves are known to have ran away in large numbers, a phenomenon that generated considerable social tension throughout the $19^{\text {th }}$ century.

${ }^{13}$ On 'rent slaves' in Rio de Janeiro, see Karash (1987); Sampaio (2005). For the Minas Gerais case, see Russell- Wood (1999: chap. 7). 
Thus the transition to free labour in Brazil was not necessarily a transition to capitalist or wage labour ${ }^{14}$. Over the centuries, captives and/or their descendants freed themselves from slavery and began to make up the growing population not directly involved with the slave economy and which became increasingly mixed. In 1850, when the Atlantic slave traffic was abolished, there were around two million slaves among a total population estimated at eight million people (Oliveira Vianna, 1920), more than $90 \%$ of whom lived in rural areas. The workforce had already ceased to be predominantly composed of slaves. The demographic census of 1872 recorded nearly ten million Brazilians, 1.5 million of whom were captives. How can we consider the $75 \%$ of Brazilians who were not or no longer slaves in 1850 peripheral or irrelevant to the system? ${ }^{15}$ This heterogenic group, the majority impoverished, scattered across the country and accustomed to migrating constantly in search of a livelihood ${ }^{16}$, did not participate directly in the dynamic sector of the economy (which by then had shifted to the São Paulo coffee plantations) but they were part of the wider social dynamic. Undoubtedly the means of survival available to this group were limited and extremely uncertain, very often gravitating around

${ }^{14}$ The most important studies in this area, especially on the $18^{\text {th }}$ century, are contained in Russell-Wood (1999). An excellent survey of the vast bibliography produced up until the 1980s is found in Schwartz (1992).

15 As Georges Duby (1987) points out, medieval European society produced its own contingent of 'disgraced' or 'maladapted' folk, but as small minorities, not as the most likely fate of non-slaves. Also see Castel (1998: pp. 119ff).

16 'The [Brazilian] population grew dizzyingly during the $18^{\text {th }}$ and $19^{\text {th }}$ centuries, the lands were appropriated by capital and the growing pauperization forced people to relocate continuously' (Moura, 1998: p. 27). During the same period, southern Brazil, for instance, served as a magnet for the vast non-white free or freed population coming from other regions, who settled in rural areas to produce subsistence goods far from the Colony's general economic dynamic (cf. Lima, 2002). Franco (1997) shows how nomadism was typical to the poor populations under the slavocrat system, ref a decisive aspect in terms of weakening social ties. See also Huggins (1985). 
the large properties, meaning they could be considered captives of other mechanisms of subjugation, such as tenant farming and share farming. Yet even so their status was unequivocal, albeit defined in negative form: they were a group composed of nonslaves (Costa, 1999; Fragoso, 2000).

\section{Consequences of the slow transition}

This process of slowly constructing a free population - which, though not directly involved in the universe of socioeconomic relations defining the hegemonic structure of the Brazilian Colony and Empire, cannot be considered peripheral or superfluous - was decisive in terms of shaping post-slavery Brazil. I focus on five consequences with a direct relevance to what interests me here, namely, the social configuration that gave meaning to the class relations woven during the early constitution of the 'competitive social order' in Brazil.

Firstly, the São Paulo choice of immigrants as the solution to the 'workforce problem', in detriment to the national population, is a clear expression of the widespread inertia of the social structure in crisis. The São Paulo capitalists even took 'primitive accumulation ${ }^{17}$ to be a possible unfolding of the 1850 Land Law, which denied access to unoccupied lands to those unable to purchase them, thereby preventing former slaves and future immigrants from obtaining legal access to a plot $^{18}$. However, the big question that drove on the Paulistas was whether the national population could be expropriated. For a long time this burgeoning population had lived in close interaction with Brazil's slavocratic society in vulnerable (but stable) conditions of survival, only

\footnotetext{
${ }^{17}$ As had occurred in Pernambuco in the $18^{\text {th }}$ century, as shown by Palácios (1997).

${ }^{18}$ In the felicitous expression of Martins (1979), the condition for the end of captivity for human beings was making the land captive.
} 
indirectly associated with market production ${ }^{19}$. Perhaps it would be possible to force the 'vagrants' to sell their labour by law, under penalty of imprisonment or physical punishment. But how far would the definition of vagrancy need to be stretched for it to encompass all the workforce required by the expanding coffee production, including, for example, small leaseholders or the small land and livestock owners scattered across the vast province of São Paulo? This alternative would require a police force distributed throughout the territory, something which did not exist ${ }^{20}$, or the hiring of large private militias, unthinkable at a time when all available capital was being channelled towards coffee production.

But this inertia was manifested at another level, a deeper one since it was the direct result of the effect of centuries of slavery on the imagination of the São Paulo elite. The debates in the province's Legislative Assembly during the 1870 s and afterwards, opposing those for and against foreign immigration, reveal the strong resistance from most of the governing elite to incorporating the national population in coffee production through a combination of financial incentives and the penalization and repression of vagrancy ${ }^{21}$. This resistance combined racial prejudice and disdain for Brazil's own free workers, seen as lazy, unreliable and lacking a modern (bourgeois, accumulative) mentality: they were satisfied with very little, meaning they could not be subjected or disciplined by financial incentives. Moreover much of the national population was 'coloured' - and 'men of

19 'How could men who planted enough to survive, who lived at their own devices and luck, be forced to submit, in exchange for scanty wages, to the arduous work demanded on the plantations? For them, working as wage-earners on the big estates meant assuming the condition of slaves' (Costa, 1999: p. 311).

${ }^{20}$ Cf., among others, Huggins (1985); Holloway (1997); Vellasco (2004); RusselWood (1999).

${ }^{21}$ Cf. the debates transcribed in Azevedo (1987, especially pp. 125ff). Also see Dean (1971: pp. 95-124). 
colour,' so the São Paulo elite imagined, could only be subjugated through brute force and lashings. It seemed unthinkable to try to incorporate them into the labour market voluntarily. Here we can cite a revealing letter from the councillor Paula Souza, transcribed by Florestan Fernandes in his classic text on the integration of blacks into class society (Fernandes, 1978: pp. 31-33), where Paula Souza suggests to his correspondent that the freed black population worked in just the same way as they had when slaves, simply because 'they need to live and feed themselves and, therefore, to work, something that they quickly comprehend [after being freed]'. Presumed in this argument is the idea - clearly shared by the letter's recipient - that the only way to extract labour from this 'brute' was by force, given that he seemed genetically inclined towards indolence and vagrancy. The councillor, who had quickly learnt how the free labour market functioned, knew that hunger was the best antidote for any atavistic slothful tendencies ${ }^{22}$.

The prejudiced perception of the letter's recipient stemmed from the second consequence of the inertia of the previous system: the degradation of manual labour by slavery ${ }^{23}$. For many centuries the rational, legal and theological justification for the captivity of African blacks was their indelible impurity, their barbarous, pagan and thus heretical customs, their inferiority, opacity and frightening alterity ${ }^{24}$. In this aspect - and this only the New World slave had the same status as the Greek or Roman

${ }^{22}$ In the words of one foreign observer already in the $20^{\text {th }}$ century: 'The negro is indolent; work inspires him with a profound horror; he will allow himself to be driven to it only by hunger or by thirst' (Denis, 1911, cited in Andrews1988, p. 515).

23 ' $[\mathrm{F}]$ or the whites, work, especially manual work, was seen as the obligation of negroes, of slaves … The idea of work carried with it a suggestion of degradation' (Costa 1982 [1966]: p. xi).

${ }^{24}$ On the process of transforming the opaque other into a monstrous 'alien' whose identity was thereby inaccessible, see Kearney (2003). Schwarcz (1987) provides an ingenious argument on the late $19^{\text {th }}$ century press' construction of the 'Brazilian negro' as 'violent and degenerate' and later as 'strange' and 'foreign'. 
slave in Hegel's famous formulation: he recognized his master as such because of the master's freedom and individuality (as a being-for-itself), but the master did not recognize the slave in the same way; since the slave was a thing, a natural entity, a beingin-itself and thus incapable of freedom (or self-consciousness), his identity (as an alterity) was inaccessible to the master. In the ancient world, however, enslavement derived from a fight in which one of the opponents (the winner) placed his liberty above all else, while the other (the loser) desired above all life and was therefore disposed to relinquish his own freedom. For Hegel, the subjection of the slave, though resulting from the imbalance of forces between the two opponents, had an undeniable aspect of consent insofar as the desire of the weaker rival for life (or selfpreservation) persuaded him to submit to the other rival who wanted freedom, something he could ensure by being stronger (Hegel, 1992: pp. 126-34).

In modern slavery, the dialectic of slave-based domination cannot be read as anything more than a metaphor. Clearly the slave defines the master, in the sense that the latter would not be free without the existence of the former. Neither would his identity as a master be tangible (in the sense of being true) without his ownership of the other's body as a capacity to manipulate and transform nature, from which the master, for this very reason, distanced himself, interposing between himself and things (nature) the subjugated desire of the other, objectivized in turn. And consequently the master's freedom immediately becomes subordinated to the thingness of the slave without which his access to nature (in other words, his material survival) would be impossible. The master is condemned to - or is a slave to - his slave. But here the immanence of the process ceases for at least three reasons.

Firstly, in the New World the warfare that opposed the desires of the two agents did not place them in direct 
confrontation. The slave was captured in a distant land by an intermediary with whom the future owner related through the mediation of the market. For the slave, the 'master' is an abstract entity who changes face as he is forced to leave his tribe, forced to embark on a slave boat where his life is constantly at risk, forced to accept his sale in public and to be sent to perhaps his final proprietor. 'Prefer life', in this case, is materialized in the slave's constant confrontation with the other who needs to affirm his physical superiority, his unequal resources, his desire to subject the slave not to appropriate the result of his manipulation of nature, but to appropriate the slave himself as merchandise. The slave trader is not Hegel's master except in a highly metaphoric sense, and the metaphor, in this case, provides no insight into the actual relation of subjection involved. The trader (or his future overseer) is nothing more than raw violence, immediately dehumanizing both agents, master and slave.

Secondly, the war of subjection of the slave does not take place once and for all, and nor does the slave 'consent' once and for all. The relation of subjugation must be reimposed every day by each new master, especially by the final recipient of the 'merchandise', who has to maintain whole groups of slaves. Here too the Hegelian dialectic of consensual subordination cannot be read as anything more than a metaphor. The modern slave does not choose life, since slavery is simply a death sentence, albeit one carried out over a longer period than those who end up on the gallows. As Schwartz demonstrated, a Bahian slave who survived ten years on a farm with forty slaves would see the entire cohort die out, not infrequently through suicide, and be replaced (Schwartz, 1995). The master needed the collective slave, but could do without the person of each slave in particular.

Here is revealed the tyrannical form of slavocratic domination in the New World and especially in Brazil where slavery was especially bloody and predatory: the master could take 
any decision in relation to his slave's life according to his whim. If he believed that a slave posed a threat to him, he could order his feet to be cut off, blind him, have him lashed or kill him. The master/slave relation was not a pact: the master was not obliged to preserve the life of his individual slave; much the opposite, his freedom to take the life of the other he had objectivized defined his position of master, even more so since the flux of slaves on the market allowed him to replace the entire cohort as he wished. In Brazil slavery meant not just the negation of the slave as a person (his objectification) but his negation as a living being. Here we are talking about centuries of horror during which slavery, ruining the black bodies of the captives and corrupting the minds of their owners, needed to be re-imposed day after day with an ever renewed violence, continually annulling one of the poles of the Hegelian dialectic, which therefore needed to be constantly replaced. Long-term slavery ended up abstracting the slave's face, depersonalizing him and objectivizing him in a repeated and permanent form. In the end only his colour remained, definitively associated with hard and degrading labour.

Finally, the Hegelian metaphor fails to take into account that the search for black Africans as an enslaved workforce was already predicated on the idea that they were not human. In this sense, black people were not turned into things by slavery. The Portuguese, Spanish, Dutch, British and French already saw Africans as barbaric beings from the outset, slaves to necessity and thus objects, their individuality completely opaque. From there transforming the captives into merchandise was a simple step, one which de-territorialized them without interfering in their essence as things - but which could 'save their souls' by ripping them out of the pagan universe in which they lived ${ }^{25}$.

25 A view shared by the Jesuit jurist Alonso de Sandoval, the priest Antônio Vieira, the 'humanist' Maurício de Nassau and by many others in the $17^{\text {th }}$ century (cf. Alencastro, 2000, especially chap. 5). Even radical abolitionists like Joaquim 
Consequently, the ex-ante degradation of the black African degraded the work that he, as a thing, executed. The long duration of slavery, whose predatory aspect depersonalized the captive, led to an image of manual labour as something unworthy of anyone who was not black, who, though 'atavistically inclined to avoid work' due to his 'barbarity' and 'foul blood,' could be persuaded only by force ${ }^{26}$. The image of work and the worker consolidated during slavery was produced, therefore, from the overlapping hierarchies of colour, social status associated with property, and material and symbolic domination in a mixture of meanings that converged on the perception of manual labour as something degrading ${ }^{27}$. More emphatically, the work ethic derived from slavery was an ethic of devaluing work, and rescuing it from the lingering traces of impurity and degradation would take many more decades ${ }^{28}$.

Nabuco (1999: pp. 142-45) saw the African as a blemish left on the face of Brazilian nationality by the Portuguese.

26 'For more than three centuries [the population of the Brazilian interior] was accustomed to seeing rural labour as something fit merely for slaves. For this population, almost all of which had emerged from slavery, freely declining the kind of work forced on slaves increased the distance between themselves and the latter.' (Nabuco, 1999: pp. 164-65).

${ }^{27}$ On the view of the national worker by landowners from various regions as incapable, lazy, indolent, and therefore unsuited to work, see Eisenberg (1999) and Eisenberg (1974: pp. 194-98). On the perception of the São Paulo elite, see Dean (1971); Azevedo (1987).

${ }^{28}$ Something similar occurred in France in the first half of the $19^{\text {th }}$ century where industrial work was seen, for example, as 'corrupting of the mental faculties,' as declared in the Dictionnaire d'économie politique [1891-92] by Léon Say \& Joseph Chailley, cited by Castel (1998: p. 288) amid other evaluations of the working class ('barbarians,' 'vile multitude'...) which, the latter author argues, amounted to an 'anti-working class racism widespread [among] the $19^{\text {th }}$ century bourgeoisie.' Consequently the workers movement asserted from its outset 'the dignity of manual labour and its social pre-eminence as the true creator of wealth' as decisive aspects in the construction of class identity (ibid., p. 443; also see Thompson, 1987: vol 2). The same phenomenon occurred in Brazil at the beginning of the $20^{\text {th }}$ century, as shown, among others, by Moraes Filho (1952), Dias (1962), Fausto (1977), and Hall and Pinheiro (1981, vol. II). 
The third important consequence of the slow transition to free labour, closely connected to the previous two, is that the apparatus of financing, reproducing, supervising and repressing slave labour, highly decentralized and with lose control from the Portuguese and later Brazilian Empire, consolidated a pattern of state and private violence that outlasted the end of slavery. This violence was transferred to various dimensions of the relationship between the State and the 'world of work'. In fact the process of consolidating the forces of repression and administering justice in colonial Brazil and well into the $19^{\text {th }}$ century granted considerable leeway to powerful local figures to suppress and punish acts considered deviant. Both Oliveira Vianna and Gilberto Freyre called attention to this problem. In the patriarchal Brazilian system, the owner of a sugar plantation or a large landowner had the power of life and death over his family and slaves. The authors argue that the dispersal of rural estates across the vast national territory, along with their relative autonomy in terms of self-sufficiency, made any attempt at coordinating a centralized police force extremely difficult. This reduced the economic exchanges between them, and neither encouraged the interdependence of the economic agents nor made them dependent on the vicissitudes of politics, which equally distanced them from the State's affairs. As a consequence, any intervention by police forces in the master/slave relationship was seen as undue interference by public authorities ${ }^{29}$.

Some aspects of this interpretation have been qualified by more rigorous historiographic research, which has shown, for example, that the sugar plantation owners in Pernambuco were also federal deputies, governors, mayors and high-level administrators in the State machine, including the police force; that the São Paulo legislators who opted to promote foreign

${ }^{29}$ As clearly demonstrated by Franco (1976). 
immigration were for the most part landowners; and that even the university-educated administrators of the Empire in Rio de Janeiro came from the rural elite in their home provinces ${ }^{30}$. Hence the State's affairs were not indifferent to the big landowners, but the principle was the same: social relations until the end of the $19^{\text {th }}$ century (with legacies evident in the $20^{\text {th }}$ century) were marked by privatization of the mechanisms of social control, a process in which the State functioned as an accessory of the slave owner in the task of disciplining his 'merchandise'. This practice can be traced in part to the Portuguese tradition of social control, based on civil militias capable of being mobilized at any moment by homens de bem, 'good men', in the name of the Crown. This delegation of power was how the latter made itself present across the imperial territory, thereby granting huge autonomy and decision-making powers to powerful landowners (Costa, 2005).

The re-organization of social control in the $19^{\text {th }}$ century maintained these prerogatives, as shown in the context of Rio de Janeiro by the existence of the Calabouço, the 'Dungeon', a jail where guards whipped the slaves taken there expressly for this purpose by their owners. At least until the 1830s the owner had no need to prove that his captive had committed an offence: he simply sent the 'delinquent' to the prison with instructions for the number of lashes to be given (usually two hundred strokes), thereby exempting himself and his family from witnessing the torture, which very often led to the 'condemned' slave's death (Holloway, 1997; Karasch, 1987). The Calabouço lasted until the 1870s, carrying out this same function among others. According to Holloway, in Rio de Janeiro at the start of the $19^{\text {th }}$ century,

30 Cf., respectively, Eisenberg (1974); Dean (1977), and Azevedo (1987). See also Carvalho (1980). 
the police functioned as a state-sponsored extension of the control of the owner class over people who were their property. The police grew accustomed to treating slaves and the free lower classes in similar ways, and as the proportion of slaves in the population declined after mid-century, the attitudes and practices of the system of repression were transferred smoothly to the nonslave lower classes, and persisted (Holloway, 1997: p. 215).

There is no reason to suppose that the pattern prevailing in the Empire's capital would not have been reproduced in other urban settings ${ }^{31}$, let alone $r$ ural enclaves. On the other hand - and this aspect is of decisive importance - the virtual absence of external conflicts that would have required a fullscale professional army to protect Brazil's frontiers meant that the embryo of a national armed force that emerged in the $19^{\text {th }}$ century ended up working alongside the local militias to identify and suppress internal enemies. True, the working classes have been seen as dangerous throughout the world and during various moments of Western history (Chevalier 1984 [1958]). The massacre in Peterloo, Manchester, in 1819 (Thompson, 1989, vol. III: pp. 256ff), the bloody suppression of the working classes during the 'June Days Uprising' of 1848 in Paris (Tocqueville, 1991; Marx, 2012), and Bloody Sunday in St. Petersburg in 1905 are all examples of the exorbitant action of the forces of law and order in repressing movements with very often peaceful intentions (as in the case of Peterloo and St. Petersburg), a fact

\footnotetext{
31 On the São Paulo case, see Fausto (1984). Citing the description by a police chief of a young woman of 20 years, accused of stealing in 1892 - 'She was a black woman of average height, frizzy hair, large eyes, good teeth, thick lips' - therefore using a terminology typical of the slave market, the author asks: 'A simple vestige of an old habit still existing in the years immediately after Abolition and on the way to vanishing? Nothing suggests this' (p.54). Also see Pinto (1994). On the Bahian case, see Fraga Filho (2006).
} 
that illustrates the immense fear of the dominant classes vis-àvis the dispossessed majority.

In Brazil the view of the slave as a potential collective enemy worsened in the imagination of the elites after the Haitian revolution of 1804 , which freed the country from the French colonizers by massacring them cruelly. The fear of a catastrophic slave rebellion that could overturn European-style 'civilization' became more pronounced from 1835 onwards with the Muslim Uprising in Bahia (Reis, 2003), the culmination of a series of clashes and uprisings that helped spread the idea of the aggressiveness of the slaves, keeping their owners in a state of permanent tension ${ }^{32}$. The ferocity of the punishments inflicted on captives in Brazil may have stemmed in part from this consummate fear ${ }^{33}$, incited more by imaginary threats than real ones. In the case of São Paulo, the end of the Atlantic slave trade in 1850 and the importation of slaves from other Brazilian provinces, especially the Northeast, meant that the perception of the internal enemy was even more decisive in terms of determining the form of suppression of black rebellion, with private and state forces combining to react with extreme violence to the slightest display of slave resistance ${ }^{34}$. As Florestan Fernandes astutely observed,

${ }^{32}$ In $18^{\text {th }}$ century Minas Gerais it was common for slaves to bear arms in defence of the Crown's interests, as Costa (2005), for example in this passage: 'In 1719, fearing acts of sedition on the part of the black population of the captaincy, [the count of Assumar] informed the king that the climate of tension was worsening because the 'negroes' had in their favour 'their multitude and the foolish trust of their masters, who not only entrusted them with weapons of all kinds, but also covered up their insolences and crimes" (pp. 495- 96). The idea of the threatening black 'multitude' is synonymous with the 'black wave' of the second half of the $19^{\text {th }}$ century studied by Azevedo (1987).

${ }^{33}$ While in the south of the United States the number of lashes for 'misdeeds' never exceeded 25, in Brazil it was common to torture captives with two hundred or more strokes, very often administered by other slaves.

${ }^{34}$ Examples can be found in Dean (1977); Azevedo (1987); Schwartz (1995); Carvalho (1987); Machado (1994). 
in the slavocratic society the prevailing wisdom was to prevent any flourishing of organized social life among the slaves and former slaves because of the constant fear of the 'black rebellion'. As Perdigão Malheiros wrote [in 1866], the slave appeared like 'a domestic enemy', 'a public enemy': 'he is the volcano that continually threatens society, the landmine ready to explode with the slightest spark' (Fernandes, 1978, vol. 1: pp56-57).

During the Vaccine Revolt of 1904 in Rio de Janeiro, the state repression largely reproduced the pattern of the exacerbated knee-jerk responses instilled in the dominant classes decades earlier by the fear of a slave rebellion. José Murilo de Carvalho points out that in Brazil at the time,

in the case of popular revolts, the bulk of the prisoners were never taken to court. Only the leaders were tried, very often members of the elite. The rest were simply placed in ships and banished to some remote point. They didn't even pass through the Detention House where their personal information would have been recorded (Carvalho, 1987: p. 113).

In the case of the 1904 revolt, we are talking about hundreds of people exiled without trial or any production of proof. The other thousands of rebels were not recognized to have taken part in the crisis voluntarily, the elites preferring to label them as merely rash, manipulated by the 'disorderly' and 'disqualified' - a view shared by luminaries such as Rui Barbosa, Olavo Bilac and many others ${ }^{35}$.

At the end of the $19^{\text {th }}$ century the fear of the unknown hordes still persisted in the minds of the São Paulo elites. In

${ }^{35}$ Cf. Carvalho (1987: p. 115). Also see Sevcenko (1984); Pinheiro (1991); Bretas (1997); Misse (1999). 
1893 Siqueira Campos, the São Paulo Justice Secretary, told the State President, Bernardino de Campos, that the cause for this feeling of insecurity experienced by Paulistas was perhaps 'the growth of the population and principally [...] the increase in a fluctuating population hidden from view that renews itself from one moment to the next ${ }^{36}$. The fear, then as now, was fear of the unknown, of that which could not be controlled or dominated because it was not submitted to the traditional forms of domination. This was the fear of the opaque other, anonymous, containable only through brutal and indiscriminate repression ${ }^{37}$.

Siqueira Campos also asserted that this feeling of fear and insecurity jarred with the 'general physiognomy of our people ${ }^{38}$, which, he claimed, was peaceful. This viewpoint announces the fourth consequence of the slow transition to free labour: in the context of the social relations between capitalists and workers at the start of industrialization the idea persisted, among the economic elites, of the Brazilian worker as 'peaceful', 'orderly' or 'cordial,' in opposition to the immigrants, bearers of alien ideologies such as anarchism and communism. The notion of the 'peaceful' Brazilian pertains to the same semantic field as the idea that slavery in the country had been 'benign', to cite Gilberto Freyre's classic formulation in Casa-grande \&o senzala (Freyre, 1994 [1933]). Both notions presume subaltern classes who 'know their place', which consequently legitimizes (private and state) repression and violence when these same classes rebel or assert their autonomy.

\footnotetext{
${ }^{36}$ Cited in Santos (2005: p. 35).

${ }^{37}$ On this point it is notable that throughout almost the entire First Republic when anarchists, socialists, strikers, feminists, union leaders and the like were imprisoned they were indiscriminately recorded as offenders and, therefore, as public enemies (cf. Fausto, 1984: p. 34).

38 Cited in Santos (2005: p. 35).
} 
The idea of 'benign' slavery had first been cultivated in the $19^{\text {th }}$ century and owed much to the work of travellers like Auguste de Saint-Hilaire, Henry Koster and John Luccock whose books frequently contained favourable assessments of the treatment of slaves in Brazil (Versiani, 2000). These opinions deeply influenced the work of Gilberto Freyre, who in turn left his mark in much of what was written about slavery in Brazil in the 1940s and 50s, especially by American investigators interested in Brazil's 'racial democracy' ${ }^{39}$. Freyre attributed the structural benevolence of the Brazilian slave owner to the charitableness of Portuguese Catholicism and the Moorish (or Arabian) influence on the way in which the colonial family was organized, contrasting these with the American slavocrats, for example ${ }^{40}$. True, Freyre did not ignore what he called the 'sadistic' attitude of some sugar plantation owners, the result of an arrangement in which violence was always ready to surface as part of the control and submission of captives. For Freyre, the 'sadism of power' sustained the 'conservative tradition in Brazil' (Freyre, 1994: p.52), placing it at the centre of the equilibrium in Brazilian political life, but cruelty against slaves was an exception, not the rule, and was mostly absent from the casa-grande (the plantation house system identified as the ideal type of Brazilian social order by the author), though it was sometimes necessary in the treatment of captives working the land.

This image was contested from birth by abolitionists of various kinds as an anti-abolitionist propaganda of the Empire

\footnotetext{
${ }^{39}$ Frank Tannenbaum, in his classic Slave and citizen (Boston: Beacon Press, 1946), was decisively influenced by Freyre's ideas, identifying miscegenation and the mulato's possibility of social mobility (the Freyrian explanation for the success of Brazil's 'racial democracy') as a potential solution to the American racial dilemma.

${ }^{40}$ On Freyre’s study, see Araújo (2005).
} 
intended to 'spread a rosy picture of the situation of the slaves ${ }^{31}$ and use this to justify captivity. Moreover the ideology of 'benignity' was linked to the fear of a slave rebellion similar to what had happened in Haiti and to the growing rebelliousness of the slaves in the second half of the $19^{\text {th }}$ century (Azevedo, 1987; Moura, 1981). In other words, neither was slavery benign, nor were the slaves peaceful or submissive, but, as far as the dominant ideology was concerned, passivity was the most common description applied. In fact the Empire's elite, especially in the big cities, perceived day-to-day violence as deviant conduct by degenerate and barbaric individuals, lost to civilization (Holloway, 1997).

The orderly nature of the Brazilian population has been praised at various moments of the country's history, remote or recent ${ }^{42}$, and provides the basis to the argument, promulgated by many thinkers of the time, that the transition to free labour took place in a mostly atraumatic form in contrast to events in the United States or Haiti, for example. In the first decades of the $20^{\text {th }}$ century the nascent Brazilian sociology saw the peaceful nature of the country's people as a defining element in Brazilian nationality, with deep roots in the previous socioeconomic system, marked by familyism, individualism and patrimonialism - that is, the country's Iberic inheritance, averse to open conflicts and above all to collective action. These ideas are equally present in Sérgio Buarque de Holanda, Oliveira Vianna or Gilberto Freyre, albeit interconnected in distinct forms in each author and treated with varying degrees of critical distance. In this view,

\footnotetext{
${ }^{41}$ See Versiani (2000: p. 7). The author cites Conrad's text (op. cit.), arguing that the idea of benignity had first originated in a publicity campaign run by the Brazilian government.

${ }^{42}$ In 1831, after quelling a mutiny of Republican soldiers, Regent Feijó claimed that 'the Brazilian was not made for disorder, his natural state is tranquillity and he aspires to nothing more than the sworn Constitution, the enjoyment of his rights and freedoms' (cited in Patto, 1999: p. 171).
} 
collective action appears as a corruption of the natural order of things, marked by the individual subjection of subalterns to a powerful local figure that would control everyone's destiny.

The alien element brought to the country by European immigration - foreign but white and therefore civilized - was absorbed into the same worldview, appearing as a bearer of ideas with no place in Brazil's social reality since they had been gestated in a disturbed environment steeped in class struggle, opposed to the spirit of conciliation supposedly reigning in the new country. The foreigner with socialist or anarchist ideas became an even more dangerous other than the slave since he could contaminate hearts and minds with ideas capable of transforming the very structure of traditional domination. The slave was feared for his difference and above all his opacity, which provoked the fear of a black uprising capable of ending civilization. The fear of the European socialists and anarchists went further. They did not want the end of civilization, but a model of civilization that included them in a non-subordinate or egalitarian form. Their proselytism could show the peaceful and orderly Brazilians that their position in the social hierarchy was unjust and that the system was therefore illegitimate. It could transform the people into the internal enemy formerly represented by the slave in the minds of the elites.

This led, then, to the transposition of the symbolic imagery surrounding slavery to the capitalist order: the people were only of interest qua a set of individuals resigned to their position in the social hierarchy, which rewarded each person as long as each person recognized the other who provides the reward as someone with authority over him or herself. The fear of collective action from the people, incited by alien elements (immigrants), is the functional equivalent of the fear of the slave rebellion. The slow modernization of Brazilian society at the start of the $20^{\text {th }}$ century and its gradual corrosion of traditional structures of domination 
failed to dilute this fear. Instead it acquired new forms and new meanings ${ }^{43}$, among which anti-communism was perhaps the most important, as Motta suggests (Motta 2002).

Here it is worth mentioning briefly a final consequence of the longevity of slavery, which relates to workers' expectations for their quality of life. Antonio Candido was the first to draw attention to the social indifferentiation found in São Paulo rural communities at the start of the $20^{\text {th }}$ century, the result of an incipient social division of labour and a general lack of resources, meaning that members of these communities kept themselves alive with no more than the 'bare minimum' (minimos vitais) (Candido, 1964). This situation led Maria Sylvia de Carvalho Franco to develop an ingenious argument to explain the violent nature of the sociability among free men under the slavery regime. She proposes that the need for supplementary relations between people living in poverty under equal terms in rural localities with a high nomadic fluidity - a context where the 'ancient and unbreakable reciprocal obligations were not consolidated' (Franco, 1976: p. 31), nor principles of authority constructed on the basis of a hierarchy of functions - led to a simplification of inter-human adjustment mechanisms founded on bravery and the banalization of violence. The author continues in a lengthy but crucial passage:

Without ties, simple, [the rural groups] belonged nowhere and blended in everywhere. It was also this same marginalization that kept the social system simple, ordaining basic functions beyond the confines of the group. Here it is worth us recalling that the soldier, priest and public authority were always associated with institutions alien to the rural world. The staggering poverty of the culture derives from the same source. It suffices to point

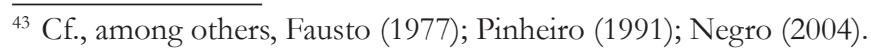


out how 'colonial' production favoured the enormous wastage of the workforce, a characteristic of these groups. This was the context in which the 'lazy' rural worker was born, placed in the happy situation of almost 'not needing to work', with the social organization and culture adapting to ensure him ample time for leisure, but who simultaneously suffered the miserable situation of only being able to produce the bare minimum necessary to ensure survival (Franco, 1976: pp. 32-33).

Two aspects of this argument interest me. Firstly the idea that sociability during the slavocratic regime was astonishingly fluid, in the sense that the free rural population was largely removed from local ties of domination and lived constantly in search of precarious means of survival across Brazil's vast territory. In this sense, slavery generated a paradox: the social hierarchy was pronounced and extremely rigid at its higher levels but fairly malleable at its base where poverty made everyone equal ${ }^{44}$. Secondly and more importantly the slave-based society made the free person a pariah in an ample sense, including his/ her expectations for standard of life. These were the same for everyone, with people's expectations for the future defined by the existence of slave labour. The free person (white or not) was distinguished from the slave only by the fact that he or she was no one else's property: otherwise he or she was very similar to the slave in terms of diet, clothing, residence, life expectancy at birth, and so $\mathrm{on}^{45}$. In this context, people's expectations were limited to the bare minimum needed to live as established by the contemporary standard of measurement for the entire system: the exploitation of the slave workforce. This partly explains why the free workers were not easily expropriated or forced into

\footnotetext{
${ }^{44}$ On the Campinas region, see Moura (1998); on the Bahian Recôncavo, see Schwartz (1995); Fraga Filho (2006).

45 As Costa (1982 [1966]), long before Franco.
} 
exhausting labour, since they had an alternative to submitting to the kind of work degraded by slavery. Although this alternative remained at the most basic subsistence level, it was accepted as natural given the overall poverty of the society.

In the case of São Paulo, this situation was fatally wounded by the first fluxes of immigrants. The local population was placed in the awkward situation of being treated as a contingent of second-class citizens compared to the Italian immigrants, who arrived with 'privileges' such as access to a plot of land for their own cultivation. But this did not happen in the other provinces of the Empire, where the socioeconomic conditions remained much the same over a long period, passing on to future generations the low levels of aspiration, confronted each step of the way by scarcity and poverty, which severely restricted the horizon of possibilities of the entire social order. Men and women were not slaves insofar as they were no longer someone else's property, but they continued to be 'slaves to necessity', which also comprised the cultural horizon in which their life aspirations and projects were determined ${ }^{46}$. The end of slavery failed to change this framework: amid the generalized poverty in the rural world and the inaccessibility of higher social positions, barred by the rigid social hierarchy, expectations for improving the quality of life remained quashed for several decades, only growing with the intensification of industrialization in the second half of the $20^{\text {th }}$ century.

By way of conclusion we can propose, therefore, that this framework of structural inertia shaped the environment in

${ }^{46}$ For a dense analysis of the construction of the taste and aspirations of workers, shaped by living in close proximity with necessity, see Bourdieu (1979). 
which capitalist sociability developed in Brazil. This means that the revolutionary nature of capitalism had to converge with a social order that was highly rigid in terms of its practices and its symbolic imagery - much more rigid than the traditional literature on the subject was willing to recognize. This rigidity was manifested in the disqualification of the black and national population as workers capable of undertaking capitalist work; in the perception of manual labour as a degrading activity, conceivable only for degraded beings; in the fortification of the economic elite in their positions of power, fearful of the dispossessed (and unarmed) majority, seen as potential enemies and treated with excessive violence whenever they asserted themselves in public; in the persistence of a structure of domination that reduced to the bare minimum the financial expectations of the poorest in a context where generalized poverty was the parameter for everyone. In sum, capitalist sociability had to engage with a profoundly anti-liberal order in terms of its practices and worldviews ${ }^{47}$ and with an ethic of devaluing work that for a long time prevented recognition of workers as subjects with rights - that is, as citizens ${ }^{48}$.

\footnotetext{
47 As Schwarz (1981: pp.16-18) suggested, liberalism was an 'idea out of place', since favours and personal dependence, not the market, mediated social relations.

${ }^{48}$ Getúlio Vargas constructed the myth of the 'father of the poor' against this background. The propagandists of the Estado Novo attributed to Vargas (and to the 'gift' of the labour rights) the de facto end of slavery, forty years after its legal abolition. See Gomes (2006). In Chapter II I will analyse this in depth.
} 


\section{CHAPTER II \\ A BRAZILIAN UTOPIA: \\ Getúlio VARGas AND the CONSTRUCtion OF THE Welfare State in a structurally \\ UNEQUAL SOCIETY ${ }^{1}$}

Getúlio was everything for our people, be was everything for the people in agriculture. [...] Before Getulio there was no law, we were animals. Princess Isabel only signed [the law abolishing slavery], it was Getúlio who freed us from the yoke of slavery. (Cornélio Cancino, a descendant of slaves, in a testimony to the project 'Memoirs of Slavery', cited by Rios and Mattos, 2005:56)

\section{Introduction}

A persistent Brazilian inequality continues to challenge the sociological imagination, and rightly so. In 1872 the Gini coefficient, one of the possible measures of inequality in income distribution, may have been 0.56 , according to recent estimates ${ }^{2}$.

1 Translated by Paul Freston from DADOS - Revista de Ciências Sociais, Vol. 53, No. 4, pp. 775-819, 2010, for the Scielo Social Sciences (http://socialsciences. scielo.org/scielo.php?script=sci_arttext\&pid=S0011-52582010000100006).

2 The Gini coefficient is the most commonly used measure of income inequality in a specific population. It varies from 0 to 1 , where 0 means that each person in the population gets the same income as everybody else, and 1 means that one 
Almost fifty years later (1920) the coefficient seems to have worsened, reaching $0.62^{3}$. In 1976, another fifty or so years later, the number was the same: 0.62 . And in 2006 the coefficient was 0.57 , equivalent to that of 130 years before. This disconcerting and long-lasting dance of the numbers counsels caution to those who study the subject in search of a clear causality restricted to recent events. Over the past 130 years Brazil has transitioned from a slave agrarian economy to one of the most important industrialized societies in the world. This structural shift did not lead to a more egalitarian society - or even to a society in which most people were no longer poor or restricted in their freedom by social exclusion and poverty -, as one would expect from similar modernizing processes.

This chapter seeks to contribute modestly to the current and persistent effort at deciphering the enigma of Brazil's persistent inequality. The Brazilian sociology of work will be used here as an initial tool of interpretation. I then propose a revision of what is known as the 'Vargas Era' - its historical significance and scope -, analysing the reproduction of inequalities over time. In the first place, I present the parameters for interpreting modern Brazil which were proposed by Juarez Brandão Lopes in the 1960s, as well as the most important spinoffs from the debate which followed his empirical studies with

person gets all the available income. Thus, the closer the coefficient is to 1 , the more concentrated the total distribution of income is for a given population. It has already been demonstrated that in countries with high income inequality Gini is not the best measure, since it does not capture the extremeness of the distribution. Moreover, the coefficient is a very limited measure of inequality since this can manifest itself in multiple dimensions that go beyond income. The objective here is only to show that it has always been very unequal in Brazil, and that the pattern of inequality is persistent over time.

3 The 1872 and 1920 coefficients were calculated by Bértola et alii. (2009) in a preliminary study, therefore the numbers must be analysed with caution. The 1976 and 2006 numbers are available at http://www.ipeadata.gov.br and are reliable (accessed in September 2009). 
factory workers in the states of Minas Gerais and São Paulo. I suggest that if read in an unbiased way and in consonance with the findings of the most recent historiography produced in the country, this interpretative corpus has great explanatory power for the dynamics of Brazilian inequality, far beyond that envisaged by its original authors. After that, I analyse selected aspects of the Vargas project of 'integral advancement of the Brazilian man', in order to direct attention to its limits and its consequences in the reproduction of inequality over time. I argue that the state's structural poverty was one of the factors responsible for undermining from the outset the possibilities of success of the Varguista endeavour. Nevertheless, the establishment of social and labour legislation fully changed the relationship of the Brazilian state with its people. I maintain that 'regulated citizenship' gave the workers the expectation of social protection, which fostered a promise of integration as citizens that, although it never became effective, finally fulfilled the task (but not permanently) of including workers as participants in the Brazilian process of state development. From Vargas onwards, Brazilians discovered that it was worth fighting for the effectiveness of the state as a judicial system that promised them protection and social welfare. In turn, this struggle shaped their social and political identity, since in a country with $80 \%$ of the population below the poverty line the promise of rights was a utopian promise. It was capable of competing very favourably for hearts and minds with other promises (such as the socialist or communist ones), because it was embodied in institutions and in the state judicial system, especially in its capacity to legitimately curb dissent. Since 'regulated citizenship' was a promise that was never made universal, it proved to be an important, multidimensional and institutionalized mechanism for the reproduction of inequalities. 


\section{'The adaptation of the worker to industry'}

Probably the study with the stronger impact on Brazilian sociology of work in the first half of the 1960s was a short article by Juarez Brandão Lopes, called 'The adaptation of the worker to industry: social mobility and motivation'. It was based on research carried out in 1957 and published in a book edited by B. Hutchinson in 1960 called Mobility and Work. The article was reprinted in 1964 in a watershed book: Industrial Society in Brazil. It is not hard to determine the impact of this article, and afterwards of the book, on the interpretation of the social world of work in Brazil, since much Brazilian literature of the 1960s and 1970s used it in one way or another as a reference. In what follows, I will retrieve this tradition in order to propose a more general reflection on the inclusion of workers in the dynamics of Brazilian capitalism. Then, I use evidence brought by Lopes himself - to which I add some more - to propose an alternative interpretation of the processes which he presents as aspects of the 'crisis of archaic Brazil'.

In the aforementioned text, Lopes adheres to the Weberian tradition (as interpreted by Parsons in the United States) and does a classic study of social change. He is interested in the behavioural adaptations required of rural migrant workers who transfer to industrial work. It is a process which generally blends social and geographical mobility. Therefore, it has an enormous capacity to affect the whole life of the people involved.

Lopes works with a solid set of assumptions, although they are not always explicit in his text. He believed Brazil was on the cusp of becoming an industrial society. Hence, it was essential for sociology to comprehend the mechanisms of this transformation, especially its impact on wage-earners in the cities or in the countryside. With a masterful command of the sociological literature, especially American work on industrialism 
and its social and organizational ills and dilemmas, Lopes was convinced that industrialization was inevitable and that it would forever transform Brazilian reality and the ways its population was included in the dynamics of capitalism.

His explanatory framework was simple and elegant, just like the theories of modernization. His starting point was an ideal type of traditional society, in which 'economic facts derive from a system of personal relations' (p. 25) ${ }^{4}$, and in which the fundamental principles that sustain trade are reciprocity and redistribution, not the free market. The origin of the explanation is Karl Polanyi and his idea that the economy of traditional societies is 'embedded in their social relations' (ibid.). In this society, work is assured by people's moral obligation to the community's norms of survival, on which their self-esteem, the fulfilment of their needs, and their individual survival depend.

This society is a counterpoint to the one in which the free market is the nucleus of the social and economic systems. 'Acquisitive activity is approved of; the social expectation is that people seek to achieve their individual economic interests. Economic behaviour [...] must be rational' (p. 27). The economic system is open, since each person seeks his own fulfilment, in contrast to the relative inwardness of traditional society; market price, not social norms, is the main factor coordinating these actions.

Thus, the research problem is already outlined: the migration of people from rural areas to the cities is the unmediated shift from an environment similar to traditional societies to one ruled by the rational free market economy. This leads to a problem in adapting expectations and patterns of behaviour, a problem characteristic of the beginnings of industrialization in Brazil and of the process of development of its working class.

4 In this analysis, I use the version of the text published in Lopes (1971:22-95). Quotes will have only the page number. 
To study this problem Lopes chose a medium-sized factory in the city of São Paulo in which only $7.5 \%$ of the workers were originally from that city. Another $28 \%$ were foreign and the remaining 63\% were internal migrants, $21 \%$ being from the Northeast. Because of the large contingent of North-easterners, Lopes briefly portrays the sociability typical of these workers' rural origins, to show that they did in fact come from a traditional type of society. And he argues that the rural migrants, especially those from the Northeast, believed in 'the cultural value of being self-employed, independent, reliant only on their own initiative, and not having to subject themselves directly to anyone' (p. 36). Moreover, few had the intention of staying in São Paulo. Their dream was to make some money and return to the countryside, where they had left their families. This pattern is only partly distinguishable from the migrants from the interior of the state of São Paulo, who would stay in the city 'if things worked out', but would go back if they did not (pp. 38-39).

From this point onwards, Lopes' work could be written as pure and simple deduction from modernization theories. After demonstrating that the North-eastern migrant ends up staying in the city - since working in a factory is, after all, easier than working in the fields, and the comparison between their current life, thought of as hard, and their earlier life, thought of as much harder and more insecure, is favourable to the city -, the author insists that '[the] psychological orientation of the interviewees from rural areas is clearly outside the industrial system' (pp. 4445) and that everyone's wish is 'to work for themselves', because then they would not be dependent on working-hours and a boss. But he then offers an interesting piece of evidence, from which he himself does not draw the obvious conclusions, but which would have a lasting impact on future Brazilian sociology. An interviewee from the state of Ceará tells him that 'a man who 
has to clock in has no future; a person who is self-employed can better himself (p. 46). Lopes sees this discourse as the supreme expression of the unadaptedness of the recently migrated rural worker to industrial society. And to this lack of adaptation he attributes the difficulty (or rather, the impossibility) of forming typical working class solidarity, such as developed in the classical model of industrial capitalism.

Maybe the most provocative alternative analysis of the consequences of Lopes' findings has been formulated by Alain Touraine, in a small but very influential text called 'Industrialization and working-class consciousness in São Paulo', published in 1961 in the journal Sociologie du Travail. Touraine makes reference to studies made by Lopes, Fernando Henrique Cardoso (who, in turn, based his study on Lopes) and to Florestan Fernandes' Social Changes in Brazil, to assert that the desire to improve one's life, contrary to what Lopes, Fernandes or Cardoso affirmed, is a conduct of mobility (p. 396) an expression of certain types of modern attitudes that form what he called 'consciousness of mobility'. Touraine agrees that the weight of pre-industrial traditions impedes these workers' identification with the working class. But, besides this weight, what is more important is 'the belief, which may be utopian, in the opportunities that urban life and industrial work offer; a desire for mobility that is not fulfilled by an unstable and unqualified job and that leads them to hope that one day they will overcome their present condition' (p. 396). According to Touraine, this consciousness of mobility holds many consequences for the social and political dynamics of the working class because it 'is accompanied by a relative integration of attitudes, in which the most frequent aspect may be utopian nonconformity, i.e., the combination

5 Pages refer to the original edition, Touraine (1961). 
of traditional submission with hope in the possibilities of betterment for the individual and, more than that, for his children' (p. 397). In this process, past and present are reinterpreted through the expectation of bettering one's life. And since this consciousness closely links individual mobility and the collective development of the country, the result is the legitimation of society as a whole, which consequently becomes protected against a revolutionary uprising.

Touraine adds other important arguments that are also taken on board by the subsequent debate, such as the idea that in Brazil urbanization preceded industrialization, and therefore industry was not the main destination of the rural masses. Moreover, this process led to the marginalization and poverty of large segments of workers, not to mention inequality and competition for the few vacancies in industry, contributing to the preservation of low wages, etc.

These studies by Lopes and Touraine strongly influenced subsequent research, although perhaps in ways not anticipated by the authors. Leôncio Martins Rodrigues, for example, in very influential research carried out in the factories of multinational automobile manufacturers ${ }^{6}$ which at the time were considered to be employing the most modern sector of the working class, discovered traditional working-class attitudes, consciousness of mobility, and aversion to industrial work, as well as the incapacity for collective action and the absence of class consciousness. Based on the same studies, Fernando Henrique Cardoso supported an even stronger idea in his 'The proletariat in Brazil: situation and social behaviour', originally published in 1962. In his opinion, rural workers left the countryside mostly to escape destitution, not to strive for social mobility (Cardoso, 1969:116), since they were more resigned to their fate and more willing to accept the

${ }_{6}$ Especially, Martins Rodrigues (1966 and 1970). 
precarious conditions of industrial work. Intense migration from countryside to cities, in a compressed period of time, 'produced a 'narcotic effect' on the level of consciousness of the situation [...] and accordingly on the possibility of presenting demands at the level of the company or of society as a whole' (p. 117). Because of this and the other reasons mentioned by Lopes and Touraine, this working class could hardly act according to their specific class interest, since they did not see 'the issue of power as the touchstone of a proletarian action historically conscious of its role' (p. 121).

Brazilian historiography would demolish these arguments in the 1980s. Since the foundational study of Paoli et al. (1983), the encounter of migrants with the world of industry ceased being treated as inauthentic because it did not lead to the revolutionary attitudes of a class 'conscious of its role' ${ }^{7}$. According to this interpretation, the working class in Brazil would be negatively defined by former studies: there was no class consciousness, it did not act politically to transform society, it was not modern, etc. It is impossible not to agree with this criticism. However, it seems that it should not be taken too far. In my opinion the aforementioned studies, although carrying the mark of inauthenticity identified by later studies, do bring elements that, when read through a different prism, reflect what actually happened in Brazil after 1930. I pointedly allude to what Touraine considers a 'utopian belief' in the possibilities of social mobility inaugurated by a changing Brazilian society. I suggest this is a powerful idea if read from a different perspective (i.e., if applied to the Vargas project of social integration based on the promise of 'regulated citizenship'). This is what we shall see below.

Also Paoli et al. (1983), besides Gomes (1988). 


\section{Aspects of a utopian construction}

The Varguista utopia acquired many interpreters during his first 15 years in power, but few were as systematic and incisive as Oliveira Vianna. His production is not vast, but it is very solid, especially the part devoted to advertising the accomplishments of the 1930 Revolution. I will analyse his conferences, essays, and newspaper articles between 1932 and 1940 (a period in which he directly participated in the administration of what he himself called 'revolutionary government'), which were later collected for publication (Vianna, 1951). In this extraordinary propaganda piece, we are exposed to the pinnacle of the ideology of the advancement of the 'Brazilian man' through the Revolution's social policies, which had finally come to redeem national identity from its four centuries of history. For Oliveira Vianna, the social achievements of Vargas had a corrective or purgative aspect in relation to the ills of a civilization which, through the hostile nature of the vast territory in which it flourished, had been consolidated without a frame or mechanisms which could foster social solidarity. In fact, Oliveira Vianna evaluates the Vargas government, of which he was also a part, through the prism of his own interpretation of Brazil as presented in seminal works such as Brazilian Political Institutions and especially Southern Populations of Brazil. According to this interpretation, until 1930 the people had been forgotten by the civilizing institutions. They had been abandoned to their own fate in an environment hostile to collective life, which forced them into an individual and submissive relationship to the private power of local caudilhos, masters of the scarce material and symbolic resources of community life.

The man without land, slaves, henchmen, wealth or prestige, feels that he is practically an outlaw. He has no support. 
No institution, whether in law, society or family, exists for his defence. Everything tends to make him historically disenchanted, an enduring unbeliever in his personal capacity to assert himself. [...] What four centuries of our evolution has taught him is that individual rights, liberty, the person, the home, the property of poor men, are only guaranteed, secured and defended when there is the support of the mighty arm of the local caudilho. This inner conviction of weakness, abandonment and incapacity is rooted in his consciousness with the depth and tenacity of instinct. (1922[1918]:151).

The eloquence of the formulation should not leave any doubts: cultural values and social attitudes and behaviour at the beginning of the 5th Brazilian century (as Oliveira Vianna liked to call the 20th century) were seen as a result of this heritage, rooted in Brazilians with the 'tenacity of instinct' and thus passed from one generation to the next through the centuries. But why did these abandoned people yield to local strongmen? Obviously through destitution, but also because these people were kind, forgiving, peaceable, 'full of Christian amiableness, generosity and gentleness' (Oliveira Vianna, 1951:58). The obvious consequence is that one should not have expected violent movements for the improvement of their own living conditions of life chances. Among Brazilians, despite its generally beneficial effects in creating social solidarity when resulting from a social dynamic different from the Brazilian one, those seeking to mobilise class struggle did not find fertile ground $^{8}$. To free the people from the yoke of local strongmen

\footnotetext{
8 In Populações Meridionais do Brasil (Southern Populations of Braz̧i), Oliveira Vianna sees a powerful agent of social solidarity in the class struggle, which is very 'efficient in the organization of Western peoples' (p. 157). Echoing Marx, he states that 'all of Greek evolution, all of Roman evolution, all of medieval evolution, all of modern evolution occurs under the prolific influence of the class struggle. These conflicts are extremely rare in our history [...]. They last for
} 
and elevate them to full citizenship was a civilizational task for the state, in which it did not have to 'battle against colour lines, class antagonisms or racial hatred' (ibidem: 56). It follows that the task of the Revolution, unlike in European countries, was not to secure social peace, which was already guaranteed by virtue of the people's character, but to promote social justice which had been hampered by the individualizing and degrading nature of our civilizational process.

Oliveira Vianna is advertising a piece of revolutionary engineering designed to integrate Brazil into this 'universal and incoercible movement, which is the policy of restoring the working masses to the possession and consciousness of their human nobility' (idem: 54). Not by chance, this plan's main word is inclusion. Having been excluded from the enjoyment of civilizational benefits, workers were included in three ways under Vargas: in the firm, through job stability which engendered mutual commitment between social classes for the welfare of some and the prosperity of others; in the state, through participation in trade unions as state agencies and in the corporative mechanisms of decision-making, which also embraced the upper classes; and in consumer society, a factor guaranteed by the establishment of a minimum wage (idem: 112ff) and social security, which he called a social property available to workers, ensuring material well-being to old people and to the sick and disabled. Therefore, workers supposedly had been bestowed with 'all the material and moral conditions of security and comfort, tranquillity and justice, independence and dignity' (idem:55-56), so that they 'feel the state's affection everywhere, the heedful action of its tutelage and its assistance'. However, it is important to point out that this

an extremely short period of time. They blossom in extremely limited areas'. They are not, therefore, promoters of solidarity. On the contrary, they lead to negative effects in relation to 'the political and social evolution of national identity' (1922: pp. 157-158). 
assistance was not like 'charity donations, which humiliated the ones being assisted', but like 'legal contributions, recognized, guaranteed and supplied by the state' (p. 50). The author has no doubt: the revolution brought 'legal security' to workers (p. 71). It also boosted the progressive improvement and dignity of the working classes in a capitalist society.

'However, this means that this improvement and dignity was not achieved through the suppression of social hierarchy, nor the elimination of the upper classes, nor the levelling of all of society's categories [...] but through the progressive sharing of advantages and benefits with which our civilization has been ensuring for over a century the comfort, well-being and human and social dignity of the upper classes' (p.106).

Nevertheless, in the same group of his own apologetic texts, Oliveira Vianna recognizes that the listing of contributions or services rendered by our institutions of social security and trade unions, represents a picture that does not always correspond to current facts' (1951: 127). He recognizes that social security is insufficient for subsistence, that medical and ambulance services are not up to what was promised, that the popular housing program for workers was hampered by credit problems, etc. But a 'fair judgment of these institutions' should not take into account their current limitations, but the 'formidable possibilities that they potentially contain' (idem: 128). Oliveira Vianna does not resign himself to the scarcity of resources in Brazil, which had led to the development of institutions incapable of fulfilling their promises, considering the huge needs of the people that the state wanted to elevate to citizenship. The legal design of these institutions was fair in itself, and its efficacy would be evident in the future, so workers should be patient. The structural limits 
to the effectiveness of this purgative work were thus seen as surmountable through the work of the state itself.

Vargas, especially during his dictatorship, was always conscious of the civilizational aspect of the labour legislation he had set up, but understood its limits in a country like Brazil more clearly than Oliveira Vianna. In 1941, in an ingenious speech delivered on Labour Day - the day which the dictator used to inform the workers about 'his' social projects, i.e., the new rights 'gifted' and added to the always incomplete structure of 'elevating the Brazilian man' -, he preached the virtue of fixing people in the countryside, though not necessarily through agrarian reform. Without this settlement Brazil would run the risk of "watching an exodus from the countryside and the overpopulation of the cities - an imbalance of unpredictable consequences that is capable of weakening or nullifying the effects of the campaign for the integral appreciation of the Brazilian man, aimed at providing him with economic strength, physical health, and productive energy'. He would also tell the thousands of workers that filled Vasco da Gama's stadium in Rio de Janeiro that:

We have to courageously face serious issues for the betterment of our population, so that we don't allow comfort, education, and hygiene to be the privilege of certain regions or zones. The benefits you have acquired should be extended to rural workers, to those secluded in the remote interior who are far away from the advantages of civilization. [...]

It is not possible for us to maintain the dangerous anomaly of peasants without their own land in a country where rich valleys like the Amazon remain uncultivated and vast pastures are without livestock, such as those in Goiás and Mato Grosso. For public wealth, it is necessary for the level of prosperity of 
the rural population to increase, in order to absorb growing industrial production; it is vital that we raise the purchasing power of all Brazilians - which may occur by raising the yields on agriculture (Vargas, 1941:261-262).

As one can see, Vargas had a clear idea of the structural demands facing his civilizational project. Brazil was a rural country, with slightly less than $3 \%$ of landholders, even though $70 \%$ of Brazilians lived in the countryside, one-third of whom were wage earners and two-thirds of whom were in various relationships such as tenant farming, sharecropping, smallholding or freeholding. Most were willing to depart at the slightest sign that life might be better somewhere else. It would not be possible to have the rural population settled if the benefits of civilization ushered in by the Revolution in the cities were not extended to them.

Furthermore, a strong rural world would form the domestic market for the emerging industrial output, and therefore the project could only be the colonization of Amazonia. Unable to confront the problem of land ownership in a country still hostage to agrarian oligarchies (another important restriction on his transformative project), Vargas thought the expansion of the agricultural frontier, the occupation of Amazonia and of uninhabited land subject to public policies of settlement was the only alternative ${ }^{9}$. Hence, it was necessary to establish policies that did not affect the consolidated agrarian structure of the rest

9 In an example that this might actually be possible, Japan invaded Malaysia in 1943, to where Amazonian rubber tree seeds had been pirated at the end of the 19th century, ending the Brazilian monopoly in latex. The Japanese invasion provoked a sudden dearth of the raw material, and the rubber latex extraction of the Amazon, which had been practically deactivated since the beginning of the 20th century, returned at the hands of the 'rubber soldiers'. These were mostly Northeastern migrants who heeded the state's call for the production of rubber in the forests of the states of Acre and Amazonas as part of the Brazilian war effort. See Silva (1982). 
of the country, nor the vested agrarian interests still strongly represented in the state apparatus. Thus, Vargas's speech is a resigned recognition of the fragility of state power vis-à-vis the still predominant agrarian power ${ }^{10}$.

In fact, his impotence in relation to the inexorable and uncontrollable population dynamics had for some time been a worry for Vargas. In a speech in the state of Bahia on August 11 th, 1933, when analysing the consequences of the end of slavery for those directly affected, Vargas said that in the caatinga (semi-arid Northeast) region poor rural people were subject to the climate and the shortage of resources.

They languish in an uprooted way, sometimes nomadically, living day by day, subjugated to the rapaciousness of the new masters who exploit their crude work as if they were backward serfs. This disorganization has been exacerbated by the exodus of people from the countryside, attracted by the illusory ease in finding plentiful and well-paid jobs, to the intense life of the urban centres. The urban proletariat has increased disproportionately, leading to pauperism and all the ills resulting from the surplus of activities without permanent occupations (1938, vol. 2:115).

\footnotetext{
${ }^{10}$ In 1939, two years before this speech, coffee and cotton were $60 \%$ of the overall value of the country's exports (IBGE, 1941:90). Besides showing the fragility of its foreign trade, this number reveals the enormous dependence of the nation in relation to a handful of large producers of coffee and cotton, as well as Vargas' difficulty in directly confronting their interests. It is important to remember that, in his acceptance speech for the provisional government, on November $3^{\text {rd }}$, 1930, Vargas listed among the tasks of the revolutionary government 'non-violent backing for the progressive extinction of the latifundio and, this way, protecting the organization of the small holding' and stimulating the worker to 'build with his own hands, on his own land, the foundation of his prosperity' (1938, vol. 1:73). In 1941, this task was still only a promise, and would remain that way for the following decades.
} 
It was this pauperism and its ills (the risk of the poor succumbing to communist proselytizing obviously being one of them) that Vargas feared in 1941, hence the need to fix the rural population in the countryside.

In addition, Vargas was not ignorant of the material difficulties of the state he inherited from the First Republic, despite the recurring apologetic for his own work of statebuilding. Thus, reviewing his ten years in power in a speech at Rio de Janeiro's Santos Dumont Airport during a banquet offered to the dictator 'by the conservative and working classes' on November 11th, 1941, he rejoiced in the fact that he had collected twice as much in taxes in 1939 as in 1930, and had spent almost twice as much as ten years before (1941: 170). He was telling the truth, since tax collection had in fact almost doubled in Brazilian currency; but he was not telling the whole truth if one allowed for inflation and considered the number of people he wished to promote through his social policies. In this new context, federal per capita tax collection had been 0.90 British pounds in 1930, and 1.18 in 1939. This was a rise of almost 30\% in relation to 1930 , but far off the $100 \%$ claimed $^{11}$. Although tax collection had increased in ten years, so had the population, and at high growth rates. That ended up nullifying some of the effects of the increased state capacity in tax collection visà-vis the needs of the population. If it is true that, in mil réis, the expenditure in 1939 was almost twice as much as in 1930 (4.3 million contos de réis, as opposed to 2.5 million), in British pounds the amount was 61 million, instead of 51 million ten years before. That is, the increase was close to $20 \%$ in real terms. But since the population had also grown $20 \%$ in the period, per

11 This is calculated by the IBGE (1941:120), with data for the revenue per capita, deflated by the value of the British pound in mil réis (presented in the same publication, p. 64, table 2). 
capita expenditure was exactly the same in 1930 and in 1939: $£ 1.35$ per person.

Whichever way one looks at it, by putting social issues at the forefront of his political project even in the face of multifarious structural impositions, Vargas and his allies, especially the tenentes to whom this issue had been dear since their first movements ${ }^{12}$, did not invent state regulation centred on social rights detached from reality, as proposed for example by John French in works published in 2001 and 2004. Even if the urban world had no more than $30 \%$ of the Brazilian population, and if only a tiny percentage of those were employed in manufacturing - the main priority of V arguista regulation -, it did not anticipate facts. In fact, it was perfectly in tune with the apparent threat of pauperism that the rural exodus was provoking in the big cities. Thus, in 1940 the proportion of manufacturing workers in relation to the economically active population surpassed $26 \%$ in the Federal District (that is, the city of Rio de Janeiro) and 38\% in São Paulo ${ }^{13}$; and, considering only men, it is probable that the number would reach $30 \%$ in the Federal District and more than 40\% in São Paulo ${ }^{14}$. Excluding domestic servants, 75.6\% of those with jobs were wage earners in the Federal District. Modern social questions, the midwives of social revolutions and reform movements that led to European social legislation, were visible in Rio de Janeiro, capital of the country, and in São Paulo, already an important industrial centre. It was these questions that Vargas thought he was responding to when he proposed his legal structure of social protection. However, since the transforming

\footnotetext{
${ }^{12}$ As described in Tavares de Almeida (1978) and Gomes (1979).

13 There were 273,000 workers in São Paulo, according to Dean (1971:127), in an economically active population estimated at $55 \%$ of the 1.3 million inhabitants.

${ }^{14}$ The numbers are an approximation because the data published in the censuses included the unemployed and those in poorly defined activities in the same category. See IBGE (2003) for data on the population.
} 
state remained feeble in its capacity to implement its policies, it was one thing to institute legal norms and another to make them effective. This task fell, to a large extent, to workers themselves, not only individually through labour courts or in small-scale resistance in the day-to-day life of companies, but also through their representative institutions, that is, the trade unions shaped by Vargas himself ${ }^{15}$.

\section{'Regulated citizenship' and beyond}

Vargas's legislation will not be analysed here. Literature on that is already very considerable and, even though there is much controversy over its significance, that is not so much in terms of its content ${ }^{16}$. I would only point out the plausibility of a particular interpretation of this legislation in the area of social protection. I start from the premise that the reader knows a little about its general outline, which included establishing a minimum wage, working hours, paid weekly rest, vacations, protection of women's and children's working rights, retirement, etc. This framework is important to what I am proposing here, not so much for its real or supposed effectiveness but for the meaning it acquired in the broader social dynamic. From my perspective, this is something that has still not been considered

${ }^{15}$ It is widely known that a significant amount of Vargas' legislation had been demanded by the workers movement before 1930, as Moraes Filho (1979[1952]) first proved, demolishing the myth that Vargas gifted or granted workers their rights. This led Gomes (1988) to suggest that Vargas took the workers' discourse and transformed it into a control mechanism over the workers themselves. Later on we will see that, although relevant in itself, the discussion about the myth of the gift is disconnected to the central argument of this chapter.

16 Some obligatory references are Simão (1966), Dean (1971), Werneck Vianna (1999), Tavares de Almeida (1978), Santos (1979), Erickson (1979), Gomes (1979 and 1988), French (2004), and Fischer (2008). Differences of opinion in regard to content usually refer to the regulations which this or that author includes (or leaves out) in the legal framework of Varguista social protection. 
by the literature on the issue. My starting point is the concept of 'regulated citizenship'. The intention is to show that it was a promise of social inclusion of the masses formerly disregarded in the process of development of the nation. It was a promise with a huge impact on the projects, hopes, expectations and customs of the working people. It had long-lasting consequences for capitalist sociability in general and for the reproduction of inequalities over time.

The concept of 'regulated citizenship' is an irremovable concept of the analytical arsenal available on the Vargas era. It encapsulates an enormous number of meanings in what is, at the same time, a strong and simple idea. Wanderley Guilherme dos Santos' formulation is well known, but it is worth reproducing in its entirety, to better understand what I am proposing:

By regulated citizenship I mean the concept of citizenship rooted in a system of occupational stratification, not in a code of political values. Furthermore, this system of occupational stratification is defined by law. Put differently, citizens are those community members who are in any of the occupations recognized and defined by law. The expansion of citizenship occurs, first of all, through the regulation of new professions and/or occupations, and also through the enlargement of the spectrum of rights associated with these professions, rather than the expansion of values integral to the concept of membership of the community. Citizenship is inserted in the profession and the rights of citizens are restricted to the legally recognized rights they occupy in the productive process. All of those whose occupations are not recognized by law consequently become pre-citizens [...]. The carteira de trabalho [occupational history record] is the legal instrument that proves that there is a contract between the state and the regulated citizenship. As a matter of fact, it becomes more than evidence of having a job, it is a civic birth certificate (Santos, 1979: 75-76). 
Or, to put it simply, 'whoever has a job gets benefits', as Angela de Castro Gomes articulated (1988: 189ff). What I propose is the following: if in the definition of 'regulated citizenship' we take into account not only those rights associated with the status of worker in the formal sector of the economy (that is, the professions recognized by law), but also the full Varguista project of integral elevation of 'the Brazilian man' (as it was actually experienced by the recipients of this project), citizenship ceases being seen as a set of rights that forever separate those included and those excluded from the system being established. Instead, it begins to indicate a porous and fluid system whose entry door opened and closed many times throughout the paths of those who applied for it. Inclusion in the world of rights could be short-lived, and so could exclusion. This occurred in such a way that real inclusion, brief or permanent exclusion and renewed expectations of new inclusion were part of the same general process of 'regulated citizenship', or of its effectiveness.

In an initial approach to the problem, it seems uncontroversial to me that the notion that those that do not have a profession are pre-citizens, as seen in Wanderley Guilherme dos Santos' original formulation, means simultaneously exclusion from the world of rights and the existence of mechanisms through which pre-citizens may be included at some point, thus becoming full members of the community of rights. Thus, exclusion may be temporary, that is, citizenship becomes a possibility for these pre-citizens. This idea is inscribed in the concept of 'regulated citizenship': for Santos, Vargas defined full citizens as well as a set of mechanisms that perhaps made this environment a believable possibility for pre-citizens ${ }^{17}$, or

\footnotetext{
17 The concept differs from the notion of sub-citizenship, which covers what Souza (2000) calls the ralé (riff-raff), who are permanently excluded by the Brazilian process of 'selective modernization'. The argument here is the complete opposite of this simplification.
} 
those in the process of becoming citizens. I will argue here that, more than a possibility, 'regulated citizenship' was a promise, and that this notion accurately captures a substantial part of the Brazilian social dynamic after 1930, possibly even more so than was envisaged by Wanderley Guilherme dos Santos.

For the typical Brazilian worker, specifically the one emigrating from the countryside, villages and small towns, fleeing poverty or in search of a better life, access to full workers' rights was a long and sometimes frustrating path filled with obstacles ${ }^{17}$. To begin with, Brazilians almost never had legal identification. This was partly because of the circumstances of life for a significant part of the rural population, almost always far from the urban centres where registration was carried out. But it had partly to do with pure and simple resistance. This came from the hardly unrealistic idea that the state was an enemy of the people, trying to control them, enrol them in the army, enslave them, vaccinate them, sanitize them, or simply persecute them in an arbitrary manner ${ }^{18}$. Nevertheless, to obtain a carteira de trabalho or any other document, as well as enrolling children in public schools (for decades these would continue to be incapable of offering enough places) or obtaining access to health care, registration was obligatory. Hence, obtaining a birth certificate was the first step in an always strenuous path to acquiring legal rights. Even in 1948, long after the process of consolidation of 'regulated citizenship', $23.4 \%$ of shanty dwellers in Rio de

18 The populations of the 19th and early 20th centuries had enough reasons to mistrust the state's attempts to interfere in their daily lives. Riots such as the Cumbuca (against the compulsory military lottery) in 1874, or against the vaccine in Rio de Janeiro in 1904, mainly stemmed from the perception that the state was going too far in its attempt to regulate poor people's lives. This also explains the resistance to the census and taxation in rural communities and sanitation policies in the cities. For census and taxes, see Queiroz (1965:216). I analyze sanitary measures in Cardoso (2010). 
Janeiro did not have this document (Fischer, 2008: 124) ${ }^{19}$. There is no reason to suppose that the situation would be better in the remaining urban centres of the country.

Having acquired legal identification, a carteira de trabalho (the 'civic birth certificate', as W. G. dos Santos puts it) required additional effort. As Fischer (2008) demonstrated, workers needed to give a complete set of data to the National Department of Labour, including marital status, education, occupation, address, name of parents, as well as a photograph. Fingerprints were registered there, and the applicant needed to inform his current and former employer's names, activities, and locations, besides the wages earned and the date of their first and last days in the job. Names, activities, and dates of birth of all dependents were also required, as well as any unions of which the worker was a member. Thus far, this was theoretically simple information to provide, were it not for the fact that everything had to be proved by documents or by two witnesses who had a carteira de trabalbo. Workers with precarious job statuses, an erratic work history (that could not be confirmed by documentation) or irregular domestic arrangements (for example, a man with a common-law partner or a single mother) knew beforehand that the document would be hard to obtain and in any case would be unlikely to benefit them by being a passport to a formal job because it would record past irregularities. But there was more. If male, the candidate needed to prove that he was up-to-date with his military service. Illiterate candidates needed three witnesses, one of whom had to be willing to sign the paperwork that constituted the application form. Certificates or letters from employers proving their professional skills or, once again, two witnesses

\footnotetext{
${ }^{19}$ In Rios and Mattos (2005) we find many testimonies of descendants of slaves who had no formal birth certificate. This lack was common in quilombola communities (Gomes, 2006) and in communities of Northeastern migrants in cities in the Southeast (Perlman, 1977; Durham, 1973).
} 
with a carteira de trabalho, were required from all candidates. Finally, the carteira cost five cruzeiros, an excessive amount for the unemployed and for workers who earned a minimum wage or less (ibidem: 127ff). To many, these requirements were real obstacles to entering the world of rights, something which was routinely lamented by government social service professionals, for whom the rules for acquiring the carteira were 'very onerous' on the poorest $\mathrm{t}^{20}$.

This brief overview dictates at least two important specifications to the concept of 'regulated citizenship'. First of all, as previously suggested, the process of establishing social legislation generated a lengthy series of gradual iterations that made comprehensive social inclusion a more or less distant promise, according to the worker's position in the structure of distribution of money, goods, services, rewards (and obviously) rights and not a clear division between the included and the excluded. This means that rights might have been perceived as a 'privilege' for those who were able to cross the turbulent sea of bureaucracy involved in the acquisition of the documents that allowed for a formal job, not to mention the job itself. Besides, since there were ways of earning this 'privilege', inability to acquire legal identification or, later on, a carteira de trabalho, was seen as a personal failure, especially because others (neighbours, relatives or friends of the loser) were able to. All that was needed was for the worker to formally adhere to impeccable norms in the state's eyes, such as having a birth certificate, being in a good marriage and proving one's professional skills. It was not the state who seemed to impose bureaucratic obstacles to poor and illiterate workers. It seemed that workers were not up to the norms of the state as creator of a new citizenship where none had existed, according to its own ideology.

${ }^{20}$ An SOS Bulletin mentioned by Fischer (2008:129). 
Fischer, from whose work I extrapolate to defend the idea of a continuum of accession to rights, did not consider this last aspect. The dream worker of Oliveira Vianna, Getúlio Vargas and Marcondes Filho ${ }^{21}$ was an educated, healthy, clean breadwinner. He had a profession and was granted social rights because his profession was regulated by the state ${ }^{22}$. The three ideologues knew this man did not exist, which is why the Revolution's task was to create him. 'Regulated citizenship' was a project for the whole nation. However, it should be expanded in accordance with each person's ability to improve or become the model person that the state wished to promote. That is why, from its own point of view, the state was not creating a privileged sector. It was pointing out to Brazilians that socioeconomic security was accessible to anyone, as long as he or she was up to the task being asked of them and which, in any case, "was for their own good'. And, obviously, as long as there were regulated jobs for all. But jobs were just one of many aspects of the Varguista project of inclusion of citizens.

The second consequence of this arrangement for the concept of 'regulated citizenship' is that this was, in a very specific sense of the word, a process. Not only did the legal order appear to be possible to Brazilians, it also legitimated the struggle for its effectiveness. Before 1930, the struggle for social and labour rights was hampered by the liberal Constitution of 1891. Any measure limiting the freedom of contract between free and equal people was seen as unconstitutional, and the demand for worker protection was simply considered subversive. Therefore, the social question itself was unconstitutional. Under Vargas, on

\footnotetext{
${ }^{21}$ Alexandre Marcondes Filho, Minister of Labour in the last years of the Estado Novo, was one of the main people responsible for the consolidation of the myth of Vargas gifting rights, with his ten-minute weekly radio chat on Hora do Brasil. The more than 200 lectures given between 1942 and 1945 were analyzed by Gomes (1988:229-256).

22 See also Weinstein (1996) and Dávilla (2003).
} 
the other hand, full rights were there for those who were willing to conform to the requirements defined by the state. According to Oliveira Vianna, unlike the classical model of state development, a worker did not need to struggle for his rights. Finding the means to be entitled to benefits, means granted by the state itself, was enough for him. And, importantly, if even then the employer refused to follow the law, the worker could resort to the state to secure its enforcement. This could be done, for example, through an appeal to the Labour Tribunals or to one's trade union, which was also guaranteed by the state.

This means that, notwithstanding the apologetic discourse of justification of the Varguista regime, social and labour legislation ended up establishing a legitimate field of dispute for its own embodiment in the environment in which it occurred, whose source of legitimation was the state itself. In addition to this, the horizon for the struggle for legal rights legitimately became the horizon for class struggle in the country. Therefore, 'regulated citizenship' became the institutional form of the class struggle in Brazil: a struggle for enforcement of existing legal rights; a struggle for expansion of legal rights to new professional categories; and a struggle for new legal rights. Furthermore, this means that if social and labour rights (and education and health services) needed to be embodied through regulated class struggle, then 'regulated citizenship' needed to be achieved by its candidates, both individually and collectively. Whether or not it was granted by Vargas (a debate that has consumed so much energy on the part of scholars in Brazil) ${ }^{23}$, the fact is that in the process of making

\footnotetext{
${ }^{23}$ As mentioned before, the myth of the granting (or gifting) of workers' rights was deconstructed for the first time by Moraes Filho (1979[1952]). Martins Rodrigues (1974) is an advocate of the school of thought which holds that the workers, in their political and labour struggles, would never conquer what Vargas established through law, especially considering its ordering and extent. Weffort (1978) is among the many who do not agree with this. Gomes (1988), in accordance with Moraes Filho, suggests that the workers' discourse was seized
} 
itself real, social legislation was appropriated by the workers, and 'regulated citizenship' was the form of this appropriation in its smallscale and everyday process.

This reveals the more profound meaning of the category of pre-citizen, a necessary complement to the concept proposed by Santos: in the process of establishing social legislation, all workers were, from the beginning, pre-citizens; when they effectively and gradually were granted legal rights by the state, they partly left their status as pre-citizens, since they needed to struggle to see their rights acquire effectiveness in their personal and collective lives. Finally, this struggle was not equally accessible to all. So much so that these legal rights were not made universal, nor given the embodiment its ideologues and later on the workers themselves (organized or not) intended it to have.

\section{The promise and the real Brazil}

The limits to the universalization of 'regulated citizenship', so as to include all those defined by it as pre-citizens, were significant and were far beyond the intervening capacity of the workers themselves. Before showing why, it is necessary to recognize that it seems paradoxical that 'regulated citizenship', understood as restricted to a certain part of the population, could be made universal. But it is of the essence of social and labour rights to delimit those who receive entitlements under their regulations ${ }^{24}$. For example, unemployment benefits make no sense to the owners of the means of production, children, or

upon by Vargas, who emerged as the generous father of the historical demands of the labour movement. More recently, Ferreira (1997) and his colleagues have tried to recover the idea that Vargas actually introduced something new in the concession of social rights. French (2004) tries to put an end to the controversy. Although I find it relevant, this debate is disconnected from the central argument of this chapter.

${ }^{24}$ See Supiot (1994) on this. 
the retired. The same goes for paid weekly rest. Everywhere in the world, retirement only belatedly included those that were not wage earners ${ }^{25}$. For the concept of 'regulated citizenship' to make sense, the relevant problem is not to recognize that social rights are never universal in the sense of defining those entitled as co-extensive with the whole population, but to know if they are universally available or universally effective for the people they entitle. This is the meaning of pre-citizen in Varguista citizenship: his status as a worker made him an instant potential holder of legal rights, but to obtain this he needed to meet requirements and get a regulated job, as we have said before. The pre-citizen is essential to the concept of 'regulated citizenship', because if all potential holders of social rights met the requirements, that is, if they all stopped being pre-citizens, then citizenship would no longer be regulated. It would simply be social citizenship, and indistinguishable from Marshall's classic concept. Brazilian citizenship was regulated because for the most part it remained a possibility. More appropriately, I argue that it remained as a promise of inclusion that became worth fighting for.

Having said that, the Brazilian social dynamic after 1930 led to Vargas's worst fears in relation to the risk of rural exodus in his project of moral, economic, and social elevation of the Brazilian man. Most people led extremely vulnerable lives, no matter whether they lived in the agrarian world, in rural neighbourhoods, or in villages and small towns, in the periphery of big cities or in their central areas; and they were thus prone to seek minimum conditions of survival somewhere else every time their current life became unbearable. The bibliography on migration in Brazil invariably indicates that natural catastrophes, short-lived or structural hunger, or even the routine or violent disintegration of traditional ways of life did not represent special

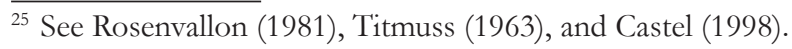


reasons for the migration of the rural population ${ }^{26}$. At best, they hastened or anticipated movements that would occur anyway. Geographical mobility was always a distinguishing mark of this vulnerable population ${ }^{27}$, who sought their means of survival in a social climate characterized by huge restrictions on their actual aspirations, projects, and possibilities, notwithstanding important regional differences.

At some point in the 5th Brazilian century, the urban world began to exert an irresistible gravitational force over this population, leading to an overwhelming movement of people and families to the cities in a very short period of time. This has also been studied before, but it is necessary to give an idea of the numbers involved for the correct comprehension of the issue at hand. In the 1950 s, the equivalent to $24 \%$ of the rural population at the beginning of the decade left the countryside. That is, one in every four country dwellers sought out the cities during the decade. In the 1960 s, the figure was $36 \%$ of those living in the countryside at the beginning of the decade (more than one in three) and during the following decade nothing less than $42 \%$ (or more than two in five) of the rural population of 1970 (Merrick,

${ }^{26}$ See, albeit from very different perspectives but with the same results, Durham (1973), Perlman (1977), Sales (1977), Coutinho (1980), Alvim (1997), Linhares and Teixeira (1998), and Fontes (2008). There is a short review in Hasenbalg (1991). For the inheritance mechanisms as a regular source of expelling sons of small landowners, see Willems (1961) and Moura (1978).

27 'In a culture which is living on the edge, any variation in work conditions represented by climatic or soil differences, or even in variations of benevolence or severity on the part of the employer, frequently represents the main difference between survival and hunger. It is this factor that makes mobility such a generalized feature of Brazilian rural life' (Durham, 1973:120). In the $16^{\text {th }}$ and $17^{\text {th }}$ centuries, nomadic rural populations were strongly contested in Europe, as shown in Castel (1998). And the destruction of the knots that tied these workers to the land in the 18th century and their mass migration to the cities is at the source of Western capitalism, as Marx shows in the memorable analysis of what he called 'primitive accumulation'. Also see Thompson (1987). 
1986: 62$)^{28}$. It is impossible to argue counterfactually that those leaving the rural areas or villages of Brazil would not have sought the cities if the labour market had not been so ordered and regulated in them, making them attractive and fuelling the collective utopia of social and labour rights. The difficulty with arguments of this nature is that the millions of poor and destitute who inhabited the countryside throughout the centuries did so merely because that was the horizon of their lives. That is, there was no alternative for them except to choose between one farm boss and another. And if not, then the choice was a precarious and miserable situation in some other part of Brazil's immense territory. It is reasonable to suppose that people in this situation would have preferred to migrate to the cities as soon as they envisaged a way out from their destitution, in the same way that hundreds of thousands left the Northeast for the Amazon in the two big rubber cycles, and in the same way that they returned to their region, also in their hundreds of thousands, following the end of these cycles or as a reaction to improving conditions in their home regions ${ }^{29}$. The attraction of the city would not be different from the attraction of the Amazonian El Dorado. The city would be a place of 'illusory opportunities', as Vargas argued.

But there is strong evidence in favour of the attractiveness of social rights. We begin with the lament of an employee of the Department of Immigration, who studied cases of immigrants who passed through the Workers Orientation Service in Rio de

${ }^{28}$ Between 1920 and 1960 , Minas Gerais was the state with the most net internal emigration (1.8 million people left the state in forty years), followed by Bahia with almost 900,000 and Alagoas with around 450,000. See Villela and Suzigan (2001[1973]:284). This number corresponds to the number of foreign immigrants entering Brazil between 1871 and 1920. See Maram (1977:178). Overall, 5.5 million people migrated from their home states to other regions in these forty years, with São Paulo receiving 1.5 million migrants, Rio 1 million and Paraná almost 1.4 million (Villela and Suzigan, ibid.).

${ }^{29}$ For the mass migrations in Brazil during the rubber cycles, see Silva (1982), Costa Sobrinho (1992), and Martinello (2004). 
Janeiro in 1949. The irresistible force of the city is explained by him in the following terms: 'In the Northeast, J. B. S., working as a day labourer in agricultural activity, earns ten cruzeiros per day, all day in the sun and in the field. He receives a letter from his single godfather in Rio, revealing the following: a bricklayer's assistant [...] earns 43 cruzeiros, working from seven to four, with one hour for lunch' (Apud Fontes, 2008:51).

The relative's letter was not trying to seduce J. S. B. only through higher wages. He also mentioned working hours and rest, central aspects of labour market regulation. All the information added up seemed to the ministerial bureaucrat to be what I am calling 'the attractiveness of legal rights'.

The promises of social rights (especially the minimum wage), as well as access to public services such as education and health (always appreciated by the poor), seem to have attracted not only the wandering populations from the countryside but also many of those who had once been subjected to the traditional patterns of domination (which were, at the same time, actual, albeit subordinate means of socioeconomic security) and who in other circumstances might have remained where they were. In this interpretation, urban workers' rights established a parameter against which rural workers began to judge their current situation. This led to profound changes in relation to how far they would accept their traditional destitution and subordination $^{30}$.

In a study with shanty dwellers in Campos do Jordão in 1973, Schühly (1981: 97) noticed, likewise, that only $18 \%$ of 190 interviewees had an identity card. However, of the sample of 195 workers, $82 \%$ had a carteira de trabalho, although only $61 \%$ had

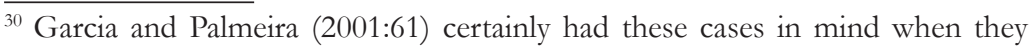
wrote that 'the big industrial cities began to [...] mean the place where there were legal rights, to which the rural world could only be portrayed as 'a place of hardships' and a world of arbitrariness, subjection, and imprisonment. 
a formal job. Poor shanty dwellers preferred a carteira de trabalho to an identity card, even though having it did not guarantee them access to the formal labour market. At best it was only the symbol of a promise. In the same way, of the 134 migrants who answered the question about reasons for migrating, 42\% mentioned the search for 'better jobs' and 48\% had left their home town or village because of a 'lack of jobs'. How much of the promise of legal rights is implicit in the search for 'better jobs' is hard to gauge. But it seems plausible to assume that this reason was present for a considerable number of workers who, when searching for better jobs, brought with them their carteira de trabalho ${ }^{31}$.

Sparse but just as robust evidence such as this fills the abundant literature on rural-urban migration in Brazil and on the consolidation of the urban world. But it is frequently invisible to the researchers themselves. So let us return to the work of Lopes (1967: 34). While analysing the motives for migration of factory workers in two small towns in Minas Gerais, the author points out that 'the urban setting of these communities, their biggest resources, whether educational, medical-sanitary or even work security, exert perceptible attraction over rural workers and small farmers whose means of subsistence in the countryside are in crisis' (my emphasis)

Later in the same paragraph, Lopes states that 'a [worker] claims that he came with his family 'to pay institute and educate his children", while others mention additional 'reasons of this sort'. To 'pay institute' and other 'reasons of this sort', in the case of factory workers in 1957 when Lopes was doing his field research, meant the worker joining one of the official social security institutes. The attractiveness of 'regulated citizenship' goes virtually unnoticed by the author's always sharp analysis.

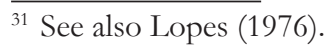


In the same speech it is backed up by the second most important promise of Brazilian development, related to the education of children as a path to social mobility. Later, Lopes also maintains that workers value factory work over other urban occupations, 'not only because of the wages, but also because it offers more security (medical assistance, retirement, etc.)' (ditto: 51). Once again the 'etc.' reveals the minimal importance attributed in the analysis to the integrative promise of labour rights, such as a wage (at the time it was generally a minimum wage), which seems to have been a central reason for those who sought out the cities throughout these decades.

These indications of Brazilians' adherence to the integrative promise of social rights suggest that, if on the one hand the process of their inclusion in the world of these rights was unequal and intermittent, on the other hand belief in the possibility of inclusion in 'regulated citizenship' seems to have been universal. In 1976, workers with rights (those with formal jobs or government employees) were $59 \%$ of the urban workforce in the country. However, indications are that most workers, whether currently employed or not, had achieved entitlement to a formal job if any such job showed up.

That is what Graph A suggests. It presents the growth curves of the urban economically active population - EAP (or workers of ten or more years that were in a job or looking for one), the number of carteiras de trabalbo issued, and the number of contributors to social security between 1940 and 1976. Contribution to social security, in the absence of more accurate indicators, is considered here an approximate measure of the proportion of workers participating in the regulated sector of the economy. In fact, it is quite accurate, since until at least 1971 the possibility of retirement was restricted to workers 
with carteiras and government employees ${ }^{32}$. The numbers in the graph show the addition of new members of the EAP, those with carteiras and those with social security in each period. The numbers are significant. In 1940, the urban EAP was made up of a little more than 5 million people. Until then, the Ministry of Labour had issued less than 1 million carteiras, and contributors to social security were slightly less than 2 million people, or around $38 \%$ of those in employment. Hence, work that was regulated and protected by social and labour legislation did not reach $40 \%$ of those in employment in the cities $^{33}$. Between 1940 and 1950, the urban EAP gained another 1.8 million people, while new social security contributors were less than 1.2 million. Nevertheless, the Ministry of Labour issued 2.7 million carteiras during the same period. Thus, $150 \%$ more carteiras were issued than the growth of the EAP, and $230 \%$ more than the beneficiaries of social security. This seems to be a strong indication that the workers believed in the possibility of their inclusion into the consolidating formal market, since they qualified for this (that is, they got their carteiras) in a superior proportion to the jobs created (as measured here by the urban EAP). Moreover, the number of holders of carteiras was far superior to the regulatory capacity of the social security system, i.e., the capacity to include new city dwellers in the world of social and labour rights in an environment of enormous bureaucratic restrictions to entitlement. It seems that the belief in the promise of legal rights must be among the explanations for the always higher number of qualifications

32 Prorural was created this year. It was a retirement program for rural workers. In 1972, domestic servants were included in the system; and in 1973 selfemployed workers. See Santos (1979:35-36).

33 This represented a mere $12 \%$ of the total employed population, since $70 \%$ of them were in the countryside. 
than availability of these legal rights, on the part of workers who migrated from the countryside to the cities.

This dynamic would accelerate in the following decades. Between 1950 and 1960, carteiras issued were 36\% higher than urban EAP growth, and no less than 377\% more than the growth in the number of social security contributors. Between 1960 and 1970, carteiras issued surpassed EAP growth by $213 \%$, and by $271 \%$ in the six following years (until 1976). There were 2.78 times more Brazilians becoming holders of a carteira than those effectively part of the social security system in the period analysed here (1940-1976), and 1.92 times more than those part of the $\mathrm{EAP}^{34}$. This means that the increase in social security contributors corresponded to only $38 \%$ of the increase in holders of carteiras in this period. In this context, the first number (2.78 times) must be taken as the measure of inflationary belief of Brazilian workers in the promise of legal rights, which led to an expectation of inclusion almost three times greater than the real possibilities in the formal urban labour market for over three decades. Seen from a different angle, one can say that the objective discount rate for expectations of social protection was $62 \%$, which was the proportion of carteira-holders that exceeded the number of social security contributors throughout the years.

\footnotetext{
${ }^{34}$ An important part of the explanation for entitlements being so much higher than the EAP has to do with the qualification of women for formal jobs, even if not necessarily exercised throughout their lives.
} 
Graph A. Evolution of urban EAP, number of work books (carteiras de trabalho) issued by the Ministry of Labour and number of contributors to social security: Brazil, 1940-1976

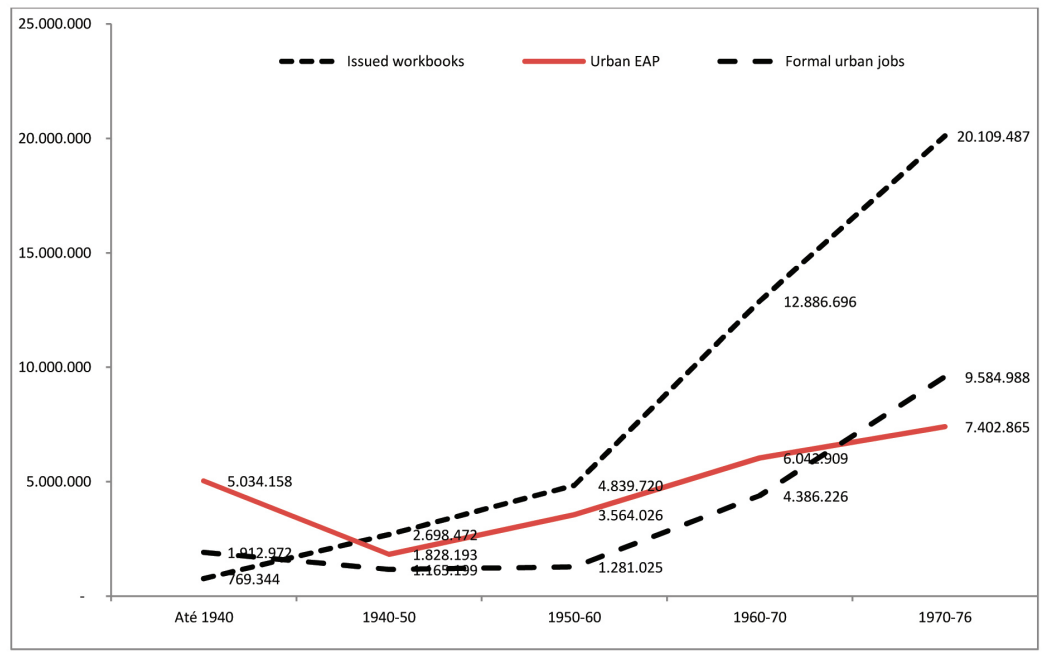

Sources: Anuário Estatístico do Brasil (IBGE, many years); and IPEADATA for urban EAP estimates and contributors to social security. Data was compared with those from IBGE (2003) and may present small differences that do not influence the general trend.

This confirmed Vargas's worst fears in relation to the risks that rural-urban migration represented to his civilizational project.

It should be noted that, although the promises of protection suffered a substantial discount rate, it seems undeniable that registered jobs in Brazil represented, to growing segments of urban workers (and, it seems, to segments of rural workers $\operatorname{too}^{35}$ ), a normative reference point for the shaping of individual and collective expectations in terms of what could

35 Rios and Mattos (2005:55-57 and 248) suggest that Vargas, especially after 1937, had generated expectations of contractual rights also among rural workers when he opposed coronelismo in the countryside. Not by chance, the 
be called 'minimum requirements of civilization', below which the labour market could not operate in a legitimate manner. The minimum wage, the right to regular vacations, paid weekly rest, a Christmas bonus (equal or close to one's wages) etc., became parameters that also began to function in sectors of the informal wage-earning market, in the sphere of tacit agreements between informal employers and wage earners without carteiras who thought these rights were fair. Although it never became universal, the formal market structured a set of social and economic relations that occurred outside it. The reason was that urban wage earners expected sooner or later to become a part of it. This expectation was in fact achieved now and again during the working lives of men and women, because of the always high rates of turnover in the Brazilian urban economy, especially in the less skilled occupations ${ }^{36}$.

In regard to this, some occupational trajectories of the migrants studied by Lopes in another ground-breaking study are extraordinary (1971: 41). One person was a factory worker for a year and a half, returned to his smallholding for 21 days, became a store salesman for a year, and once again worked in a factory for four years. Another washed buses for three months, was a factory worker for eight years, worked on a farm for two more, then again in a factory for two months, and once again in a factory for two years. A third man was a bricklayer's assistant for two months, a baker's apprentice for two weeks, a factory worker for a year and a half, a salesman earning by commission for a non-specified time, a factory worker for 15 days, and once again a factory worker for two and a half years. These erratic trajectories are perfect examples of the socioeconomic

periodization of citizenship has two founding moments in the memory of slave descendents: the abolition of slavery and Varguista labour legislation.

36 Turnover in Brazil is studied at length in Cardoso (1999a and 2000). See also Barros and Mendonça (1996). 
insecurity of urban workers with low qualifications. They were subjected to market dynamics entirely beyond their control, since the lack of any specialization reduced their bargaining power in an extremely saturated market ${ }^{37}$. The important thing here is that the regular passage, although short-lived, through a formal and protected job ended up leading to expectations of equal retribution in the informal wage-earning market, and this at times occurred ${ }^{38}$. And it seems that workers believed that the formal labour market would welcome them again at some point in their working lives ${ }^{39}$.

\section{The promise and inequality}

Even though workers adhered to the Varguista utopia and struggled to embody 'regulated citizenship', the rewards associated with it were almost always insufficient to secure the 'integral elevation of the Brazilian man'. As an example, take the setting of the minimum wage, advertised by the Estado Novo as one of the main instruments of elevation. The wage was defined by presidential decree no. 399, of 1938, as 'the minimum amount owed to any adult worker, independently of gender, for a normal days' work and capable of fulfilling, within a certain period and region of the country, his normal needs of food, housing, clothing, hygiene, and transport'. This text would later be incorporated in the Consolidated Labour Legislation (CLT)

\footnotetext{
37 The erratic character of the non-specialized workers' trajectory, the majority of the migrant workforce, did not cease with time. Cardoso (2000), Guimarães (2004), Cardoso et alii. (2006), and Guimarães (2009) portray the job instability that characterizes the labour market to this day. See also Chapter 5 in this volume.

38 The literature on the influence of the minimum wage and other labour rights is abundant in Brazil. For a good review, see Ulyssea (2005). Lopes (1976) and Sigaud (1979) are classic studies on the importance of legal rights in the shaping of the social identities of sugar cane and sugar mill workers in Pernambuco.

${ }^{39}$ Once again see Fontes (2008).
} 
and improved on by the 1946 Constitution, which would include the needs of the worker and his family.

The presidential decree no. 2162, which defined the first minimum wage in May of 1940 based on specific regional studies throughout 1938 and 1939, established it at 240 mil réis for the Federal District (city of Rio de Janeiro). This was the largest amount in the country. São Paulo was granted 220,6 mil réis, while in certain regions of the interior of the North and Northeast the amount did not surpass 90 mil réis ${ }^{40}$. This last number was equivalent in 1939 to less than $70 \%$ of the monthly expenditure on food for one member of a middle-class family in Rio de Janeiro ${ }^{41}$. This means that the minimum wage of 240 mil réis was enough to provide food to 2.6 members of the same family per month and nothing more ${ }^{42}$. Rental for housing for this family would require 2.6 minimum wages. It is true that the minimum wage was not meant for middle-class families, who spent an average of 200 mil réis in 1939 just on domestic servants. But this shows the purchasing power of the income decreed by Vargas and divulged with great fanfare in the Labour Day celebrations of 1938. It also shows the tolerance of social inequality inherent in the minimum wage legislation: that a middle-class family from Rio de Janeiro spent, in 1939, on average no less than 10 times the minimum decreed in $1940^{43}$.

\footnotetext{
${ }^{40}$ See Montali's (s. d.) work, available at http:/ / www.dieese.org.br/cedoc/007171. pdf; and Lowenstein (1942). Montali maintains that deciding the minimum did not take into account families' real expenditures, which was anticipated by the 1938 law, but only the average of incomes lower than 420 mil réis.

${ }^{41}$ Data from IBGE (1941:94).

${ }^{42}$ Inflation measured by IPC-Fipe between January and June of 1940 for the city of São Paulo was of $7.2 \%$ according to the data-series available at http:/ /www. ipeadata.gov.br. Since the minimum wage came into effect in July 1940, the cost of living for this same family had changed in relation to 1939, but not to the point of qualitatively changing the amount.

${ }^{43}$ Data from IBGE (1941:94). The total average expenditure of a family such as this in the federal capital was 2,4 contos de réis in 1939.
} 
If we consider that middle-class women rarely worked and, therefore, the man of the house had almost certainly been responsible for generating the income required for this expenditure, it can be surmised that the monthly income of a middle-class professional was far more than 10 times the minimum wage in 1940 (considering current expenditure and some savings).

The nominal value of the minimum wage was set at a low level and, furthermore, remained frozen between July 1940 and May 1943, which represented a real loss of purchasing power close to $40 \%$, which was the accumulated inflation during that period. The 25\% increase given by Vargas in May of 1943 did not replace the losses, which were compensated with another rise of $27 \%$ in December of the same year, following $12 \%$ inflation ${ }^{44}$. Nevertheless, although legislation ordered a review of its amount every three years, from January 1944 to December 1951 (the latter date thus falling in Vargas's new government) there would be no new raises and the minimum wage, corroded by inflation, reached its lowest value in many decades, equivalent to $40 \%$ of what it had been at the beginning of the period ${ }^{45}$.

Even so, for certain sectors of the urban economy, setting the minimum wage may have represented income gains. They were obviously dependent on their effective endorsement by employers, which is problematic in a state that has historically had meagre resources to enforce labour legislation ${ }^{46}$. In

44 Thus total inflation from 1940 to 1944 was slightly less than $57 \%$, and the minimum wage rose by slightly less than $59 \%$.

${ }^{45}$ Calculations were all made based on real minimum wage amounts found at http://www.ipeadata.gov.br. In January 1944, the minimum wage was worth the equivalent of $\mathrm{R} \$ 657$ (in Reais of July 2015). In December 1951, it was worth $\mathrm{R} \$ 260$, or $60 \%$ less.

46 As John French (2004) abundantly showed. Erickson (1979:104-105) maintains that the Ministry of Labour between 1939 and 1941, responsible for the inspection of the labour legislation and for all regulation of labour relations, spent on average only $0.9 \%$ of the federal budget. This number may 
any case, there is evidence that the depreciated value of the minimum became a reference in time, not as a minimum wage, but as a ceiling for a significant number of urban wage-earning occupations, even in industry.

In fact, the monthly average wage in 1939 for an industrial worker was 177 mil réis ${ }^{47}$. In modern industries the amount was higher: 238,4 in metalworking; 284,4 in mechanics; and 300,9 in transport material. All these industries were concentrated in the Rio-São Paulo axis. The following year, the minimum wage was set above 177 mil réis precisely for the following states: São Paulo (220), Federal District (240), Rio de Janeiro and Rio Grande do Sul (200), Bahia and Paraná (180), according to Montali (n. d.: 2). Thus, some industries exceeded the average wage effectively paid out in 1939, but not in the emerging and most dynamic sectors ${ }^{48}$. These continued to be 'detached' for a while longer from what had been decided. But this detachment, contrary to what one would expect in sectors with a scarce and specialized workforce, did not go in the direction of higher wages.

Thus, in December of 1943, the minimum wage was set at Cr\$360 in the Federal District and Cr\$340 in São Paulo (mil-réis had ceased to exist in 1942). The average wage paid in manufacturing in these two places in July of that same year

be an underestimate, since according to data from IBGE (1987:574-576) the number was almost $4 \%$ in 1939, which is still very low. There were 1.8 million contributors to some sort of social security in Brazil that year. This should be considered as the approximate size of the formal sector of the economy regulated by the state. The 160 thousand contos de réis spent by the Ministry of Labour correponded to 8,9 mil réis per person formally occupied that year, which is the approximate price of a can of olive-oil or two kilos of fat in 1937 (IBGE,1941:93). Data on social security contributors come from the same source of Graph 1.

${ }^{47}$ Calculation based on IBGE (1987:347-348, tables 7.10 and 7.12). The total wage paid to production workers that year was divided by the people with jobs and divided by 12 .

${ }^{48}$ Average wages in commerce were 420,7 mil réis in the Distrito Federal and 341 mil réis in São Paulo. Cf. Tavares de Almeida (1978:244). 
was Cr\$ 417 and Cr\$ 354 respectively, therefore, above the minimum wage of the time which had been frozen since 1940 at $\mathrm{Cr} \$ 240$ and $\mathrm{Cr} \$ 220$. The new minimum was similar to what manufacturing already paid out in average terms, and may have forced an increase of lower wages towards the new level set in these two regions. However, it is hard to demonstrate that with the available evidence ${ }^{49}$. Even so, it is highly unlikely that this increase occurred in the other states of the federation, since in all of them workers earned on average, in December of 1943, less than the state had determined as the subsistence wage, which in turn was set at a lower level than the real needs of a typical working-class family ${ }^{50}$.

Vargas would not increase the minimum wage again during the Estado Novo, and the Dutra administration simply did not follow the legislation that obliged a three year review of its level (which should have been in December of 1946). Hence, the biggest squeeze to basic wages until then and for a few more decades occurred when inflation reached 182\% between 1944 and $1951^{51}$. The consequence was a new detachment of average wages for factory workers from the artificially low amount that had been set. In fact, this was the intention of the Dutra government, which tried to nullify the role of the minimum wage

${ }^{49}$ Data with average wages in manufacturing per state may be found in IBGE (Anuário Estatístico do Brasil 1941-1945:326). See also Tavares de Almeida (1978:247). However, she presents different numbers from the IBGE one (I stick to the official numbers). The same author disagrees with Francisco de Oliveira (1972) over the effects of the minimum wage on industrial wages, maintaining that there were benefits for workers with lower wages, while Oliveira believes the minimum lowered higher wages, cautioning that average wages in industry, analysed by IAPI, were overestimated. Therefore, they were even lower than the figures transcribed here. Werneck Vianna (1999) takes Francisco de Oliveira's side.

${ }^{50}$ The destitution of the industrial worker in the Federal District during this period was analysed by Fischer (2008), among others.

${ }^{51}$ Cf. inflation data at http://www.ipeadata.org.br. 
in the regulation of the economy ${ }^{52}$. In 1949, an average wage for a worker was 835 cruzeiros per month, for a minimum wage frozen at 360 cruzeiros in the Federal District ${ }^{53}$. In spite of the enormous repression and intervention in almost all trade unions identified with Vargas or controlled by the communists (Gomes, 1988), manufacturing workers seem to have been able to partly recover their inflationary losses during the period ${ }^{54}$. But after a new policy of recuperation initiated in Vargas's second term and followed by Juscelino Kubitschek in 1959, the minimum wage was again set according to the average earned salary of a production worker, which was 6 thousand cruzeiros. Once again, a substantial number of manufacturing workers earned less than the legal minimum, and once again wages in general seem to have converged only partially to that level, exemplifying the aforementioned 'lighthouse effect' of the wage that had been set as a ceiling for a significant number of wages.

Thus, no less than $56 \%$ of urban workers earned up to one minimum wage in $1960^{55}$. Separating them by industrial sectors, one finds that $83 \%$ of employees in manufacturing, $91 \%$ of workers in civil construction, and $95 \%$ of those in extractive industries found themselves at this level, i.e., equal to or less than one ${ }^{56}$. In 1966, when the minimum wage was worth $36 \%$ less than in 1959, manufacturing wages had become detached

${ }^{52}$ An argument made by Werneck Vianna (1999) and Skidmore (2003).

${ }^{53}$ Calculation of average wage using the same methodology explained in the footnote. In the IBGE Anuário Estatístico do Brasil of 1950, the average wage paid out in July of 1949 was $\operatorname{Cr} \$ 926$, a calculation based on information from the contributors of the Manufacturing Workers Retirement and Pensions Institute - IAPI (cf. p. 328). However, this source overestimates the actual amount paid to production workers, since it also includes administrative staff. IBGE (1987) allows a separation of workers from other occupations.

${ }^{54}$ With full compensation for inflation, the average wage in the Federal District should have been of Cr\$1.150,00.

55 According to data from the demographic census, collated for this chapter.

${ }^{56}$ Ditto. In government, $65 \%$ of workers earned up to one minimum wage; $69 \%$ in commerce. 
again, but only partly: 46\% of workers from the state of São Paulo with a carteira de trabalho, $49 \%$ of workers in Rio, $70.5 \%$ of those in Pernambuco and 70\% of those in Minas Gerais (for a $53 \%$ national average) earned up to one minimum wage; $78 \%$ of formal urban workers earned up to two minimum wages ${ }^{57}$. As Oliveira (1972) asserted in his classic analysis, 'the range of earnings of urban workers is not a range, but a poor trunk with just two branches', those that earn up to one minimum wage and the few who earn more than that (ibidem). And the author added that:

The remainder of the wages that are above the minimum wage are based on the minimum as a reference point and never take into account the productivity of each industrial sector as a parameter which, set against any specific scarcity, would serve to set the cost of the workforce. The establishment of a minimum wage reinforces on a company level the global mediation that it performs in the economy as a whole: no company needs to set the supply price for a specific workforce in its sector, because it has already been set by the entire system (p. 54).

Habitually setting the minimum wage at low levels had an impact on the country's income distribution, since the social distance between the very rich and the very poor deepened over time. In 1960 , the richest $10 \%$ took $39.65 \%$ of the national income. In 1970, 46.7\%; and $51 \%$ in $1980^{58}$. This result can

${ }^{57}$ Data in Souza (1971:123).

${ }^{58}$ See IBGE (1987:75). It is income from work, as declared by people in demographic censuses. However, it underestimates the real distribution of wealth, which is certainly more concentrated than this. An experiment comparing income declared in the National Sample of Households Study (PNAD) with the one measured by the Standard of Living Study (PPV) observed that the worker's declared income underestimates the income actually earned by around 40\%. See Barros et alii. (2007). Pedro Souza and Marcelo Medeiros are working 
hardly by attributed solely to the minimum wage, but there is no longer any controversy over the fact that - especially during the military regime, when the price set was depreciated once again, in a period in which the state controlled the trade unions and again set the official policy of wage increases - the influence of the minimum wage was strong, in the sense that it shrank wages in the more dynamic sectors or, at the very least, prevented them being defined by what Oliveira called the 'specific scarcity' of the workforce.

\section{Conclusion}

It is true that the minimum wage has almost always been a simple promise of subsistence income. For a significant part of its history, it has been below this level and most workers were paid below the level set by the state. But this did not nullify its civilizing aspect, since workers were told that they had the right to a fair income. Therefore, they should fight for it, even if the state, for political or economic reasons, abstained from keeping the purchasing power of the wage it had unilaterally set. This is true of the wage that was established, the health and educational services, the retirement funds and all the other things that had become a legal right with a view to the 'elevation of the Brazilian man', thus justifying the struggle to make them effective.

Even if for a number of Brazilians the world of rights formed in the course of the Vargas era had largely remained a promise - since until at least the end of the 1960s there were never less than $50 \%$ of urban workers with jobs outside of the labour legislation - what matters for this discussion is the idea that this world of rights became an irremovable element of the

on income's tax data to show that inequality is actually much higher than apprehended by household surveys. See for instance Medeiros et al. (2014). 
horizon of expectations of the working population as the very emblem of the 'good life', as measured against a parameter of great and multidimensional socioeconomic vulnerability and insecurity: life in the countryside. For a significant number of the rural and urban masses, whose daily life and whose processes of differentiation were spontaneous, incidental, unstable, and to a large extent invisible to the state or to capital, the world of social and labour rights, or 'regulated citizenship', offered a powerful reference for the development of their individual and collective identities. Now the horizon of aspirations was no longer defined by everyone's destitution, but by the dream of personal selfimprovement through the path of labour protected by the state.

To put it differently, during most of Brazil's recent history the feeling of relative deprivation, which has had important consequences for the social dynamic in unequal societies in process of accelerated change ${ }^{59}$, did not find fertile ground because the lifestyles of the dominant and the subordinate classes were unfathomable. For the subordinate ones it seemed impossible to aspire to the position of the powerful, simply because it seemed too far away. 'Regulated citizenship', on the other hand, was within everyone's reach, if they attempted to qualify for it. This established an irresistible distinction between Brazilians from the countryside and the cities. The city became an irresistible destiny, a place of 'utopian beliefs' (Touraine, 1961) in the inclusion of social rights. This was one of the reasons for the failure of the Varguista project. It is necessary to reiterate here that it does not matter if this project was 'in good faith' or if part of the ruling elites around Vargas saw in it only a way of controlling the masses or maintaining their own political project ${ }^{60}$. It is probable that motives of this nature prompted many of

\footnotetext{
${ }^{59}$ Explored at length in Santos (2006).

${ }^{60}$ The dishonesty of a part of the ruling elite under Vargas, himself included, was asserted by French (2004) and Levine (1998).
} 
them. Nonetheless, from the perspective of the argument here what matters is that, once established, social legislation became a real object of aspiration for the masses deprived of resources and rights, simply because it was portrayed precisely as a set of legal rights, not privileges. The most recent literature on the topic is partially right in maintaining that those workers who were able to ascend to the world of 'regulated citizenship' seemed privileged ${ }^{61}$. Ideally, since this position was accessible to anyone who could get a carteira de trabalho, the privilege immediately transformed itself into legitimate aspiration, and access to it was a victory in an environment ruled by legal rights, not privileges. And this is despite the via crucis of the state bureaucratic channels for obtaining the documents that gave access to these rights. It is a new concept of the state that is at stake here. Up until Vargas the social question was unconstitutional, and the face of the state for Brazilians was the police. It is true that French (2004) is right in claiming that Vargas was just as, if not more, violent in relation to organized labour than Washington Luis or Arthur Bernardes. The social question was always combated in a bloody manner after 1935, whenever it emerged outside of 'regulated citizenship' (for example, through communist or socialist proselytizing, or through the struggle for independent trade unions $)^{62}$. By portraying itself to Brazilians as a project and a judicial system still to be implemented, the Varguista state asserted itself as the state of its nation, and not as an institution at the service of the powerful. Vargas (and I use him here as the personification of a project of state development) announced to a nation, which until then had been alienated from its state, that there was a national development project in progress and that

${ }^{61}$ Levine (1998), French (2004), Fischer (2008), and, to a lesser extent, Weinstein (1996) state this.

${ }^{62}$ As Werneck Vianna (1999) asserted, the Estado Novo began for the workers after the failed insurrection of the Aliança Nacional Libertadora in 1935. 
in it there was a place for the workers. Furthermore, at least in the apologetic discourse of order, it was a prominent place. This represented something completely new in Brazilian history, a history in which the state was built against the internal enemy represented by the impoverished, half-caste, dangerous people. Whether this was true or not, and an ideology or not, the fact is that this made the effectiveness of the evolving system an interest of those who the system said it wished to include. From that moment onwards, the struggle to put social rights into effect became a central aspect through which the state became effective in Brazil. With Vargas the workers gained a general centre of identification and, importantly, inside and within the limits of the capitalist order that the Varguista state also tried to transform. From then on, any project of overcoming the deprivation to which the workers were continuously subjected in the decades after Vargas's first term needed to compete with this solid aspiration of workers for inclusion in the realm of social rights ${ }^{63}$. The class consciousness of Brazilian workers was, for a long time, the consciousness of the right to their rights, whose effectiveness was always a process and, therefore, always and repeatedly utopian.

Another aspect that existing literature does not pay too much attention to is the fact that Vargas initiated the process (still unfinished) of the civilization of capital, by burdening it with the idea of workers as people to which they had obligations defined by law, and not as bodies which capitalists dumped unceremoniously like slave masters. To a large extent, the Varguista state burdened the indifferent elites with a mass of workers endowed with humanity and, therefore, deserving of recognition in their individuality, autonomy, and liberty. Even though Brazilian businessmen profoundly resisted putting into

${ }_{63}$ See Paoli (1988), Weinstein (1996), Negro (2004), and Santana (2001) about this. 
effect the regulation of the labour market, it forever lost the right to be indifferent. After 1945, this would be replaced by mistrust, by fear and class prejudice, but the substantial indifference in relation to the destiny of the masses, a result of the nonrecognition of the 'other' deserving of a self-referencing ' $T$ ', no longer had any place in the changing sociability.

It should be reiterated that all this occurred at the expense of the restriction of the aspirations and projects of a significant number of workers. With Vargas, organized labour had the right to form its identity, but if, and only if, this formation occurred in the sphere of 'regulated citizenship'. Through physical and symbolic violence Vargas framed the horizon of expectations and the daily life of workers. He limited them to the small-minded frontiers of capitalist sociability, by promising access to the world of consumption and the goods of liberal civilization, especially the social rights that the reformed liberalism of the 20th century added to its regulatory mix. The symbols of worker identity were now the 'model worker' (operário padrão), the 'father of the poor' (Vargas himself), and the CLT. However, although smallminded, those frontiers gave a real meaning to most people's lives, as well as reasons to fight for their effectiveness. At least until the 1980s, no political force emerging after Vargas's death in 1954 was capable of establishing viable alternative projects of identity formation for Brazilians who were solely dependent on their labour ${ }^{64} 66$.

${ }^{64}$ Only in the 1980s were these symbols effectively circumscribed by a renewed workers movement as an inheritance to be overcome. Lula, as a union leader, used to say that 'the CLT is the AI- 5 of the worker', referring to the control of unions and the collective bargaining by the state, not to the legislation on the protection of the individual worker. But the 'New Unionism' project of overcoming the Varguista legacy would be thrust aside by the neoliberalism of the 1990s, and Brazilian workers saw themselves in a situation where they had to defend the CLT and the rights that the state tried to suppress or flexibilize. I analyse these processes in Chapter IV, this volume. 
In the end, the Varguista project of inclusion through social rights revealed itself as a powerful instrument for reproducing social inequalities in Brazil. The immense migratory wave from the 1940s onwards led to long-lasting social inertia in the process of inclusion of migrants into the labour market and the social policies, which was an important restriction on the effectiveness of the Varguista promise. But the demonstration effect of a sizeable minority of upwardly mobile individual trajectories showed Brazilians that, although hard to reach, the promises of integration in the world of rights and access to its civilizational benefits were not only credible, but also possible to those who tried hard. This generated a retro-fed process that legitimated the unequal order, which was of great value in maintaining its general structure, notwithstanding the enormous social and personal costs of the persistence of inequality. 


\section{CHAPTER III \\ 'TOMORROW YOU WILL BE THE GOVERNMENT': \\ THE VARgAS'S UTOPIA IN PRACTICE ${ }^{1}$}

\section{Introduction}

From Chapter II we conclude that the inclusion of the working classes in the Brazilian social dynamic and political regime was accomplished mainly (though not exclusively) through the multidimensional regulation of the labour market. The political organization, mobilization, co-optation or control of the working classes and their labour representatives throughout history cannot be properly understood out of the framework of the establishment of legal guarantees for the individual worker and their union representatives, which gave them visibility vis-à-vis the State, assured them voice in the public arena, ensured them some relief in unemployment, while social security systems provided a social safety net for workers and for their families. In Brazil, like in other Latin American countries, the regulation of the labour market was the vehicle for inclusion under the imports' substitution industrialization model, and workers have embraced real hopes of being included in the regulatory framework guaranteed by the State. It is true that the formal labour market and its institutions have never included

The main ideas developed here appeared for the first time in Cardoso (2015b). This is a revised and extended version. 
all workers, as we have seen. Informality has been and still is large in the country. But the expectation of inclusion has always played an 'inclusive' role amongst Brazilians, especially those who fled the countryside in search for better living conditions in the urban areas after at least the 1930's. That expectation was occasionally fulfilled because of the high turnover rates that characterized the country's labour market dynamic, and this has helped to universalize the experience of a formal employment, albeit most often too short to assure enduring socio-economic security. For this reason, the formal labour market and its regulations (including the union structure) became one of the most important, if not the most important, inclusive mechanism in the country. The Vargas Era denotes this long-lasting process of subordinated, but at the same time desired incorporation of workers and their representatives in the social, economic and political arenas.

The system of labour regulation has been very stable over time in Brazil, and part of its persistence must be attributed to the fact that the labour law is constitutionalized, instituting the public authority (or the Federal Government) as a central and powerful actor in labour-capital relations. Constitutionalization has helped to consolidate a series of organized actors interested in the reproduction of the legal order, thus retro-feeding the entire system. These include the judicial system (with its hundreds of thousands judges, administrative workers and labour lawyers ${ }^{2}$ ), the Ministry of Labour (with its dozens of thousands civil

\footnotetext{
2 In 2008 the labour judicial system had 3,185 active and 2,234 retired judges; and 36,500 working and 7,708 retired judicial servants. (data in http://www. tst.gov.br/tst/iframe.php?url=http://www.tst.jus.br/Sseest/PESSOAL/ servidor/ServJT.htm, accessed in Sept. 2010). A representative of the Brazilian Lawyers' Organization estimates that one half of the more than 700,000 credited lawyers in Brazil are labour lawyers.
} 
servants ${ }^{3}$, union leaders and union administrative workers ${ }^{4}$, and so on. The constitutionalized protection encompassed: (i) formal standards for collective bargaining, including interest representation and conflict mediation; (ii) substantive rights related to working conditions, health standards, wages and many others $^{5}$; and (iii) the tutelary role of the State, which recognized the weaker position of workers in the capitalist economy, and at the same time controlled the structure, the actions and the reach of trade unions' representative role.

State regulation granted unions the monopoly of representation in a given jurisdiction (the municipality), and unions were (and still are) financed by a compulsory tax charged on all workers of that jurisdiction (the 'union tax') ${ }^{6}$. Union affiliation was not (and still is not) necessary for workers to benefit from collective bargaining results. During authoritarian periods strikes were controlled or forbidden by the public

3 The Ministry of Labour is ranked fifth in the federal budget, placed higher than Defense, Justice, Administration and 20 other ministries.

4 In 2010 the 20,800 existing unions (employers' and employees') had 176,000 formal employees, according to the Ministry of Labour. This does not include the union leaders themselves, the inclusion of which would catapult the figures to more than 400,000 people directly involved in actual workers' representation activities.

5 The regulations firstly constitutionalized in 1934 and extended in the constitutions of 1937, 1946 and 1988 include: working hours; the prohibition of night work for women and youth; minimum working age; entitlement to one day off each week; special rights for women during and after pregnancy; the definition of a minimum wage based on the basic needs of a worker's family; equal pay for equal work; salary protection; limits on overtime work; the right to housing and schooling; employer responsibility for work-related accidents and diseases; minimum occupational safety and health standards; the right of association for workers and employers; the right to collective bargaining; the right to strike; tripartite bodies for conflict resolution; labour courts; compensation for unjust dismissal; and the non-renounceable character of labour rights.

6 The tax represented one-day salary per year charged on all formal workers in the country. The resulting fund was administrated by the Ministry of Labour, which redistributed it among the unions (60\%), the federations $(15 \%)$ and the confederations (5\%). The Ministry itself retained the remaining $20 \%$. 
authority, and although State control over union actions varied intensely throughout history, collective bargaining was actually displaced in many junctures, substituted for repressive control of unions by State officials, by judicial bargaining in labour courts and also by State imposed wage policies. For these reasons, the main feature of the Brazilian labour relations' system has always been and still is the fact that the law, not collective bargaining, plays the major role in the regulation of state/labour/capital relations. Collective bargaining has been important in some crucial junctures (especially wage bargaining), but it tended to play a subsidiary role until very recently. As Noronha (2000) put it, the labour law is the most enduring feature of the Brazilian system. This feature has set the parameters for union structure and action over time.

These provisions were a direct consequence of the compromises arising from the 1930's coup d'état that fetched Getúlio Vargas into office. The program of the 'Liberal Alliance' (Aliança Liberal) for the 1930 presidential electoral campaign acknowledged the 'social question' (in the cities and the hinterland) as central to governability ${ }^{7}$, and Vargas addressed that question in his first discourse as president of the 'Provisional Government' in November 1930. One of his first acts was the creation of the Ministry of Labour to 'take care of the social question' and protect and shelter the urban and rural workers ${ }^{8}$. These intents would have to wait, of course. The legal and constitutional provisions have not gained automatic validity, for the State had seldom the willingness nor the institutional mechanisms to ensure employers' compliance (French, 2004; Fischer, 2008). The labour code was then turned into an important subject of the day to day disputes between labour and capital to make it valid in labour relations. It

Vargas (1938: 26-28).

8 Vargas (1938: 72-73). 
is not important, for that matter, that the labour law was instituted in an authoritarian, State controlled process. What is decisive is that it has shaped the expectations and practices of both capital and labour in intense and profound ways over the course of the 20th century. The law defined the issues, scope and the horizon of expectations of organized labour and individual workers in Brazil, in such a way that a good part of trade union struggles were oriented toward enforcing existing laws. In this way, workers' identities were constructed, most of the times, by the mediation of labour rights and within their bounds (Paoli, 1986; Gomes, 1988), again in different ways, depending on the historical junctures.

The institutions created in the Vargas Era were, and still are, much more deeply rooted than the then union leader Luiz Inácio Lula da Silva was prepared to acknowledge in 1979, when he said that Vargas's Consolidation of the Labour Code (Consolidação das Leis do Trabalbo - CLT) was the 'workers' AI-5', that is, the 1968's Institutional Act No. 5, the most repressive of a series of measures enacted by the military dictatorship to control and repress dissidence. As a consequence of the Act the military suppressed the habeas corpus, closed the National Congress and intervened in the Supreme Court. In practice, from 1968 to at least 1974 Brazil was in state of siege, and all individual and collective rights and guaranties were suspended. Most of the assassinations, deportations and torture of opponents to the regime occurred during this period ${ }^{9}$. Lula was not a victim of the AI-5 himself, but he was surely aware of that imagery's mobilization power when he equated it with the repressive character of the labour regulations ${ }^{10}$. He was not in position yet

\footnotetext{
9 See, among others, the excellent revised book of Ridenti (2010).

${ }^{10}$ In an interview published in July, 1978, Lula said: 'Some CLT articles are much more damaging to the working class than the AI-5. (...) To the government, it is much easier to reformulate the AI-5 than to change article 528 of the CLT' (Lula's interview to newspaper Diário do Grande $A B C$, reproduced in
} 
to recognize himself as a legitimate creation and heir of that past, and so was not the labour movement that emerged in the end of the military rule. Let me return to the Vargas's project so as to try and give a meaningful interpretation of this apparently circular fate of the Brazilian unionism.

\section{Vargas's project: a reassessment}

From Chapter II we learned that Getúlio Vargas was a virtuous (in a Machiavellian sense) political personage. He ruled from 1930 to 1945 and again from 1951 to 1954. He was the leader of a coup d'état against the oligarchic regime of 18891930 and headed the 'revolutionary' government from 1930 to 1934. A new constitution was then enacted, naming Vargas as the constitutional president. In 1937 he headed another coup d'état and became a dictator with the support of the armed forces, which were important agents of his withdrawal from power in 1945. He was elected for presidency in 1950, took office in 1951 and committed suicide in 1954 amidst an intense conservative campaign, which was escalating into another military coup. The coup was halted by the president's dramatic act, but its possibility would haunt all succeeding democratic governments until its final actualization in 1964.

Rephrasing the analysis presented in the previous chapter, the virtù of Vargas's political project was to give way to a double coordination mechanism that assured the accumulation of capital and at the same time granted workers a share in the distribution of the wealth thus produced via State-sponsored redistributive social policies. This mechanism also assured workers voice in

Grizzo et al. 1981. Quotation is from pp. 129-130). Article 528 permitted the intervention in unions by the Ministry or Labour in case of "circumstances that disturb the operation of the trade union or present relevant national security motives'. 
the political arena, both through a controlled but increasingly militant labour movement and its connections with political parties in ever more competitive political arrangements. The combination of these elements resulted in a socially ingrained political dynamic that shaped workers' economic, social and political aspirations and identities in profound and enduring ways, defining the scope and limits of the capitalist sociability in Brazil ${ }^{11}$.

To understand the operation of this double coordination mechanism, one must bear in mind the extent to which Brazilian labour law is deeply enshrined in the country's constitution. The constitutions of 1937, 1946, 1967 and 1988 have all accepted the terms of the 1934 Constitution, which first inscribed the labour code in its body. But that of 1946 inaugurated an important ambiguity, which framed the social and political struggles that followed. Let us see how it happened.

Vargas was expelled from office in 1945 by a military coup d'état, which was perpetrated to give way to the general elections which Vargas was trying to control. For reasons I cannot develop here, from 1943 onwards the Estado Novo began to lose control over various opposition agents, including students, intellectuals, the media, fractions of the Armed Forces etc. Vargas tried to control his imminent withdrawal from power in various ways: he created the two parties that would name the

${ }^{11}$ By capitalist sociability I understand the instantiation of the structuring elements of the social fabric in the day-to-day class relations under capitalism. It is the action that takes the 'other' into account as an integral set of intentions, desires and normative expectations towards 'me', concerning the world as it should be. Those expectations, however, are not the same for all actors, for capitalism is based on the unequal distribution of social, political and economic resources, in such a way that day-to-day encounters that instantiate its structuring elements are power relations at the 'end' of which the unequal distributions are confirmed, reproduced, denied or reverted, but never neglected. The capitalist sociability is the socially ingrained legitimating mechanism of the bourgeois order. I develop this at length in Cardoso (2010). 
presidential candidates in the 1945 elections; planned to be a candidate himself; planned to interfere in the composition of the Constituent Assembly to be elected in 1946, forcing himself as its innate member etc. He was deposed by a military coup in October 1945 (see Gomes, 1988; Werneck Vianna, 1999; Carone, 1988).

The Constituent Assembly gathered in 1946 was expected to burn down the pillars of the proto-fascist 'Estado Novo', the authoritarian, corporatist regime instituted by the Vargas's 1937 Constitution. But this did not happen. While condemning fascism and corporatism, the 1946 code did not derogate the CLT, either in its individual or collective rights. The 1937 Constitution had outlawed strikes and lockouts, while the 1946 one provided that strikes where free 'according to the law'. In June 1946 General Eurico Gaspar Dutra (in office from 1946 to 1950 ) enacted the Decree 9.070 regulating strikes, in practice criminalizing them much in the 1937's terms ${ }^{12}$. The authoritarian union structure created by Vargas and the detailed regulation of the labour market also remained intact. This cohabitation of a series of authoritarian regulations in a democratic institutional settlement would characterize the Brazilian labour relations ever since, and would mould workers' and their representatives' strategic action in profound ways.

As a consequence of the suspension of Brazil-USSR diplomatic relations as a result of the cold war, the Brazilian Communist Party was proscribed again in $1947^{13}$. Following suite, the Dutra government intervened in all major unions controlled by the communists and other union leaders in one

12 The Decree can be found in http://www.jusbrasil.com.br/legislacao/126565/ decreto-lei-9070-46 (visited in Nov. 2010).

13 The Brazilian Communist Party (PCB) was funded in 1922, and declared illegal in 1927. In 1945 it was legal again, and proscribed in 1947 not to return to legality until 1985. 
way or another linked to the Vargas's political project ${ }^{14}$. Besides, Dutra repeatedly postponed elections in the unions' system (Moraes Filho, 1979). Many leaders had been or would be in office for ten years or more, nominated either by Vargas's (1937$1945)$ or Dutra's ministers of labour. New elections would only occur in 1951 under the Vargas's democratic rule (1951-1954). So, authoritarian control of the labour movement marked the emerging democracy as well.

What is important for our discussion is the fact that the Dutra interventions were legal, once they were provided in the CLT. But they were ambiguously constitutional, for the 1946 national code stated that unions were free, adding that the law would regulate their constitution and practice. The ambiguity of the constitutional provisions inaugurated a process of legal, judicial and political disputes around the definition of the workers' collective rights that would continue until the 1964 military coup. Moraes Filho (1979) analyses laws, decrees, parliament debates and jurisprudence that prove the point from the legislation point of view. But this is only a symptom of a larger political dynamic that has shaped the system's overall identity, consolidating the coordination mechanism I am proposing here.

When the Dutra anti-labour government ended and prolabour (Vargas from 1951 to 1954 and Jango from 1961 to 1964) or relatively neutral (Juscelino Kubitschek from 1955 to 1960 and Janio Quadros in 1961) governments took office, the corporatist union structure proved to be a powerful tool in the hands of militant union leaders ${ }^{15}$. Contrary to the 'classic' interpretation

\footnotetext{
14 The literature on the matter is increasing in recent years. See Motta (2002), Ferreira and Reis eds. (2007); Ridenti and Reis eds. (2007), Santana (2012).

15 A good measure of the anti or pro-labour practices of different governments are the number of interventions in official unions. According to Erickson (1979: p. 67-8), the Dutra government perpetrated 219 interventions. Under Vargas' second term there were 7 interventions, 35 under Kubitschek (19551960). There is no information on interventions for the 1961-1963 period, but
} 
of the period ${ }^{16}$, in many sectors grassroots participation was the norm, not the exception (Nogueira, 1990; Negro, 1999). In this process, the banned communists and other proscribed or repressed political militants would pragmatically combat the repressive union structure while at the same time competing for its control via elections. Once winning official unions' elections, left-wing militants would virtually close them to any possible competition, and a good part of the militants' energies were devoted to winning and keeping control over official unions. The Ministry of Labour was the single constraining power to militancy, and an important one, but after 1951 labour ministers were seldom explicitly anti-labour ${ }^{17}$.

Vargas thought that organized labour would sooner or later 'be the government'. In the First of May 1951, in a public discourse at the Vasco da Gama stadium, in Rio de Janeiro, he exhorted workers to 'unite and gather in your unions as free and organized forces. The authorities will not be able to curtail your freedom, neither use pressure nor coercion. The union is your fighting weapon, your defensive fortress, your instrument of political action. Presently, no government will survive or have an efficient power to implement its social policies if it does not have the support of the workers' organizations' (Vargas, 1952:

in 1964 and 1965 the military intervened in 761 (or 37\% of the 2,049 existing) workers' unions (last figures in Martins, 1989: p. 75 and 100). Interventions were concentrated in São Paulo, Rio de Janeiro and Pernambuco (mostly in this State's rural areas). See also Figueiredo (1978: p. 137), who offers smaller numbers (433 interventions in the $1964-65$ period) due to a more restrict definition of intervention, meaning the deposition of elected officials and nomination of Ministry of Labour's delegates to rule the union. Martins (1989) and Erickson (1979) use the statistics presented by the Minister of Labour to the National Congress in a 1965 official audience about the interventions.

${ }^{16}$ I refer to the very influential works of Cardoso (1969, reprinting an article from 1961), Rodrigues (1966), Rodrigues (1968) and Weffort (1970).

${ }^{17}$ Many of them were also willing to control unions' actions. Erickson (1979) lists the names and gives a brief profile of all ministers of labour since the creation of the Ministry in 1931. 
p. 324). The words free, freedom, weapon and action are crucial here. They are antithesis of the authoritarian union structure Vargas's dictatorship had created in 1939. In any event, he was channelling the workers' militancy to the institutional, Statesponsored apparatus. He was telling workers that this very apparatus should be 'freely' occupied and agitated by them not as a way to overcome capitalism, but as a support base for Vargas's redistributive, State-led project. He offered workers in general and workers' leaders in particular an identification project that was essentially political. Dissidence, of course, was not tolerated. Union leaders still had to get an 'ideology statement' in order to be entitled to take part in elections. That is, to be a candidate a worker had to prove he or she did not profess ideologies 'inimical to the public order' (French, 2004). The Department of Political and Social Order (DOPS), an organ created by Vargas during his dictator years, should issue the proof, the 'ideology statement'.

It is interesting to note that shortly after his election in 1951 , Vargas welcomed a group of representatives of the Union of the Federal District Journalists (Rio de Janeiro), which demanded the end the 'ideology statement'. Vargas was surprised: 'What statement is that? In my government there has never existed anything like it' (Buonicore, 2000: 31, quoting the newspaper Voz Operária). Vargas was being evasive. The statement had been created in 1939, and had kept the communists out of the union structure ever since.

But this was about to change. In the second half of 1951 the Congress passed a law derogating the statement, which was confirmed by the Senate in August 1952 and sanctioned by Vargas in September ${ }^{18}$. This was a crucial decision. Vargas

${ }^{18}$ Jorge Ferreira, author of an important biography of João Goulart (or Jango) - Varga's Ministry of Labour from Jun/1953 to Feb/1954, vice-president of Brazil from 1955 to 1960, and president from 1961 to 1964 -, attributes to him the end of the ideology statement (see Ferreira, 2011: $85 \mathrm{ff}$ ). But he 
knew that the banishment of this repressive mechanism would open the way for the actual renovation of the union structure he had rhetorically preached for in $1951^{19}$. The doors of the official union structure were finally open to electoral competition, and this would soon change the power balance within it in favour of the communists and other militants not subordinated to the Ministry of Labour.

The existing literature has not recognized the importance of the banishment of the 'ideology statement' as a turning point in the Vargas political project ${ }^{20}$. The sanction of the law may have played nothing but a symbolic role at that particular juncture, once Vargas was seeking support of left-wing forces that opposed him. But the further consequences were such that the political system at large and the Ministry of Labour in particular would soon be unable to control the labour movement.

Critique of the union structure and the CLT was part of the overall process of identity formation of the PCB's union action. From within the authoritarian union structure, the militants would gather fiduciary and institutional resources that fed their recurrent intents to build an autonomous union structure, most specially a central federation that could coordinate the labour

is mistaken. Goulart was the president of Brazilian Labour Party (Partido Trabalhista Brasileiro - PTB) and was surely aware of the debates in Congress. But he was not there when the House of Representatives approved the law in 1951 . He had been appointed to an executive position by the government of his native State, Rio Grande do Sul, and stayed there until Feb. 1952. The decision was not 'his', although he did present it as such as Minister of Labour in 1953 and benefitted from its political consequences. Buonicore (2000) offers sufficient evidence on the matter.

19 This was also a symptom of the crisis which would finally lead to his suicide in 1954. The military were already conspiring, as well as the União Democrática Nacional (UDN), the right-wing party that indefatigably combated Vargas until the end (see Benevides, 1981). By sanctioning the law derogating the ideology statement' Vargas was waving to the communists and to the left in general, seeking for their support amidst the crisis (see Delgado, 1989).

20 The exception is Buonicore (2000). 
movement in a national perspective. The General Workers' Command (Comando Geral dos Trabalhadores - CGT) created in 1962 and controlled by the PCB until its destruction in 1964, was an autonomous central federation, created irrespective of the labour law's explicit provisions forbidding inter-category organizations $^{21}$. The demand for an autonomous union structure by a parcel of the previous 1964 unionism, then, was materialized in a new organization in many respects similar to what the Central Única dos Trabalhadores (CUT) would become in 1983.

The same institutional, legal resources gave the proscribed communists a niche in which they could thrive and from which they would influence the political process. Just as the new unionists by the end of the 1980s, the communists and their PTB allies were virtually hegemonic in the Brazilian unionism at the doors of the 1964 military coup (Martins, 1989; Santana, 2001). And just as it would happen with the CUT in 1989, they were in control both of the autonomous CGT and of the major official unions, including most federations and confederations (Weffort, 1970).

Besides, the communists managed to organize workers down to the plant level. For instance, the communist-controlled Metal Workers' Union of the City of São Paulo, the largest metal workers' union in the country, had some 1,800 shop stewards when its board was sacked by the military in 1964 (Nogueira, 1997: p. 21). Since the CLT had no provisions for shop stewards, their presence resulted from union-to-firm collective agreements and it is a clear indication of the communists' grassroots militant strategy previous to 1964 , as well as of the flexible character of the labour code in a non-repressive political environment (see also French, 2010).

${ }^{21}$ The best study on the CGT is Delgado (1986). For the role of the PCB in it see also Santana (2001). 
These very brief remarks should suffice to show how flexible was the 'corporatist' union structure from organized labour's point of view. That's why I used corporatist in quotes. The overall legal system was formally corporatist, but if the government was not explicitly anti-labour, corporatism was synonym to militancy for communists, left-wing PTB affiliates or Catholic militants, Marxists not aligned with the communists and independent leaders not aligned with the Ministry of Labour. The union structure did actually structure the union's political market, but the 'ministerialistas' (unions directly controlled by the Ministry of Labour) were one amongst myriad other political and syndical affiliations. In the second half of the 1950s they were already a minority.

For instance, in 1960 a III National Workers' Congress was held in Rio de Janeiro. The identity of all participants was defined in relation to the official union structure, either opposing or supporting it. The difference was basically the strength of these positions. Left-wing PTB and PCB militants wanted the end of the control of the Ministry of Labour over that structure, but not the end of the 'union tax' and the monopoly of representation granted to official unions. And the 'renovadores' ('renovators') comprised all sorts of left-wing militants not aligned with the PCB, including Catholic militants, independent socialists and Marxists, and independent union leaders, strongly opposing the union structure. The 'ministerialistas', or 'pelego' militants allied to or directly controlled by the Ministry of Labour opposed any reform ${ }^{22}$, but were a minority force (Martins, 1989: p. 82-86) ${ }^{23}$.

${ }^{22}$ Pelego is a term used in Brazilian labour movement to name official unionists. After 1945 this meant union incumbents named by the Ministry of Labour (the 'ministerialistas') or linked to the conservative factions of the PTB. In the 1970's and 80's it designated union incumbents imposed by the military government after the interventions of 1964 onwards. And after the democratization it denotes all union leaders opposing the reform of the union structure.

${ }^{23}$ In 1983 these same strategies were present at the congress that created the Central Única dos Trabalhadores (Unique Workers Central - CUT), though 
But what were the communists and other militants fighting for? John French summarizes the picture: 'Condemned to act within the universe of fraud that was the CLT, which was stacked against workers, working-class activists and trade unionists after 1943 would in practice subvert the existing law through a fight to make the law, as imaginary ideal, real. In a Brazil where workers were drowning in laws but starving for justice, it thus makes complete sense for a gaúcho construction worker to confront the bosses with his well-worn copy of the CLT: "This is my bible" (French, 2004: 152).

Thus, the bulk of the Vargas's coordination mechanism can be restated as follows: Workers moved from rural areas to the cities in search for better living conditions. Especially after 1950, there they found State-protected jobs and a militant labour movement demanding the effectiveness of existing provisions for employed workers, and extension of those provisions to ever larger proportions of the working class, as well as a better place for workers both in the emerging democracy and the capitalist distribution of wealth. The restricted scope of the formal labour market and the employers' resistance to comply with the law has made a promise of all this, but for most workers a credible one, capable of feeding their desires and aspirations. The credibility of the whole system was assured by the labour movement's ability to make of labour rights the boundaries of its collective identity, which means that the very identity of the system was the production and reproduction of a project of the universal inclusion of all workers in the dynamics and benefits of 'organized capitalism'. The struggle for the effectiveness and efficacy of the legal social rights instituted by Vargas gave stability to the project, since the rights were embedded in the Constitution and thus worth

under different denominations, except for the PCB militants, now allied to the 'pelegos' against any reform. The new unionists were the 1980's 'renovadores', now a hegemonic force. 
fighting for. It also made of the labour movement a central element in the consolidation of the Brazilian (restricted) Welfare State. And these were the very boundaries of Vargas's political project to give capitalism a legitimate, institutional, competitive, and State-controlled framework of development, the reality of which depended on workers' willingness to organize and act to make it real.

\section{Authoritarianism confronts the Vargas Era}

The civil-military rule of 1964-1985 would test the strength of the inclusive mechanism created by Vargas in unexpected ways. The authoritarian regime again banned the communists, silenced the labour movement and reinforced the dormant repressive features of the corporatist union structure (including the 'ideology statement'), and adding new ones. Some 760 interventions in unions took place in 1964-65, and the vast majority of the militants in unions with more than 1,000 affiliates were simply sacked, while many of them (especially the communists) were sent to prison (Martins, 1989).

However, strict and violent as it was, control over the labour movement was never totalitarian. Elections were never totally banned, as had occurred under Dutra. They were surely controlled, and divergence from the 'revolution's' aims was formally not tolerated. Nonetheless, in 1968 a series of strikes in the São Paulo and Belo Horizonte metropolitan regions showed that there was fire beneath the ashes ${ }^{24}$. The official unions were under control, but militancy was not, or not completely. There appeared to be room for a renewed, autonomous unionism growing outside the grids of the State controlled corporatism.

${ }^{24}$ These crucial strikes were studied, among others, by Weffort (1972), Neves (1995) and Negro (2004). 
And again, the 1968 Institutional Act No. 5 (AI-5) opened new avenues for the implacable repression against dissidence. As already noted, the AI-5 allowed the military to suppress the babeas corpus, close the National Congress and intervene in the Supreme Court. This left little place for any union action at all except, once again, controlled elections. But elections, even when controlled, are energetic moments. They mobilize strategic discourses in search for adherents, motivate part of the rank and file, involve actual voting procedures and open the way for dissidence, if this is intelligent enough to grow unnoticed to the panoptic but often myopic eyes of authoritarian rulers. One cannot explain the 'new unionism' without immediate reference to this subterranean process of militancy building under the military regime (Negro, 2004, esp. 279 ff.). Lula was elected for the first time in 1969 for a secondary position in the São Bernardo's Metal Workers Union (in the São Paulo Metropolitan Region), and again for its directing board in 1972, becoming its president in 1975 at the age of 30 . Most new unionist leaders were already in office in presumed military-controlled unions. Many others were competing for the leadership of existing unions in 'controlled' elections against military-nominated union bureaucrats, and some of them would succeed ${ }^{25}$.

It is of no minor importance that these new militants could thrive within and despite the military regime's control over unions. A good part of them had close connections with the Catholic Church's 'Pastoral Operária' and its 'Theology of Liberation'. In fact, if the Catholic Church had played a crucial role in the 1964 coup d'état, supporting the military and the conservative anticommunist wave that led to it, it was also crucial in the resistance to the dictatorship when it hardened the repression against

${ }^{25}$ For the role of the 'oposiçoes sindicais' (organized opposition to official unions) see Sluyter-Beltrão (2010), Antunes (1988), Nogueira (1997), Cardoso (1999b) and Negro (2004). 
opponents. The Church harboured dissidents, organized workers in its 'pastorais', preached against assassinations and torture, deepened discourses and practices of its 'Theology of Liberation' and its 'option for the poor', students' movements were given safe places to organize their local or national congresses etc. 'The Church' here is an euphemism, of course, for this institution was never a monolithic ideological block, and part of its leadership organized official First of May (Labour Day) celebrations in conjunction with the military while combating communism in its homilies (Negro, 2004). Dominican monks were amongst the most energetic anti-dictatorship militants, and many would face torture, exile and death (see Ridenti, 2010: 146 ff. and passim). And in many junctures the National Confederation of the Brazilian Bishops (CNBB) have made public its positions against the dictatorship's violence and arbitrariness ${ }^{26}$.

After the AI-5 public meetings and gatherings were virtually forbidden, but the Church's events were not. Within temples or in events coordinated by the Church many left-wing militants, most of which belonged to myriad Marxist groups that dissented from official communism, could gather and 'keep the flame burning' while waiting for more auspicious circumstances ${ }^{27}$. Their survival as militants within the union structure must also be taken into account in the explanation of the rapid reorganization of the labour movement after 1978. Official unions would again be the vehicles of the union structure's renovation ${ }^{28}$.

${ }^{26}$ Catholic militants were central to the 'new unionism' and to the decision to build a new political party. See Keck (1992), Löwy (2007) and Martinez (2007).

${ }^{27}$ Not all Marxist dissidents of communism joined the armed resistance to the dictatorship. Many fled the country before being forced to, others would adopt different names and occupations (many would get a manufacturing job), others would occupy the union structure etc. See Ridenti (2010), Karepovs and Leal (2007).

${ }^{28}$ It was probably Leôncio Martins Rodrigues (1989) who first called attention to this particular feature of the rapid reorganization of the labour movement after the strikes of 1978 . 
In any event, the control of the union structure by the military and the repression of the workers' movement disrupted the Vargas's coordination mechanism. It is true that the Brazilian economy boomed in the period. From 1968 to 1976 the mean annual GDP growth rate was of $10.1 \%$ (with a peak of $14 \%$ in 1973). The ideological climate was one of 'The Great Brazil', 'Brazil: Love it or leave it' and 'Go ahead Brazil!'” . In 1976, $60 \%$ of the urban occupied labour force were in the formal sector (comprising private salaried workers, civil servants and self-employed workers contributing to social security), while in 1960 the rate was below 45\%. The promise of formal inclusion seemed credible still. Rural workers continued to migrate to the cities in ever higher waves in search of better living conditions, but found nothing but low salaries, authoritarian work regimes ${ }^{30}$ and silenced unions, now specialized in providing health and legal services to their affiliates (Rodrigues, 1966) instead of fighting for a project of redistribution and citizenship. That is, in spite of the ideological climate and the frantic responses to the economic boom, for most migrant workers the possibility of access to the labour and social rights linked to the formal labour market was an illusion rather than a credible promise. The increase in productivity and wealth was not transferred to wages. The mean minimum wage was equivalent to $\mathrm{R} \$ 654^{31}$.

${ }^{29}$ Free translations of 'Brasil Grande', 'Brasil: Ame-o ou deixe-o', 'Pra frente Brasil!', some of the various themes of official authoritarian propaganda which also included 'A developed people is a clean people', a wide educative campaign teaching people not to through waist on the streets...

${ }^{30}$ One of the best studies on the authoritarian work regimes in the auto industry in the 1970s is Humphrey (1982). The author combats the argument that autoworkers were a work aristocracy, as sustained by part of the literature on the 1978-79 strikes. On the same lines, Abramo (1999) is a classic analysis of those strikes as a fight for dignity at work.

31 According to IPEA, a research institute linked to the Ministry of Planning from which these data are withdrawn, considering the parity of purchasing power (PPP), the minimum wage was of US\$61 in 1976. Data can be gathered at www.ipeadata.gov.br by adding ‘salário mínimo’ in its search engine. 
In 1976, 30 per cent of the urban occupied labour force earned less than one minimum wage. Sixty per cent earned less than 2 minimum wages ${ }^{32}$. At least $80 \%$ of workers in garment and textile industries earned 2 minimum wages or less ${ }^{33}$.

The minimum wage was a central element of the military restrictive wages' policy, but not the only one. In 1966 increases in contractual wages in the private sector began to be defined by the government based on estimates of future inflation that would actually become underestimates. Workers' leaders who demanded increases above the official level could be legally laid off and even imprisoned based on the 'Law of National Security'.

Besides, employers could evade the labour law without retaliation either from unions or the State. In that respect, the military succeeded in disrupting the legitimating, political moment of Vargas's mechanism, substituting it with sheer repression. At the same time, the military restricted and most of the time forbade the struggle for the effectiveness of labour rights, thus narrowing the boundaries of workers' inclusion in the capitalist dynamic to the operation of the brute force of the labour market. This created tensions that were at the very core of the authoritarian regime's dynamics, and helped exert pressure on its repressive frontiers in the very moment a fraction of the military elite decided to prepare its withdrawal from power ${ }^{34}$. This, I argue here, explains the regime's inability to respond to the 'new unionism' when it became a mass movement of demand for better salaries and working conditions. And the mass character of the 'new unionism' cannot be explained without mentioning the regime's repression of the workers' demands for

${ }^{32}$ For CLT provisions forbidding actions against economic policies, see Figueiredo (1978). For the minimum wage, Chapter 2 in this volume.

${ }^{33}$ All data on labour market and income processed from PNAD-1976 microdata.

${ }^{34}$ For the fractions in the military elite as part of the will to open the regime, see, among many others, Stepan (1986), and O’Donnell et al. (1986). 
the effectiveness of labour rights - in particular, recovery of the purchasing power of wages.

\section{The 'New Unionism' and the Vargas Era}

In July 1977, public opinion was harnessed by the unveiling of the forgery of 1973's inflation index by the military regime. As I said, in 1966 the regime had imposed a restrictive wage policy that defined wage increases based on a fraction of past inflation and on an estimate of future price indexes. Official 1973 inflation figure was of $15.5 \%$, but other sources found $20.5 \%$ based on alternative data. The DIEESE (Inter-union Department of Statistics and Socioeconomic Studies), a labour movement institution created in the mid 1950's, computed its own price index (the Living Cost Index - ICV) for the São Paulo Metropolitan Region. After the announcement of the official 1973 inflation index the DIEESE immediately contested the figures, but Brazil was at the apex of the military repression with most media under severe censorship, and this had no effect. In 1977 the São Paulo City Metal Workers' Union started a campaign to make public the DIEESE's index. A secret World Bank report to the government sanctioned this index, and parts of the report were finally published by the newspaper Folha de S. Paulo in July 31. An investigation carried out by the labour justice in the IBGE (Brazilian Institute of Geography and Statistics, responsible for the official price indexes) files in 1977 apparently found records with fraudulent interventions on the original 1973 surveyed prices, but this has never been proved ${ }^{35}$.

The São Bernardo Metal Workers' Union asked DIEESE to estimate the wage losses due to this fraud, and the union's

${ }^{35}$ For media censorship during the military rule, see Dassin (1978) and Soares (1989). For the 1977 and 1978 bargaining and strikes, see Rainho and Bargas (1983: 39 and ff.). 
1977 wage bargaining demanded a wage increase of $34.1 \%$. The campaign was not successful, for in November 1977 the labour court arbitrated an increase based on the official wage policy methodology. But it showed that the union was not dead. In May 1978 workers of the Scania Truck assembly plant in São Bernardo do Campo began a strike demanding a supplementary wage increase of $11 \%$, and the movement spread to the entire metal workers' belt of the São Paulo Metropolitan Region, and from there to other 6 Brazilian States and thus to the entire country $^{36}$. The labour movement was back in the scene.

Workers joined in mass mobilizations in spite of the violent repression that came about, and the mass character of the movement made repression ever more costly and unpopular. Dignity at work, distributive justice, fairness in work relations, better work conditions were central issues in the process of the identity formation of the 'new unionism' (Abramo, 1999). This was also a crucial aspect of the novelty of the emergent collective movement.

It is true that the novelty of the 'new unionism' was constructed against a very simplified (and incomplete) version of the Vargas's coordination mechanism. The alter of the 'new' was a pattern of union action which the prevailing literature had characterized as corporatist, State controlled and devoted to political, not collective bargaining ${ }^{37}$. According to this perspective, and contrary to what we have just seen, unions lacked effective control over their constituencies, had no plant level penetration,

\footnotetext{
${ }_{36}$ See also Keck (1988: 395-404).

37 The literature on the matter abounds. Prominent and very influential arguments are those of Weffort (1970), Rodrigues (1968), Rodrigues (1966), Schmitter (1971), Erickson (1979), and Collier and Collier (1991). Strong critiques are Paoli et al. (1983), Paoli (1988) and Gomes (1988). A step further was proposed by Santana (1998) and French (2004). The latter names this the 'corporatist consensus'. A multidimensional revision may be found in Rodrigues ed. (1999). The literature on populism was criticized by Ferreira (2010).
} 
were ineffective in collectively bargaining working conditions and were dependent of the State for wage bargaining. They were also controlled by political parties and served the parties' (not workers') interests as intermediaries in mass-manoeuvring the disorganized workers in populist political arrangements, and derived their legitimacy from this connection, not from direct, autonomous representation of workers' interests. For most of this literature the CLT had a 'narcotic' effect on union action: On the one hand, it assured union survival irrespective of the number of affiliates, because of the 'union tax'; on the other hand, it regulated work contracts in a way that made collective bargaining unnecessary ${ }^{38}$. Union leaders had pragmatically relinquished their autonomy by adhering to the CLT benefits, which freed them to act as political, not union leaders.

The 'new unionism' was viewed as the opposite of all that $^{39}$. Most of all, it was autonomous vis-à-vis both the existing political parties and the State repressive apparatus, the two main control mechanisms of the previous 1964 era. Its main leader, Lula, would repeat that the CLT was the workers' AI-5, and that it should be completely banished. In his words, this would finally bring down the Vargas Era, totally renew Brazilian unionism and modernize the country's labour relations ${ }^{40}$.

This dichotomous interpretation is no longer sustainable, of course. A vigorous new labour historiography has put the events of the 1980s in perspective, and the 'new' emerged as heir

38 The idea of a 'narcotic effect' of the union structure is in Cardoso (1969, republishing a paper of 1962) and is repeated by Rodrigues (1966) and Rodrigues (1968).

39 An important and influential statement of the novelty was proposed by Tavares de Almeida (1983).

40 This approach led an important analyst of the Vargas Era to immediately acknowledge the new unionism's modernity. Its main feature would be the denial of traditional, electoral politics and the proposition of a project of political mobilization anchored in civil society. See Werneck Vianna (1991). 
of a multidimensional and complex past. From this revision's standpoint, neither the 'old' was that old, nor the new completely novel ${ }^{41}$. But it is my view that revisionism has gone too far. In many respects the 'new unionism' was actually new. First of all, thanks to the military regime the previous left-wing political elite had been virtually wiped out of the political arena by 1978 . Those who had survived in the exile would return in 1979 amidst the effervescence of the anti-military movements headed by the 'new unionism' 42 , and they had to cope with a social force over which they had no institutional power, little political influence and about which they knew little or nothing. Most of all, this social force was building its identity as new against that of a parcel of the returning militants, who were blamed by many for the failure of the pre-1964 democratic experience ${ }^{43}$. The CUT was created in 1983 opposing the remaining communists and old 'pelego' bureaucrats, thus establishing a clear-cut with past labour movement militants.

Secondly, the working class was also new. In 1978 most of 1964 workers had already retired or were considered too old in an urban labour market that had to open room for two million or more new entrants every year as a result of migration and natural population growth (Faria, 1983). New unionists were young themselves. Lula and the prominent oil workers' leader Jacó Bitar, two major new unionist militants, were both around 30 years old. Bank workers union directors (such as Gilmar Carneiro) were even younger, so were the leaders of the

${ }^{41}$ The strongest statement in that direction is certainly Santana (1998). See also Negro (1999 and 2004).

42 The Amnesty Act was enacted in August 1979, after which banned figures such as Leonel Brizola and Miguel Arraes, two top PTB leaders, and Luis Carlos Prestes, Giocondo Dias and other communist top figures would return to Brazil.

43 The strongest argument blaming the communist-populist strategies for the military coup is Weffort (1970). The best explanation of the political causes of the coup is Santos (2001). 
São Paulo Teachers' Association (APEOESP). Many of these militants had had no contact whatsoever with the previous 'populist' or communist militants. And those were some of the most influent leaders amongst the new unionists.

Thirdly, and apart from the fact that new militants were emerging in a renewed socioeconomic environment, according to the 'new unionism' the renovation of labour relations in Brazil should include a national collective contract freely negotiated between workers' and employers' central federations, which would be created as part of a reform of the union structure that would ban the 'union tax' and ratify ILO's Convention 87 on freedom of association, among other central issues ${ }^{44}$. If accomplished, this would represent the end of a central aspect of the Vargas project, for labour relations would change from its legislated historical shape to a new contractual scenario anchored in free unions.

Indeed, the 'new unionism' did contribute to a partial but yet important renovation of the corporatist union structure while thriving within it (Cardoso 1999a). While only 14\% of all unions were affiliated to the CUT in 1989, this included all major public sector unions, both in the direct and the indirect administrations; all major unions of metal, mechanic, chemical, bank, oil, electricity, urban services, transports, not to mention the vast majority of rural workers' unions which were affiliated to a central federation, were all CUT affiliates.

${ }^{44}$ Literature on this project abounds. An excellent recent analysis of the dilemmas and difficulties faced by their proponents is Sluyter-Beltrão (2010). Some pre1964 currents preached in favour of the ILO's Convention 87 and of collective contracts in place of the CLT, but they have never been hegemonic in the union's market of political exchange. After the 1958's 'Declaration of March' (see below) the Brazilian Communist Party (PCB), now a Brazilian Labour Party (PTB) ally, would oppose any reform to put an end to the 'union tax' and the monopoly of representation of official unions in a given jurisdiction (known as unicidade sindical) (Santana, 2001). 
In the 1990's the CUT would slowly but steadily consolidate a parallel federation and confederation structure to compete with the corporatist, bureaucratic bodies ruled by old 'pelego' administrators ${ }^{45}$, thus organically coordinating the action of its affiliates. As a consequence, the new unionists would enlarge the scope of workers' rights in a wide array of economic sectors, sometimes far beyond the CLT provisions. Contractual rights concerning working conditions, safety at work, shop floor union representatives, rights to information and access to workers at the plant level, regulation of working hours, work shifts, fringe benefits such as transport, food, housing and health subsidies are among the new issues negotiated by the 'new unionism' for millions of workers, especially after $1980^{46}$.

Finally, the Workers' Party (PT) - the necessary political element that, in Vargas's double-bonding mechanism, should be responsible for the construction and generalization of a workingclass based political project of redistribution and citizenship under capitalism - was not the Brazilian Labour Party (Partido Trabalbista Brasileiro - PTB). This party had been created by Vargas in 1945 and has always been controlled by members of the capitalist elite and the urban middle classes (Benevides, 1989). Some union leaders had been PTB militants, but at least

45 The union structure designed in 1939 by the Vargas regime and still in effect is composed of local, municipal unions; federations congregating at least five unions of the same category of workers in a federated State; and confederations of at least three federations. The legal federations and confederations have little, if any bargaining power today, but they are still entitled to a share of the union tax. This has created an incentive for the reproduction of a federationconfederation system which is completely isolated from the labour movement but which has access to funds, which finance the 'pelego' leaders. This has stimulated the creation of the CUT's parallel system.

${ }^{46}$ For these issues, see Sluyter-Beltrão (2010). It is true that the communists had succeeded in negotiating similar new rights before 1964, and it is still an open question whether the larger number of workers benefiting from these rights after 1978 (a quantitative criterion) resulted from important qualitative differences in unions' actions. 
after 1954 the union market was increasingly dominated by the PCB. In March 1958 the PCB reviewed its political position and decided that the party would ally with the 'nationalist forces' of the nation to help deepen the country's economic development as a way to combat the 'Yankee imperialism' and resolve the 'structural contradiction between feudalism in the countryside and modern capitalism in the cities'. Amongst the prescribed strategies was the occupation of the union structure. In 1961 this alliance controlled 5 of the 6 existing official confederations and most of the major local federations and important unions ${ }^{47}$. In practice, the PTB became an electoral machine closely linked to the PCB's grassroots labour militancy. The PT, on the contrary, was created in 1980 by that very militancy. True, it gathered not only union leaders, but also Catholic Church activists, prominent middle class intellectuals and communist dissidents of all sorts, many of which coming from the students' movement, all of them notorious anti-dictatorship militants. But its working-class roots were clear enough (Martinez, 2007), and these would be reaffirmed by the creation of the CUT in 1983 by the very same core militant workers that had created the PT three years before.

From this point of view, the main novelty of the 'new unionism' was the proposition of a project of inclusion of workers in the emerging post-dictatorial sociability constructed from below. Its identity was also socialist, though the nature of the movement's socialism has never been clear except for its anti-communist and anti-capitalist character. A socialism built from below based on mass mobilization in the cities and the countryside, headed both by the political party (PT) and the central federation (CUT), each playing complimentary roles in bringing ever more adherents to the project, that in the process

${ }^{47}$ For the political divisions within the labour movement in the 1960-64 period, see Martins (1989) and Erickson (1979). 
would shape the nature of their socialism: this was always the proposal of leaders such as Lula in 1980 and Jair Menegheli (president of the CUT from 1983 to 1994). In this respect, the 'new unionism' was certainly another intent to overcome the boundaries of Vargas's coordination mechanism, now from below, since the identity of workers' movement was shaped against and in opposition to capitalism and its State, contrary to Vargas's project of giving a State-organized capitalism a legitimating mechanism.

\section{Vargas and neoliberalism}

All that notwithstanding, the 'new unionism' would renew the coordination mechanism of the capitalist sociability in Brazil in a way that would certainly appeal to Vargas. The Workers' Party would soon win elections in important cities and States, and its socialist discourse had to face the challenges of the practical administration of a peripheral and poor capitalism. Restricted public budgets in a highly inflationary economy expanded workers needs beyond the State's ability to address them ${ }^{48}$, and the PT administrations would sooner or later confront the CUT, especially its public sector affiliates ${ }^{49}$.

On the other hand, and again very unexpectedly from a 1980's perspective, in the 1990's a good majority of the new unionists would become resolute supporters of the CLT and the major institutions of the Vargas era. One of the main reasons for this, as I show in Chapter IV, is the fact that in Brazil as well as in

\footnotetext{
${ }^{48}$ PT's first decisive electoral achievement was in the 1988 elections for the council of cities such as São Paulo, Porto Alegre, Vitória, all capital of their respective States, and of São Bernardo do Campo, Campinas and a few others in the State of São Paulo, the party's cradle. In 1985 it had won the elections in Fortaleza, capital of Ceará.

49 An important study on the PT's trajectory and its (sometimes turbulent) relations with the labour movement is Ribeiro (2008).
} 
most Latin American countries, neoliberal policies undermined the main pillars of the workers' movement. Fernando Henrique Cardoso was elected in 1994 with a modernizing discourse, the backbone of which was again the erasure of the 'Vargas Era' (as had been Fernando Collor de Mello's, for that matter ${ }^{50}$ ). Structurally, employment in manufacturing, banks, state-owned companies and public sector at large shrank dramatically as a direct result of those policies. From 1988 to 1998, 1,7 million formal jobs were lost in manufacturing, 500 thousand in finance, 450 thousand in privatized State companies (Cardoso, 2003: 228-31). At the federal and provincial levels, near 300 thousand jobs in the direct administration were lost, and if we consider the three administration levels (federal, provincial and municipal), more than 900 thousand jobs were destructed. Formal employees are the clienteles of unions in Brazil, for they represent registered workers only. Considering the entire economy, the loss of registered jobs was of almost 2,4 million, and 8 out of every 10 new jobs created in the period were informal ones, thus lying outside the reach of the labour movement. The formal labour market shrank from 56\% to 40\% from 1990 and 1999 (idem: 42-43).

Rising open unemployment rates (from 4\% in 1990 to $8 \%$ in 1999) reduced workers' bargaining power, unions lost funds and capacity for collective action and grassroots mobilization, collective bargaining became concession bargaining, real wages fell nationwide, constitutional labour rights related to working hours, wages and types of labour contracts were flexibilized, etc. ${ }^{11}$ New unionism's proposed renovation of the Vargas Era

${ }^{50}$ Collor was elected president in 1989 against Lula. He too had a radical, anti-'Vargas Era' neoliberal project, but could not implement it for he was impeached in mid-1992.

${ }^{51}$ For the Latin American case, see Cardoso and Gindín (2009), and also Cook (2007) and Berg et al (2006: 167 ff.). 
from below was hit by market forces that the State had unleashed but which the labour movement could neither control nor tame. In this insecure scenario, the labour law appeared to most union leaders as something worth fighting for, and even the proposed reform of the union structure was put on hold. In a neoliberal, catastrophic scenario, the ILO's Convention 87 sounded like an invitation to organizational suicide. The official union structure was turned into the trench from which workers' leaders would try to survive neoliberalism.

Cardoso's was surely the most systematic attempt to put an end to Vargas's coordination mechanism. Neoliberalism depoliticized the economy and tried to implement a new coordination and cohesive mechanism: market efficiency topped up with liberal democracy. A minimal State, the market as the main regulation mechanism, weak unions and social movements, and the vote as the exclusive instrument of individual participation were all antipodes of the project of nation-building based on State-led capitalism, with some sort of social inclusion via redistributive social policies anchored in workers' organizations and social movements. No wonder that the 1990s would surprise the new unionists fighting for the effectiveness of the CLT (then subject to flexibilization policies ${ }^{52}$ ) while competing for power at all levels of the public administration (municipal, state, and federal) and preaching against neoliberalism and for the strengthening of civil society and State institutions. Vargas's spectre was apparently back.

\section{The Vargas's spectre}

After a purely left-wing coalition put together for the federal electoral campaigns in 1989 and 1994, in 1998 the PT

$\overline{52}$ I analyse this extensively in Cardoso (2004). 
and its traditional left-wing allies opened their coalition to leftcentre forces, and in 2002 it won the national elections with a wide centre-based coalition. However, in spite of its clear procapitalist shape, this coalition had to fight a strong confidence deficit during the presidential campaign, since in the 1990s the PT and its social movement allies had become the hegemonic actors in the anti-neoliberalism political faction. In 2002 Brazil was at the doors of bankruptcy due to the failure of neoliberal rationale. I don't have the space to go through this here, but in January 1999 Brazil had to devaluate its currency after a series of crisis that had shaken Asia and Russia in 1998. This sealed Cardoso's fate, for he had won the 1998 elections against Lula promising not to devaluate. Brazil had spent some 40 billion dollars (from an IMF loan) in 50 days trying to secure its currency, to no avail. The years of the second Cardoso's term were of rising inflation, unemployment, public debt and State fiscal crisis, while real wages kept on falling ${ }^{53}$. In face of the crisis, Lula had to make public a 'Letter to the Brazilians' in which he defended the main pillars of the on-going macroeconomic policies to prevent speculative attacks on the country's fragile economy. Central Bank independence, fiscal austerity, inflation targeting and currency stability, that is, macroeconomic neoliberal orthodoxy, would all be maintained in the new administration. The critical socioeconomic circumstances had apparently forced too strong a move to the centre of the political spectrum, away from a project of State-led social transformations that had been the core of the PT's political identity - away from Vargas.

However, once elected the new government would bring about a vast array of new concertation mechanisms. Organized labour and organized civil society were brought into play in the

${ }^{53}$ By the end of 2001 the neoliberal government was approved by no more than $18 \%$ of the population (Cardoso, 2003). 
new government. The Landless Workers' Movement (Movimento dos Trabalhadores Rurais Sem Terra - MST) became a strategic interlocutor of the Ministry of Agrarian Reform; the Ministry of Labour was headed by the CUT, its union leaders and technicians; the Ministry of Health was occupied by egresses of the health workers' movement that had been present in the very birth of the Workers Party as one of its major middle class factions (along with academic organizations of all sorts); former new unionist labour leaders were appointed to offices in strategic state owned companies, such as Petrobras (oil production), Furnas (electricity production), Bank of Brazil, Embrapa (Brazilian Company for Agrarian Research), Eletrobras (electricity) and many others. The new unionism had finally accomplished Vargas's 1954 premonition. In a discourse directed to workers in the First of May, weeks before his suicide, he would perhaps rhetorically say that 'today you are with the government. Tomorrow you will be the Government' (Vargas, 1969: p. 473, emphasis added).

If the macroeconomic neoliberal rationale was shielded away from the political battles, substantive aspects of the policy making were not. It is true that PT and CUT have abandoned their strict socialist discourses, but the consequence of these participatory decision-making processes was the implementation of a project of universal inclusion in the capitalist dynamics via amelioration of the living conditions of the poor, and mass inclusion of lower middle classes and poor strata in the consumption market through subsidized credit mechanisms, redistribution of income ${ }^{54}$, economic growth and, most

\footnotetext{
54 Two main mechanisms of redistribution were created. The 'Bolsa Família', a minimum income's policy for families with per capita income of less than one dollar per day (now reaching some 40 million individuals); and real increases in the minimum wage, which affected the income of some 16 million households. The redistributive consequences of these policies are measured by Soares et al. (2006), Soares (2011) and Rocha (2012).
} 
importantly, employment creation ${ }^{55}$. All this was achieved under strict macroeconomic stability measures aimed at controlling inflation. The combination of these elements was a complete novelty in Brazil, since mainstream economic wisdom has traditionally sustained that growth is inflationary, and so are income's policies ${ }^{56}$. This project, it should be emphasized, met the expectations of most Bragilians ${ }^{57}$, and does explain most of Lula's success, especially in his second term (2007-2010).

But popular support for successful inclusive policies was not the whole of it. From the perspective proposed here, the inclusion of organized society in many core federal administration agencies has distinguished Lula's government in crucial ways. True, under Lula organized labour has become 'the government', thus fulfilling Vargas's 1954 premonition. But this does not mean that the Vargas project has finally come true. Workers have become 'the government' not as a result of direct working class mobilization by strong unions as envisaged by Vargas. In 2002 the formal labour market harboured not more than $55 \%$ of salaried workers (which means that $45 \%$ were not protected either by collective bargaining or the labour law), and union density was $19 \%$ of the salaried workforce, the decline a direct result of Cardoso's neoliberal policies (Cardoso and Gindin, 2009). In many respects, workers' access to State power

${ }_{55}$ During the Cardoso period, 8 out of 10 jobs created were informal. From 2003 to 2010 , the equation was reversed, and 15 million formal jobs were created, a record in Brazilian history. See Neri (2010).

${ }^{56}$ A good recent analysis of this wisdom is Wanderley Guilherme dos Santos 'Lula e sua herança', in http://www.cartacapital.com.br/politica/lula-e-suaheranca.

${ }^{57}$ In Oct 2010 president Lula was approved by $85 \%$ of the Brazilians, while $77 \%$ evaluated his government as good or very good. See http:/ / oglobo.globo. com/pais/eleicoes2010/mat/2010/10/01/avaliacao-do-governo-lula-baterecorde-diz-ibope-922675872.asp (visited in Jan. 2011). 
was achieved while the workers' movement was in its nadir ${ }^{58}$. Lula was an offspring of it, but the movement alone would never guarantee his electoral success.

Besides, Brazil had become a mass democratic society opened to the vote of all citizens 16 years or older. The PT had certainly become the main electoral machine of organized civil society, from which most of its militants were recruited (Ribeiro, 2008). No other political party in Brazil had ever achieved that in scope and depth, but the 2002 coalition would not have won the national elections were it not for the support of the other, 'disorganized' voters: housewives, retirees, students, salaried and self-employed workers that remained outside the reach of the labour law. Most of these social categories were not included in the political process in the 1950s and were certainly not envisaged by Vargas as potential voters ${ }^{59}$. They were not a direct consequence of the Vargas institutional machinery. What were all these people voting for when they decided to support a political coalition the project of which was unclear from the start?

On the one hand, the resounding failure of strict neoliberalism opened way to oppositional projects, and the PT and its allies were the incontestable hegemonic anti-neoliberal forces. They were an obvious electoral option. On the other hand, P's's political discourse and previous administrative practices were based on an overarching ideal of social solidarity, citizenship and social justice that apparently seemed credible to the majority of voters. Its proponents had an identifiable history of struggle, whether in civil society or in office in cities and

\footnotetext{
${ }^{58}$ During Cardoso's administration the annual number of strikes fell from 1.000 in 1994 to 500 in 1999 and less than 300 in 2002. See Cardoso and Gindin (2009: Graph 4).

${ }^{59}$ Brazil had near 50 million inhabitants in 1950, and 15 million registered voters (or 30\% of the population). In 2000109 million out of 170 million Brazilians were voters (or 64\%). Data in www.IBGE.gov.br.
} 
States $^{60}$. Rebuild the State, reconstitute the social fabric, bring solidarity back in: this was the core of Lula's campaign discourse in $2002^{61}$. All this certainly resonates with the Vargas project. But the Vargas world had actually been left far behind. I will end with some brief remarks on the topic, central to the understanding of the nature of the Vargas coordination mechanism.

\section{Conclusion}

The 'new unionism' has finally fulfilled Vargas's forecast. Workers have become 'the government'. Lula has impersonated the trajectory of the poor rural migrant that comes to the city in search of better living conditions and finds a formal job and a State-controlled channel of political participation. From this protected realm of the country's evolving capitalism (the formal labour market and its regulatory institutions, unions included, all of which part of Vargas's coordination mechanism) he has headed the construction of a political party that has slowly become hegemonic in the left-wing political spectrum with a bottom-up project of erasure of the 'Vargas-era'. This project was not one of a renewed capitalist sociability. The aim was a socialist society, loosely defined as 'socialism' may have been from the beginning. The socialist project was finally (and pragmatically) abandoned in favour of a political program based on solidarity and social justice when the PT started winning elections around the country. State power became the main target of the new unionists and their allies. Labour and social

\footnotetext{
${ }^{60}$ Two policies among myriad others can be mentioned here: the participative budget implemented in Porto Alegre by Olivio Dutra in 1989, extended to many other cities in the 1990s; and the subsidies to poor families that kept children in school, implemented in Brasília by Cristovan Buarque in the early 1990s, which was the first minimum income's policy in Brazil and set the parameters for Cardoso's 'Bolsa Escola' and Lula's 'Bolsa Família'.

${ }^{61}$ See Ribeiro (2008), among hundreds of others.
} 
movements became the cradle of new political elites, and once in office, they would occupy many of the most strategic positions of public administrations, which they obviously shared with their allies.

When neoliberalism gained momentum, this project of State-led capitalism was equated with the Vargas-era, for it was presumably sustained by elites nurtured by the 'union tax' and other 'illegitimate', heteronymous mechanisms inherited from an unwanted past. Fernando Henrique Cardoso would actually name left-wing militants 'a vanguarda do atraso' ('the rearward vanguard'), and his project of reform of the CLT was explicitly designed to put an end to those institutions. Cardoso was probably not aware that those legacies had actually bonded the capitalist sociability in stable and profound ways, making tolerable the country's social inequalities and iniquities from the workers' perspective. The wish for a State-protected job was the wish for socioeconomic security, which could open an avenue to upward social mobility and to better living conditions either for oneself or for one's children. This was a central element of Vargas's double coordination mechanism that stabilized capitalist accumulation in Brazil. Neoliberalism resulted in mounting unemployment and falling wages, to be dealt with by workers' investments in their own employability. The State was rubbed from workers' horizon of expectations and aspirations, putting nothing in its place but the market, the dominion of the fittest. This political vacuum was occupied by the PT and its allies, who were accused of trying to revive the Vargas era. When workers finally 'got there', the analogy was already set.

The analogy is misleading. It has always been used by interested parties in the political arena to label supporters of any broad or diffuse program of State-led economic development. It has been part of the ideological disputes over the destinies of the nation, and in the 1990 s modernity was a synonym for the 
market, not the State. Once in office, Lula would praise Vargas for his social policies while condemning his authoritarianism, and this added to the identity of his presidency as anti-neoliberal. In both cases the Vargas Era was a figure of political rhetoric, and served to mark positions in the political and electoral field. This is undoubtedly proof of the strength of Vargas's figure, but is there anything of substance under the surface of political marketing?

Vargas's institutional machinery is still here. The CLT still constitutes the labour market's institutional bones ${ }^{62}$. The majority of workers would prefer a formal job if they could choose. Unions are still financed by the 'union tax' and have the monopoly of representation in a given jurisdiction. The 1988 Constitution freed unions from State control, thus changing the 1939 provision according to which unions had to be homologated by the Ministry of Labour, which had legal control of union affairs, including elections, budget, expenditures etc. The Constitution provided that unions no longer had to register with the public authority. Nonetheless, because workers' and employers' organizations were still entitled to tax their constituencies - the new Constitution maintained the 'union tax' - labour courts were flooded with complaints from unions created in the jurisdiction of already existing organizations demanding access to the 'union tax'. In response to that, in 2003 the Supreme Labour Court established that the Ministry of Labour should decide which union represents which workers in a given jurisdiction. The 'spirit' of the Constitution, which was inclined to consecrate freedom of association and union autonomy from State control, was importantly reversed by the Supreme Labour Court in 2003. Since then, unions must

${ }^{62}$ After 1998 many flexibilization measures were approved in Congress by the Cardoso administration. But the overarching, protective rationale of the CLT is still alive. 
register with the Ministry of Labour again, and this authority has the power to guarantee the monopoly of representation of the chosen union (Cardoso and Gindin, 2009).

Besides, in 2008 the central federations had their project of being funded by a share of the 'union tax' approved by the National Congress. With this instrument the Lula administration has assured a stable funding mechanism for the reproduction of labour movement-based political elites. Once in government, top union leaders have pragmatically relinquished the project of reform of the CLT, since workers and social movements have become important elements of the government's capillarity in civil society. From this point of view, workers were really 'the government', and in office they were concerned with the survival of their cradle institutions, that is, the partially renovated union structure inherited from Vargas and the social movements in one way or another linked with the PT and its allies.

On the other hand, Lula and allies have brought the State back in, at least in two important ways. First, the PT administration has partly re-politicized the economy. The neoliberal macroeconomic orthodoxy was still shielded from political disputes, but the State has become a central engine of economic growth by directly investing in infrastructure and financing private investment with subsidies of all sorts. This was possible because Brazil has its National Bank of Economic and Social Development (BNDES), created by Vargas back in the 1950s, which has been the main instrument of the government's rapid response to the 2008 subprime crisis. The bank financed employment policies, private and infrastructure investments and company mergers with subsidized interest rates ${ }^{63}$.

${ }^{63}$ BNDES' main resources come from the Workers Aid Fund (Fundo de Amparo ao Trabalhador-FAT), a contributive fund charged on private companies which finances unemployment insurance and the wage bonus (every worker earning 2 
Secondly, the State was again the main means of coordination of the capitalist sociability, a role neoliberalism had tried to hand to the market. This is not pure political rhetoric. By offering the population at large a credible project of socioeconomic inclusion and security, and by struggling alongside opposition forces to implement it, the State has once again fed workers' expectations and aspirations. This has again bonded the fate of the Nation with that of its population, thus giving capitalism a smooth pathway to thrive. President Vargas was the first to incarnate this project in Brazil. Lula has been its most recent impersonation. And the majority of the Brazilians have approved it.

The Vargas machinery was an encompassing political project of nation-building and consolidation of the bourgeois order, which gave workers a solid institutional trench from which their leaders could thrive and find their way in the political arena, while struggling for better living conditions in the present. The machinery is still vivid and active, for workers still dream about a formal job, and union leaders still take the CLT as an important parameter of their collective action. But the horizon of the workers' movement in no longer limited within the borders of the labour code. Workers' leaders are now facing the challenge of administering the capitalist State much beyond the needs and boundaries of the world of work. And this was certainly envisaged by Getúlio Vargas back in the 1950s.

minimum wages or less is entitled to one Christmas minimum wage bonus per year). See Cardoso Jr. et al. (2006). 


\author{
CHAPTER IV \\ NeOliberalism, UniOns, AND \\ SOCIOECONOMIC INSECURITY ${ }^{1}$
}

\title{
Introduction
}

The 1980s were dramatic for the labour movements in advanced, Western capitalist countries (Visser, 1993; Western, 1997; ILO, 1997; Foster and Scott, eds. 2003). ${ }^{2}$ Strikes, union density, the scope of collective bargaining and other indicators of unions' power fell not only in the West but in other parts of the globe as well. However, Brazil was a clear exception to this trend, as the 1980s represented a decade of efficiency and efficacy of the labour movement organizational and representational action. After the rebirth of trade unionism in the manufacturing region of the São Paulo Metropolitan Area in 1978, the number

1 Published for the first time in Labour, Capital and Society Vol. 35, No. 2, Nov. 2002, pp. 282-316. The original article was only slightly revised for this publication.

2 I would like to thank the following: Guy Standing for allowing me the use of the PSS survey dataset; Dulcimar Albuquerque and Maria Angélica Ribeiro de Souza for newspaper data collection; Rachel Meneguello for allowing access to the polls at Centre for Studies in Public Opinion at the University of Campinas (CESOP/UNICAMP); my students at the Instituto Universitário de Pesquisas do Rio de Janeiro (IUPERJ) for heated debates on some of the problems put forward here; and Fundação Carlos Chagas Filho de Amparo à Pesquisa do Estado do Rio de Janeiro (FAPERJ) and Conselho Nacional de Desenvolvimento Científico e Tecnológico (CNPq) for funding. I share with them the eventual success of the arguments. Responsibility for the errors is mine alone. 
of unions grew some 50 per cent until 1989. The overall budget of unions amounted at that time to more than one billion \$US dollars. By the end of the decade, this money was financing the action of near 7,000 unions representing 18 million workers in more than 30,000 collective agreements. Three central federations disputed the loyalty of unions: the Central Única dos Trabalhadores (CUT), the Central Geraldos Trabalhadores (CGT), and the Confederação Geral dos Trabalhadores (CGT). Brazil experienced the most intense strike activity in Latin America, and 30 per cent of the employees in the formal labour market were affiliated to local unions. In ten years, the labour movement became one of the most important and trusted social and political forces in democratizing Brazil. ${ }^{3}$

Things changed sharply in the nineties. Challenges posed to unions and central federations as a consequence of economic restructuring based on neoliberal prescriptions have deeply impacted the labour movement's capacity for collective action and bargaining, and also its role as fosterer of strong and lasting collective identities. Unions in Brazil, I will argue, face a multidimensional crisis of representation, one of the most important expressions of which is their loss of efficacy in interest representation. I will show that structural shifts in the conditions of union action, along with unresolved institutional dilemmas of the union structure, have joined to undermine the very basis of the unionism consolidated in Brazil since 1978, dislocating the labour movement from the centre of the political arena and dramatically reducing the ability of unions to represent their constituencies' interests.

I begin in the first section with a delineation of the general conditions that favoured adversarial strategies (and hence union growth) in the 1980s, and move on to a brief description of the

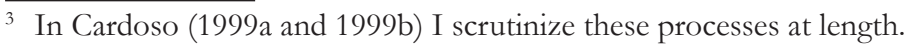


changes in the 1990s, highlighting their consequences for the pattern of unionism consolidated in the previous decade. In the second section, I scrutinize collective action and union density patterns, showing how these changes affected both the structure of the labour market and the main pillars of the unionism inherited from the eighties. In the third section, I analyse the findings of the People's Social Security Survey (PSS) conducted in Brazil in 2001. ${ }^{4}$ The survey can be understood as a timely measure of the consolidated effects of the structural changesas discussed in the first two sections-on the effectiveness of unions as interest representatives. I conclude with a general discussion of the nature of the labour movement's crisis in Brazil, connecting its various dimensions.

\section{The challenge}

The first task, then, is to explain the apparent countertendency of unionism in Brazil in the 1980s, that is to say, its enormous growth amidst global decay. This is a necessary step in the explanation of the trends of the 1990s since it will be argued that the vicissitudes of the last decade of the 20th century had much to do with the pattern of growth in the 1980s.

\section{Growth favoured}

The political and economic scenarios of the eighties were strongly favourable to unions in Brazil. First of all, and as Sader (1988) rightly argues, unions were the natural estuary for the various (more or less anonymous) forms of resistance to the civil-

\footnotetext{
4 The PSS is a huge endeavour devoted to the comparative measurement of socioeconomic and representation security in more than 15 countries around the world. It is sponsored by the ILO and coordinated by Guy Standing. For the general theoretical framework of the research programme, see Standing (1999).
} 
military regime initiated in 1964. After the first major strikes of 1978 and 1979, the regime was confronted by a significant rise in the costs of repression of the 'emerging society' (O'Donnell and Schmitter, 1986: 71), which saw in the immediately labelled 'new unionism' a pressure point that could bring about the downfall of authoritarianism. This particular context contributed to the instantaneous politicization of the new unionism. ${ }^{5}$ Another important factor was the legal, state-corporatist union structure inherited from the 1930s, a structure which was kept intact by the military. Corporatism proved to be quite flexible: it served both the authoritarian regime, as a repressive and controlling device against unions, and the emerging democracy, as the sustaining base for the rapid collective organization of union leaders countrywide (Rodrigues, 1989: 33 and passim).

At the macroeconomic level, growing inflation rates made it rational for union leaders to develop a contentious social strategy based on large, branch level strikes demanding the indexing of salaries to past inflation rates. This strategy was in opposition to restrictive official policies designed to control inflation at the cost of wage earners (Tavares de Almeida, 1992), and, as a side effect, turned strictly economic strikes into political protests against the government. The military rule was fought both at the political and the economic level, and social protest and labour unrest resumed throughout the 1980s as the main characteristic of the emerging unionism. Still, at the macroeconomic level, mean unemployment rates were very low from 1983 onwards, ranging from 2.9 per cent to 4 per cent. Nearto-full employment rates raised individual workers' bargaining power in labour markets, reducing the fear of participation and

The literature on the new unionism in Brazil abounds. An important book is Keck (1992). 
the costs of failure of collective actions (Pizzorno, 1974; Visser, 1994. On the costs of failure, Santos, 2006).

Economic stagnation and market closure restrained the impetus for productive restructuring, limiting the well-known impacts of new forms of labour organization on industrial labour markets, especially in manufacturing. ${ }^{6}$ In addition, labour relations were deeply adversarial due to authoritarian work regimes and predatory use of the labour force, expressed in despotic management, low wages (as compared to other Latin American countries), high turnover rates, and the extension of working hours through mandatory extra-time work (Humphrey, 1982; Abramo, 1999). The grassroots of manufacturing unionism, the strongest in the country and a key sector within the most important federation (the CUT) remained virtually intact.

One should not forget the state's fiscal crisis, which downgraded public servants' wages by almost 65 per cent between 1983 and 1989 (Noronha, 1992). This drop catapulted these workers into collective organization and explains the major strikes of 1987 and 1988, the longest in Brazilian history. Not surprisingly, public servants' associations and state-owned enterprises' associations were the second strongest forces inside the CUT. Last but not least, a steady economic crisis severely restricted the horizon of calculus of economic agents. Uncertain horizons tend to favour one-shot, zero-sum games in which every actor tries to get everything at once because nobody could be sure if he or she would be there in the next round (Elster, 1979; O'Donnell, 1992). Deteriorating economic conditions also favoured adversarial, all-or-nothing union strategies, a situation which proved to be quite effective in terms of the consolidation of union legitimacy and acceptance in society. In 1988, during the last round of discussions and voting on the new Federal

${ }^{6}$ The excellent Kern and Sabel (1992) is still a mandatory reference. 
Constitution, 64 per cent of adults in 10 metropolitan regions in Brazil favoured granting the right to strike to all workers, including those in the so-called 'essential services' (banking, transports, hospitals etc.) ${ }^{7}$.

These elements help to explain the enormous growth of the labour movement in Brazil in the 1980s, the strongest expression of which was the near election of a top union leader, Luis Inácio da Silva, or 'Lula', as president in 1989. Furthermore, public opinion was highly favourable toward unions throughout the decade, placing them amongst the most trusted institutions in Brazilian democracy. In 1990, 56 per cent of the voters declared that unions were trustworthy, just behind the Catholic Church (82 per cent) and the Supreme Court (62 per cent $)^{8}$. The decade saw the apex of the process of union consolidation in the emerging democracy.

These same elements also help to explain why the strongest institution of such a legitimate and consolidated labour movement was the CUT, an organization adversarial to both government and capital. Born in 1983, the CUT had almost 2,000 affiliated unions in 1989, representing 8 million workers from all economic sectors. The CUT virtually became a hegemonic institution within the unions' market of political exchange.'

\section{The mirror image}

The 1990s would completely reverse the picture of the previous decade, especially after 1994. Democratic consolidation reduced the more expressive effect of contentious discourses

\footnotetext{
7 Datafolha poll of a representative sample $(5,191)$ of voters in 10 Brazilian metropolitan areas. Data from the Centro de Estudos de Opinião Pública of the University of Campinas - CESOP/UNICAMP.

8 Instituto Brasileiro de Opinião Pública (IBOPE) poll of a representative sample $(3,650)$ of voters in Brazil. Data processed directly for this article from original database, also archived at CESOP/UNICAMP.

9 This market was conceptualized by Pizzorno (1978).
} 
and practices. The engagement of leftist parties in formal, 'bourgeois' elections supported by the labour movement greatly de-legitimized revolutionary claims, which were an integral part of the identity consolidated by the CUT. Both presidents Collor (1990 to 1992) and Cardoso (1995 to 2002) won fair elections with great popular support, in both cases against Lula, who became president only in 2002. To be politically effective again, the CUT had to change its overall strategy away from pure confrontation and de-legitimization of the political process as a whole.

On the other hand, the legal legacy of corporatism revealed its hideous face after 1988 when changes introduced by the new Federal Constitution partly freed workers to organize unions. The changes were only partial, however, as some old provisions, such as the right of unions to compulsorily tax the workers in a given 'territorial base' (the minimum size of which is the municipality), were maintained. The new conditions nevertheless stimulated the emergence of more than 500 unions per year from 1992 to 2000, further fragmenting labour representation. As a result, Brazil had by 2001, more than 10,000 workers' unions, most of which were powerless. ${ }^{10}$ That is to say, the corporatist legal structure supported rapid growth in the 1980s, and its partial debacle accelerated union fragmentation in the 1990s.

On the macroeconomic level, instead of increasing, inflation rates were reduced, from 40 per cent per month in 1994 to less than 10 per cent per year in 1996, and to below 2 per cent in 1998. In contrast, open unemployment rates exploded, from 4 per cent in 1990 to 8 per cent in 2000, while manufacturing lost almost one third (more than two million) of its formal, registered jobs in the same period due to economic restructuring through market liberalization. In addition, privatization of state-owned companies eroded the social basis of some of

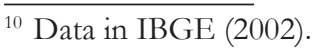


the strongest unions in the country, most of which were CUT affiliates. Moreover, the formal labour market shrank from 56 to less than 45 per cent of the economically active population between 1989 and 2000, ${ }^{11}$ reducing the structural basis upon which local unions had built their edifices.

The end of inflation, the overall support for Cardoso's economic adjustment plan, the emergence of structural job insecurity due to economic restructuring (Standing 1999, and also the third section below), and industrial restructuring with quality control mechanisms jeopardized zero-sum, all-or-nothing strategies. Instead, compromise became the rule of the game. ${ }^{12}$ In fact, firms in competitive manufacturing branches, soon followed by every other economic sectors, experienced deep industrial restructuring based on new informational technologies and forms of work organization inspired by 'lean production' recipes (CNI/SENAI, 1998; Salerno, 1998; Bonelli, 1999; Rachid, 2000; Jinkings, 2002; Antunes, 2003). The combination of the goal of 'zero defect' with just-in-time delivery across the production chains implies the transference of quality control to the workers themselves (see Jones, 1991 or Coriat, 1991 for details). The new forms of work organization are always connected to continuous improvement programs and total quality control mechanisms that tend to stabilize a core of central producers, train them, and stimulate their voluntary engagement in increases in productivity while trying hard to gain their loyalty against trade unions. In other words, quality control systems are institutional channels through which production or labour relations problems can be

\footnotetext{
${ }^{11}$ Data from monthly household employment surveys available at www.ibge.gov.br.

${ }^{12}$ I am not saying that this was actually happening through the labour process or in the labour market. I am only sustaining that those were the rules of the game. Cooperation and compromise were very much imposed on workers in exchange for job security, at the cost of greater workload and labour stress. See Stewart et al. (2001).
} 
directly negotiated between workers and management without the intermediation of unions. The objective is to avoid grievances from going past factory walls. In place of adversarial labour relations and despotic management, the 'new workplace' is characterized, at least in its ideological form, by partnership and cooperation between production agents (see Heckscher, 1996; McCabe and Black, 1997; Boltanski and Chiapello, 2002; Oliveira, 2003; Wever, 1995).

Since 1990, governments have not succeeded in resolving fiscal limitations or reforming the state apparatus in order to reverse the tendency toward public services deterioration. On the contrary, these problems have deepened. Notwithstanding these trends, the stabilization of the economy coupled with the end of inflation made it hard for public servants' unions to sustain an adversarial position with government. Malaise and apathy has been the general mood in street level bureaucracies. Depressed salaries and bad working conditions have forced many workers to accumulate other jobs, further serving to worsen the quality of services and to de-legitimize civil servants' wage claims. The major, long-lasting public servants' strikes of the eighties have not been repeated and are unlikley to take place again.

Last but not least, a word on finance. Unions in Brazil are financed by an array of sources. Part of the money comes from compulsory 'contributions' (the so called 'imposto sindical) from their rank and file, part from 'voluntary' contributions approved in workers' assemblies, and part from monthly voluntary individual contributions from associates. Only the last are purely voluntary. The contributions approved in assemblies are compulsorily charged on pay-cheques once they are collectively approved by a non-qualified majority. ${ }^{13}$ Nonetheless, all these forms of

${ }^{13}$ The law does not establish which proportion of the rank and file must be present at assemblies so as to ratify the tax. However, a worker can refuse to pay this contribution by petitioning against it to the employer. 
funding have been under stress due to growing unemployment rates, de-formalization of labour relations (only formal workers have 'formal' pay-cheques from which to make compulsory deductions), and competition from emerging unions created since the 1988 Constitution. Virtually every individual union has faced budgetary problems and gone through institutional restructuring and downsizing. The same is true at the level of central federations.

\section{Ashes and fire}

The structural changes identified above have had a strong impact on the very profile of unions and on their capacity for collective action. The aggregate data available reveals a small but steady decay in union density during the 1990s. As Table 1 indicates, union density decreased from 22 per cent in 1988 to 19 per cent in 2001. One would expect stronger losses, given the hostile environment outlined above. But what Table 1 does not reveal is that there has been an astonishing migration of union affiliates from finance and manufacturing to the services and commercial sectors, basically accounted for by the absolute variation in employment in the economy as a whole.

Table 1. Evolution of union density rates of the Salaried Occupied Population (SOP) above the age of 18, and of Registered Salaried Workers (RSW) above the age of 18, 1988-2001.

\begin{tabular}{|l|c|c|c|c|c|c|c|c|c|}
\hline Indicators & $\mathbf{1 9 8 8}$ & $\mathbf{1 9 9 2}$ & $\mathbf{1 9 9 3}$ & $\mathbf{1 9 9 5}$ & $\mathbf{1 9 9 6}$ & $\mathbf{1 9 9 7}$ & $\mathbf{1 9 9 8}$ & $\mathbf{1 9 9 9}$ & $\mathbf{2 0 0 1}$ \\
\hline SOP ('000) & 34,279 & 34,778 & 35,696 & 37,061 & 37,739 & 38,261 & 38,588 & 39,529 & 44,085 \\
\hline $\begin{array}{l}\text { Affiliated } \\
\text { to a union } \\
\text { ('000) }\end{array}$ & 7,521 & 7,837 & 7,932 & 8,020 & 7,935 & 7,931 & 7,752 & 7,798 & 8,496 \\
\hline Density (\%) & 21.94 & 22.53 & 22.22 & 21.64 & 21.03 & 20.73 & 20.09 & 20.09 & 19.27 \\
\hline
\end{tabular}

Source: National Household Survey, PNAD/IBGE, 1988 to 2001. Built from original data sets. 
A closer examination of data for the period shows that the substantial decline? of employment in finance and manufacturing and the reduction in absolute density that followed were clearly a direct consequence of the neoliberal policies undertaken. While it is true that the manufacturing sector had been losing jobs since the beginning of the decade, after 1996 there was a clear intensification in the reduction of union density rates in this particular branch. For instance, in 1992 there were 45,000 fewer affiliates than four years earlier. In 1995, the difference was almost the same: 47,000 fewer affiliates. But in 1996, the second year of the economic adjustment plan, unions in manufacturing lost 211,000 affiliates, a figure that rose to 414,000 in 1998 when compared to 1988. This amounts to a loss of one-fifth of the total number that affiliates reported in 1988 (see Cardoso, 2003).

These important figures notwithstanding, manufacturing alone lost 2.2 million of the 8 million formal registered jobs that existed in 1988. As already mentioned, registered workers are the traditional and legal clienteles of local unions, those from whom these organizations can compulsorily charge union taxes and contributions. An important part of the crisis of unionism in the manufacturing sector is due, then, both to the reduction of absolute employment and to the loss of the quality of the remaining jobs, which are becoming increasingly informal. In the financial sector the trend is similar, with the loss of 50 per cent of the formal jobs existent in 1988. In other words, industrial restructuring has strongly hit both manufacturing and finance unionism, the most important pillars of the CUT.

It is true that strike activity has never left the scene, but it has been far less intense from 1992 onwards. Graph 1 shows the evolution of the number of strikes and the mean number of strikers per strike between 1980 and 1999. The number of strikes escalated from 1982 to 1989, decreasing to a more stable level in the 1990s, and varying between 500 and 1,500 per 
year. The number of participants in strikes followed a similar pattern. Brazil may since have faced some kind of stabilization of collective action at a level which, it should be noted, was still higher than in many western and most Latin American countries ${ }^{14}$.

Graph 1. Strikes and strikers in 20 years

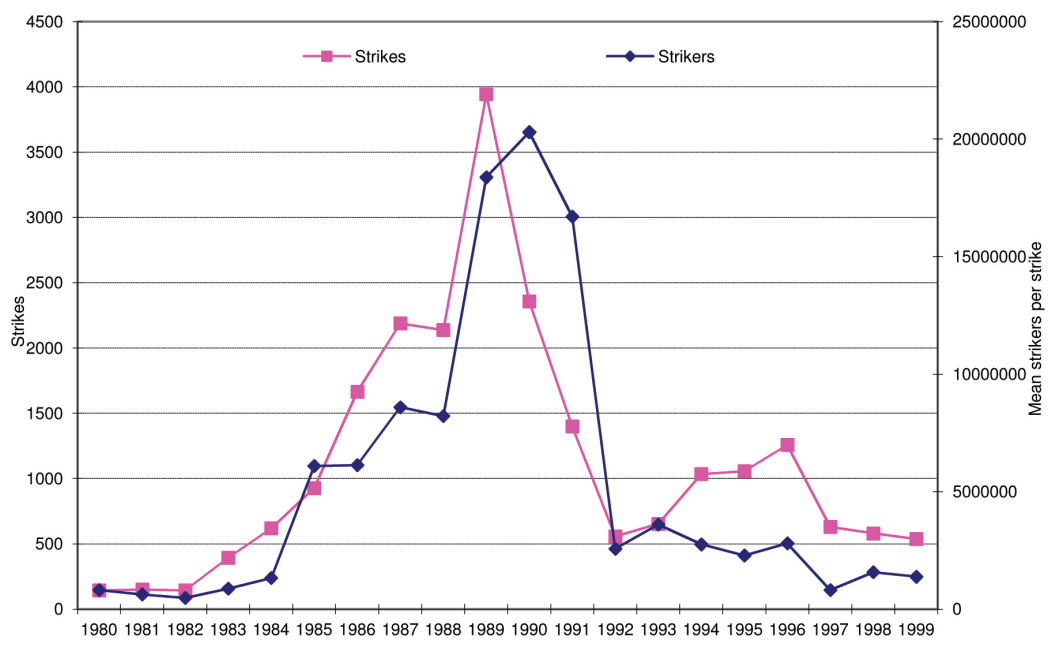

Source: Noronha (1994); and Departamento Intersindical de Estatísticas e Estudos Socioeconômicos - DIEESE.

In any event, the acute decline in the number of strikes from the levels of the 1980s may also reflect the increase in workers' fear of engaging in collective action. High unemployment rates, wage insecurity, job insecurity and increasing informality of the labour market as a whole and employment insecurity in growing sections of the labour force, ${ }^{15}$ are augmenting the costs of failure

${ }^{14}$ Peru, Bolivia, Chile, Ecuador, México, Guatemala, the United States and Canada had lower strike rates than Brazil in the 1990s. Data is available at laborsta.ilo.org.

15 Again, for the design of the idea of socioeconomic security, see Standing (1999). 
of collective action (Santos, 2006). The loss of one's job as a punishment for union militancy may represent impoverishment, social exclusion, and hunger. Workers are not willing to act collectively, and without collective action, unions are weak.

\section{The People's Social Security Survey}

One of the major consequences of the structural and institutional changes deriving from market-oriented policies has been the loss of union efficiency and efficacy in the representation of workers' interests. In exchange for some job security (restricted to a short period of time or to a small number of workers), strong unions, such as the Metal Workers' Union of the São Paulo ABC Region, had to renounce to fringe benefits and other important gains - such as transport, housing and food subsidies, and overtime paid above legal provisions obtained with great difficulty in the 1980s (Cardoso, 2003: chap. 1; also Araújo and Gitahy, 2003: 105-6). Such practices have not been isolated events. As can be seen in DIEESE (1997) and Oliveira (2003), collective bargaining in the nineties has resulted in major losses of contractual rights established in the eighties, even within the strongest unions in the country. Unions have apparently lost most of their capacity to assure workers' rights.

Within this context, it is not difficult to assess the relevance of the PSS survey since it covers many dimensions of people's socioeconomic insecurity and their affiliation to unions. Conducted in Brazil in 2001, the survey can be understood as a timely appraisal of the overall consequences of the neoliberal policies implemented in the 1990s and their impact on workers' perception of, and relation to, unions. For this reason, the survey is a strategic tool for investigating the assertion that unions have lost representational capacity. The survey offer possibilities for addressing the following questions: Does belonging to unions 
make a difference? Does it assure workers different and better labour market positions, salaries, access to welfare provisions, and judgment of current and/or future life standards? In sum, are unions effective protectors of workers' rights? If the previous reasoning is correct, one would expect negative answers to most of these questions. This is what will be scrutinized in the next section. ${ }^{16}$

Job security

Perhaps the most important dimension of socioeconomic security affecting workers' willingness to participate in union activities is job security, a worker's perception that his or her job is not at risk, no matter what. Workers' related attitudes concerning present conditions and future prospects of their jobs are also important. Table 2 shows that if a worker is a union member, he or she will most certainly have a permanent contract (94\%) and will have never faced an unemployment spell (86\%). Nonmembers' probabilities are of $67 \%$ in both cases, a fact that clearly indicates a key difference in favour of union members. However, as I will argue below, the difference reflects the formal character of union jobs. Almost 98\% of union members have registered (private or public) contracts, as opposed to $66 \%$ of non-union members. Registered jobs, it should be noted, are bound to be contractually permanent. Only very recently (1998) has the Brazilian labour law instituted the possibility of temporary work contracts. Because in most cases this option is subject to union approval, temporary work has remained

16 The focus of the analysis will be the total occupied salaried workforce interviewed in the three metropolitan areas covered by the PSS: Rio de Janeiro, São Paulo and Recife. This decision equates the PSS data to the ILO's standards concerning 'adjusted' union density in international comparison (see ILO, 1997). 
marginal within the country's labour market. Employers prefer to have unregistered workers instead, as we will see.

Table 2. Impact of union affiliation on measures of job security $(\%)$

\begin{tabular}{|c|c|c|c|}
\hline $\begin{array}{l}\text { Measures of job } \\
\text { security }\end{array}$ & Categories & Non-Union & Unionized \\
\hline Has a permanent contract & Yes & 66.84 & 93.87 \\
\hline $\begin{array}{l}\text { Has been unemployed } \\
\text { before }\end{array}$ & No & 66.6 & 86.31 \\
\hline $\begin{array}{l}\text { Has only the principal } \\
\text { occupation }\end{array}$ & Yes & 92.29 & 90.91 \\
\hline \multirow{3}{*}{ Occupation status } & Registered employee & 56.15 & 74.43 \\
\hline & Unregistered employee & 33.88 & 2.33 \\
\hline & Public servant & 9.97 & 23.24 \\
\hline \multicolumn{4}{|l|}{$\begin{array}{l}\text { Attitudes concerning job } \\
\text { security }\end{array}$} \\
\hline $\begin{array}{l}\text { Sure to secure job in next } \\
12 \text { months }\end{array}$ & Yes & 56.47 & 62.38 \\
\hline $\begin{array}{l}\text { Likely to be promoted in } \\
2 \text { years }\end{array}$ & Yes & 30.64 & 37.99 \\
\hline \multirow{4}{*}{$\begin{array}{l}\text { Hard to find same or } \\
\text { better job elsewhere }\end{array}$} & Not hard & 36.78 & 30.69 \\
\hline & A bit hard & 13.72 & 12.65 \\
\hline & Hard & 12.08 & 14.61 \\
\hline & Very hard & 37.42 & 42.04 \\
\hline \multirow{6}{*}{$\begin{array}{l}\text { Salary compared to } 2 \\
\text { years ago }\end{array}$} & Higher & 32.42 & 33.19 \\
\hline & The same & 40.34 & 37.55 \\
\hline & Lower & 22.11 & 28.23 \\
\hline & Don't know & 1.24 & 0.13 \\
\hline & Not applicable & 2.26 & 0.6 \\
\hline & $\mathrm{N} / \mathrm{A}$ & 1.63 & 0.3 \\
\hline \multirow{8}{*}{ Index of job satisfaction } & No satisfaction & 9.34 & 5.06 \\
\hline & 1 & 9.66 & 9.09 \\
\hline & 2 & 12.02 & 11.38 \\
\hline & 3 & 16.18 & 15.95 \\
\hline & 4 & 16.76 & 15.35 \\
\hline & 5 & 14.41 & 15.18 \\
\hline & 6 & 11.82 & 10.99 \\
\hline & Total satisfaction & 9.8 & 17.01 \\
\hline \multicolumn{2}{|l|}{$\mathrm{N}=$} & 1,028 & 376 \\
\hline
\end{tabular}

Source: PSS Survey, Brazil 
Being unionized, as opposed to not being unionized, is, therefore, a strong and statistically significant indication of formally permanent labour contracts. But to say that union jobs are more secure than non-union jobs is different from saying that unions cause job security. For the moment, I am just stating that these dimensions are closely correlated. I will return to this point below. It is worth mentioning also that to have a permanent contract in Brazil does not necessarily mean that the job is secure. It only means that the worker can only be fired for a reason of 'just cause' (for example, absenteeism, alcoholism, indiscipline). Otherwise, companies will have to pay a fine amounting to $40 \%$ of the Guaranty Fund for Employment Duration (FGTS), a fund made of contributions from firms amounting to $8 \%$ of the monthly salaries, and administered by representatives of employers, employees and government. The worker is entitled to the fund and the fine when dismissed for a reason other than 'just cause'. This is what I mean by the fact that contracts are only formally permanent. The only barrier to dismissal is monetary, and it is very low in international comparison, as shown in Cardoso and Lage (2007).

Table 2 also shows, under the heading 'attitudes concerning job security', that unionized workers are just a bit more certain about the prospects of keeping their job in the next 12 months, but both they and their non-union peers are fairly optimistic about this matter. This optimism contrasts to the (also) undifferentiated pessimism in other important issues. Union affiliates are only slightly more positive about the chances of promotion in the next two years $(38 \%$, as opposed to $31 \%$ among non-union members), although pessimism is the main feeling in both strata. As regards job satisfaction, ${ }^{17}$ the differences in the distribution of

${ }^{17}$ The variable is an index that sums up total or flat satisfaction with: 1. Salary; 2. Subsidiary benefits; 3. Kind or work done; 4. Degree of autonomy; 5. 
the reported index are not statistically significant. The same holds for the perceived difficulty related to the prospects of finding an equivalent job (considered a difficult endeavour by all strata), and for the perception of the evolution of the real salaries in the last two years. Here, most workers perceive salaries as stationary or higher today (summing up to $70 \%$ in both categories).

In sum, union affiliation is an important variable in predicting job security. However, it does not help to distinguish attitudes concerning job satisfaction. Union affiliation also has little, if anything, to say about the union and non-union members' perceptions about job security and rewards. Apparently, union workers are safer because they work in the formal, regulated sector, and are therefore subject to formal standards of working conditions and contracts, and not because joining unions results in job security. If this reasoning is plausible, unionization would be merely an indication of an underlying factor, namely working in the formal sector of the economy. This hypothesis can be rigorously tested by the available data.

\section{Access to labour rights and welfare}

Another central dimension of socio-economic security is the possibility of sustained access to legal and/or contractual benefits at work. In Brazil, the two regulatory codes, the Constitution and the CLT, leave little space for unions as chief mechanisms in labour market regulation, the usual exceptions notwithstanding. ${ }^{18}$ Noronha (2000) shows that most collective contracts only instantiate the legal provisions, reducing the possible local level constitutional role of capital and

Opportunity for improving skills; 6. Opportunity for promotion; 7. Work environment. Crombach's Alpha is .88.

${ }^{18}$ Which include petroleum workers and some proportion of metal, bank, education and chemical workers. 
labour representatives. Surveying the literature on collective bargaining in Brazil in the nineties, Oliveira (2003) draws similar conclusions.

One of the main consequences of this model is the necessary judicialization of class relations when labour rights are contested or denied by employers. This is clearly happening in Brazil. Graph 2 shows the evolution of judicial demands in the first layer of the labour judicial system in the last 60 years. From 1941 to 1961 the mean annual growth was of 14,000 cases. From 1962 to 1987 (with the exception of the 1971-73 period) the mean growth was of 34,000 cases per year. But from 1988 to 1997 the mean growth was of more than 112,000 cases per year. In 1997 alone, labour courts in Brazil received almost 2 million petitions. After the 1988 Constitution, which greatly extended workers' constitutional rights, the employers seem to be contesting more intensely than ever the system of labour regulations. In a legislation-led model, the unsurprising consequence of such contestation is incremental growth in judicial demands. ${ }^{19}$

${ }^{19}$ I cannot develop this argument here. But it is largely discussed in Cardoso 2003, chapter 3. 
Graph 2. Judicial demands in the first level of labour courts in Brazil, 1941-2000

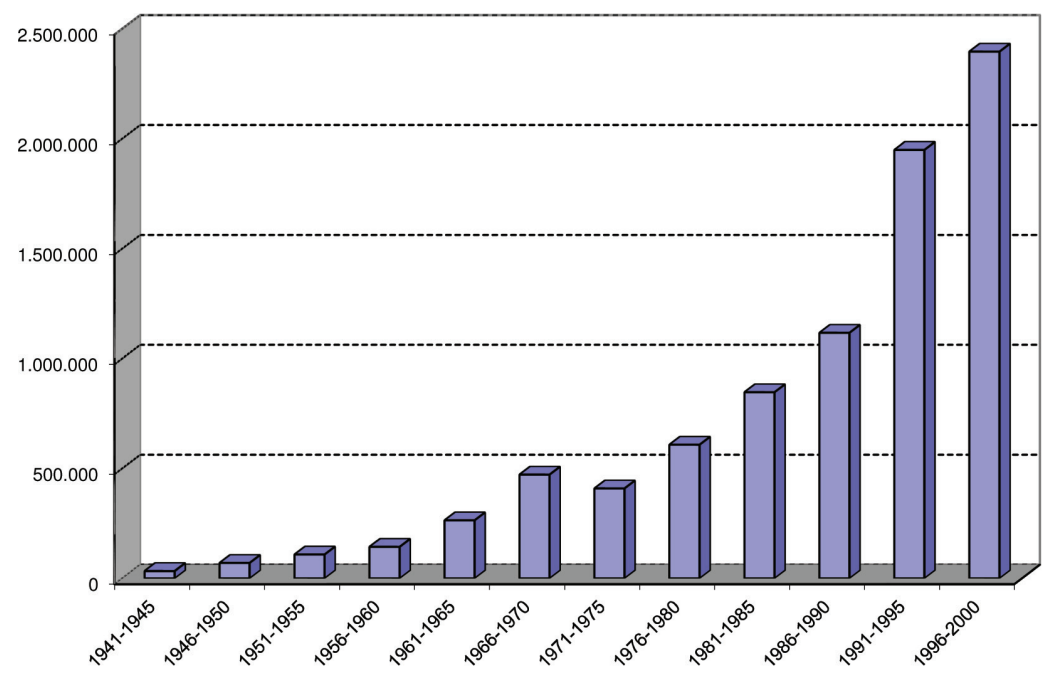

Source: Supreme Labour Court

The high volume of court cases also means that, although labour rights are quite strict and encompassing, their recognition by employers is not guaranteed a priori. This reality, as argued in this book, is the very nature of the democratic class struggle in Brazil. Although in Spain, Argentina, Portugal and other countries, employers and their representatives did manage to change the law, leading to increasing flexibility in labour market regulation, in Brazil flexibilization is a 'cold blooded' process: many employers simply decide to not recognize labour law as a legitimate mediator in labour relations. The consequence is the increase in the rate of illegality of market salaried relations. In 1989 the proportion of registered salaried workers in the occupied labour force was 56 per cent. In 2000 the figure had dropped to less than 45 per cent, as already noted. Self-employment and non-registered jobs account for those 11 percentage points lost by the formal sector. 
Table 2 has shown that union membership is almost exclusively distributed among registered workers and public servants. Because the industrial relations model is underpinned by legislation, most of the benefits listed in the questionnaire of the PSS survey are statutorily guaranteed to registered workers. ${ }^{20}$ Thus, we should expect union workers to have a consistently higher rate of access to those legal and contractual benefits than their non-union peers simply because of the nature of the model, which grants formal employees legal rights. By the same token, because employers are increasingly de-legitimating the current labour law, we should also expect that even among unionized, salaried workers some of those benefits no longer hold.

Both expectations are strongly confirmed by the available data. Table 3 shows the distribution of an index of access to legal and contractual benefits built out of 12 of the 14 alternatives in the PSS questionnaire (see note 20), broken down by union membership. Among union members, 50\% have access to 10 benefits or more, while among non-union, salaried workers the median value is seven. The proportion of union affiliates with this level of access is only $23 \%$. So, union affiliation is indeed a strong indication of access to legal and contractual benefits. At the same time, if we take only those benefits guaranteed by law into consideration, ${ }^{21}$ as few as $42 \%$ of union members

\footnotetext{
20 The specific question was: 'In your main occupation are you entitled to the following benefits?' And the alternatives were: a) Paid sick leave; b) Paid maternity leave; c) Severance payment; d) Paid holidays; e) Christmas bonus; f) Retirement; g) Unemployment insurance; h) Scholarship or paid childcare; i) Health plan; j) Family allowance; k) Food stamps program/meal; 1) Transportation program; m) Bonus; n) Other. In the construction of the index of access discussed, I discarded the alternatives 'Bonus,' exclusive to employers, and 'Other,' because of its indeterminacy. The index is very robust and has a Crombach Alpha of .9048 .

${ }^{21}$ These are the benefits a) to g), and j) in question C33 described in the previous footnote. All the others are also legal benefits, but they are not universally granted, depending upon firm size.
} 
have access to all eight of them. Only 67\% have access to at least seven legal rights, which by no means represents universal access. Even though guaranteed by law, many registered or public union-affiliated workers still feel that they are not entitled to some of those benefits. This is an indication that employers are indeed riding roughshod over the legal system of labour market regulation, both for unionized and for non-unionized workers, and that union membership is no guarantee that the law will be perceived as valid in day-to-day labour relations ${ }^{22}$.

Table 3. Index of access to legal and contractual benefits and union affiliation

\begin{tabular}{|c|c|c|}
\hline Index of access to rights & Non-union (\%) & Unionized (\%) \\
\hline No access & 13.92 & 0.7 \\
\hline 1 & 5.4 & 0.6 \\
\hline 2 & 4.12 & 0.0 \\
\hline 3 & 4.1 & 0.73 \\
\hline 4 & 3.45 & 1.73 \\
\hline 5 & 4.82 & 1.76 \\
\hline 6 & 6.36 & 6.49 \\
\hline 7 & 8.58 & 10.89 \\
\hline 8 & 12.6 & 11.32 \\
\hline 9 & 11.45 & 14.51 \\
\hline 10 & 10.14 & 17.61 \\
\hline 11 & 8.26 & 17.51 \\
\hline Access to all & 6.8 & 16.15 \\
\hline N= & 1,014 & 386 \\
\hline
\end{tabular}

Source: PSS Survey

${ }^{22}$ And there is always the possibility that some workers simply don't know their legal rights. 
Pushing the argument somewhat further, I have suggested in the previous section that it may be the case that union affiliation indicates rights security just or mostly because unions enrol workers in the formal labour market, a fact that in itself entitles them to legal benefits. Here, as before, unionization and access to benefits would be nothing but indicators of belonging or not to the formal labour market. In order to test for this hypothesis, I have regressed some selected, theoretically relevant covariates on the index of access to rights. The results are shown in Table 4. Significant covariates are in italic.

Table 4. Multivariate linear regression (OLS) on the index of access to legal and contractual benefits

\begin{tabular}{|l|c|c|c|c|}
\hline Covariates & Standardized B & T & Sig. of t & VIF \\
\hline (Constant) & & 1.409 & 0.159 & \\
\hline School grade & 0.066 & 2.836 & 0.005 & 1.646 \\
\hline Log of hourly income & 0.028 & 1.142 & 0.254 & 1.903 \\
\hline São Paulo & -0.002 & -0.129 & 0.898 & 1.113 \\
\hline $\begin{array}{l}\text { Has been unemployed } \\
\text { before? }\end{array}$ & 0.02 & 1.01 & 0.313 & 1.24 \\
\hline Manufacturing & -0.011 & -0.581 & 0.562 & 1.155 \\
\hline Registered salaried worker & 0.333 & 14.629 & 0.000 & 1.598 \\
\hline Union member & 0.066 & 3.333 & 0.001 & 1.208 \\
\hline Size of firm & 0.246 & 11.403 & 0.000 & 1.436 \\
\hline Age & 0 & 0.007 & 0.994 & 1.595 \\
\hline Gender (male) & -0.019 & -0.989 & 0.323 & 1.162 \\
\hline Race (white) & -0.02 & -1.09 & 0.276 & 1.086 \\
\hline Has a permanent contract & 0.354 & 15.018 & 0.000 & 1.708 \\
\hline $\begin{array}{l}\text { Time of employment in } \\
\text { months }\end{array}$ & 0.052 & 2.206 & 0.028 & 1.724 \\
\hline
\end{tabular}

\section{Model statistics:}

Adjusted R square: 0.60

Df: 12

Durbin-Watson: 2.008

Model F: 154.186

Sig: 0.000

Obs.: These robust statistics show that the estimates are BLUE.

Source: PSS survey 
As expected, given the hypothesis scrutinized here, having a permanent contract has the most intense and consistent impact on the index of access to legal and contractual rights (compare standardized $\mathrm{B}$ values and $\mathrm{t}$ statistics). Although the table does not show it, this covariate alone increases the mean access by 3.1 points. Being a registered employee, the second major impact, increases the mean rate of access by 2.44 points. The size of firm is also very important. The fourth important, significant covariate is, precisely, union affiliation, followed by school grade and time of employment (tenure) in months. All six estimates are significant at least at the 0.02 level. The other variables are not significant whatsoever: income, living in São Paulo as opposed to living in Rio de Janeiro or Recife, being previously unemployed, age, gender, or race, have no importance for the index's variance.

To say this differently, even when controlling for formal sector indicators such as firm size, having a permanent contract, and being a registered worker, union affiliation still has a statistically significant, though very small, intervening power. Belonging to unions increases the mean access to benefits by only 0.54 points, controlling for the other measures. The parameter is significant at the .001 level. I will return to this point in the concluding remarks.

As regards welfare, the main dimensions covered by the PSS questionnaire refer to the perceived prospects for the quality of life after the age of 60 , and for the chances of proper retirement. Table 5 shows little influence of union membership on workers' attitudes. Union and non-union members are equally pessimistic with respect to access to health services in the future, but this pessimism is probably a consequence of equal, and quite realistic, diagnosis of future prospects for the national health system, which has experienced continuous deterioration for the last 20 years or so. Union members are a bit more pessimistic about the chances of access to a good standard of living, but a significantly higher proportion feel more confident that they will 
retire properly (45 per cent as opposed to 32 per cent of nonunion members). Retirement and the related public pension are part of workers' constitutional rights, and it is more likely for formal employees to have access to them than is the case for unregistered salaried workers.

Table 5. Prospects for life at the age of 60 and union affiliation (proportion who responded yes)

\begin{tabular}{|l|c|c|c|c|c|}
\cline { 2 - 6 } \multicolumn{1}{c|}{} & $\begin{array}{c}\text { Will have } \\
\text { access } \\
\text { to health } \\
\text { services }\end{array}$ & $\begin{array}{c}\text { Will have } \\
\text { access to } \\
\text { rents }\end{array}$ & $\begin{array}{c}\text { Will have } \\
\text { access to } \\
\text { standard of } \\
\text { living }\end{array}$ & $\begin{array}{c}\text { Considers } \\
\text { high the } \\
\text { chances } \\
\text { of retiring } \\
\text { properly }\end{array}$ & $\mathrm{N}=$ \\
\hline $\begin{array}{l}\text { Not } \\
\text { Unionized }\end{array}$ & 22.65 & 27.31 & 38.52 & 31.89 & 1.028 \\
\hline Unionized & 19.87 & 23.67 & 31.89 & 44.84 & 376 \\
\hline
\end{tabular}

Once again, belonging or not belonging to the formal sector probably explains a substantial part of the differences between union and non-union members. What is worth observing, though, is that affiliation is an indication of a more optimistic judgment about the future in only one out of four dimensions, and that salaried workers as a whole are predominantly pessimistic about their future prospects.

\section{Representation security}

Institutions can provisionally be defined as sets of stable social relations, in which mutual expectations and practices of social and political actors are based on a common body of more or less formalized rules. ${ }^{23}$ One of the main features of institutions is the consequent stabilization of members' and outsiders' expectations

\footnotetext{
${ }^{23}$ A somewhat equivalent definition can be found in Douglas, 1986.
} 
about mutual actions due to, among other things, more or less routine procedures, more or less established hierarchies of command and control, and more or less intense institutional sanctions and rewards. Representative institutions, such as unions (and also political parties), centralize the process of interest formation, foster collective identities based on the differentiation of interests from other actors, and (unlike political parties) fuel collective action as their main source of power (see, for example, Pizzorno, 1978). Among many other important features, unions help to extend members' horizon of calculus concerning material and symbolic gains in such a way that trust in the possibility of sustained institutional efficacy and efficiency is an integral part of the process of political identification and of the sentiment of 'being represented'.

The main consequence of this kind of reasoning is that workers do not have to have an active role in union life in order to feel themselves represented. The will of union members to participate is a measure of unions' social power, not of unions' legitimacy among workers. In other words, workers can identify themselves with union practices and ideologies without taking part in the process of ideology formation or in collective action. This kind of 'representation by identification' is very important in Brazil because workers do not have to formally join unions to be represented in collective bargaining or elsewhere. An existent union represents formal employees by profession in a given municipality, even against their will.

As a consequence, we would expect union membership to have a positive impact on workers' attitudes concerning union representativeness and trustworthiness. If joining unions has nothing to do with being formally represented by them, then union affiliation can be hypothesized as a measure of the degree of a worker's adhesion to institutional goals and, possibly, ideologies. In Brazil, of course, workers join unions also to have access to social, health, and legal services. But I am hypothesizing here that, 
even in this particular case, frequency of access to the union's headquarters, contacts with union leaders, and participation in union life, are all factors capable of shaping attitudes and, perhaps, practices. ${ }^{24}$ The PSS survey gives some indications in that direction.

First of all, union members think that unions adequately and efficiently represent workers' interests in a slightly higher proportion than do non-members. The figures are $54 \%$ and $48 \%$ respectively. But, and this is very interesting, this perception is countervailed by the fact that the majority of both members and non-members do not see unions as trustworthy, even though unionized workers are a bit more generous: the proportions for those saying unions are not trustworthy institutions are 59\% for union and 69\% for non-union members. The proportions for those saying they are trustworthy are $37 \%$ and $27 \%$ respectively. Unions are perceived to be efficient, but certainly not trustworthy. Why?

Trust in political and representation institutions has to do with many intertwined dimensions that are very difficult to isolate in survey research. At a more empirical level, one may trust unions for their efficiency, but see union leaders as egoistically oriented, or vice-versa. Ideologically oriented leaders may be perceived as untrustworthy because of some apparent incompatibility of purposes and/or methods, despite their effectiveness. At a more general, abstract level, trustworthiness is an integral part of the identification and legitimating processes that give the political system some reliability and stability over time. ${ }^{25}$ At this level, trust is a matter of identification with the democratic institutional network as a system of political referents, serving as a structured base for action and, also, for the construction of social and political values. I believe that it is here that the explanation lies for

\footnotetext{
${ }^{24}$ This hypothesis cannot be tested by the data scrutinized here. But see Cardoso (1999b: chap 3) for a long discussion on the matter based on survey research.

25 See Seligman (2000), among a growing literature, most of which in one way or another departs from Luhmann (1996).
} 
the apparent paradox of the coexistence of sentiments that unions are at the same time efficient but untrustworthy.

Implicit in this kind of attitude toward unions is a harsh and sweeping judgment of political, democratic institutions as a whole. This judgment is contaminating unions despite the majority's perception that they represent workers' interests. Table 6 evidences this phenomenon. Political parties, parliament, and the judicial system are all summarily judged, although union members tend to find them trustworthy in a slightly larger proportion than do nonunion members. The press, the so-called 'fourth power,' does not escape the negative assessment. On the contrary, civil society and religious associations - with the exception of NGOs - are in a much better position and union members are again more willing to find them trustworthy than are non-members. Unions, and possibly NGOs, are both perceived as part of the political system, and it is the political institutions as such that are being de-legitimized.

Table 6. Proportion of union and non-union members saying that political and social institutions are trustworthy

\begin{tabular}{|l|c|c|}
\hline Social and Political Institutions & \multicolumn{2}{|c|}{ Proportion saying trustworthy } \\
\hline & Not Unionized & Unionized \\
\hline Political parties & 7.21 & 9.52 \\
\hline Unions & 27.13 & 37.12 \\
\hline Neighbourhood associations & 37.71 & 45.17 \\
\hline Church or religious institutions & 59.3 & 60.49 \\
\hline NGOs & 24.9 & 32.72 \\
\hline Parents' associations & 51.26 & 58.16 \\
\hline Students' association & 45.61 & 54.59 \\
\hline Parliament & 17.58 & 20.77 \\
\hline The press & 29.45 & 34.89 \\
\hline Justice & 26.57 & 25.6 \\
\hline Police & 18.99 & 20.67 \\
\hline Other & 4.68 & 7.12 \\
\hline
\end{tabular}

Source: PSS Survey 
Not trusting political parties, parliament, justice, and the press clearly means that union and non-union members do not feel themselves represented by the political system. They perceive that their voice has been obliterated. Civil society associations and institutions, on the other hand, with the possible exception of religious associations, are not strong substitutes for the lack of confidence in politics. Representation insecurity, in sum, is the main feature of the respondents' attitudes, and again, union members are only slightly better off.

The negativejudgement of the political and representational systems has an important complement in the strong, generalized absence from participation in social and political organizations, as demonstrated in Table 7. Union members participate more than others, but the difference is only 9 percentage points $(29 \%$ to $20 \%$ respectively). In other words, $29 \%$ of union affiliates report participation in other social or political institutions, most of them religious associations. These other institutions are also the preferred loci of non-union members, but at a lower rate of participation. Participation in political and organizational life, then, is the exception among workers as a whole in Brazil. Their lack of involvement means that the feeling of being misrepresented by the political system is only partly compensated for by routinized social bonds, i.e., those institutions that in one way or another deal with everyday concerns and necessities. Voice representation is weak both at the general, political level, and at the local, social level. 
Table 7. Participation in social and political institutions and union membership

\begin{tabular}{|l|l|l|}
\hline Measures of Participation & Non-union & Union \\
\hline Political parties & 1.78 & 2.8 \\
\hline Religious associations & 10.42 & 14.78 \\
\hline Ecological associations & 0.55 & 2.23 \\
\hline Neighbourhood associations & 2.91 & 5.46 \\
\hline Parents' associations & 2.4 & 3.83 \\
\hline Students' associations & 2.99 & 2.5 \\
\hline Philanthropic associations & 1.67 & 3.86 \\
\hline NGOs & 0.54 & 1.9 \\
\hline Other & 1.75 & 7.92 \\
\hline None & 80.26 & 71.11 \\
\hline N $=$ & 1,028 & 376 \\
\hline
\end{tabular}

Source: PSS Survey, Brazil

In sum, union membership does not consistently determine voice representation, either by attitudes concerning the political system, or by practices concerning civic participation. Union members are only slightly more secure than non-members, but political malaise seems to be the concept that better encapsulates the general picture. I will now try and derive some consequences from the analysis.

\section{Conclusion}

I have tried to show that the turbulent environment of the 1990s put unionism at a crossroads in Brazil. Currently, the challenges are of a new character as compared to other critical junctures in the past. The neoliberal decade brought labour market insecurity to a vast majority of the Brazilian population. Most of all, neoliberal public policies did not appropriately take into account the very nature of the instruments that 
have historically helped to galvanize social cohesion, the main elements of which I've been trying to disentangle in this book.

Work is still a central element of the biographies of the vast majority of the population. What the neoliberal era has actually done has been to deny this simple, socioeconomic truth. Deregulating labour relations has meant breaking the inclusionary promise of the formal capitalist economy and the formal labour market thus wiping away from the workers' horizon the prospect of a decent job for a decent life. The changing reality of the world of work helps to explain why there was a decrease in workers' unrest. Workers, afraid of losing their formal jobs, and of losing the rights of the vanishing Promised Land, acquiesced to draconian labour relations, thus reducing their impetus for collective action.

Brazilians have also witnessed a broader process of depoliticization of the economy. The state withdrew from aspects of the social life once perceived as part of its responsibility. Economic development as a raison d'état, characteristic of imports' substitution models, resulted in a conceptualization of economic relations as intrinsically politicized in a number of different ways. First of all, the accumulation of capital in the private sector was a direct consequence of its access to public resources which, because scarce, could not be universally distributed (Oliveira, 1988). As a consequence, the survival of large, nationally based capitalist investments have heavily depended on the bourgeoisie's capacity of manoeuvre among numerous small, technocratic, and relatively clientelistic schemes to access those resources (Sallum Jr., 1996). It should be noted that these symbiotic relations between the national-bourgeoisie and the state-bureaucratic circles were very astutely named 'bureaucratic rings' by former president Fernando Henrique Cardoso in which public and private interests were intertwined.

Second, the entrepreneurial state fulfilled the task of providing infrastructural conditions to the movement of private 
capitals, both in the finance system and in the rural and urban productive sectors. Major investments in communications and transportation services, in heavy industry, and in energy production and distribution are some important examples. But we must not forget the role of state banks (federal and local, equally) in the financing of private investments with subsidized interest rates. Moreover, the federal government's socialization of all private debts in the mid-1970s was one of the main factors behind the growth of the public external debt (Appy, 1989). Development as a state's reason entangled 'public interest' with 'capitalist accumulation'.

Third, apart from externalities in the strict economic sense, the role of the state in the regulation of class relations has acquired considerable scope in Brazilian modern history. Getúlio Vargas's corporatism is its most salient expression, as I've been trying to show here. Vargas's corporatism not only established the parameters for capital and labour relations, making them a part of the state itself; it also meant that the constitution of the labour market was strictly delimited by the CLT, the labour code discussed above. To say it properly, the CLT de-commodified the labour force (in the sense of Offe, 1984), and judicialized class relations (in the sense of Habermas, 1987).

The reversion of this pattern of capital-labour relations by neoliberal policies brought back the commodification of the labour force, not exactly by means of the flexibilization of the existing code, but by the extension of illegal contracts to areas once secured from informal labour relations, such as manufacturing and modern services. The current re-commodification of labour relations also means that the state is no longer the intermediary in the conflict of interests between capital and labour. It is, in fact, an intermediary of growing importance in the conflict over individual rights, and the labour courts are busier than ever in response to workers' increasing awareness that employers are 
flexibilizing the labour market in 'cold blood.' But judicialization of labour relations is different from their politicization. Labour demands tend to be individual, not collective. They do not require association or collusion. They do not feed collective action or collective identities. They still take the state as the guardian of rights, but just as they see it as a guardian of citizenship or civil rights. Instead of collectivities represented by unions in statecorporatist arrangements, we have individuals represented by lawyers in judicial courts.

In sum, until very recently, state and economic development existed in causal connection, the latter being the result of the conscious reasoning and action of the former. Market failures were state failures. In the new, neoliberal environment, market forces have driven state politics. The terms have been reversed. The extrication of the state from the regulation of the economy, and the liberation of market forces in a state-dependent society, has resulted in an increased perception of socioeconomic insecurity. In a survey conducted in 1986 in a random, representative sample of the population of the city of São Paulo, $52.5 \%$ of the respondents said that they were not worried about losing their jobs. ${ }^{26}$ Among union members, the percentage was as high as $82.5 \%$. In contrast, in 2001, the PSS survey for the Metropolitan Region of São Paulo identified $31 \%$ and $44.5 \%$ of respondents, respectively, as saying that they were secure about their employment. The wording of the questions was not the same in the two surveys, but the results nonetheless were remarkably different. Job security became one main issue for workers as a whole. ${ }^{27}$

\footnotetext{
${ }^{26}$ Poll of the Instituto de Estudos e Pesquisas de São Paulo - IDESP on a representative sample of the population of the city of São Paulo (2,561 individuals). I thank CESOP/UNICAMP for allowing me access to the database.

${ }^{27}$ In February 1999, a poll on a random sample of the Brazilian population found that $35 \%$ of the respondents said that stimulus to employment creation
} 
Economic restructuring and globalization are both 'blind' processes in the sense that, for the individual worker, little or nothing can be done to tame the way they unfold or to control their consequences. Macro processes are perceived to demand macro intervention, and polls in Brazil always find that the state (or government) is the only agent capable of solving major problems such as unemployment, income inequality, or poverty. This may help to explain why the PSS survey did not detect differences in attitudes between union and non-union members concerning most of these issues in the questionnaire. The survey suggests that unions are not perceived as part of the solution to workers' individual or collective problems, even though affiliation to unions is indeed an indicator of work and economic security. In fact, unionization indicates job and work security, but does not seem to be closely related to workers' perceptions of the structure of social and economic problems, or of related solutions.

In this respect, and as a concluding remark, I would say that if union affiliation can be taken as an indication of proximity between a worker and his or her representative institution, unions appear to have lost one of their most important features, that is, the capacity to function as centres for the promotion and reproduction of worldviews, social identities, and political action. That unions do indicate economic security has much to do with the fact that they enrol formal sector workers. The formal sector is synonymous with registered, full-rights jobs, and even though unionization appears to have an independent impact of its own on the probability of having a permanent contract and on the rate of access to legal and contractual rights, this impact is small in quantitative terms as compared to formal

was the main measure that the government should take to face the economic crisis. See the newspaper Folha de São Paulo, 17 February 1999, p. A5. 
sector measures. Union and non-union members equally find themselves very badly represented by the political system, a situation which suggests that unionization is not an indication of political inclusion and voice representation. Workers' perceptions regarding the legitimacy of political institutions are an important finding of the survey, and they add to the major hypothesis of this chapter, which states that unions were dislocated from the centre of the Brazilian political arena in the 1990s. This dislocation does not need to be irreversible, though. The future is not always predicated in the present, as the events of September 112001 have shown, and as the crisis in Argentina has recently reaffirmed. In both cases politics (or the State) is back in the scene. 


\section{CHAPTER V \\ BRAZILIAN LABOUR MARKET: LIMITS AND OPPORTU- NITIES FOR EMANCIPATION ${ }^{1}$}

\section{Introduction}

In the ten years ended roughly in 2013 Brazil figured in the world market radar as a credibly emergent economy. High levels of GDP growth, favourable foreign trade leading to high levels of international reserves, job creation to nearly full employment, a politically led and efficient program of income's distribution and alleviation of poverty, rising individual and family income, public investment in infrastructure and social policies, all that alongside the maintenance of strict liberal macroeconomic rationale: fiscal austerity, inflation targeting, Central Bank autonomy, free and floating exchange rate market, and free financial market as a condition of the entire scenario.

It is not without surprise that novelty is the recurrent word in mainstream economics and also in part of the sociological reasoning on the (incontestable) recent process of economic growth and employment creation. In fact, during the entire

1 Published for the first time in Pieterse and Cardoso (2014: pp. 64-82). This is an extended and revised version. 
1990s the alleged rigidity of the Brazilian labour market has been reputed as an obstacle to economic restructuring in a globalized world (Pastore, 1997; Amadeo e Camargo, 1996; Heckman e Pagés, 2000) and, hence, to economic prosperity. Thus, like many other Latin American countries that adopted the Washington Consensus recipes, the Fernando H. Cardoso's government (1995-2002) did introduce a series of flexibility measures to fight unemployment and create jobs ${ }^{2}$, but unemployment more than doubled in his eight year period, reaching over $20 \%$ in some metropolitan regions, and 8 out of 10 of all jobs created during his term were informal jobs. The Lula administration, on the contrary, reduced the effectiveness of some of the flexibility arrangements, and from 2003 to 2010 the figures were mirrored: 8 out of 10 new jobs were formal ones, totalling 16 million in 8 years, as against less than 2 million under Cardoso's administration.

While recognizing the deep changes underway and the effectiveness of economic growth and of the job creation policies, my intention here is to take them cum grano salis. In spite of the obvious improvements in the dimensions just named, the country has to face considerable social, economic and demographic inertia resulting from long lasting economic stagnation and poor growth rates, which have affected successive generations in the last 30 years or so and have created an unprecedented and complex labour market dynamic which is seldom taken into account in mainstream analysis and public debate. On the one hand, a significant proportion of the 40

\footnotetext{
2 Amongst the flexibility measures we can name the legal institution of flexible working hours, incentives to increase the variable proportion of wages (via institution of workers' share in profits, productivity bonuses, fringe benefits etc.) reduction of dismissal costs, incentives to collective bargaining instead of the protection of the labour law and many others. See Cook (2007) for a Latin American perspective on liberal labour market flexibilization. A good critical assessment of the trade-off flexibility x employment creation is Bensusan (2006).
} 
per cent of the labour force informally occupied in 2009 are no longer employable in the formal labour market ${ }^{3}$. That is, they are not demanding and will not demand a formal, salaried job in the growing economy, for they are too old and have stayed for too long in either own-account ${ }^{4}$ or informal salaried positions which have selected them out of the competition for the new jobs. On the other hand, the growing formal labour market is not creating enough jobs to accommodate the new generations of workers, who must still face long periods of unemployment or of precarious informal jobs before they are 'entitled' to a formal position. And this position, once attained, is unstable for most workers, representing spans of formal relations intercalated with informality, unemployment or discouragement. If things are much better today than they used to be for much of the labour force, its stability and sustainability, if proven in the future, are no guarantee of better labour market positions for what I call here the lost generations which had to make their living in very precarious economic environments in the past, thus burning the bridges to the world of formal work relations, which opens the doors of work-related legal and State protection. This means, on the one hand, that they will increasingly depend on the circulation of the wealth produced elsewhere, of which they will get a share via the (unskilled) services most of them provide and the (low quality) consumer goods they transform as own-account (or self-employed) workers; and, on the other hand, as they grow

3 On similar lines, see Baltar et al. (2010).

4 In Brazil own-account work means work in one's own business, exploring an economic activity without employees, either individually or with a partner, with or without the aid of non-salaried worker(s). See http:// www.ibge.gov.br/home/estatistica/populacao/condicaodevida/ indicadoresminimos/conceitos.shtm. Own-accounting is traditionally associated with low income and informality, although a recent increase in entrepreneurship in the country is creating a new own-account stratum at the top of the income's distribution. I will return to the point in this chapter. 
older, they will more and more depend on State redistribution and compensatory policies and on family members' support. This social inertia must be taken into account in any serious discussion on our future ${ }^{5}$.

In this chapter I will offer a long run perspective on the characteristics of the Brazilian labour market, in order to scrutinize its present dilemmas and inquire on its future prospects. I start with some stylized facts on the economy in the last 70 years, move to an in depth analysis of changes in the labour market probabilities of men and women of different age groups in the last 30 years, and scrutinize the employment quality of different categories of workers, most especially formal sector salaried ones. I also add some remarks on work mobility to demonstrate both the flexibility and the precariousness of the formal labour market, the social base of the current socioeconomic 'prosperity'.

\section{Promises and expectations}

It is common wisdom that the Brazilian labour market has historically offered precarious jobs, both in urban and rural areas $^{6}$. Precariousness here means long working hours, unhealthy working conditions, despotic work regimes (Burawoy, 1979), unskilled jobs, high turnover rates and low salaries. These resulted from a combined effect, in the last hundred years or so, of highly concentrated land ownership, export-oriented agriculture, low levels of industrialization, high internal rural-urban migration rates

\footnotetext{
The same problem can be found in India, though probably less in China. In India life expectancy is increasing fast and is about to overtake that of western rich countries (ILO 2011). Most of the older workers have not contributed to social security systems, for they've lived in the informality for their entire lives. In Brazil, as will be seen, the experience of a formal job was fulfilled here and then for many, but never universalized as a stable condition.

6 See Oliveira (1972), Cardoso (2010).
} 
and low investment in education, among other things. The slow emergence of a regulated urban labour market after the 1930 s has attracted masses of miserable rural migrants with high levels of illiteracy ( $80 \%$ or higher) in search of better living conditions, or of what I call the 'promises of the labour and social rights' (minimum wage, protected jobs, access to social security systems, health and education services) which the new urban areas were simply unable to accommodate (see Chap. 2).

That is, the pattern of industrialization based on imports' substitution has been unable to create enough urban jobs to accommodate the migrant masses. Besides, the jobs created were far from capable of matching migrants' expectations of better living standards ${ }^{7}$. Many would refuse to work under the offered conditions and salaries, while others accepted precarious jobs just to 'make a living" ${ }^{8}$. The combination of large population flows and poor labour market conditions has generated a long-term population inertia characterized by high levels of poverty, underemployment, informality and social and economic deprivation. In 1981, 48 million people, or $40 \%$ of Brazilians were still under the United Nation's poverty line, and the proportions would climb to 43\% in 1993 (reaching 61 million people), although going down to $35 \%$ in $2001^{9}$. It is true that the figure was reduced to $21 \%$ in 2009 (yet comprising 39.6 million people) in the recent process of poverty and inequality alleviation (Medeiros et al. 2014), but, albeit important in historical terms, it is still not evident weather this reduction will continue in the future due to the current global crisis and to some structural limits of the Brazilian economy and labour market.

Important studies on the frustration of rural migrants in emerging urban labour markets are Lopes (1960 and 1967).

8 A good and still compelling argument on the matter is Machado da Silva (1971).

9 Souce: IPEADATA (www.ipeadata.gov.br). 


\section{Economy and labour}

In 1940, 65\% of the Brazilian Economic Active Population (EAP) were occupied in agriculture, while 10\% worked in manufacturing, construction and mining. In 1980 the figures were $29 \%$ and $25 \%$ respectively. This was the peak share of the three latter industrial groups in employment. In 1990 they occupied $22 \%$ of the EAP (15\% in manufacturing), and $19 \%$ in $2000(12 \% \text { in manufacturing })^{10}$. Manufacturing alone occupied $13 \%$ of the workforce in $2009^{11}$. In terms of employment, then, Brazil has never been an industrial society. It is true that manufacturing, construction, mining (oil included) and urban utilities departed from 25\% in 1950 to reach a peak of $44 \%$ share in the Gross Domestic Product (GDP) in 1980 (see Table 10). But that share is declining ever since. Manufacturing's participation was of mere 15,8\% in 2010. Either in employment or GDP, manufacturing has occupied a subordinate position in most of the country's recent economic history.

${ }^{10}$ Data from decennial censuses, in IBGE (2003).

${ }^{11}$ Data from the National Household Sample Survey (PNAD). 
Table 8. GDP by Economic Sectors (per cent share) - Brazil, 1950-2010

\begin{tabular}{|l|c|c|c|}
\hline Year & Agriculture & Industry(a) & Services(b) \\
\hline 1950 & 25.08 & 24.96 & 49.61 \\
\hline 1960 & 18.28 & 33.19 & 48.69 \\
\hline 1970 & 12.35 & 38.30 & 49.78 \\
\hline 1980 & 10.89 & 44.09 & 44.46 \\
\hline 1990 & 8.10 & 38.69 & 52.66 \\
\hline 2000 & 5.60 & 27.73 & 66.67 \\
\hline 2010 & 5.77 & 26.82 & 67.41 \\
\hline
\end{tabular}

(a) Includes manufacturing, construction, mineral extraction and urban utilities; (b) Includes commerce. Untill 1970, excludes finance intermediation; Source: IBGE Department of National Accounts

Personal services and small commerce prevailed in the urban job creation dynamic. As a consequence, the Brazilian labour market has always been flexible and precarious over time. That is, the country's labour market is not characterized by increased precarity or 'flexibilization' of previous universally formal and regulated work and labour relations. These terms are common in the literature on labour market transitions during the recent neoliberal wave in the OECD countries ${ }^{12}$, meaning $a$ process of deterioration of previously regulated and 'good' jobs. It is true that urbanization in Brazil has meant increasingly better (but still very bad) labour market conditions until the mid-1970s, when the rate of urban formal employment approached 60\% of the EAP (Cardoso, 2003). But this has proven a ceiling for the rate of formal labour relations, which fell to near $50 \%$ and stayed there during the 1980 's, and was reduced to near $42 \%$ in the 1990 s just to return to the $50 \%$ level in recent years.

${ }^{12}$ For instance, Castel (1998); Standing (1999); Sennet (2003); Standing (2012). 
To be formally or informally occupied is not a minor distinction in Brazil. Formal jobs grant access to myriad constitutionalized labour rights, and despite the fact that the costs of non-compliance with the law have historically been either low or null for employers (as will be seen in the final Chapter), the rate of compliance has probably been over $90 \%$ of the formally occupied labour force in the last two decades ${ }^{13}$.

A formal job is also a 'better' job in terms of income, skilling and job security. Considering the 1992-2009 period, formal salaried workers earned more than twice as much as informal salaried ones, no matter if men or women. The mean ratio to self-employed workers in the period was of 1.66 for men and 1.48 for women in favour of formal wage earners ${ }^{14}$. Formal workers also had two to three more school years than informal ones, and a formal wage earner would stay 36 more months (if woman) and 22 more (if man) in the same job than an informal one. However, the probability of getting a formal job and staying in it is not the same for all workers, and it competes with a series of other, less 'virtuous' social identities and possibilities.

Looking at the picture with a magnifying glass, Graph 3 shows the structure of labour market probabilities of men of different age groups, according to the types of jobs or occupational positions available from 1981 to 2009 in Brazil ${ }^{15}$.

\footnotetext{
13 The number of workers' demands at the first level of the labour courts varies from 2 to 2.5 million every year, for a formal occupied population varying from 25 to 42 million in the last 20 years.

${ }^{14}$ Data from National Household Sample Survey (PNAD). The differences are shortening. In 1992 a formal employee earned almost three times as much as an informal one, a ratio reduced to 1.8 in 2009, still an important difference. Formal wage earner to own-account ratio was reduced from 1.94 to 1.57 (men) and from 1.78 to 1.39 (women). In any event, all ratios have been fairly stable over the last 5 years.

15 The source is the National Household Sample Survey (PNAD). Due to space limits I will only analyse men's probabilities in depth. The picture for women is very different and will be discussed in passing later.
} 
Each layer in each sub-graph depicts the changing positional probabilities, year by year, of a particular age group in the specific job type or social condition. From bottom up, the first layer shows the probability of being in a formal, registered (either public or private sector) job. The subsequent one shows the probability of having an informal, unregistered salaried job in the private sector (by definition, public sector salaried jobs are always formal); the third layer depicts informal own-account jobs; then comes formal own-account workers, that is, self-employed men who contribute to a social security system; then come the employers, followed by unpaid workers, unemployed and men out of the Economically Active Population (EAP). Reading the data from left to right in each sub-graph, the probabilities of a particular age group occupying one of these positions vary over time, and the graphs depict the entire, grouped probabilities for all men of 20 to 59 years of age.

The probabilities for each age group look very stable over time, but some movements must be underlined. In 1981, a 20 to 24 year old man had a chance of near 45 percent of being in a formal job. By mid 1980s this had grown to nearly 50 percent, in what appeared to be a process of labour market structuration and improvement. However, after 1986 the figures fell steadily until a nadir of meagre $34 \%$ in 1999 . The probabilities would then rise again to near $45 \%$ in 2009 , that is, the same figure of the first year in picture (1981). For all age groups the movement is basically the same, though at different probability levels: the 25 to 29 and 30 to 34 year groups start the period at a $50 \%$ level, grow to $53 \%$, fall to around $42 \%$ and rise back to over $50 \%$. The older group here depicted start at a $26 \%$ level, goes up to $30 \%$, down to $22 \%$ and back to $27 \%$ of formal employment probability. This means that, after three decades of economic turbulence (including the 1980s 'lost decade'), economic restructuring in the 1990's followed by 
deep economic crisis and then by the recent growth period, any men of 20 to 59 years in 2009 had basically the same chances of getting a formal job than their age group peers of 1981. And the probability was almost always below $40 \%$ except for a man of 30-34 years.

Since we're analysing different generations entering the labour market in different points in time, what is important here is that probabilities in a given point are not neutral with respect to future labour market prospects of each age group. We know from literature that an unemployment spell has further consequences for a young person's career; duration of unemployment is also important, and so is the type and quality of the first job attained. Bad labour market conditions resulting from economic crisis create period effects affecting all workers in a given historical juncture, but with different consequences over time for different age cohorts, a person's skills, sex and other intervening factors ${ }^{16}$.

For instance, a good proportion of skilled workers who lost their jobs in the metallurgic belt of the São Paulo Metropolitan Region during the 1981-1983 recession have never returned to a formal job again (Hirata and Humphrey, 1989). We also know that the economic restructuring of the 1990s destroyed near 1.4 million formal jobs in manufacturing in Brazil (Sabóia, 2000). These jobs were not recovered before the mid-2000s, and the manufacturing workers that had lost their jobs were now too old to be 'employable'. As a matter of fact, considering autoindustry workers dismissed after 1989, less than 50\% would ever find another formal job again (Cardoso, Comin and Guimarães, 2004) and the older the worker, the less likely it was that he or she would do so. Thus, it is important to consider cohort and period

${ }^{16}$ Literature on the matter abounds. A good study for the case of England is Purcell et al (2007). For Brazil, Guimarães et al. (2008). 
effects jointly in the analysis of labour market probabilities and impacts on workers' life cycles. I will return to this later.

Another general and important movement of the global probabilities of men is the fact that informal salaried positions are constantly reduced over the life cycle in favour both of formal salaried and self-employment, no matter the period (or year). Informal salaried relations are important entry conditions for younger men, and lose importance as they grow older. Probabilities were around $22 \%$ or more for the youngest age group, and of $12 \%$ or less for the oldest group here depicted, no matter the period in the 1981-2009 time span. On the other hand, for each age group, the probabilities of an informal salaried job are basically constant over time. In other words, people aged 30 to 34 years in 2009 had the same probability of their 1999, 1989 or 1981 peers of being informally occupied, varying very little around the mean of $16.4 \%$ (standard deviation of less than 1\%). The proportion is basically the same for the 40-49 age group.

The combination of these two probability movements (reduction with age and stability over the 30 year period for any age group) does suggest that informal salaried relations are transitory conditions for a fair proportion of the younger workers, who take them while waiting for a better, formal position. This seems to be evidence that this structure of job positions actually offers opportunities for job and social mobility, since informal salaried jobs are traditionally worse paid than the other two categories. For a portion of the younger men entering the labour market, then, it presents itself as a structure of opportunities of mobility that is actually instantiated during a person's life cycle.

But the sequence of graphs offers other crucial evidence. For all age groups, men's probabilities of being either unemployed or out of the EAP (the upper two layers) increased importantly in the last 30 years. For the youngest age group 
of men, if we include the probability of being in an unpaid job, after a nadir of 17\% in 1990, the joint probability of these three positions grew to $30 \%$ in 2003 , when it started to fall again, but only to reach $26 \%$ in 2009 . If this can be taken as a measure of bad labour market or life cycle positions ${ }^{17}$, all age groups were worse off in this particular matter in 2009, compared to 1981 . The least affected were 30 to 40 year old men, but even for them these three positions' probabilities increased from $5 \%$ to $10 \%$ in 30 years.

${ }^{17}$ It is true that part of the young men out of the EAP were actually studying. So, for them being out of the labour market is not necessarily a 'bad' condition as compared to older men in the same situation. 
Graph 3. Type of job by age groups: men of 20 to 59 years Brazil, 1981-2009

20 to 24 years

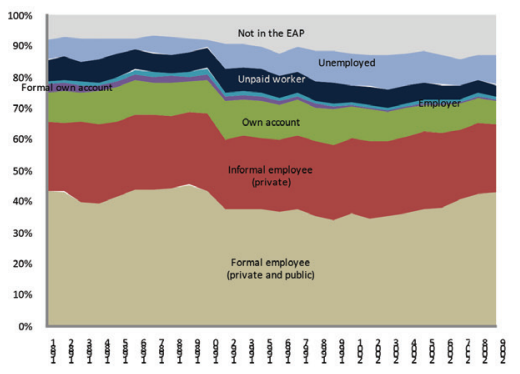

30 to 34 years

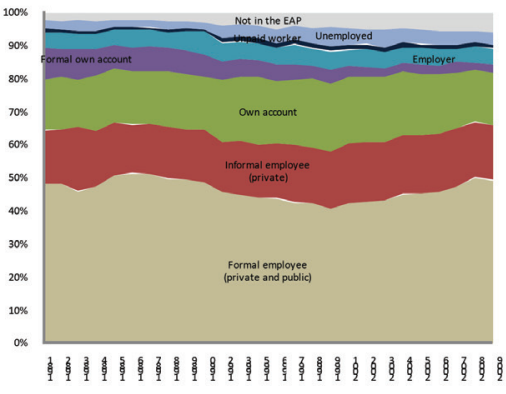

41 to 49 years

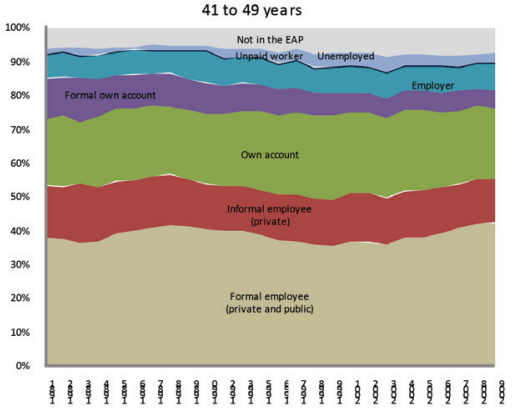

25 to 29 years

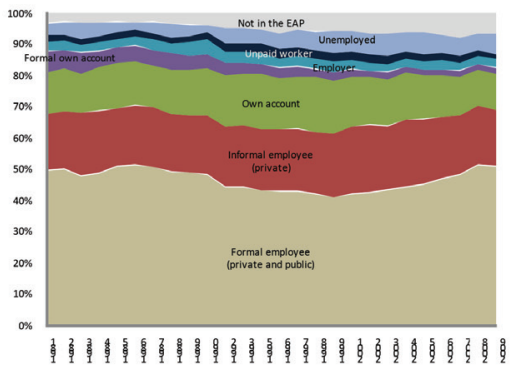

35 to 40 years

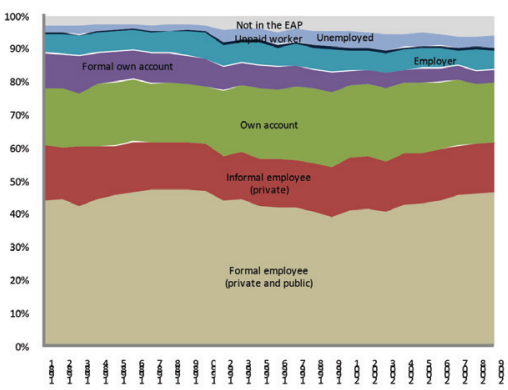

50 to 59 years

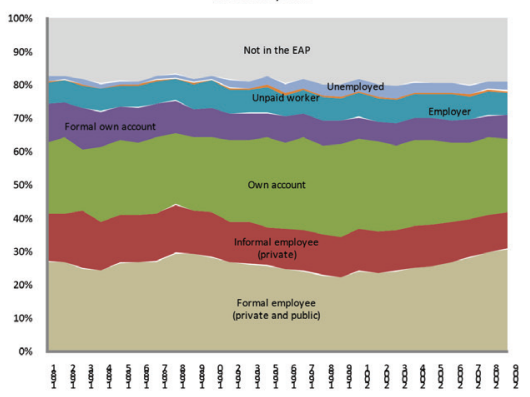

Source: National Household Sample Survey (PNAD), 1981-2009 
Note also that, as men grow older (that is, comparing the age groups vertically in the graphs' set), there is a clear exchange between formal and informal salaried probabilities, on the one hand, and own-accounting, on the other. For each older age group, the proportion of the first two positions shrink while own-accounting grows, and that includes both formal and informal own-account jobs.

The message so far seems straightforward: The peak 'virtuous' labour market age for men in Brazil is from 25 to 34 years. Here we have maximum participation in the EAP, the minimum unemployment rate, and the higher proportion of formal positions (if we include formal salaried and own-account jobs, and employer positions). Younger and older age groups have relatively higher (sometimes much higher) probabilities of being either out of any job or in an informal job. In any case, lifecycles are marked by a structure of occupational opportunities that is very age specific and which worsens importantly with age. Aging has not been synonym of work-based ontological security so far for a very large proportion of the EAP. And most importantly, recent labour market improvements have not fundamentally changed this outcome. Before elaborating on the consequence of this for the current debates on economic recovery and social change, I must scrutinize the quality of formal jobs.

\section{Quality of jobs}

One important indicator of the quality of labour market conditions is the degree of stability of the existing positions. If bad jobs (in terms of income and labour rights) are attained for large periods of time, they must be taken as the very boundaries of the social classification possibilities of their occupants. For instance, informal salaried relations' probabilities are reduced as people grow older, as we've seen, but those who are found in 
these positions at the age of, say, 45 years, have most probably been there for quite a long time, and the precarious positions will not only have scratched a scar on their past lives, but will also weigh on the workers' future. To analyse this, Graph 4 shows two complementary scenarios of men's labour market positions. On top, we see the mean duration of employment in months, of all men of 15 years or older occupied in Brazil from 1992 to 2009 ${ }^{18}$; and on the bottom, the employment duration of those of 40 to 49 years of age. We can see, first, that employment duration of all categories is increasing over time, though at different paces. Own-account workers (formal and informal) and employers stay much longer in their positions than the other three categories, and duration increased importantly throughout the period. In 1992 their mean job duration varied from 135 (formal own-account) to 150 months (employers). In 2009 duration had increased to 150 (informal own-account) to 170 months (formal ones). For the other three categories there has been a slighter increase, and at lower duration levels: from 75 to 85 months in the case of formal employees and unpaid workers, and below 60 for informal salaried jobs. This is evidence of the transitory character of the latter for a fair part of the labour force. It also means that own-account jobs are a repository of labour to be mobilized by an expansion of labour demand due to economic growth, but a repository with clear oversupply.

In fact, the second part of the graph shows an important increase in the job duration of own-account workers of the 40 to 49 age group, from less than 150 in 1992 to almost 170 months in 2009. Comparing this figure with Graph 3, above, in which a proportion of own-account probabilities were transferred to formal employment after 2003, the increase in own-account

18 The question on time in the current job was introduced in the National Household Survey in 1992 only. 
duration results from a selection of longer lasting jobs in this category. In other words, those who moved from own-account to formal employment were people that were relatively neophyte in the former position, probably waiting for a salaried formal job when the opportunity arose. This is expressed, in reversed mode, in the slight reduction in the mean duration of formal jobs after 2003 (from 120 to 116 months) in this particular age group, reflecting the entry of new occupants in the jobs then created $^{19}$. In the same direction, older workers remain longer in informal salaried positions than the others. Here too there seems to have happened a selection process after 2003 , for job duration increased from the 'historical' figure of 80 to almost 110 months. This is why I said that if a 45 year old man is found in this position in 2009, he has probably been there for quite a long time, and was selected out of the probability of entering a formal position.

${ }^{19}$ I've selected this age group for the clear exchange of informal to formal positions after 2003, clearly reflected in changes in job durations. But the movement was also detected in the other age groups, most especially from 25 to 39 years. 
Graph4. Mean time of employment (months) in the current job, by type of job. Brazil: 1992-2009.

Men of 15years or older

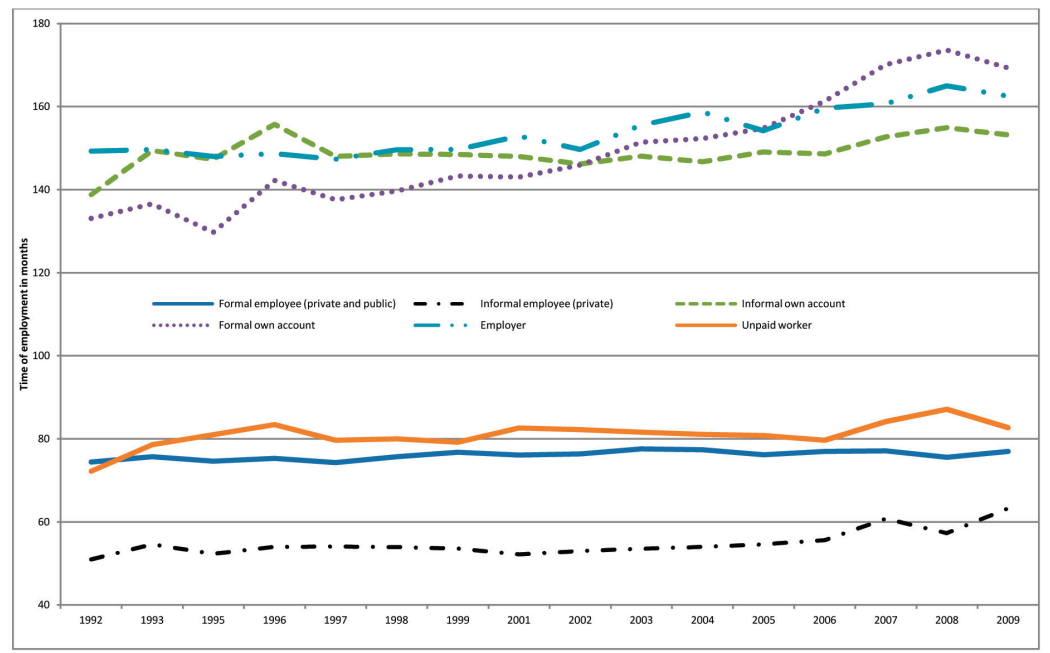

Men of 40-49 years or older

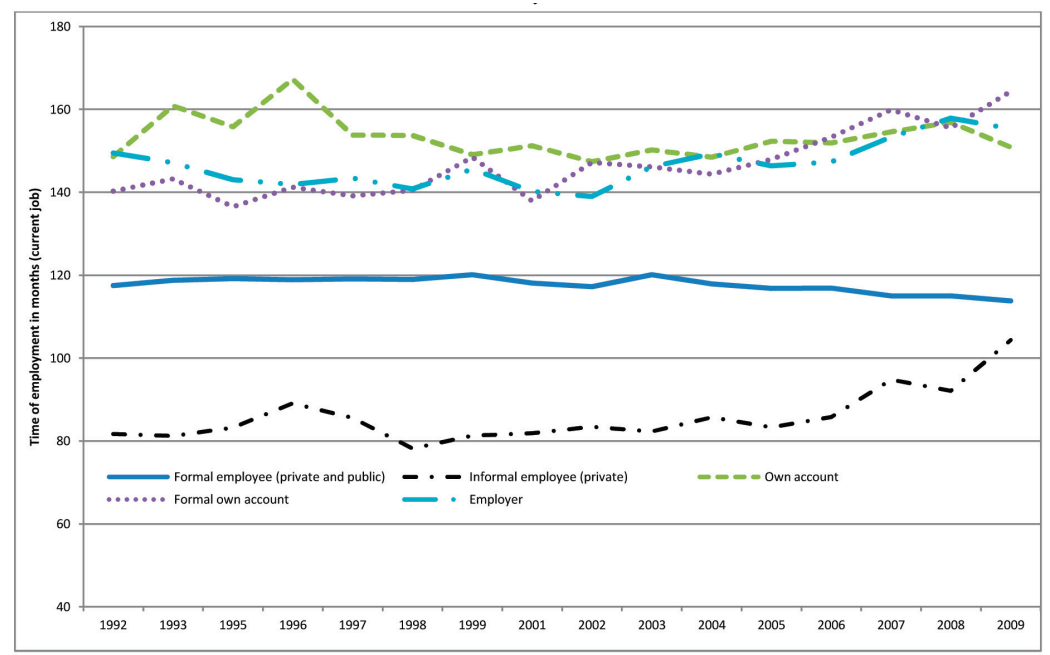

Source: PNAD 
Taken together, these figures seem to be telling the following story: Workers tend to stay less longer in 'good', formal jobs, especially in private ones, and longer in informal, own-account positions. The economic recovery after 2003 has generated 11.5 million new formal jobs until 2009 (including public and private sectors $)^{20}$. These were distributed mostly among the population already occupying an either formal or informal existing position. New entrants also got a share of it, but the increase in the unemployment rates of younger age groups (seen in Graph 2) suggests that they benefited much less than those with longer labour market experience ${ }^{21}$. This also tells a story of job mobility and labour market fluidity (or flexibility), since the joint probabilities of different positions are changing for all age categories at the same time.

These figures call attention to an important characteristic of the recent changes in the Brazilian labour market. Job mobility from informal to formal positions is apparently restricted to the fringes of the two major informal categories (unregistered salaried and own-account jobs). These fringes were composed of workers with less labour market experience and lower salaries than those that stayed, or were selected out of the possibility of getting a formal job. This contributed to increase the median salaries and the job duration of those who survived in the worse positions, while reducing the duration of the new formal jobs, which were occupied in part by previously informal workers in search for better salaries and benefits in formal positions. But all this happened to a very small fraction of the labour force, though fairly well distributed within the age categories. Only

${ }^{20}$ According to the National Household Survey analyzed here, there existed 29.5 million formal salaried positions in the country's labour market in 2002. In 2009 this had grown to 41 million.

${ }^{21}$ As a matter of fact, $70 \%$ of the new formal jobs created in the period were occupied by people of 30 years of age or more, according to the same PNAD. 
$10 \%$ to $15 \%$ of the joint distribution of job type probabilities for men moved from one category to another in recent years, with formal jobs in 2009 returning to the proportion they had in 1981. This has not been enough to change the enduring and entrenched structure of probabilities of getting a job, which is still characterized by precariousness and insecurity. For instance, according to the same 2009 PNAD, four occupational groups accounted for $75 \%$ of the 40 to 59 year old informal own account jobs of men: agriculture (30\%), construction (25\%), sales $(15 \%)$ and driving $(6 \%)$. Formal own-account in the same groups were $63 \%$. Sales occupied $1 / 3$ of informal own-account women, and $30 \%$ of formal ones. Most importantly, a larger proportion of this aging labour force is staying longer in these dead-end jobs, which cannot be treated as a passage point for workers waiting for a better fate. They are the destiny of the large majority of them.

Here I must add one last word on the matter. Let us return to Graph 3, above, which shows a slight increase from $17 \%$ to $20 \%$, in the 29 -year period, in the proportion of the 50-59 year old men who were out of the EAP. This is an enormous proportion if we consider that, for any contemporary standards, in most countries a 50 or 55 year-old man is normally economically-active, in full-time employment. It is true that workers enter the labour market at a very early age in Brazil, and some of them also retire early. But legislation changed in recent years, and a worker in the private sector needs to have contributed for 35 years to the social security system and must be at least 65 years old to be entitled to a retirement pension. So, some of these men are probably former public servants who could benefit from special retirement measures which have not changed yet. What is important, however, is that $62 \%$ of those out of the EAP in the 50 to 59 age group were 
retired or earned a public pension in $2008^{22}$. And here is the most striking information: $70 \%$ of the latter had some kind of serious, more or less incapacitating physical disability, which most probably explains either the retirement or the pension subsidies they received ${ }^{23}$. The proportion of disabilities is far higher than that of the total working population (around 10\%) and even of that of the formal salaried workers in that age group $(14.4 \%)^{24}$. This information adds to the general picture of a labour market which is not only historically precarious and unstable, but also unsafe for a good part of the workforce; those forced out of it or whose productivity is restricted for health reasons ${ }^{25}$.

\section{Women: a different scenario?}

Women's probabilities have historically been very different from men's, despite some convergence in recent years. I will add a few remarks on this to clarify important elements

${ }^{22}$ I chose 2008 to investigate this category because in this year PNAD included a very comprehensive supplement on health.

${ }^{23}$ Disabilities measured by PNAD include a person being incapable of, or finding it very difficult to feed him or herself, bathe, kneel, walk up a slope, bend, walk a kilometer and others. A man is entitled a pension if he is incapacitated for work due to proved physical incapacities. Women normally get pensions from their deceived fathers in special conditions. Retirement requires a time of contribution (35 years for men, 30 for women) plus a minimum age, now set at 65 years for men and 60 for women. Around $47 \%$ of the retired workers of the targeted age group (50-59 years) earned the minimum wage in 2008 (near US $\$ 300.00$ per month), that is, a subsistence income.

${ }^{24}$ Actually, the proportions increase as the type of job worsens. Formal ownaccount workers had a $13.7 \%$ chance of having a disability at that age group. The other proportions: Informal salaried, 17.6\%; informal own-account, $19.3 \%$; unpaid workers, $26.7 \%$.

${ }^{25}$ For the 40-49 age group, the proportion of retired men with physical disabilities was of $50 \%$ or more, according to the same source. It is impossible to directly attribute retirement to work-related diseases, but literature on the matter abounds showing, for instance, that Brazil is a world champion in work related accidents, injuries and deaths. See Dwyer (2006) for a review. 
of the country's labour market dynamics. The first thing to note is that 15 year old women or older have increased their participation rate in the EAP from $37 \%$ to $55 \%$ in the period of interest here, while men's have decreased from $84 \%$ to $78 \%$. I chose the 30-34 age group to illustrate women's labour market probabilities. Graph 5 shows the increase in this particular group's participation rate (from $42 \%$ to $70 \%$ ) in 30 years $^{26}$. It also depicts the fairly different job probabilities as compared to men's. For instance, the proportion of unpaid workers is much higher among women. The probability of an informal salaried job is increasing for them, while for men it was stable around $16 \%$ during the entire period. Women's unemployment rate is also much higher than men's, and has increased in recent years. Only a small minority of women are employers or selfemployed workers, but the former is also increasing over time. In a word, for women the exchanges in the overall probabilities occur, first, between inactivity and activity; second, between informal own- account and formal salaried relations, on the one side, and informal salaried, on the other side, and this is an indication of the relative deterioration of the joint probabilities for women of this age group. The proportions moving from inactivity to any informal position is always higher than the ones moving to a formal job.

${ }^{26}$ Participation rate means the proportion of women of that age that were either occupied or searching for a job. 
Graph 5. Labour market probabilities of women, 30-34 age group. Brazil, 1981-2009

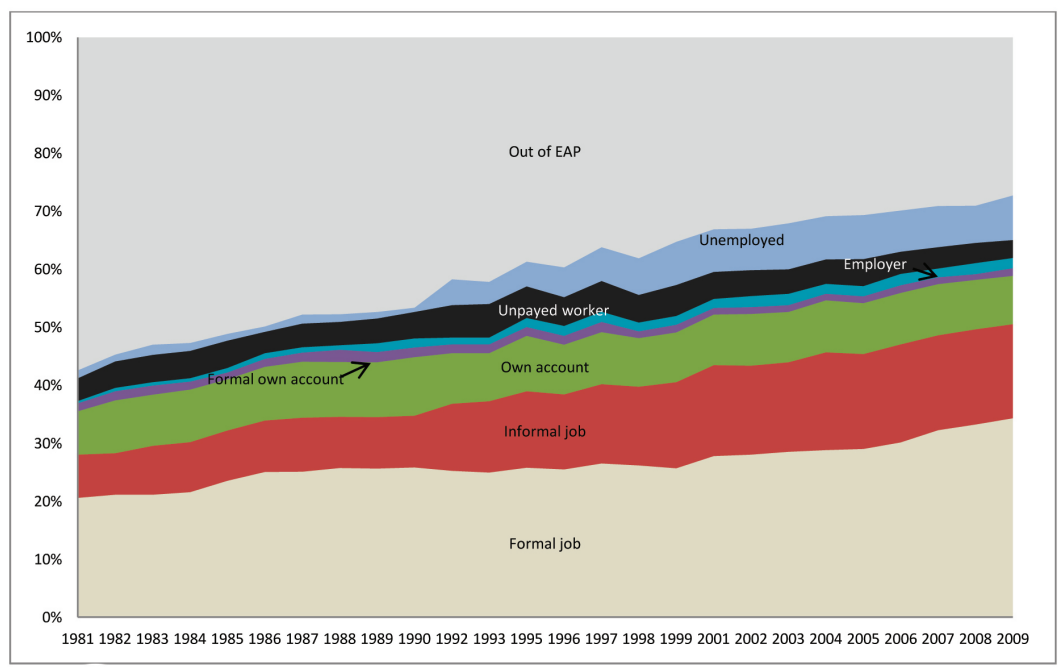

Source: PNAD

Women's participation rate increases while men's decreases. This could indicate an overtaking of men's positions by women over time, and this appears to have been the case from 1981 to at least 2003. Graph 6 depicts the share in salaried formal jobs by each gender group as a proportion of all existing job positions. ${ }^{27}$ In 1981 men had 2.15 times more chances of being in a formal job than women (see the odds ratio curve). In 2003 this had fallen to 1.40 times, and varied little around that mean ever since. Most of the decline occurred during two economic crisis (1980-1983 and 1990-1992), but in the 1990s, while economic restructuring was destroying jobs in manufacturing, women were much less affected, for most of

${ }^{27}$ In this analysis I exclude people out of the EAP or searching for a job. The graph depicts the share of formal jobs in the total distribution of jobs. 
their formal jobs were not in that sector. As a consequence, their share in formal job probabilities kept on increasing while men's decreased fast. In the more recent economic recovery, women are still augmenting their share in the formal labour market, which is much less manufacturing based than in the beginning of the nineties, but this is no longer happening at the cost of men's probabilities. The new growth scenario is creating formal jobs for both sexes.

In other words, formal jobs used to be a man's business in Brazil, but this is no longer the case. At least in this particular respect, segmentation by gender has been importantly reduced, though the odds are still $37 \%$ favourable to men. This, of course, says nothing about gender segmentation by occupation or economic sector, which is persistently high in the country (Bruschini and Lombardi, 2003; Lavinas et al., 2014). Here, I consider the distribution of formal, high quality jobs by gender, and this reveals the improvement of women's conditions over time as compared to men's and, more recently, better labour market conditions for both sexes, even though at a low level of formalization: in 1981, considering formal salaried and ownaccount jobs, and employer positions, formality was a reality for $52 \%$ of the 15 year or older labour force (men and women). In 2009 , this had changed to $55 \%$.

It is hard to say whether men would be better off if women had not entered the labour market at the pace they have. It is well known that discrimination against women is entrenched in relation to the most prestigious managerial and professional positions: they face entry barriers expressed in longer periods of job-search and in the higher formal qualification demanded as compared to men, and they also earn less, though tendered based income inequalities are falling in recent years. However, when women do get a prestige job, they stay longer in it, [thus shielding the place from further competition either from men 
or other women] $]^{28}$. On the other hand, a high proportion of women are domestic workers. At the age of 35 to 49 years such positions were held by $20 \%$ of all economically-active women in 2009, and two thirds of these jobs were unregistered ${ }^{29}$. The proportion for men in these jobs was negligible. Besides, an important proportion of jobs are socially defined as gendered positions, that is, are segregated into either predominantly men's or predominantly women's occupations. Again in 2009, $45 \%$ of economically-active women were in jobs in which the proportion of women in them was of $70 \%$ or higher (in 2002 the figure was identical). At the other extreme, $52 \%$ of men were in jobs in which the proportion of men was of $70 \%$ or higher $^{30}$, but unlike in the case of women's jobs, in 2002 the former proportion had been $58 \%$. This shows that women have been making inroads into previously male preserves in recent years, but for a substantial part of the labour market, men's and women's occupations have remained complementary, with little attempt by either group to challenge gendered occupational segmentation.

${ }^{28}$ I model this strictly in Cardoso (2000).

${ }^{29}$ Domestic work in Brazil is regulated by law, and workers must have their work registry books annotated by employers. But informality is the rule.

${ }^{30}$ Data computed directly from PNAD microdata, and comprises men and women of 15 years or older. 
Graph6. Probability of having a formaljob (\%) bymenand women and the gender odds ratio: Brazil, 1981-2009

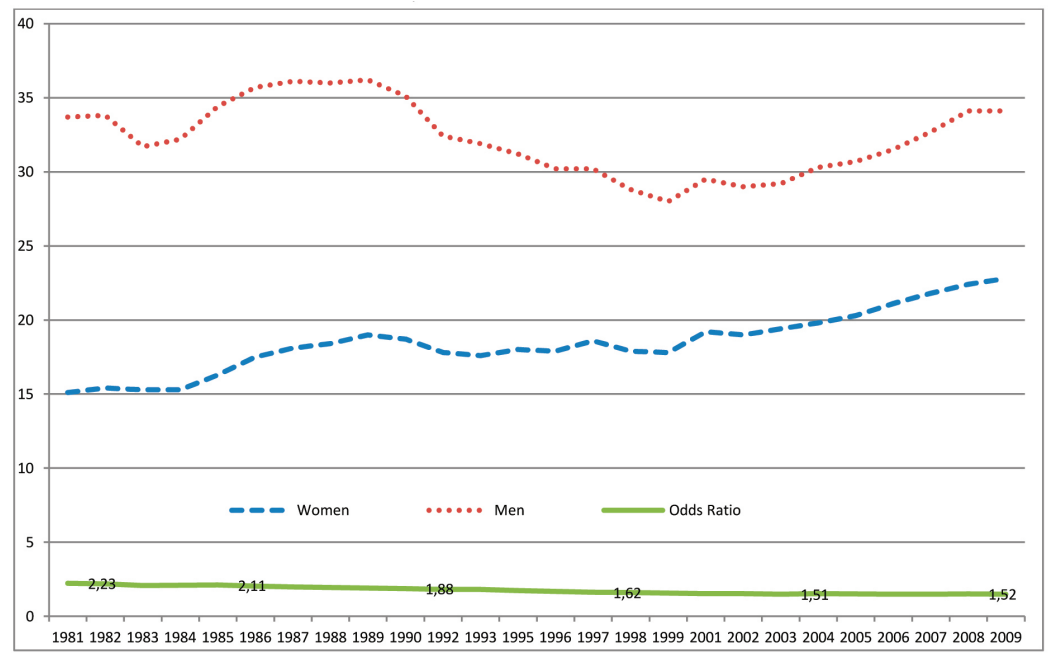

Source: PNAD

Nevertheless, competition from women to enter many male-dominated occupations has certainly been increasing over time, with important impacts on wage differentials and gender related opportunities. In fact, a third element of women's participation worth highlighting is that their median salaries have converged towards men's in the period. Employers' and formal salaried positions showed the lowest gendered wage differentials, no matter the year: $11 \%$ and $23 \%$ respectively in favour of men in 1981, falling to $4 \%$ and $16 \%$ in 2009 . These last figures represent a recovery of men's advantage as compared to the five or ten previous years, but the progress towards greater gender parity was not wholly reversed. However, the most striking decrease in gender inequalities occurred in the informal sector. Informally occupied men's median salaries were $60 \%$ higher than women's in the mid 1980s, and this difference has simply vanished. It is true that formal own-account men have 
fared better after 2005, but this is still to be confirmed by more recent, still not available statistics. In any event, men/women median income inequality fell from a mean of 39.4\% in 1981 to $6.3 \%$ in 2009 , in spite of recent increases within some job types.

Graph 7. Male/female ratio of median hourly earnings by type of job. Brazil, 1981-2009

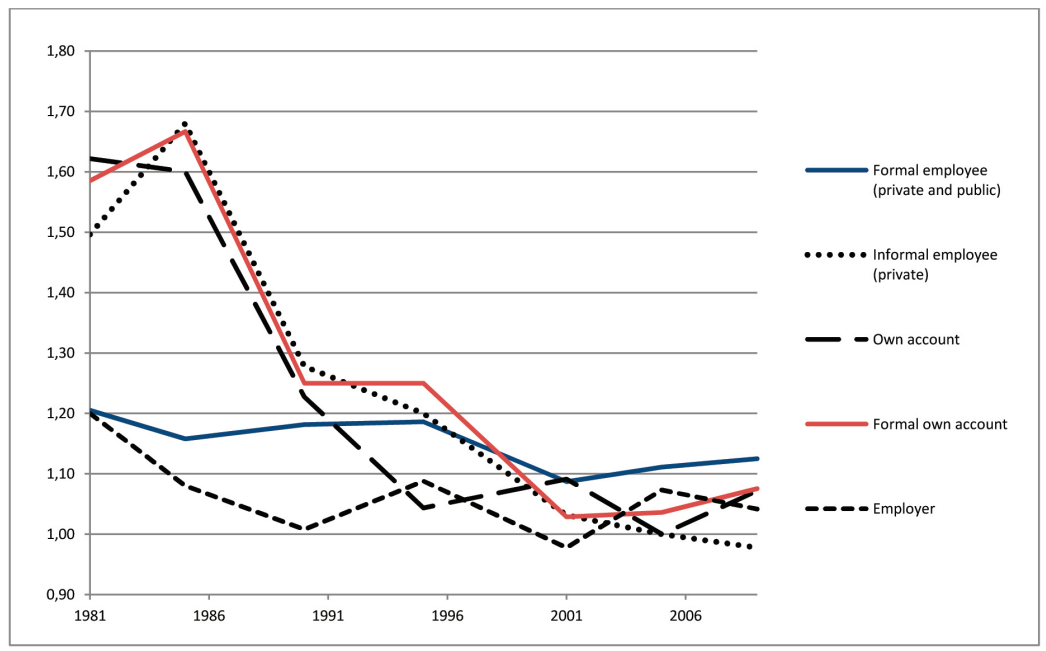

Source: PNAD

\section{Formal sector fluidity}

Accessing the formal labour market is the dream of most workers, for it is (presumably) formally protected and offers a series of benefits that informal positions do not ${ }^{31}$. But we've

\footnotetext{
31 As I show in Chapter 6, this volume, the system of labour regulations offers various incentives to noncompliance, and many employers are recalcitrant evaders. See also Alemão et al. (2009). Filgueiras (2012) is the first to analyze the joint action of the three surveillance mechanisms available to the public authority to assure compliance to the law (labour inspection, labour justice and public labour attorney). Based on vast empirical material, he hypothesizes that the culture of conciliation of the grievances and infractions has a
} 
seen that salaried formal jobs only last longer than informal salaried jobs, with a mean of 75 to 77 months for men in the 1992-2009 period. This is less than half the duration of unpaid, own account or employer positions (see first part of Graph 4 above). Mean duration, however, can be misleading in labour markets defined by entrenched inequalities. And in fact, 43.5\% of formal salaried men had been in their jobs for less than three years in the 1992-2009 period. Variation around this mean was negligible in each particular year (standard deviation of less than $1 \%$ ). Proportions for women were only slightly smaller (41.4\%), with small variation too. That is, from 1992 to 2009 Brazil has simultaneously created and eliminated some 20 million formal jobs depending on the economic context, while women strongly increased their participation in the formal labour market, and some two million entrants competed for existing or new positions every year, while the structure of job duration has stayed fairly stable over time. This configures a pattern in the structure of formal jobs, which are stable positions (lasting 7 years or more) for one third of their occupants only. It is true that age is monotonically correlated with job duration for men and women: each year of duration roughly corresponds to one more year in the life cycles of both sexes. This could indicate that once in a formal job, the person ages in it. But this is not what actually happens.

demonstration effect leading to increased non-compliance, or to a practical flexibilization (and informalization) of formal work contracts due to the low or null costs of law evasion. 
Table 9. Duration of formal salaried jobs for men and women, and mean age in each category. Brazil, mean proportions and age for 1992-2009

\begin{tabular}{|l|c|c|c|c|}
\hline Job duration & \multicolumn{2}{|c|}{ Mean proportions (\%) } & \multicolumn{2}{c|}{ Mean age (years) } \\
\hline & Women & Men & Women & Men \\
\hline Less than one year & 16.4 & 18.5 & 28.5 & 29.5 \\
\hline 1 year to less than 2 & 13.7 & 13.9 & 29.5 & 30.1 \\
\hline 2 to less than 3 & 11.3 & 11.1 & 30.9 & 31.3 \\
\hline 3 to less than 5 & 14.9 & 14.9 & 32.8 & 32.9 \\
\hline 5 to less than 7 & 9.9 & 9.8 & 35.2 & 35.1 \\
\hline 7 years or more & 33.8 & 31.9 & 42.2 & 42.0 \\
\hline & 100.0 & 100.0 & & \\
\hline
\end{tabular}

Source: PNAD

\section{In and out a formal job}

The Ministry of Labour gathers and disseminates panel microdata on work trajectories of workers who had any formal job in the country from 1985 onwards. Analysts can track all formal jobs held by the same person in the period, and this is a powerful tool to scrutinize the actual quality and dynamic of the country's formal labour market. The database is called RAIS-MIGRA Vínculos ${ }^{32}$. Its main limitation is that it gathers information on registered jobs (public and private) only ${ }^{33}$.

${ }^{32}$ RAIS stands for Annual Relation of Social Information; MIGRA is an acronym for migration; andvinculo means link, or employment spell. The dataset is unfortunately underutilized in Brazil, but I've tested its robustness in many articles and books. For instance, Cardoso (2000) and Cardoso, Comin and Guimarães (2004).

${ }^{33}$ Since 40 to $58 \%$ of the jobs in the period were informal, the data loses a good part of workers' substantive trajectory probabilities in terms of economic sectors, occupations and income. Here, I am only interested in the probability of being in a formal job, so, the data is perfectly fit. 
However, the fact that it is panel data enables me to proceed with the analyis that follows. Again for the matter of simplicity, I will analyse young men aged 20 to 23 admitted in two time periods: 1994-1996, and 2002-2004, to show the actual fluidity of formal positions. The first group was tracked from January 1994 to December 2001 and the second, from Jan. 2002 to Dec. 2009. Information is in Graph 8, the apprehension of which demands some explanation.

The graph depicts two mutually exclusive probabilities of the two age cohorts. At any point in time of each of the chosen periods, each 20-23 age cohort is either in a formal job (grey area) or out of it (white area). Note that, with PNAD, we were analysing the probability distribution of the existing labour market positions, irrespective of the people in them over time. Here we investigate the probability of the same group of people being in or out of the formal labour market over time. This, then, is a typical panel study.

Let us start with the first part of Graph 8, that is, young men admitted from Jan-94 to Dec-96. If all workers actually aged in the formal job they finally got, as hypothesized in the previous section, we would expect a gradual upward slope in the curve of incorporation in the formal labour market beginning in January 1994. Besides, in the hypothesis of no period effects (for instance, economic crisis in one of these three years), one would expect the incorporation of one third of the entire group every year up to the peak of one hundred per cent in December 1996. But this is not the case. Some $27 \%$ of the cohort entering in this period got their jobs in January 1994. The proportion continued to increase until near the end of this year to $45 \%$, just to fall two percentage points in Jan-1995. The slope loosens in the subsequent years, and the incorporation is limited to $10 \%$ per year. By Dec. 1996, only 61\% of those who had had any formal job in the Jan-94-96 period were still in a formal job. Economic 
restructuring of the 1990s is clearly marked in the grey area's 'leak' from then on to a proportion of 50\% until the end of the decade, followed by a poor recovery in 2001. The story is basically the same for the young men admitted from 2002 to 2004, with one important difference: they peak at around 65\% and 'leak' down to $60 \%$ only. This means that the period of entry in the formal labour market (the crisis of the 1990s or the recent recovery) had a cost of 10 percentage points for the first cohort's probability of staying formally employed. But this is not the most important thing.

Graph 8. Probability of being in a formal job in two different periods. Men of 20-23 years:

1. Admitted at any time between 1994 and 1996, and position until Dec 2001

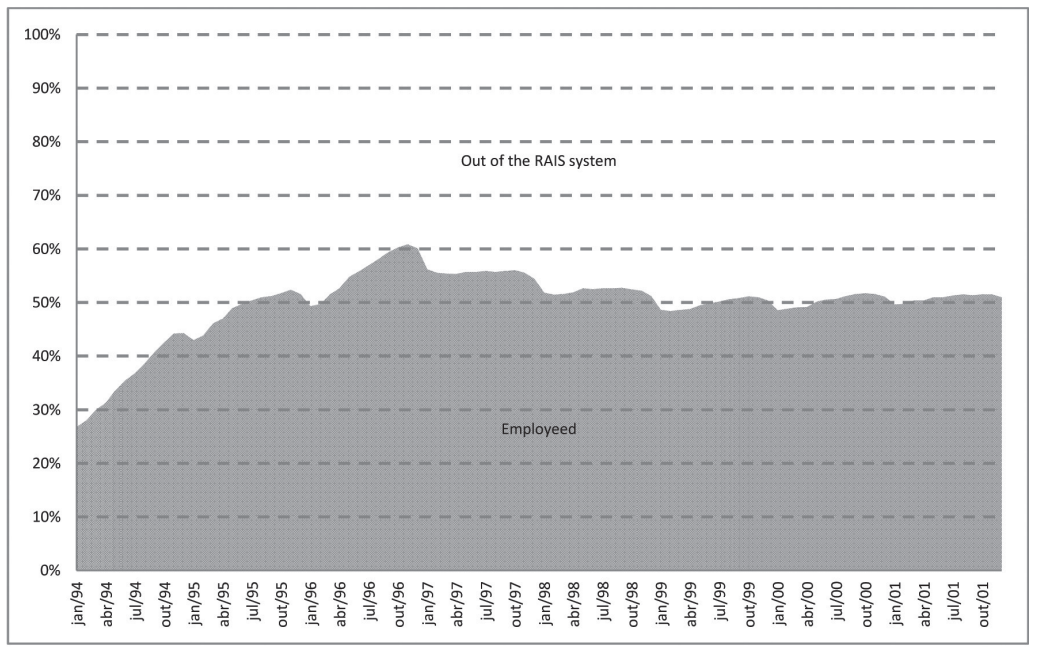


2. Admitted at any time between 2002 and 2004, and position until Dec 2009

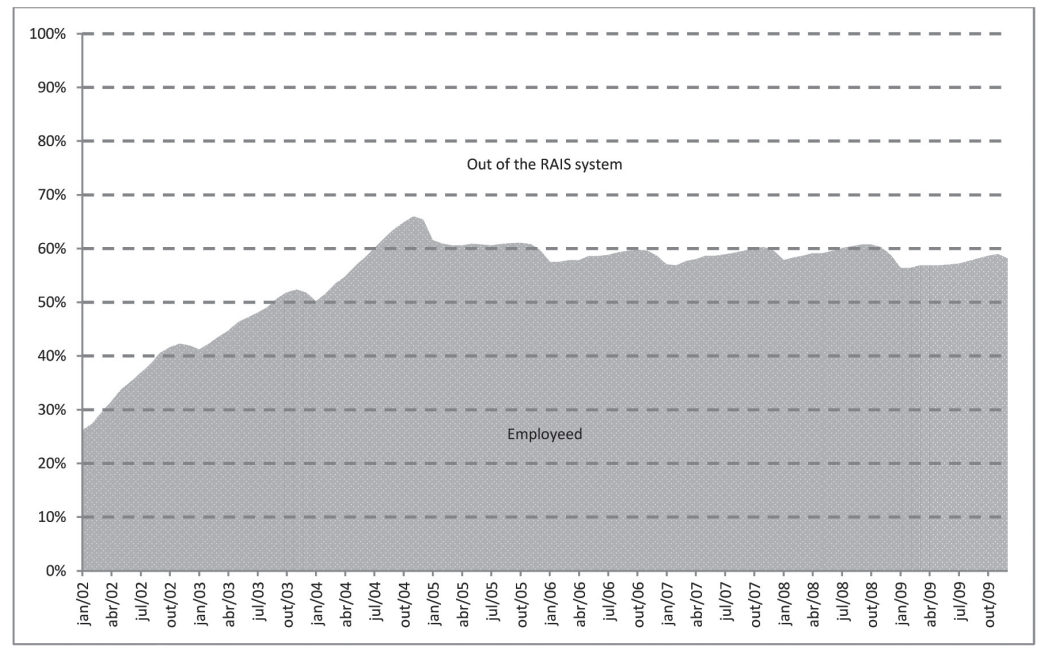

What is striking for our discussion is the fluidity of the formal labour market experience of these men. The ratio of the expected (considering the 'aging in a job' hypothesis) to the actual probability of being employed in the end of the incorporation period is of 1.66. That is, workers had to face a 33\% discount rate of their presumable expectation of survival in the job they got in that period. This means that many were admitted and dismissed during these three years. That is, while others were arriving, the first comers were already leaving. The consequence is that the proportion of occupied men never reached 100 per cent.

It should also be underlined that once dismissed, young workers do not stay out of the formal labour market for life. The rule is quite the opposite. Most of them lose their jobs, stay out for a while and return to a different formal position at some point in time. The 'stable' grey area (with its recurrent leak every January, when firms tend to dismiss workers admitted to cover raised demand during the Christmas period) hides an 
intense exchange between those who are in and out of the RAIS information system. The mean number of jobs of the cohort entering in the 1994-96 period was of 3.6, and the mean job duration, 20.5 months. For the 2002-04 cohort the figures were 3 jobs and 22 months, and in both cases the total time spent in the formal labour market was above 50 months. I don't have the space to go through this here, but if we consider, say, 35 to 39 age cohorts, the picture will be only slightly different, with a more intense downward leak of the grey areas after the peak incorporation years, smaller number of jobs in the trajectory, longer job duration and higher rates of definitive exclusion from the formal labour market, the older the workers.

In a word, the formal labour market is characterized by very high turnover rates. As a matter of fact, the employment chances of different age cohorts are a combined function of job creation and job turnover, with age, sex and race (not covered by RAIS) playing an important, but subsidiary role. New jobs are occupied both by new entrants and by people who have recently lost their previous jobs. And both will most probably lose their positions for others, and very soon.

\section{Regional migration}

Brazil has a national labour market, but not for all workers. For three or four generations after 1930, most of rural/ urban migration history can be told as one of displacement of rural poor workers from the northern and north-eastern to the south-eastern regions of Rio de Janeiro, São Paulo and Minas Gerais, where the promises of a formal, protected job seemed credible. The unfulfilled promises or the hope of a better position elsewhere has always fuelled subsequent migrations, most especially in the case of unskilled men, who would almost always move without their families, which would follow them if 
better conditions were actually found ${ }^{34}$. Much of the country's labour market flexibility is due to the ability of unskilled workers to simply move if life worsens.

Take, for instance, construction workers. Using the same RAIS data discussed in the previous section, we can reconstruct the occupational mobility of anyone who had a formal job in a given point in time in the $1985-2008$ period. For the sake of simplicity I take all construction workers who had a formal job in 1994 in the Rio de Janeiro and the São Paulo Metropolitan Regions, and reconstructed their previous (back to 1985) and subsequent (up to 2008) trajectories. The numbers are in Table 12. For those employed in São Paulo in 1994, all but $85 \%$ had had or would have a formal job in another metropolitan area in the 19852008 period. The figure was of 60\% for those employed in Rio in 1994. Considering the entire formal labour force, the rate of migration was of $64 \%$ of those that had a formal job in São Paulo in 1994, and of $41 \%$ in the case of Rio. Part of this migration occurred between these two geographically close areas (28\% in the case of São Paulo and $40 \%$ in the case of Rio), but many moved to metropolitan regions such as Brasília, Salvador, Fortaleza or Porto Alegre, 600 or 1,000 or 1,500 miles away. Contrary to conventional wisdom, then, the most 'de-territorialized' were not the 'creative', or high skilled workers, but construction workers ${ }^{35}$.

\footnotetext{
${ }^{34}$ I've already noted in this publication that literature on the matter is mammoth. A recent and innovative approach was proposed by Marques (2010), analyzing social networks of poor and middle class citizens of São Paulo and Salvador. Minimum income policies such as 'Bolsa Família' and the recovery of minimum wage's purchasing power are stimulating migrations of return to the original regions of the North and Northeast. These are novel trends in Brazil, and reflect the fact that the northern regions are growing at a 'Chinese' pace $(10 \%$ or more per year), thus creating job opportunities once restricted to the southern areas.

${ }^{35}$ Literature on the de-territorialization of skilled workers is increasing after Florida's The flight of the creative class. In Brazil, skilled people do migrate intensely, as we see in the table, but at a lower rate when compared to unskilled ones.
} 
Many of them have never had the chance to consolidate a family of their own ${ }^{36}$, thus having the liberty to look for jobs elsewhere. But the majority was composed of heads of families who most probably have migrated before calling their relatives in ${ }^{37}$.

Table 10. Total number of Jobs of workers admitted in the São Paulo and Rio de Janeiro Met. Regs. in 1994, according to the original 1994 occupation, and geographical destiny in the 19852008 period

\begin{tabular}{|l|c|c|c|c|c|c|}
\hline \multirow{2}{*}{$\begin{array}{l}\text { Original } \\
\text { occupational } \\
\text { groups (1994) }\end{array}$} & \multicolumn{3}{|c|}{ Origin in São Paulo } & \multicolumn{3}{c|}{ Origin in Rio de Janeiro } \\
\cline { 2 - 7 } & $\begin{array}{c}\text { At least } \\
\text { one job } \\
\text { in Rio } \\
\text { one job } \\
\text { in other } \\
\text { met. } \\
\text { areas }\end{array}$ & $\begin{array}{c}\text { Never } \\
\text { left São } \\
\text { Paulo }\end{array}$ & $\begin{array}{c}\text { At least } \\
\text { one job } \\
\text { in São } \\
\text { Paulo }\end{array}$ & $\begin{array}{c}\text { At least } \\
\text { one job } \\
\text { in other } \\
\text { met. } \\
\text { Areas }\end{array}$ & $\begin{array}{c}\text { Never } \\
\text { left Rio }\end{array}$ \\
\hline $\begin{array}{l}\text { Creative } \\
\text { classes }\end{array}$ & 12,6 & 41,4 & 46,0 & 9,1 & 25,3 & 65,7 \\
\hline Managers & 21,5 & 40,9 & 37,6 & 14,1 & 25,4 & 60,5 \\
\hline $\begin{array}{l}\text { Construction } \\
\text { workers }\end{array}$ & 26,9 & 58,4 & 14,7 & 29,9 & 30,5 & 39,6 \\
\hline Technicians & 25,9 & 41,9 & 32,2 & 22,6 & 29,8 & 47,7 \\
\hline Clerks & 15,8 & 38,9 & 45,3 & 14,7 & 22,7 & 62,6 \\
\hline Sales workers & 17,9 & 40,5 & 41,6 & 15,5 & 20,7 & 63,8 \\
\hline $\begin{array}{l}\text { Service } \\
\text { workers }\end{array}$ & 15,2 & 49,7 & 35,1 & 11,1 & 25,8 & 63,0 \\
\hline $\begin{array}{l}\text { Modern } \\
\text { manufacturing } \\
\text { workers }\end{array}$ & 24,5 & 42,6 & 32,9 & 28,5 & 22,5 & 49,0 \\
\hline $\begin{array}{l}\text { Traditional } \\
\text { manufacturing } \\
\text { workers }\end{array}$ & 10,4 & 37,1 & 52,5 & 9,9 & 19,1 & 71,0 \\
\hline Drivers & 14,9 & 48,2 & 36,9 & 13,7 & 26,8 & 59,5 \\
\hline
\end{tabular}

${ }^{36}$ For instance, in 2009, one in every four of construction workers (codes 7151 to 7170 in PNAD) aged 30 to 34 years were either an offspring or other kind of housemate in a household headed by others.

37 At the age of 35 or older, no less than $86 \%$ of construction workers were either heads of families or their spouses, according to the same 2009 PNAD. 


\begin{tabular}{|l|c|c|c|c|c|c|}
\hline $\begin{array}{l}\text { Other manual } \\
\text { workers in } \\
\text { maintenance, } \\
\text { cleaning etc. }\end{array}$ & 14,4 & 50,6 & 35,0 & 14,2 & 27,9 & 57,9 \\
\hline Other & 19,2 & 56,3 & 24,5 & 14,8 & 35,4 & 49,8 \\
\hline Total & 17,9 & 45,5 & 36,6 & 16,2 & 25,1 & 58,8 \\
\hline
\end{tabular}

Source: Microdata, RAIS-MIGRA Vínculos

Modern manufacturing includes metallurgy, electricity, mechanics, urban utilities, forging and others; traditional includes textiles, food, garment, wood, leather etc.

\section{A 'new middle class'?}

These findings pose important structural limits to the arguments celebrating the emergence of a new middle class in Brazil $^{38}$. Self-employment and informal salaried positions are no synonym of freedom or autonomy from an employer, or indication of unconstrained working conditions. In 2009, 20\% of informal own-account workers worked 50 hours a week or more (compared to $11 \%$ of formal wage earners). Besides, men would have stayed for 153 months in this position in 2009, and their mean school years were only 5.6. For many, self-employment is a residual situation, not a position previously desired or purposively manufactured during the life cycle. By the same token, a good part of the informal salaried workers earn enough to qualify as part of the emergent 'middle class', but their grip in the economic structure is insecure and unstable, their jobs are lost at any signal of economic crisis and their next job will not necessarily match the previous standards. Most of all, considering the 1992-2009 period, $64 \%$ of them figured amongst the $40 \%$ lower stratum of the mean income's distribution (informal own-account rate was $52 \%$, compared to $26 \%$ of formal wage earners) ${ }^{39}$.

38 The most important proposition of this thesis can be found in Neri (2010).

39 All data computed directly from PNAD 1992-2009. 
If the economy does not offer sufficient conditions for stable and protected work, the mechanisms that produce and reproduce social and economic inequalities will persist. Besides, income is increasing for most of the occupied labour force, as Neri (2010) and others rightly argue, but this is happening in a labour market structure that is precarious and very unstable for young and also for mature workers of 35 years and older. Looking at the picture from a life cycle perspective, the challenges of the growing economy is not only to create good jobs for the new generations, but to assure quality social positions and income to the older ones, all this in a very unstable and precarious environment.

Because most self-employed and unregistered salaried workers are located in small commerce and services to persons and families, their income is directly dependent on the wealth produced elsewhere and appropriated by wage earners of all sorts, who will spend their money on the goods and services that informal workers deliver. The increase in the mass of salaries will certainly benefit them, and this may happen in a way that some of the self-employed workers may (and most probably will) become small employers and even formalize their business, thus registering their informal workers, paying taxes, demanding credit, in a word, helping move the economy while being moved by it. Economic growth may bring about the amelioration of the economic and social conditions of informal workers in a way that may actually help them depart from the realm of necessity. But the country is still far from this scenario.

\section{Younger and new generations}

In 1992, when the information was collected for the first time by the PNAD, 36\% of men and $30 \%$ of women claimed to have started working at the age of 10 years or less, and $80 \%$ of 
men and $68 \%$ of women began at 15 years or younger ${ }^{40}$. This is one of the various measures of the cost of the past that framed the working population profile at that juncture. And in fact, Ribeiro (2008) has shown that, in 1996, some 80\% of the Brazilians, considering parents and their offspring, had experienced a ruralurban migration, and in rural areas child work was a rule. The inertia of these figures is astounding: 22 years later (2014), we still found $21 \%$ of men and $15 \%$ of women claiming to have started working at the age of 10 or less. Two thirds of men had started at the age of 15 or less. If we consider 25 year old men or younger, 50\% had started working before completing 16 years in 2014 (compared to $36 \%$ of young women). This is proof that the beginning of working life is being postponed throughout time, but at a very slow pace. Even the youngest generations have started work very early. Most importantly, at the age of $18,51 \%$ of males and $52 \%$ of females had already left school in 2014 (compared to 62\% and 56\% in 1992), and these figures were not equally distributed across the social classes.

Early leaving from school has long-lasting consequences for a person's working life, but even today, incidence of the trade-off between school and work is skewed towards the latter, especially in poorer families. One half to two thirds of the wealthier families (those that earn double the minimum wage per capita or more) enrol their offspring in higher education, but the figure is no higher than $15 \%$ for families earning only the minimum wage per capita or less. Increasing numbers of men and women have been returning to school later in trying to catch up with labour market changes and the new demands for skilled workers in the emerging sectors ${ }^{41}$.

\footnotetext{
40 All figures in this section are computed from PNAD microdata.

${ }^{41}$ In recent years manufacturers and employers of all sorts complain that Brazil is in face of a shortage of skilled workers, which is presumably limiting the
} 
It should be noted that choosing work against school was a rational decision of poorer families in the stagnated Brazil of the 1980s and 90s. Access to quality universities was (and still is) a function of strong investment in early, private education, something difficult to achieve in poor households. And even if families decided to choose some kind of deprivation to favour part of their children, the prospects of a good job after schooling were never clear, due to the ups and downs of labour market opportunities in more than twenty years of meagre economic growth. The new generations are still paying the price of their parents' decisions, and many are making decisions as if the country were still sailing in the mist, with no clear future ahead ${ }^{42}$.

\section{Conclusion}

Work and employment relations outside the formal economy remain very high in Brazil. Most men and women start their working lives in an informal occupation, at early age, most often before completion of eleven years of schooling. Informal salaried and own account positions are entrance doors and also constitute a reserve army of labour for the formal labour market. When the latter expands rapidly, it feeds from this wellestablished repository. This means that, looking at the picture from the standpoint of the occupied labour force, the labour market at any one point is a snapshot of this formal/informal labour market interdependent mechanisms, which are mobilized in different moments of workers' employment careers according to a logic that combines individual (and family) strategies with

potential for economic growth. But most experts in the field contend that this is not the case. See Barbosa Filho et al. (2010), Maciante e Araújo (2011).

${ }^{42}$ According to the PNAD, only 25\% of the 20-24 year old Brazilians were studying in 2014. 
the actual structure of opportunities, a logic the element of which is, most often (but not always) the need to survive.

The problem is that for a large proportion of the working population, the informal portion of the labour market is not transitory, or a reception hall for those waiting for better positions. Rather, it is the dead end of their work histories. The country will not create good and protected jobs for the majority of these workers, either because they are not sufficiently skilled; or because of age discrimination in a labour market with oversupply, which allow firms to opt for younger workers willing to exchange school time for increasingly better paid jobs; or because of the physical deterioration of men and women as a result of the precarious work conditions they had to face in their working histories during stagnation; or because of the pattern of development the country seems to be pursuing, predominantly based on commodity exports, along with limited investment in high quality manufacturing, service and commerce sectors, the consequence of which is the continuous creation of bad quality jobs etc. ${ }^{43}$

In this scenario, the country has to face what I have called the 'cost of the past', a concept that denotes a set of economic and demographic dynamics that has punished generations of workers with low growth and precarious jobs, meaning unprotected and badly paid. The challenge is to find means to alleviate the future deprivation of these workers and, at the same time, create good jobs for the new generations. Economic

${ }^{43}$ In 1997 the economist Luciano Coutinho proposed the term 'regressive specialization' to characterize the economic restructuring in the 1990's. The concept referred to a process in which large scale producers of standardized goods, intensive in energy and natural resources and with low value added capacity, are favored by the overall economic environment, and expand more rapidly than the other sectors. David Kupfer, an expert in manufacturing restructuring, argues that the process is deepening in the 2000s. See Coutinho (1997) and Kupfer (2004) 
development along with productive inclusion may fulfil this task in the medium run. Young people of 29 years or under have appropriated some $30 \%$ of the new jobs created in recent years, and their unemployment rate is amongst the lowest in the world (around 11\% in 2010). However, their informality rates are still very high, and their salaries are still consistently lower than that of the older generations, despite their higher levels of education. In addition, $70 \%$ of the new jobs for men were occupied by 30 year old people or older, with previous labour market experience in informal positions. However, this exchange comprised a minor proportion of the occupied labour force, so that formality rate could only return to its 1981 level. It is true that formal salaried relations are expanding fast in Brazil, but the social debt accumulated in decades of precariousness is still very high.

In that respect, the response to the first challenge (safeguard the older generations) will fall on the shoulders of the State's redistributive capacity, and on its ability to recognize these 'lost generations' the right to a dignified life, in an environment inhospitable to the secure establishment and extension of this right. This environment is still moulded by precarious and unprotected mechanisms of making a living, and it is also framed by important macro-economic restrictions to redistributive policies.

Good quality labour markets are crucial. In a capitalist society the labour market is still the main way of access to social positions; to conditions that give way and sustain individual and collective identities; to income; and to an important social right: decent retirement. Labour markets respond to investment: public (demanding services and infrastructure, expanding public services etc.), private (especially in the case of labour intensive sectors) and of families (in their members' skills and quality of life). In the 10 years that ended in 2010 the rate of investment 
in Brazil has varied little around 17\% of the GDP (compared to $40 \%$ in China and $22 \%$ in many OECD countries), and the increase in workers' education and training has been very slow by international standard ${ }^{44}$. Better and more stable labour market conditions require higher rates of investment of all economic agents, and government of the three administration levels (federal, provincial and municipal) should face the challenge of leading the economy's investment drive and of offering much better education services.

It is true that the rate of investment in education has been increasing in recent years. After decades of underinvestment, in 2009 public expenditure per pupil in primary education was equivalent to $20 \%$ of the GDP per capita, a little below the USA and the high-income OECD countries ${ }^{45}$. The problem, of course, is that GDP per capita was under US\$10.000 in Brazil and over US $\$ 40.000$ in these areas. The equivalent proportions hide the relative poverty of available resources in Brazil. So the country must assure economic growth but also increase the proportion of GDP invested in primary and, most especially, secondary education $^{46}$. This is urgent, though the labour market consequences appear only in the medium and long run. It must also stimulate labour-intensive sectors in services and manufacturing.

Labour markets also respond to institutional settings and labour regulations. Most agents would agree that conformity

${ }^{44}$ Comparing to Korea in the 1970's and 80's, and to China and India in recent years, as well as to Chile and Argentina and Uruguay, Brazil stands far behind in mean school years of its population and also in the quality of education, measured by international comparative math and language exams.

45 In 1999 the rate was of 10\%, and much less than that in the 1980s. For a more recent period, see World Bank data in http://data.worldbank.org/indicator/ SE.XPD.PRIM.PC.ZS.

${ }^{46}$ Investment per pupil in secondary education was of $20 \%$ of GDP per capita in 2009, 25\% less than the expenditure of OECD countries. See World Bank data in http://data.worldbank.org/indicator/SE.XPD.SECO.PC.ZS. 
to labour law is hard to maintain in micro and small business. The labour movement and the left-wing Workers' Party (in office since 2003) have always resisted any attempt to reform the labour code for fear of deregulation and flexibility. But a concerted State led project, (incorporating capital, labour and policymakers) to reduce labour costs for small and micro business could extend the formal employment rate, labour productivity and even real wages, and stimulate better working conditions for men and women. 


\section{CHAPTER VI \\ LABOUR INSPECTION IN BRAZIL ${ }^{1}$}

Written with Telma Lage

\section{Introduction}

Over the past ten or fifteen years in Latin America, renewed attention has been paid to evaluating the impact of labour institutions on labour markets and on the economy as a whole ${ }^{2}$. One particular attitude has gained hegemony here, that is, recommending policies that invariably favour more flexible

1 Translated by Diane Rose Grosklaus, from DADOS - Revista de Ciências Sociais, Vol.48, No.3, pp. 451-489, July/Sept. 2005, for the Scielo Social Sciences (http:/ / socialsciences.scielo.org/scielo.php?script=sci_arttext\&pid=S0011$52582006000200004 \& \operatorname{lng}=\mathrm{en} \& \mathrm{nrm}=\mathrm{iso})$. I've revised the translation for this publication.

2 This study was part of an international comparative research project coordinated by Graciela Bensusán, of the Universidad Autónoma Metropolitana, Mexico, and funded by both Mexico's Consejo Nacional de Ciencia y Tecnología (CONACYT) and Brazil's Conselho Nacional de Desenvolvimento Científico e Tecnológico (CNPq). In addition to Graciela Bensusán, we would like to thank Hector Palomino, Cecília Senén, and Rodrigo Figueroa (the other members of the international team), as well as Michael Piore, Richard Locke, Maria Ester Feres, Mara Hernandez, and Judith Tendler for their comments. We would also like to thank other participants at an international seminar on labour inspection organized by Bensusán and Piore at the Massachusetts Institute of Technology in early 2005, where a preliminary version of this study was presented. Lastly, our thanks to the two anonymous peer reviewers from Dados for their observations, which made a decisive contribution to the final 
labour laws, with the idea of refuelling economic growth, boosting productivity and making Latin American countries more competitive and therefore better adapted to the demands of globalization. Yet experience has shown that such policies have achieved varied results, in numerous cases at some remove from their original objectives ${ }^{3}$. Moreover, similar changes across different contexts have quite often yielded diverse outcomes and brought unexpected consequences, for one thing because they failed to take account of the complex nature of labour market institutions. Policy makers have further overlooked the fact that these institutions cannot be analysed in isolation, ignoring their internal articulations, ambivalent roles, and the true extent to which labour laws are obeyed; after all, they are the product of a combination of historical and cultural factors not easily transferred from one country to another. These factors are almost never considered when uniform policies are recommended for different countries.

Because some of the problems derived from labour reforms have persisted, worsened, or triggered new ones ${ }^{4}$, more

version of the paper. Of course any errors are the sole responsibility of the authors.

3 A good critical review of the literature on the impact of labour legislation in OECD labour markets can be found in Bertola, Boeri, and Cazes (1999), who argue that available evidence falls short of supporting the idea that more flexible labour markets are more efficient or more equitable. An analysis of data from several Third World countries leads Squire and SuthiwartNarueput (1997) to the same conclusion. A fine study on how Brazil's 1988 Constitution and its new labour rights has failed to affect labour market dynamics can be found in Barros et al. (1999). For opposing arguments, see Marques and Pagés (1998), Scarpetta (1998), and Heckman and Pagés (2000).

4 We refer to the growing precariousness of jobs and the ensuing impact in terms of social integration; wage differences by age, gender, or ethnicity; the low living standards of groups that are highly vulnerable to unemployment, like young people; and increasing poverty among wage earners, all of which has been well documented in several research studies, such as Cardoso (2000), Cardoso Jr. (2000), Tokman and Martínez (1999), Egger (1999a, 1999b), Berry and Mendez (1999), and Guimarães (2004). 
complex assessments of the advantages and disadvantages of labour institutions are needed. How well do they achieve efficiency and equity in markets in general, in economic performance in particular, and, above all, in protecting workers in a climate where productive restructuring breeds inequality, unemployment, and precarious 'survival jobs'?

One of the questions neglected in the literature on how labour regulations impact labour market efficiency is just how effective the laws are. In other words, how do they actually perform when it comes to daily work relations 5 ? Though there are more sophisticated econometric studies that do take interactions between labour market-regulating institutions into account when explaining their dynamics - such as Belot and Ours (2001, 2004) - these studies still leave this key issue aside, namely, the extent of compliance and non-compliance with legislation. A given country's labour regulation system may be quite detailed and strict in formal terms yet prove very flexible in practice simply because employers can decide whether or not to abide by its precepts.

In 1947, the International Labour Organization (ILO) released Convention 81, regulating labour inspection in countries where labour relations have traditionally been regulated by law rather than contract (like Brazil, Argentina, and Mexico, for example). Ever since, the chances of getting caught and sanctioned for disobeying labour laws has depended first and foremost on the design of the national labour inspection and

5 An exception to this is Squire and Suthiwart-Narueput (1997). There has been a longstanding debate in Brazil about labour legislation's actual effectiveness in daily work relations although not from the angle mentioned, that is, labour market efficiency. A good overview of the discussion on the effectiveness of Brazil's labour code (Consolidação das Leis do Trabalbo) down through history can be found in French (2004). 
surveillance systems ${ }^{6}$. In the Brazilian case, the system comprises three main agents: 1) the government, through the Ministry of Labour (Ministério do Trabalho e Emprego), which exercises inspection power, and through the Public Labour Attorney (Ministério Público do Trabalho), which handles public civil suits in the defence of diffuse and collective interests; 2) labour unions and civil society organizations; and 3) the Labour Justice, which can hand down decisions ordering redress for the breach of labour rights.

This study examines the activities of the first of these agents (the government) and assesses inspection activities in terms of the efficiency of methods, efficacy in attaining intended goals, and effectiveness or scope. We are looking for the answer to a very direct question: Given that the effectiveness of labour legislation depends upon interactions between overall sanctions and the likelihood that an employer will be caught breaking the law and, further, given that the law's effectiveness is essential to obtaining a true measurement of a country's labour costs, to what extent has Brazil's labour inspection system been designed to meet its objective of enforcing the law? In answering this question, we look first at the opportunity structure available to entrepreneurs when they decide whether or not to abide by legislation. Sanctions for noncompliance are also analysed. We then present a brief historical overview of the Brazilian labour inspection system. In the third section, we offer a detailed description of the system that reveals the structure behind inspection activities and its prerogatives and powers. Focusing on the system's material results, the fourth section evaluates its efficacy, efficiency, and effectiveness. In a summary of findings, our conclusion shows that while the system has improved, it

6 When this chapter was written, Convention 81 had been ratified by 133 countries, Armenia being the latest on the list (December 2004). 
still does not fully satisfy what is perhaps its main goal: to curtail the rate of illegal labour relations in Brazil by expanding the number of companies and workers inscribed within the world of regulated work.

\section{The costs of obeying or disregarding labour laws}

Strictly from the perspective of company management, whether or not to abide by the labour legislation is a rational, cost-benefit decision made by the individual entrepreneur. If the employer feels labour costs are very high, he may decide to run the risk of not paying them. This decision takes into account an integrated set of constraints. The risk is of course a direct function both of the employer's likelihood of being caught and of the applicable sanction - that is, the economic and sometimes personal costs. The simplified opportunity structure is presented in the chart below. The rows express an employer's risk of being caught breaking the law and of a sanction actually being imposed (high or low risk). Taking into account the costs of noncompliance, the columns reflect the relative overall weight of the penalty that will be imposed (likewise high or low).

Figure 1. Opportunity Structure for Compliance with Labour Legislation

\begin{tabular}{|l|c|c|c|}
\cline { 3 - 4 } \multicolumn{2}{c|}{} & \multicolumn{2}{c|}{ Relative Overall Weight of Sanction } \\
\cline { 3 - 4 } \multicolumn{2}{c|}{} & High & Low \\
\hline $\begin{array}{l}\text { Risk of being } \\
\text { caught and } \\
\text { suffering sanction }\end{array}$ & High & 1. Obey & 3. Disregard \\
\cline { 2 - 4 } & Low & 2. Disregard & 4. Disregard \\
\hline
\end{tabular}

The combination of these possibilities produces four typical responses: 1) the employer obeys the law, because he feels the sanction is heavy enough to warrant avoiding it, and 
the risk of getting caught and punished is also high enough to be credible (let's say, substantially greater than $50 \%$ );2) the employer does not obey the law because the sanction for disregarding it is high but the chances of getting caught are nevertheless quite low (for instance, well under 50\%); 3) the employer opts not to obey the law, because the risk of getting caught is high but he deems the sanction so small that it is more rational to pay it than labour costs; 4) lastly, the employer will once again ignore the law, because both the sanction and the risk of getting caught are low. Please note that labour costs are implied in the amount of the sanction. Likewise from the perspective of business management, the weight of a sanction can be high or low compared to the monetary costs of abiding by the law. So the opportunity structure described above only makes sense when labour costs are deemed high enough vis-àvis a firm's cash flow spreadsheet and projected profits, within a competitive market situation where other businesses face the same opportunity structure.

This schematic chart is helpful above all because it shows that the dominant strategy is noncompliance with legislation. Faced with high enough labour costs, rational entrepreneurs will tend to avoid paying these unless sanctions outweigh them and the likelihood of getting caught and sanctioned is credible enough. Any other combination of factors will encourage noncompliance. Thus, the decisive variable is the effect of the interaction between the cost of disobedience and the likelihood of being caught and punished. The literature on the relation between labour costs and labour market dynamics neglects this key aspect of entrepreneurial strategies, to wit, the effectiveness of the law as derived from an opportunity structure where the likelihood of getting caught is decisive.

What is the cost of breaking labour laws in Brazil? The country's network of legal protection for workers encompasses a 
variety of complementary mechanisms that can be set in motion at different moments during the employment relationship. A first level of control lies in the employer/employee relationship per se. In this instance, the employee himself is the 'inspection agent', who can call the employer on his noncompliance (tardiness, postponement, or withholding of payments due). Almost always related to the dismissal of the worker, these payments usually must be made at the time the labour claim is petitioned at the Labour Justice. Examples include double pay for vacation not granted in timely fashion; double time pay for work on days of rest; time and a half pay during allotted breaks; $50 \%$ over the value of undisputable payments (verbas incontroversas) ${ }^{7}$ when these are not paid at the first hearing of a labour suit; and a fine equivalent to one month's wage for late payment of mandated severance pay (verbas rescisórias).

We next analyse institutional inspection, which comes under the responsibility of the Ministry of Labour, which is the agency empowered to find facts, issue Notices of Infraction, and impose fines on companies in breach of the law. In the section that defines the rights and duties of employees and employers, the Brazilian labour code, the CLT, lays out the penalties applicable in cases of noncompliance. Inspection activities fall within the realm of administrative law and are thus part of public law. The specific amount to be charged is established per worker and then multiplied by the number of irregularly employed staff; the amount goes up if the problem recurs. Chart 2 presents fines imposed for selected aspects of contract relations.

Examples of indisputable payments include wages, the year-end bonus known as the ' $13^{\circ}$ salário', vacation pay, and FGTS, in the case of formalized employment relationships; examples of disputable payments include: overtime, hazard pay, pay for working under unhealthy conditions, isonomia salarial (equal pay for equal tasks), and other cases in which a labour suit requires that the worker prove his allegations. 
Let us take the workday as an example. A company with up to ten employees that fails to enforce the eight-hour day will be fined BRL 2,700, whether one or more of its employees is affected. If the firm is also in contempt of overtime laws, it will receive another fine in the same amount, and so on. In the case of repeat offenders, fines are doubled. Some activities are classified as criminal violations. This is the case of misrepresentation for example, when an employee provides false information or an employer makes a fraudulent annotation on the employee's workbook (Carteira de Trabalho) ${ }^{8}$. In legal and union circles, it is commonly accepted that fines are in principle reasonable and high enough to curtail breaches of the law, especially in small and medium enterprises. As stated earlier, the issue is determining how likely it is that the employer will get caught if he decides to ignore the law.

Figure 2. Labour Fines for Selected Infractions

\begin{tabular}{|l|l|}
\hline Type of infraction & Fine \\
\hline $\begin{array}{l}\text { Length of workday (maximum hours } \\
\text { per day, maximum hours per week, } \\
\text { 6-hour night shift, overtime, etc.) }\end{array}$ & $\begin{array}{l}\text { BRL 2,700 to 4,000 per incident, } \\
\text { depending on size of firm }\end{array}$ \\
\hline Illegal temporary contracts & BRL 402 per employee \\
\hline
\end{tabular}

Source: DRT (Regional Labour Office) - Rio de Janeiro.

Sanctions for non-observance of labour legislation can originate from several sources, not just the government. Under new production management models, for instance, in which the quality of the final product depends upon coordinating several firms in a productive value chain, contractors can demand that

8 Articles 197-203 of Brazil's Penal Code spell out 'crimes against labour organization.' These have little bearing on the present study, given that the 'Special Part of the Penal Code is a mirror image of Italy's Rocco Code, of recognized fascist inspiration,' according to Nogueira (2000). 
any of their subcontractors abide by quality standards like ISOs, which contain stipulations about decent working conditions and, sometimes, remuneration'. Similarly, businesses operating on the international markets have an interest in obtaining quality certification, which may have a positive impact on working conditions. International market standards also encourage firms to abide by the law. Governments have banned products from countries that use child or slave labour. They have accused countries that pay their work force poorly of 'social dumping'. They have demanded declarations of adherence to labour legislation before allowing companies to take part in public tenders. More and more distributors (supermarkets) are adopting fair trade standards with Third World countries, imposing nontariff barriers by granting favoured-nation status to countries that follow international norms. In some countries, like Brazil, large firms are required by law to have occupational safety and health systems in place, along with accident prevention committees. Unions can also play a decisive role in increasing the costs of noncompliance. When the collective interests of workers are disrespected, Brazil's Public Labour Attorney has the power to conduct administrative inquiries and sign 'termos de ajuste de conduta' ('Terms of Behaviour Adjustment - TAC), which are legally binding contracts between signatories. These incentives, however, are almost always aimed at market niches and hard

\footnotetext{
9 It is true that the opposite is often the case and actually typical of certain production chains, such as chemicals (Mello e Silva and Rizek, 1997), textiles (Costa, 2006), civil construction, and the manufacture of large home appliances like stoves and refrigerators (Gitahy, 1997). In the automotive industry, because of the serious accidents caused by poor quality control at subcontracted companies, the transfer of technological and quality standards has helped to improve labour relations on the far edges of the productive chain (Carvalho, 2001; Marx, Salerno, and Zilbovicius, 2003); however, this still has not been enough to force these subcontractors to abide by the law. Recent research has actually shown that precarious, illegal and informal work are typical of various subcontracted value chains (Jacob Lima, 2007; Telles, 2010).
} 
to put in place throughout the economy. They usually apply to large companies, where unions have a firm footing and the company's products and services are sold on the international market. In practice, the main agent of labour inspection in Brazil is the Ministry of Labour, through its Regional Labour Offices, which we analyse in the next section.

\section{A brief historical overview}

Just like the Ministry of Labour, Brazil's surveillance and labour inspection system went through several phases throughout its history. Its origin dates to 1930, when the Getúlio Vargas administration created the Ministry of Labour, Industry, and Commerce. Even the Vargas era cannot be seen as a single phase, since all the machinery for inspecting and suppressing illegal labour and for encouraging company compliance was added only bit by bit, as new regulations were gradually created or old ones modified.

The literature reflects something of a consensus. It shows, in the first place, how businesses resisted the adoption of labour legislation gradually put in place by the Vargas administration ${ }^{10}$. Secondly, it suggests that although entrepreneurs were always resistant, they eventually adhered to regulations, in part because this suited capitalist accumulation (Oliveira, 1972) and in part in response to the governments in power between 1950 and 1964 (including the Vargas administration), which were more open to union demands.

The system of incentives for encouraging the formalization of labour relations was almost always limited to the imposition of fines to punish disobedience, that had been reported by

${ }_{10}$ Among others, see Werneck Vianna (1999), Tavares de Almeida (1978), Gomes (1988), Rodrigues (1968), Moraes Filho (1979), and French (2004). 
workers or, more often, discovered during unannounced visits by Ministry of Labour inspectors. Under the Vargas dictatorship, however, employers were offered positive nonmonetary incentives if they agreed to the corporatist order and the regulation of the labour market. This meant, for instance, taking part in bipartite mechanisms to design industrial policies, access to public financing, and favoured status in public tenders (Diniz and Boschi, 1976) ${ }^{11}$.

As was discussed earlier in this book, the system of labour market regulations has survived Vargas. In activities demanding formal labour - that is, urban industrial employment - it is likely that the rate of formalized labour relations was already quite high in the 1950s, perhaps around 45\% (Lobo, 2010). The ILO's Convention 81, which addresses labour inspection in manufacturing and commerce, was enacted by Legislative Decree in 1956 and promulgated in June 1957 by President Juscelino Kubitschek under Decree no. 41,721. Yet the first systematic regulation of this activity dates to 1965, when Presidential Decree no. 55,841 instituted the Labour Inspection Rules (Regulamento de Inspeção do Trabalbo) ${ }^{12}$. It is not clear why the new military government decided to conform to the ILO Convention 81, for in 1971, the Garrastazu Médici government denounced the Convention under Presidential Decree no. 68,796, which was revoked only in November 1987.

${ }^{11}$ Down through Brazil's history, the inefficiency of its inspection system has been criticized countless times. In his analysis, French (2004) cites the small contingent of labour inspectors, their corruption, unequipped Regional Labour Offices, and the negative impact of inflation on the value of fines, to name just a few of the system's shortcomings. According to some authors, the same problems hold true even today (e.g., Cappellin, 2005).

${ }^{12}$ Until then, labour inspection was regulated solely by the CLT and by normative instructions and decrees handed down by the Ministry of Labour and Social Security (Ministério do Trabalho e Previdência Social). 
The democratization of the 1980s made room for social agents to question inspection mechanisms. Law 7,347 (1985) authorized the Public Attorney (Ministerrio Público), along with other public and civil bodies, to process public civil petitions (açoes civis públicas), which are a kind of class action suit to protect subjective, collective and diffuse rights. Brazil's 1988 Constitution strengthened the Public Attorney's role in this arena, in theory affording workers' representatives a more efficacious way of intervening on behalf of their rights. Through a behavioural adjustment term (TAC), public and private agents agree to suspend charges in exchange for a commitment to correct the irregularities in a bargained timeframe. If this commitment is not met, the process by which the imposed fines are actually collected is accelerated, since the TAC is an enforceable binding contract. The efficacy of this mechanism has yet to be assessed ${ }^{13}$; for now, we have based our work on the fact that inspections have relied on fines as a means of pressure. However, sharply rising post-1979 inflation quickly eroded the real value of the fines stipulated in the CLT, the deflation of which has always depended on the changing political moods and legislative bargains in the National Congress.

In the 1990s, labour inspection moved back onto centre stage. The primary innovation was an attempt to make bargaining the main path to settling issues arising out of labour inspections. In July 1999, the Ministry of Labour handed down a Normative Instruction (revised in 2001), which requires Conciliation Tables (Mesas de Entendimento) to be held whenever labour inspections do not lead to immediate redress by an employer. These Tables must be led by inspection heads or by inspection auditors themselves, when delegated this power by inspection heads.

${ }^{13}$ A recent, very well documented study on the matter is Filgueiras (2012). He shows that firms can evade compliance to the TACs in many ways, including fraud, violence against inspectors, bribe and others. 
Auditors may summon other auditors to their Tables and may also convoke the unions or employers' associations that represent the agents involved (although they are not required to do so). The establishment of a Conciliation Table must be reported to the Regional Labour Delegate. The Normative Instruction determines how long the Tables should remain in effect and defines other relevant procedures, but it allows inspection auditors freedom in conducting the work itself as long as the Regional Labour Delegate is kept informed. Although it has not yet been determined how these Tables may impact the system's efficacy, aggregate statistics on labour inspection have not changed much in recent years, except for those regarding the FGTS (Fundo de Garantia por Tempo de Serviço) deposits ${ }^{14}$.

\section{How the system is designed}

The current structure of Brazil's Ministry of Labour is depicted in the organizational chart below, which shows how labour inspection fits into the Ministry's overall activities. The Office of Labour Inspection (Secretaria de Inspeção do Trabalho, or SIT) is one of four executive offices subordinated directly to the minister's office, making it part of the second echelon of federal government bureaucracy; its head is appointed directly by the minister. This office enjoys great prestige and is politically strategic, since it has branches throughout the country in the form of Regional Labour Delegacies (Delegacias Regionais do Trabalho, or DRTs). There is one DRT in the Federal District and one in each state (27 in all), divided into

\footnotetext{
${ }^{14}$ As already noted, firms must deposit $8 \%$ of the monthly salary of each individual worker in a bank account in the worker's name. The worker is entitled to the accumulated fund and to a fine of $40 \%$ of it when dismissed without a 'just cause'. The global FGTS fund is administered by a tripartite body coordinated by the Ministry of Labour.
} 
114 branch offices throughout the country; these in turn have 480 service agencies. Answering directly to the minister's office, the DRTs are responsible for enforcing policies designed by the Office of Labour Inspection.

Figure 3. Structure of the Ministry of Labour - 2004

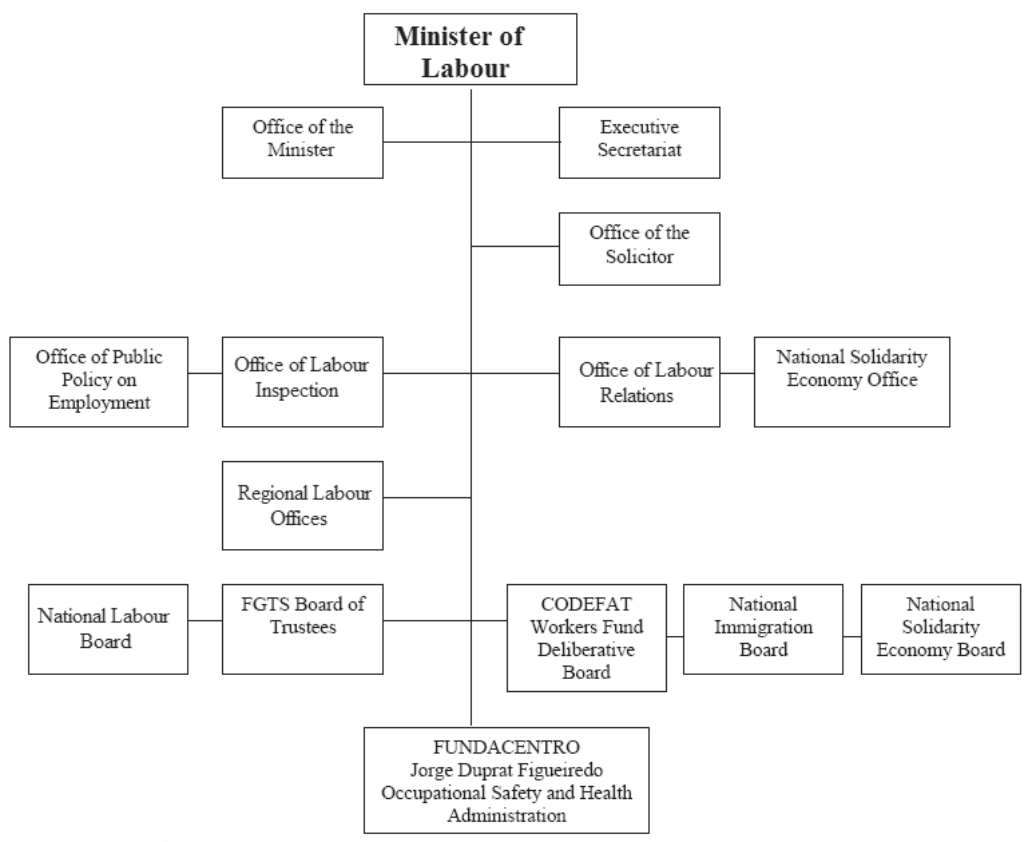

Source: www.mte.gov.br

Table 13 shows the evolution of spending by the Ministry of Labour in recent years, along with its participation in the Total Federal Budget (Orçamento Geral da União) and in the overall 
ministerial budget in particular ${ }^{15}$. The Ministry receives a very small slice of the federal budget as a whole, which reached a top figure of $0.33 \%$ in 2003 (although data for this year have not been wholly finalized). Data also suggest a rise in the Ministry's share of the budget after 1998, the year in which its percent of total budget spending fell to an all-time low $(0.14 \%)$. Its share of the general ministerial budget is also quite low in relative terms, having hit a maximum of $1.16 \%$ in 2003 , or $7 \%$ if we include the Workers Fund (Fundo de Amparo ao Trabalhador, or FAT). Note that when the FAT is included, the Ministry's consolidated budget has risen in relative terms, climbing from $5.8 \%$ to $7 \%$ in nine years.

Table 13. Ministry of Labour Investment Budget and its Share of the Overall Federal Budget and of the Ministerial Budget: 1995-2003

\begin{tabular}{|l|c|c|c|c|c|}
\hline Year & $\begin{array}{c}\text { Labour } \\
\text { Ministry }\end{array}$ & $\begin{array}{c}\text { Occupational } \\
\text { Safety and } \\
\text { Health } \\
\text { Administration }\end{array}$ & FAT $^{*}$ & Total & $\begin{array}{c}\text { Deflator } \\
\text { (mean } \\
\text { annual } \\
\text { Consumer } \\
\text { Price } \\
\text { Index) }\end{array}$ \\
\hline 1995 & $1,099,553,228$ & $32,737,644$ & $9,015,851,714$ & $10,148,142,586$ & 0.57328 \\
1998 & $1,105,748,457$ & $76,690,048$ & $11,859,096,374$ & $13,041,534,880$ & 0.63063 \\
2001 & $1,625,494,079$ & $61,776,345$ & $13,427,465,653$ & $15,114,736,078$ & 0.75494 \\
$2003^{(* *)}$ & $2,878,648,569$ & $38,693,798$ & $14,631,865,113$ & $17,549,207,480$ & 0.97304 \\
\hline
\end{tabular}

${ }^{15}$ The data in this table reflect the actual budget expenditures for each year, corrected for total average annual inflation (deflator based on the National Consumer Price Index). Expenditures had been closed through September 2003 at the time these data were collected from the Chamber of Deputies web site. 


\begin{tabular}{|c|c|c|c|c|c|}
\hline $\begin{array}{c}\text { Share of } \\
\text { General } \\
\text { Federal } \\
\text { Budget } \\
(\%)\end{array}$ & $\begin{array}{c}\text { Labour } \\
\text { Ministry }\end{array}$ & $\begin{array}{c}\text { Occupational } \\
\text { Safety and } \\
\text { Health } \\
\text { Administration }\end{array}$ & FAT $\left.^{*}\right)$ & Total & \\
\hline $\begin{array}{c}1995 \\
1998\end{array}$ & 0.26 & 0.01 & 2.16 & 2.43 & 1.64 \\
2001 & 0.21 & 0.01 & 1.50 & 1.97 & \\
2003 & 0.33 & 0.00 & 1.75 & 2.02 & \\
\hline $\begin{array}{c}\text { Share of } \\
\text { ministerial } \\
\text { budget } \\
(\%)\end{array}$ & Labour & $\begin{array}{c}\text { Occupational } \\
\text { Safety and } \\
\text { Health }\end{array}$ & FAT $\left.{ }^{*}\right)$ & Total & \\
\hline 1995 & 0.63 & 0.02 & 5.18 & 5.83 & \\
1998 & 0.50 & 0.03 & 5.37 & 5.90 & \\
2001 & 0.65 & 0.02 & 5.37 & 6.04 & \\
2003 & 1.16 & 0.02 & 5.90 & 7.08 & \\
\hline
\end{tabular}

${ }^{(*)}$ Fundo de Amparo ao Trabalhador (Workers Fund).

${ }^{(* *)}$ Consolidated data through September 2003.

Source: Based on General Federal Budget microdata available at http://www. camara.gov.br/internet/orcament/Principal/exibe.asp?idePai=2\&cadeia=0@

When analysing these data, we must remember that social security is part of the overall federal budget and ministerial budget, in itself accounting for nearly half of the total ministerial budget and almost $14 \%$ of the federal budget. Excluding social security, the Ministry of Labour received around 14\% of the ministerial budget in 2003 and ranked fourth in the general budget, behind the ministries of Social Security, Health, and Defence but ahead of the Ministry of Education (the two have traded ranks several times in recent years $)^{16}$. Something else that should be kept in mind is that

${ }^{16}$ The Ministry of Labour's increased participation in the 2003 General Federal Budget was a bit artificial because of Supplementary Law No. 110 (2001), 
while the FAT is managed by a broad board of trustees that comprise members of other ministries as well as representatives of capital and labour, most of its policies are designed directly by the Ministry of Labour. The most important of these include the national policy on labour training, one of the flagships of the Fernando Henrique Cardoso administration's employment policy, along with unemployment compensation, which consumes the lion's share of FAT funds (Lemos, 2003).

If we do an itemized analysis of the Ministry of Labour's 2003 budget $^{17}$, we see that $38 \%$ of funds were spent on personnel (both active and inactive). Expenditures on core activities, that is, investments themselves were less than $2 \%$ of the total. Of course, personnel payments constitute a significant portion of core activities, such as labour inspection, which encompasses the work inspectors do at companies. Furthermore, about $32 \%$ of layouts on core activities went to the Office of Labour Inspection in 2003. In 1995, the figure had been $22 \%$. In other words, over an eight-year period, between one-fourth to one-third of investment outlays were aimed directly at inspection activities. Labour inspection thus occupies a special place in the Ministry of Labour's organizational chart and its expenditures.

Brazil's 1988 Constitution states that the federal government is responsible for organizing, maintaining, and conducting labour inspection activities. The current Labour Inspection Regulations are set out in Decree 4,552, from December 2002, which regulated Law 10,593 that same month and year. These recent standards reiterate Brazil's formal

which mandated that the government indemnify holders of FGTS accounts for losses incurred due to earlier economic plans. These monies (BRL 1.7 billion) were sourced from the Workers Fund (FAT).

17 These data were taken from the federal budget, accessible at: http://www. camara.gov.br/internet/orcament/principal. 
commitment to labour inspection, pursuant to ILO Convention 81. The new Labour Inspection Regulations introduced the term 'labour inspection auditor' to replace 'labour inspector' as the name for the inspection agent. A key novelty of these regulations is that they broaden auditor autonomy by subordinating them directly to the federal authority ${ }^{18}$. Lastly, the CLT includes specific labour inspection standards that are still in full force, including the value of fines applicable in the case of irregularities.

In other words, even though NGOs, unions, and organizations from civil society can lodge denunciations (Dal Rosso, 1997), labour inspection is a government activity subordinated to the Ministry of Labour through its Office of Labour Inspection, as defined under law. The Office is divided into two departments: (i) Department of Labour Inspection, charged with planning and standardizing inspection activities, pursuant to labour legislation; (ii) Department of Occupational Safety and Health, which coordinates and defines parameters for inspections into the observance of occupational safety and health standards.

In accordance with ILO standards, the object of inspection is to promote compliance with legislation. The inspection auditor is entrusted with policing power that authorizes him 'to issue notifications; issue construction embargos; close establishments, service sectors, machinery, or equipment; and, if necessary, issue Notices of Infraction, which is the first instrument, prior to levying administrative fines' (Silva, 2002). The inspection auditor proposes such measures to the regional delegate, who

$\overline{{ }^{18} \text { Decree 4,552/02 }}$ - Art. 3: 'Labour inspection auditors are technically subordinate to the appropriate national authority in matters of labour inspection.' 
makes a decision and, if appropriate, determines the deadline for compliance ${ }^{19}$.

Inspections are conducted throughout Brazil, in all urban or rural private companies as well as at government-owned companies with employees on their payrolls ${ }^{20}$. In theory, offices of liberal professionals, philanthropic institutions, recreational associations, and other not-for-profit institutions with staff on payroll are subject to inspection, including households employing domestics. But as discussed below, this is not viable.

Auditors work within the geographic area covered by the service agency, branch office, or office to which they are assigned. They are given orders as to what firms should be inspected, but they may also undertake inspections at their own initiative. Inspection auditors are assigned to cover various areas within their district ${ }^{21}$ on a rotating basis, with the caveat that they cannot visit the same area during two consecutive periods. A candidate for the position of inspection auditor must pass a civil service exam, which is open to individuals holding a college degree. If the candidate wishes to work in occupational safety or health, he or she must have completed some level of graduate

${ }^{19}$ CLT - Decree law 5,452/43: Art. 161: 'The Regional Labour Delegate, in view of a technical affidavit from the competent service demonstrating serious, imminent risk to the worker, may close an establishment, service sector, machinery, or equipment, or issue a construction embargo, indicating in his decision, made in timely fashion as demanded by the incident, the measures that shall be adopted in order to prevent labour mishaps.'

${ }^{20}$ When the employer is a government agency (i.e., the federal, state, or municipal government, 'autarky, or public foundation), the inspection auditor is responsible if there are employees on staff - in other words, when there is a labour contract governed by the same legislation that governs the work covered in private contracts. Part government-part private companies and state-owned companies are subject to the private labour hiring regime and therefore to inspection.

${ }^{21}$ Labour Inspection Rules - Decree 4,552/02 - Art. 4: 'For the purposes of inspection, the territory within each federative unit shall be divided into districts, and corresponding headquarters assigned.' Regional Labour Offices (one per state) coincide with the districts mentioned in the article. 
studies at an accredited institution, in addition to passing the exam. The Regional Labour Delegate is a political appointee and not necessarily a career inspection auditor. Delegates are responsible for imposing fines, based on the Notices of Infraction issued by inspection auditors ${ }^{22}$.

Auditors are hired under the statutory Regime Juridico Unico, which means their wages are defined under law and job stability is guaranteed. According to Ministry of Labour data, an inspection auditor who is just starting his career may earn as much as USD 2,490 a month, while the figure is USD 3,289 at the highest level in the job hierarchy ${ }^{23}$. These are approximate figures, since the amount actually received each month depends on individual performance as well as on the performance of the system as a whole. There are two bonuses on top of the regular wage: Fiscal Activity Bonus (Gratificação de Atividade Tributária, or GAT), equal to $30 \%$ of the auditor's base salary, or $25 \%$ of the highest base salary; and the Bonus for Increased Inspection and Collection (Gratificação de Incremento da Fiscalização $e$ da Arrecadação, or GIFA), equal to $45 \%$ of the highest base salary for each position. One-third of the GIFA bonus reflects the auditor's individual performance while two-thirds reflects overall system performance. The federal government's four-year administration plans define the collection goals upon which the bonuses are based. This wage structure has a decisive impact on the efficacy and effectiveness of inspection, as we will see later.

In theory, a labour inspection is triggered by one of two complementary events: a denunciation is lodged or an address

\footnotetext{
${ }^{22}$ Imposing fines is a non-discretionary act (ato vinculado), i.e., the delegate has the power and duty to impose a fine but does not have autonomy to block the course of the administrative process that is automatically opened by the filing of a Notice of Infraction. However, the Ministry of Labour has the power to withdraw the process from lower administrative domains in order to examine it and make a decision.

${ }^{23}$ Data from the Ministry of Labour (2004:5), in dollars of July 2004.
} 
is randomly drawn. Since Regional Labour Offices do not have many auditors, inspections are in fact determined primarily by denunciations, which are numerous enough to keep the inspection agenda full ${ }^{24}$. According to one inspection auditor we interviewed ${ }^{25}$ :

'Right now, the vast majority of inspections are the result of complaints. The main denouncers are individual workers, but priority is usually given to complaints by unions, the Public Attorney, and the police (in the case of work accidents). Although the vast majority of inspection activities are prompted by denunciations, it's impossible to respond to them all; we don't have enough staff. That's why, among complaints made by individuals, we also usually place priority on those who identify themselves. Where possible, we can also organize a program to respond collectively to denunciations about the same company or productive sector' (interview conducted in August 2004).

If the inspection prompts the issue of a Notice of Infraction, an administrative process is triggered. When cited, the employer has ten days to present his defence. At the end of this time, an inspection auditor other than the one who filed the citation will examine the case, which consists of both the citation and the defence, or just the citation if the employer

${ }^{24}$ A document from the Ministry of Labour itself reads (2004:7): 'The greatest source of information that, in compliance with the priorities laid out in planning, will guide inspection activities are the denunciations filed by labour unions, the Public Labour Attouney, other governmental and nongovernmental bodies, and workers themselves, who turn to Inspection Auditors from the Regional Labour Office daily.'

${ }^{25}$ In this section, we have relied on interviews with six inspection auditors from Rio de Janeiro, one from São Carlos (rural São Paulo state), and one deputy delegate from each state. 
has not presented a defence. An official evaluation is compiled, which judges the charges as having whole, partial, or no legal merit. These documents are referred to the delegate or deputy delegate, who rules on them. If deemed without merit at this first level, the Notice of Infraction must be referred for analysis at a second level; if the case is again determined to lack legal grounds, it is dismissed. If it is found to have whole or partial merit, and the employer pays his fine within ten days after receipt of notification, he will receive a 50\% discount over the stipulated amount. If the employer does not agree with the fine, he has ten days to appeal at the second level, but he must still deposit the whole amount in order for his appeal to be examined. If the fine is approved at the second level, this deposit becomes the payment; if the employer's appeal is ratified, money on deposit will be returned. If the employer neither pays the fine nor appeals the amount in question, the debt is recorded as collectible by the federal government, a task that will fall to the Office of the Attorney General of the National Treasury, through the Federal Justice. The entire administrative process should last sixty days at most, according to a 2002 decision under Brazil's Labour Inspection Regulations.

According to the inspection auditors we interviewed, only small and medium size businesses generally pay their fines when a case is initially raised, which is a way of taking advantage of the $50 \%$ discount. Companies with in-house counsel usually appeal decisions. Appeals are first addressed at the administrative level. Once all appeals have run their course and the employer has refused to make payment, collection is handed over to the Office of the Attorney General of the National Treasury. It should be noted that this office is involved in collecting debts of a much greater amount than those in question here. According to Regional Labour Office staff, this means there is not much incentive to collect the fines and odds are high that the debt 
will be allowed to lapse. It is also worth remembering that once the administrative case has reached its end, the employer can appeal to the courts, where the whole process can be drawn out interminably.

The system is thus designed in accordance with ILO recommendations that mechanisms be in place to guarantee inspectors technical independence and create conditions in which they can fulfil their duties. Shortcomings in the enforcement of penalties notwithstanding, Brazil is much better equipped than some of its Latin American neighbours, such as Argentina and Mexico. In Mexico, inspection has two jurisdictions, one national and the other within the Federal District; the ensuing disputes over who has authority undermines the system's efficiency and efficacy. Even for higher-level staff such as physicians and engineers, salaries top out at USD 750 for those working within the national jurisdiction and at USD 550 in the Federal District. There are only three computers for the inspectors, who also are not provided with vehicles for traveling to work sites. Furthermore, there are very few inspectors and the number has been falling sharply in recent years. While there were 388 within the federal jurisdiction in 1994, the figure dropped to 181 in $2004^{26}$. In Argentina, inspectors are not required to have a college education; on average, they have completed 11 years of schooling (i.e., high school). Moreover, there is no career track within the civil service system and not all of the agents are protected by contracts offering job stability, contrary to ILO recommendations (Palomino and Senén, 2005).

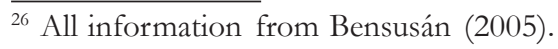




\section{Inspection outcomes}

Table 14 presents consolidated data on labour inspection in Brazil. The first point worth highlighting is the steep drop in the quantity of auditors between 1990 and 1995, a period when there were fewest inspectors, that is, a little under 2,000. In 1996, the addition of 800 new inspectors pushed the figure up substantially, but it has been trending downward since. The second point worth noting is that variations in the contingent of inspectors do not seem to have any relation to the number of companies visited or workers reached. On the contrary, the year in which auditors numbered fewest (1995) was also the year in which the most companies were inspected, that is, over 420,000, with an average of 215 businesses per auditor. If we were to rely on these data (an issue we will discuss shortly), everything would actually indicate that the system became more efficient when there were fewer inspectors. This leads us to our third observation: inspections have gained a new look in recent years, reaching more workers at fewer companies, which means the average size of visited companies has grown, starting roughly in 1997. Fewer businesses being visited by fewer inspectors but encompassing more workers every year translates precisely into greater inspection efficiency, along with greater effectiveness, since more workers are reached. 


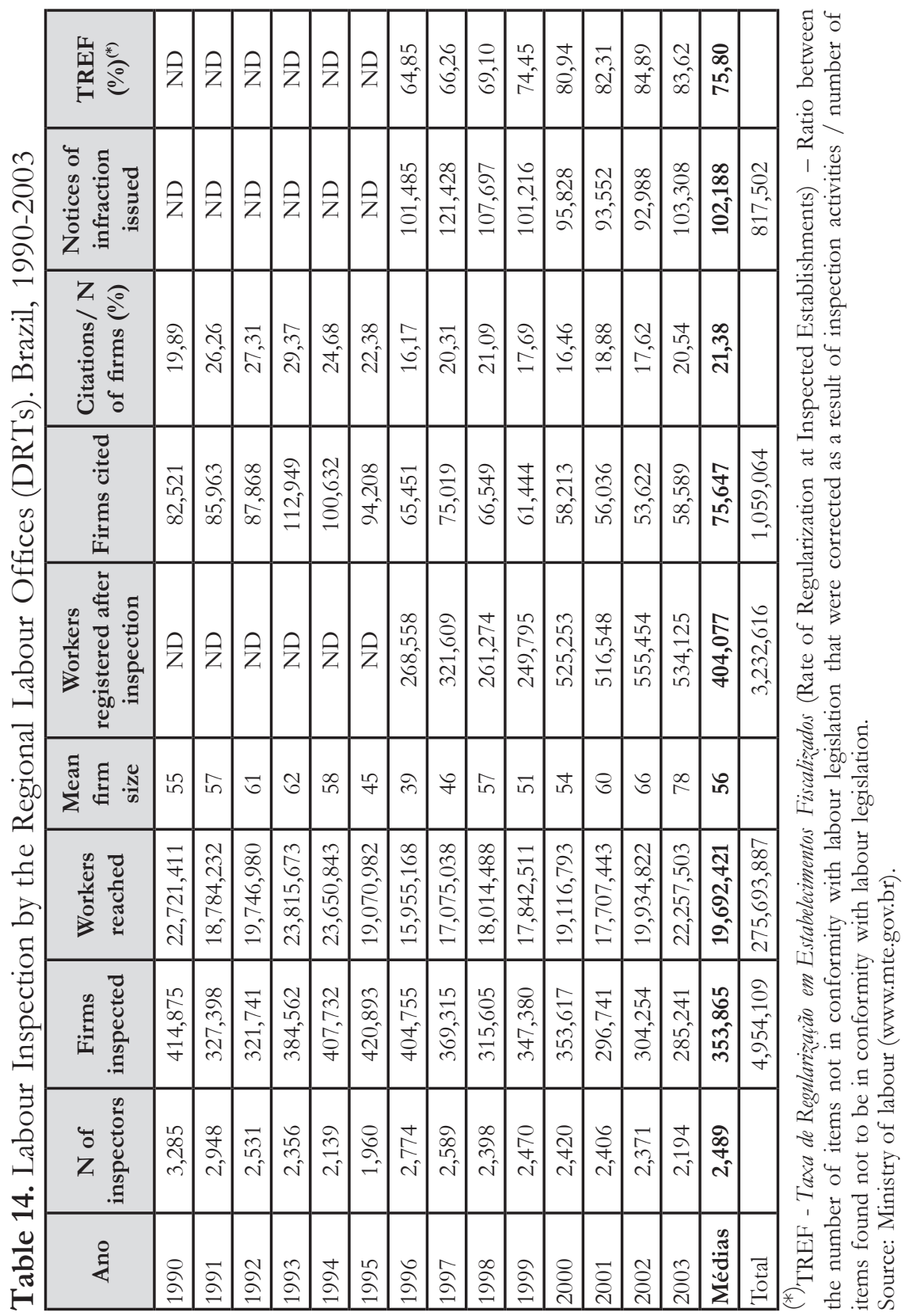


A fourth significant point has to do with the efficacy of inspection activities, which is reflected in the number of Notices of Infraction, the number of workers registered as a result of an inspection, and the rate of company compliance with labour legislation. Once again, if available data are to be taken as reliable, between $16 \%$ and $30 \%$ of the companies visited were cited each year, which means that no fewer than 250,000 workers were registered a year as a consequence of inspection activities - that is, their employment relationships were formalized as of 1996 (in regard to this particular item, no data are available for prior years). Although not discernible from the table, 2001 was the year when inspection encompassed the highest rate of workers $(2.92 \%)$, with an average of $1.17 \%$ for the period. The regularization rate - that is, the proportion of irregularities corrected following each inspection activity - has also risen significantly over these years, from 65\% in 1996 to 84\% in 2003. In short, these data would lead us to believe that the system seems headed towards a more streamlined, efficacious design when it comes to the regularization of labour relations.

Table 2 needs to be read with caution, however. The system's apparent efficiency is belied by the paradoxical circumstance that only $1.17 \%$ of employment relationships were corrected through inspection activities, whereas $21 \%$ of visited companies were cited during the period in question (1990-2003). While the citation rate is very high ( $1 / 5$ of all firms), the rate for regularizing employment relationships is very low $(1.17 \%$ of the workers reached). This may be due to one of three things. First, it may be that not all workers at a given enterprise are employed irregularly, so that even if many workers are encompassed, only some will need to have their situations regularized. Second, it may be that irregular situations and citations occur mainly in smaller companies, which means fewer people are encompassed despite the high number of companies cited. Third, it may 
mean that labour inspection is focused primarily on concerns other than regularization of employment relationships, such as collection of FGTS funds or occupational safety and health. Taken as a whole, these three alternatives reflect an inspection system that restricts itself to the formal labour market. This argument becomes clearer if we simply read the data backwards. Let us assume that inspection is efficacious, that is, that any irregular employment relationship is always corrected as a result of inspection. In this case, if the relationships of only $1.17 \%$ of the workers encompassed were regularized, then the labour relationships of the remaining 98.83\% were already regular. Throughout the 1990s, individuals working without a signed work card accounted for $35 \%$ to $45 \%$ of the wage labour market in Brazil. The inevitable conclusion is that the inspection system is targeting the wrong businesses, at least when it comes to this specific aspect of inspection, that is, the regularization of the employment relationship.

To put it another way, the market for wage earners without a signed work card stood somewhere between 10 and 15 million in the 1990s, according to data from the PNAD, an annual national household survey conducted by the Brazilian census bureau (Fundação Instituto Brasileiro de Geografia e Estatística). Since labour inspection encompassed twice this many, and since no more than $1.17 \%$ on average were found to be employed irregularly, we are led to the conclusion that inspections did not affect those 15 million wage earners who do not have signed work cards but the over 25 million who do, producing the extremely low regularization rate for the workers reached.

Moreover, it is likely that Ministry of Labour data overestimate the universe covered as well as the efficacy rate of inspection, because the number of workers reached seems very high vis-à-vis the country's formal labour market, which ranged from 20 to 29 million between 1990 and 2003, according to 
Ministry of Labour data. Since inspection seems to target large enterprises $^{27}$, its average effectiveness - that is, the number of workers reached divided by the number of formal workers would at times exceed $80 \%$ of the formal labour market ${ }^{28}$, which seems completely absurd given how everyone complains about the system's low efficacy and coverage.

In the second place, the salary and bonus system for inspectors is based on how many workers are reached, on how many work cards are registered, and on the volume of FGTS funds collected. This system of targets encourages inspectors to overestimate both the efficacy of their work as well as their statistics. In the words of an inspection auditor from São Carlos:

'In terms of productivity, a small company means very little to an inspector. In other words, the smaller the number of employees at a company, the smaller the 'points' assigned by our evaluation system (upon which receipt of our overall salary depends). So if we inspect small companies, we have to work faster and faster. Since this is very hard, it's easier to issue a Notice of Infraction and go away without changing the company's situation (or leaving it worse). It's good to remember that the targets we must meet also contribute to this; we have to inspect a lot and fast. Whether or not detected problems are resolved doesn't seem to matter much' (interview conducted in August 2004).

\footnotetext{
27 This suspicion was strongly reinforced by one woman we interviewed, who bluntly stated: 'It must be made clear that the Ministry of Labour does not inspect the informal labour market. We know the streets are packed with informal workers, but inspection activities ignore this. We inspect companies, that is, organizations where it's possible to identify an employer and his subordinates.'

${ }^{28}$ In 1994, according to Ministry of Labour data (RAIS), there were 23 million wage earners in Brazil with signed work cards, which is precisely how many workers were reached by inspections - thereby yielding $100 \%$ coverage of the formal market.
} 
In other words, the inspector's salary depends on performance statistics. The system thus offers incentives for focusing on large businesses. Furthermore, even when small businesses are inspected, issuance of a Notice of Infraction is not always followed by measures meant to correct the irregular situation. Lastly, as an inspection auditor in Rio de Janeiro stated, when more than one visit is made to a company under inspection, very often each trip is counted separately, thereby inflating statistics.

It should be made clear that the inspection targets mentioned by the auditor from São Carlos referred to FGTS collection. According to a 2004 Ministry of Labour document, since 1996 collection goals have been defined by the Treasury Ministry as part of federal government targets and fiscal efforts. The inspection auditor from Rio de Janeiro cited earlier says that ever since that time, FGTS collection has been the main focus of labour inspection in Brazil.

Table 15 in fact shows that from 1997 on, at least 3\% of total FGTS collection has been a consequence of inspections; in 2002, it came to nearly BRL 1 billion, or $4.3 \%$ of the overall total. This represented the equivalent of $60 \%$ of the Ministry of Labour's budget for 2003 (BRL 1.6 billion). The table also shows that the efficiency of collection has been improving, with the average amount collected per Notice jumping from BRL 24,000 in 1996 to almost BRL 63,000 in 2002. 
Table 15. FGTS Inspection - Brazil, 1996-2002

\begin{tabular}{|l|c|c|c|c|c|}
\hline Year & $\begin{array}{c}\text { Bank Collection } \\
\text { of FGTS (A) }\end{array}$ & $\begin{array}{c}\text { Notices } \\
\text { issued } \\
(\mathbf{B})\end{array}$ & $\begin{array}{c}\text { Total collected } \\
\text { in inspection } \\
\mathbf{( C )}\end{array}$ & $(\mathbf{C}) /(\mathbf{B})$ & $\begin{array}{c}\text { (C)/(A) } \\
\mathbf{\%}\end{array}$ \\
\hline 1996 & $11.671 .686 .175,56$ & 9.385 & $228.404 .462,40$ & $24.337,18$ & 1,96 \\
\hline 1997 & $12.925 .111 .506,46$ & 19.040 & $450.238 .529,74$ & $23.646,98$ & 3,48 \\
\hline 1998 & $16.781 .697 .816,92$ & 18.709 & $550.591 .181,65$ & $29.429,21$ & 3,28 \\
\hline 1999 & $17.408 .212 .152,04$ & 17.062 & $614.837 .075,20$ & $36.035,46$ & 3,53 \\
\hline 2000 & $18.708 .530 .527,10$ & 16.316 & $822.664 .678,16$ & $50.420,73$ & 4,40 \\
\hline 2001 & $21.074 .052 .206,15$ & 15.523 & $737.000 .126,18$ & $47.477,94$ & 3,50 \\
\hline $\begin{array}{l}2002 \\
(*)\end{array}$ & $22.482 .012 .000,00$ & 15.328 & $960.569 .409,70$ & $62.667,63$ & 4,27 \\
\hline
\end{tabular}

$(*)$ Estimate

Source: Ministry of Labour (www.MTE.gov.br)

Considered in conjunction with the TREF shown in the previous table, these data strengthen the argument that the system is targeting ever bigger companies because of the incentives offered to auditors. The auditor from São Carlos said:

'Large companies are much more organized, and their response to the Ministry of Labour is generally professional. In terms of documents, the company almost always has the legally required documents and programs in place already, and if a disagreement arises or even if some irregularity is noted during inspection, there will be dialog with the company; in other words, even if we decide to issue a Notice of Infraction, we know we'll be able to carry inspection through to resolution of the problem, which usually occurs by the deadlines set. And even if large investments are necessary - like when reforms, construction, or the hiring of new personnel is required - with a large company it's also a lot easier to turn to other resources 
like a Conciliation Table, encouraging agreements with the representatives of a given occupation, and so on.'

As we see, inspecting larger companies is also more efficacious, for several correlated reasons: these firms are 'more organized,' they respond to the Ministry of Labour in a 'professional' way, they have the financial wherewithal to comply with demands and any citations (boosting inspector productivity), they do so 'by the deadlines,' etc. Everything conspires to place priority on inspecting these businesses over others, and this must be reflected in the improved rates of regularization noted in recent years.

The focus on larger companies is also a consequence of the Ministry of Labour's use of records biased towards formally established firms. The registry used for inspection purposes is drawn from the RAIS - Relação Anual de Informações Sociais (Annual List of Social Information) - with supplemental information derived from the Census Bureau's economic surveys and other sources, essentially covering the formal labour market. When contact with informal businesses occurs, it is primarily the result of denunciations. However, it would seem reasonable to suspect that the more precarious a labour market and the higher the joblessness rate, the lower the incentive for workers to denounce poor working conditions. A clear example of this constraint is illustrated by Rio de Janeiro's civil construction industry, which we analyse in the next section.

\section{Labour inspection in Rio de Janeiro's civil construction industry}

What are the chances that a company will be caught breaking the law and be sanctioned? In finding an answer to this question, the civil construction industry is a strategic sector. This 
type of work has traditionally been precarious, with high rates of illegality and self-employment. Furthermore, the industry has one of the highest labour accident rates in the country thanks to risky, hazardous working conditions ${ }^{29}$, routinely the object of inspection. We will assess two main features of the situation: the government's inspection power and the action taken by labour unions and employers as inspection agents or intermediaries. As central issues, we will address hiring and dismissal costs, along with recognition of the employment relationship in the form of a signed work card.

\section{The Chances of Getting Caught}

In Rio de Janeiro's civil construction industry, a labour inspection generally is motivated by one of two basic sets of circumstances: first, the commencement of works, when socalled condominiums ${ }^{30}$ must furnish the Ministry of Labour, the union (pursuant to the collective convention), and City Hall with information on how long the job will take, what firms will participate in the condominium, the workers employed, etc.; second, if workers call a special phone number at the union and

${ }^{29}$ Brazil's civil construction industry employed 3.8\% of employees with formal work contracts in 2000, according to RAIS, but it accounted for $7.4 \%$ of the work accidents formally registered with the Ministry of Labour. Data available at www.mte.gov.br.

${ }^{30}$ Created for each project (because each job is always undertaken by a different set of firms), 'condominiums' are becoming common in the civil construction industry. In this context, the term refers to legal entities registered with the National Social Security Institute (Instituto Nacional do Seguro Social) that include employers not required to have a CNPJ number (Cadastro Nacional de Pessoas Juridicas, or National Registry of Legal Entities) but who must nevertheless contribute to the Social Security Administration (Previdencia Social). For example, this would include condo associations, employers of household help, short-term or intermittent employers (e.g., construction, reforms). At the completion of each construction job (a building, for instance), the legal entity responsible for it - that is, the condominium - ceases to exist. 
lodge a denunciation, which may be anonymous. The union receives 80 to 100 denunciations a month. Eight permanent teams of inspectors (or as many as fifteen, if all heads go out on inspections) work every day of the week, visiting jobs according to a previously defined schedule based on the screening and ranking of denunciations. There are now around 8,000 construction sites registered or known of in Rio de Janeiro. While it is true that it is hard to circumvent the legal obligation of formally registering a project with City Hall and the union in the case of larger, more visible jobs, a small building project, or reforms especially, cannot always be identified and therefore inspected.

Let us examine how the first mechanism works: visits at the start-up of registered jobs. An inspection director from the union told us that their visits do not occur on a surprise basis:

We follow a regulated procedure. The big companies advise us at the beginning and end of the job; they file with the union and the Ministry of Labour. Then, when a job is about to begin, we send out an 'Orientation Technical Visit' letter to check whether anything is pending at that site and to reach those workers with the union board's work. We take our checklist, see what's pending, and give them five days to straighten out what needs to be straightened out. We go back, was it taken care of? Great. It wasn't? Then we send an official letter asking them to come here to the union for a Conciliation Table, comprising the union's director of that area and a representative of the team that visited the site with the notification in hand. And we try to bring the company's conduct in line with legislation and the collective labour agreement, while doing our best to avoid taking the matter to the Labour Justice. We exhaust all possibilities for a negotiated settlement, because, in fact, we'd like to keep a partnership relationship going.' 
In this case, 'regulated' procedure means three basic things: first, that the employer association has agreed with these inspection rules; second, that the companies are informed beforehand of the inspection; third, that there is an inventory of items to be inspected, which is of prior knowledge to the business - what the unionist called a checklist. This inventory is also a way of giving the company time to adapt to the rules (five days). If it fails to do so, a series of other negotiating procedures are initiated, beginning with a Conciliation Table at the labour union, where efforts are made to reach an agreement whereby the company will abide by the law and the collective agreement. Should this still fail to achieve the desired end, taking the matter to Labour Court is the last (and undesirable) resort.

The key word for labour union leaders and the heads of employer associations is inarguably 'partnership.' This concept comes into play as part of the second mechanism that prompts inspections. In the words of the same unionist:

'The other form of inspection is when a denunciation is made by a worker. Then we get the site's address, phone number - usually the companies are in our records and we send an official 'Orientation Technical Visit' letter. We let them know we're going to make a visit to provide orientation on occupational safety. We don't surprise them by just showing up. Because that wouldn't be in anyone's interest, right? What we want is that the workers' rights are respected, right? So, when I get there, I'll certainly get a look at the problem; whatever the worker denounced will show up. Now, we never say we went there because of some worker's denunciation, so we don't expose or jeopardize the worker' (interview conducted in July 2004). 
Whether prompted by denunciations or an automatic part of job start-up, during a large share of inspections one member of the visiting team is from the employer association, known by the acronym SindusCon (for Sindicato da Indústria da Construção Civil). According to a SindusCon member we interviewed, this partnership is advantageous to both sides, because it is in SindusCon's interest to meet the requirements of occupational safety standards and thus reduce work accidents ${ }^{31}$. An agent of the Regional Labour Office also participates, though not always. According to unionists, this makes the visits more efficacious. The regional delegate has the power to shut down the job on the spot, if, as one leader said, there is 'a major calamity, and the company doesn't want to fix it right then and there.' Furthermore, since the delegate is the Ministry of Labour's executive agent par excellence, his presence lends inspection teams more weight. Together with the presence of representatives of workers and bosses, his being there tends to hinder rather unorthodox or openly corrupt practices on the part of any of the three agents (at least in theory).

Since these words are from the discourse of leaders, we of course cannot take them at face value. The union does not maintain a reliable record of its visits or of resultant compliance with occupational safety standards and labour rights, data essential to accurately measuring improvements in inspection efficacy or effectiveness over time. In 2003, according to one leader, more than 300 new work cards were registered between March and June as a consequence of inspections, but there is no way of knowing whether this figure is high or low in historical terms. It certainly seems low given that the estimated number of

$\overline{31}$ Both the union and the association made it a point to emphasize the drop in deaths caused by work accidents in the civil construction industry in 2003 (three), comparing this figure with the year the new labour union board took office (seventeen). 
informal workers surpassed 100,000 in $2002^{32}$, or even given the 32,000 wageworkers who have no signed work card. At the pace of inspections in 2003, it would take over 25 years to register all current wage earners with unsigned work cards, without even taking into account the new, non-registered employment relationships born each day in the civil construction industry. And nothing guarantees that an employment relationship registered today will still be so tomorrow.

Within the civil construction industry, a condominium's principal construction firm is almost never the largest employer, and employees are sometimes distributed across dozens of subcontractors. Inspection efficacy therefore depends upon the union's ability to reach the fringes of this web of outsourcing. With this in mind, unions adopt the policy of not negotiating with subcontractors but rather with the condominium's main firm. It is important that this procedure is part of the collection labour convention; in other words, it is up to the main company to ensure that their subcontractors abide by legislation and the collective agreement. This underscores what one business leader said and a judge seconded: consolidated jurisprudence - that is, that the main company has nondiscretionary responsibility for the others - ultimately forces it to exercise some form of oversight of subcontractors. Obviously, this is not always possible.

According to one inspection director, the chief obstacle to inspection for both the union and inspection auditors is actually the scale of a business, that is, low capitalization. This is a very effective economic obstacle because a heavy citation may make a company's operations unviable and lead to job cuts. Here we have yet another reason - on top of the institutional and legal incentives examined earlier - for inspections to take place

${ }^{32}$ Estimate based on the 2000 census and projected based upon PNAD-2002 information for the Metropolitan Region of Rio de Janeiro. 
chiefly at medium or large businesses. The choice does have its rationale. According to 2000 census data for the city of Rio de Janeiro, $64 \%$ of the slightly over 3,000 people who declared themselves employers headed businesses employing a maximum of 10. Based on Annual List of Social Information (RAIS) data for 2002 - which measure only those with jobs registered on work cards - firms with up to 10 employees accounted for $70 \%$ of all 3,156 formally registered companies; the figure rises to $82 \%$ if we include firms with up to 19 employees. However, the proportion of workers employed at companies with up to 19 employees was only $20.6 \%$, according to the same RAIS. On the other hand, companies with 50 or more employees accounted for only $33.1 \%$ of the total but employed $61.3 \%$ of the labour force holding signed work cards. The odds of the union or the Ministry of Labour conducting an inspection at a given company are greater, the greater the company's footing within the formal market - that is, the easier it is to find (when it has a telephone or address that can be traced in either union or Census Bureau records). Consequently, we can assume it likely the union and the Ministry of Labour are covering fewer than one-third of the firms that are really out there (considering both the formal and informal sectors), while nearly two-thirds of the employed labour forced represents a potential realm of action.

We can thus state that although the chances of being caught for breaking the law are not zero in Rio de Janeiro's civil construction industry, nor are they very high, except in the case of large projects, large work sites, or projects in highly visible locations; for instance, when downtown buildings undergo reform. On a scale of 0 to 100 , the chance of a large work site being inspected, after having been denounced, is 100. These odds fall as the size and social visibility of a project decrease. On the other hand, even if a denunciation has been lodged, the odds that the union or Regional Labour Office will inspect a 
small project undertaken by a small contractor (e.g., a reform, a country home, or even a home in the city) are virtually nil. Thus, the potential for an inspection is a direct function of the size of the job and the firms involved in it, and also of whether a denunciation is lodged. The key question is consequently: What are the real chances that breaching a right will prompt a denunciation?

These odds are not randomly distributed across the working population. Some workers are more prone than others to come forward with a denunciation. This is a direct function of their knowledge of worker rights and an inverse function of their fear that they may end up losing their job, with workers weighing in the cost of being fired. When joblessness is high, workers may be somewhat less concerned about stability than simply in about getting a job, which may be enough to dissuade them from lodging a complaint, no matter how clear they may be about workers' rights. When the market is really bad, a worker's fear of losing his job may also outweigh his confidence that his denunciation will remain anonymous (for example, if he uses the union's disque-denúncia - dial-a-denunciation - line).

\section{The chances of being punished}

In a labour dispute ensuing from a breach of rights, there are three main phases to consider, each associated with one specific institution: 1) The regulation of standards and inspection of company compliance, under the responsibility of the Ministry of Labour; inspection itself encourages a business to conform to standards. 2) Defiance of or reluctance to abide by standards, which prompts the opening of a negotiation process at the union or Regional Labour Office, or at both; this process may be conducted by the Office or by the Public Ministry of Labour, pursuant to its power to open civil inquiries 
and establish the legally binding contracts known as termos de ajuste de conduta (TAC). 3) If these instruments do not settle the issue, the parties in dispute will move to the judicial branch, that is, the Labour Court.

The presence of the Regional Labour Delegate or another professional from the Office facilitates resolution via the first path, but understaffed Offices cannot respond to every call from the civil construction industry. So options 2 and 3 are almost always within the realm of possibility whenever an inspection takes place. According to leaders of both the union and the employer association, everyone's prime goal is to reach an understanding; this generally happens at Conciliation Tables (in the case of occupational safety fraud) or through the Civil Construction Industry's Initial Conciliation Commission (Comissão de Conciliação Prévia da Construção Civil, or CCP-CC). As in other cases, the CCP-CC is a mechanism that has come to serve as the first real setting for conflict resolution revolving around the existence of contracts and mainly contract rescission.

In the case of occupational safety and health issues, solutions are either found immediately, at the workplace, or settled at a Conciliation Table. The third option is almost always inefficacious. A union leader from the civil construction industry stated adamantly that the Labour Court and Public Ministry of Labour are very slow, when you consider that a construction project may take from three months to a year, rarely extending for three years. In his words, 'By the time the courts decide to take action, the job is over, you know?' Nevertheless, the same leader said companies usually respect occupational safety regulations because 'nobody wants to get a bad name in the business, to be branded as working unsafely.' Moreover, a non-negligible portion of formally established enterprises have ISO certification, whose parameters include occupational safety and benchmarking for accidents. We saw earlier that one director of the employer association shares 
the same viewpoint. And the labour leader added: 'A big company that has certification will not accept subcontractors on its job if they don't follow the standards.'

The problem of course are the large businesses that don't have certification and the small and medium-sized ones not inspected by the union because they operate on the informal market. In any case, both union and employer association leaders affirm that, thanks to the partnership they have developed in relation to this and other matters, occupational safety in Rio de Janeiro's civil construction industry has greatly improved in recent years - so much that by July of 2004 only one fatal accident had been reported for the year.

Unfortunately, it was not possible to access consolidated data on the evolution of work accidents in the civil construction industry in the city of Rio so that we could verify the statements made during interviews ${ }^{33}$. What is certain is that official data which are always underestimated, in proportion to the degree of informal relations within a given economic sector ${ }^{34}-$ indicate that slightly more than 1,700 work accidents occurred in the civil construction industry in the state of Rio de Janeiro in 2000 (where half of the state's population resides in the capital). Historically, this sector has made the biggest contribution to work accident

\footnotetext{
33 A bibliographic research project by Mendes (2003) surveyed all theses and dissertations on health and labour in Brazil since 1950; it located only one master's thesis on the civil construction industry in Rio de Janeiro, and this was for 1987. The topic has not been studied by Brazilian scholars, even though the civil construction industry has always had the highest work accident rate in the country.

${ }^{34}$ Wunsch Filho (1999) argues that productive restructuring has contributed to a drop in the number of work accidents in Brazil's industrial sector. However, we believe that the most important cause is greater informalization of labour relations, which means fewer workers are covered by social security and, consequently, there is less official information on the accidents that actually occurred
} 
statistics in the state as well as to the under-representation of these accidents in statistics.

When it comes to labour contract rights and especially contract rescission, the main mechanism for addressing disputes is the Initial Conciliation Commission. Its actions have a substantial impact on the costs of obeying or disobeying legislation, especially when the question is dismissal. These Conciliation Commissions comprise representatives of labour unions and employer associations. Under law, before any complaints are filed with the Labour Justice, they must first go through a commission, if one has been set up within the company or union in the city in question. Like others, the civil construction industry's commission was soon transformed into a kind of labour court with no presiding judge to rule on cases. The following excerpt from an interview with a union leader who participates in the commission is enlightening in many ways:

We have our Initial Conciliation Commission, where we discuss these issues too, like FGTS. Because a company sometimes wants to [make severance payments] but just isn't able to. So we advise the workers to enter into an agreement. This can be during dismissal or even while their contract is still in effect. [...] Today these commissions have taken pressure off the Labour Court. Most of the companies that used to try to settle these agreements in court now do so through the commission. We've established a norm at the commission that no worker can receive less than $60 \%$ of what he has a right to. No agreement can be made for less than $60 \%$. A norm defined by the union. Now if a worker wants to enter into a contract rescission, he's taking on that risk. He knows what his needs are; it's his money. If he says 'no, I won't take less', what can you do? He worked for it; it's his right, isn't that true? So we show him the 
legal options so he can go to court and get it. [...] All small entrepreneurs have the same standardized discourse, saying that the labour courts are paternalistic. Well, the labour courts sometimes sentence the employer to pay in twelve instalments, with the first instalment two months from now! With a father like that, I don't need an enemy! Our outlook is to let the negotiations take place so the issue doesn't go to court, so the workers don't end up losing out on their rights down the line. This is why the commissions were created, and the principle that $60 \%$ is assured first thing. [...] We came up with this figure based on a calculation of what the worker earns. Because his indemnification can't be less than the wage he was earning. He has a right either to that level or more than that. That's the intention. [...] Most of the time, it ends up at $60 \%$. That's become the rule now; no company grants less than this' (interview conducted in June 2004).

It is worth examining certain points brought up by this union leader, starting with the fact that workers are 'advised to enter into agreements', that is, to settle the matter through the commission and not the Labour Court. Of course, if a worker still wants to go to court, he has the right to do so, but the leader's words leave no doubt that the union does not want to see this solution. The worker will be on his own if he opts to resort to the courts. Second, it is clear that companies have also preferred to settle severance pay disputes through the commission and not the Labour Justice. This preference undoubtedly has to do with the union's position that no agreement can be reached in which the worker receives less than $60 \%$ of the amount due. What is most striking is that the union leader presents this value as being in the worker's interest, since he would otherwise receive less through the Labour Court or perhaps receive it under disadvantageous terms, for example, in 'twelve monthly instalments.' The Labour 
Justice is painted as a place where the worker loses his rights, or has them granted under disadvantageous conditions.

This is undoubtedly an important disincentive for employers to abide by legislation regarding dismissals, since they know their 'punishment' will be a Conciliation Table where agents lacking any enforcement power will have no problem accepting an agreement under which the bosses pay $60 \%$ of the value actually due. Consequently, it is clear the union's decision to opt for an out-of-court settlement rather than penalizing businesses that behave illegally has a bearing on the cost of breaking the law. There are no outside incentives or injunctions that would compel a firm to formalize contracts with their workers. Insofar as there are any incentive to do so, they are internal ones - that is, the main company has an ISO or other qualification, and therefore forces its subcontractors to obey the law.

\section{Conclusion}

Labour inspection in Brazil follows the standards defined by the ILO in 1947. Today, its supporting institutions are a little better equipped than ten or fifteen years ago. Information technology is used to handle and produce information, bureaucratic channels flow more smoothly, and labour inspectors receive regular training. There is a nationwide inspection system in place, with 27 Regional Labour Offices in all and a little over two thousand inspection auditors. In formal terms, this institutional design would seem suitable for ensuring effective, efficacious, and efficient labour inspection: effective because it seems to reach a great number of workers as a proportion of the active labour force; efficacious because it improves labour relations and corrects illegal situations, like the non-collection of FGTS or non-signature of work cards; and efficient because it optimizes its resources, that is, the system spends about one-fourth of the 
Ministry of Labour's investment resources, while its structure is more robust and its staff more numerous. Furthermore, inspection oversight procedures also seem well designed to deter fraud and diminish corruption. Similarly, for instance, defining stricter deadlines on the administrative processing of fines - which should take sixty days at most - is intended to discourage enterprises from finding ways to defer payment. In order to confront the legal processes that follow administrative ones, a firm must be able to rely on sound, dependable in-house counsel. This encourages small and medium businesses to abide by the law when inspected. Consequently, the system produces quite optimistic statistics on the results of labour inspection.

Here is where the trouble begins. In the first place, if we take these statistics at face value, labour inspections reach $80 \%$ or more of Brazil's formal labour market every year, or close to $50 \%$ of wage earners as a whole (i.e., workers with a formal contract as well as those without). However, we have seen that a very small proportion of the potential target population actually benefits from inspections. All indications are that the selective incentives offered by the system induce inspectors to cherry-pick businesses that in fact do not need to be inspected as far as proper registration of employment relationships because they are already abiding by the law. Thus, while inspection perhaps discourages regularly inspected entrepreneurs from sliding into illegal behaviour in other areas as well, it does not seem capable of drawing into the system new agents whose operations are completely illegal and ergo invisible to the eyes of the Ministry of Labour, whose records are almost entirely based on information provided by companies themselves on the Annual List of Social Information (RAIS).

The system's second limitation is its lack of material resources, something the impressive inspection statistics actually hide. Each year, the 2,000 some inspectors can choose from among two to three million formally established firms with at 
least one employee, once again according to RAIS data. This figures out to an average of 1,000 to 1,500 companies that can potentially be visited per auditor per year, or an average of five to seven companies per business day. The number of inspectors is obviously low, particularly because these calculations do not even include informal businesses. Accordingly, the Regional Labour Offices are challenged to respond to denunciations that cannot be covered by available staff. The system is not equipped to exercise one of its most essential prerogatives: surprise visits to businesses of any type or size. Instead, it depends upon the extent to which individual workers, or their representatives, are willing to or interested in denouncing illegal working conditions.

The answer to the question posed by this chapter - What are the chances that an entrepreneur engaging in illegal practices will be caught and, if caught, punished or compelled to fix the detected breaches? - is that a gradation exists between two welldefined extremes. At one end are the informal companies of any size that have no business registration and do not formalize labour relationships; in their case, the chances of being inspected are slender and depend solely on worker denunciation. Since the likelihood that workers will lodge such a denunciation is inversely proportionate to their fear of unemployment, the odds of their doing so decline proportionately in a more precarious labour market and when joblessness rates are high. This constraint was made quite apparent in our analysis of Rio de Janeiro's civil construction industry. At this end of the spectrum, we also find self- employed workers and liberal professionals, the latter generally employing one or two administrative helpers. In 2003, wage earners without signed work cards and self-employed workers (including liberal professionals) accounted for $45.8 \%$ of the economically active population, according to PNAD data. This portion of the population will not be reached by inspection, except by pure chance. 
At the other extreme we find formally registered firms whose chances of being caught when engaging in illegal working relationships is directly proportional to the company's size. Small companies, with up to 20 employees, are rarely inspected because the system's selective incentives encourage inspection of larger companies as understaffed auditors are forced to limit how many firms they inspect. Our data and interviews suggest that the 'magic' number of employees that ranks a business among those that may be inspected is fifty. Therefore, if a firm has fifty or more employees and is denounced for illegal practices, the odds are quite high that it will be inspected.

This is where the system's third important limitation comes in: the low rate of regularized employment relationships may reflect the fact that large enterprises have the material means to postpone solution of any irregularity well beyond the sixty-day legal limit for administrative processes. If an appeal is made, time limits are virtually suspended, because Brazilian courts are slow and a sentence can take years. This is why the labour inspectors we interviewed repeatedly affirmed that it is the small and medium businesses that end up paying fines or correcting improper labour relations when inspected. For them, the cost of taking legal action in order to postpone things can be too high. This may explain why $21 \%$ of inspected companies were cited whereas the rate of correction of irregular employment situations was only $1.17 \%$. Large enterprises are either 'more legal' or manage to avoid contractual obligations through judicial action.

Most companies lay between these extremes, though not the greatest proportion of employed workers. It is highly unlikely these firms will be inspected. They are formal companies with a substantial number of workers. Even if denounced, they will take advantage of loopholes in the inspection system to drag settlement out until the last minute legally possible. Here is a good place to point out the observation of one inspection 
auditor: that political influence plays a role in the appointment of Regional Labour Delegates - and these are the people who impose the fines. In any case, the odds that a company will be inspected are still directly proportional to the odds that its workers will denounce irregularities.

In recent years, the federal government has sponsored public educational campaigns and advertised telephone numbers where anonymous denunciations can be made. The efficacy of these instruments can be measured not so much by how they curb the routine violation of labour rights but by their role in more dramatic situations, like the 'reduction to a condition analogous to slavery' and the use of child labour. Three labour inspectors were recently murdered in the state of Minas Gerais during the exercise of their duties, apparently at the orders of a rancher who was using forced labour on his ranches and who had ties to a powerful local politician. Denunciations sprang up in Pará, Bahia, Pernambuco, Rio Grande do Sul, São Paulo, and other states, and it would appear that efforts to combat slave labour (used especially when a debt is owed) have been effective. The same can be said about child labour, which is being combated not only through inspection but also through minimum wage policies, almost all linked to school registration.

Returning specifically to the question posed by this chapter, labour inspection seems to be aimed at companies that are less likely to engage in illegal activities; the outcome is high effectiveness (many workers reached through inspection) but extremely low relative efficacy (the number of employment relationships that are regularized as a result of inspection activities). Still, the fines system and collection process have proved to be sufficiently coercive to force smaller businesses to regularize their situation and pay their fines. As always, however, larger companies can count on the legal system's inefficiency to find a way around legal compliance. 


\section{BibliogRAPHY}

Abramo, Lais W. (1999), O resgate da dignidade: greve metalúrgica e subjetividade operária. Campinas, Editora da Unicamp.

Aldé, Alessandra; Mendes, Gabriel G.; Figueiredo, Marcus. (2007), 'Imprensa e eleições presidenciais: Natureza e consequências da cobertura das eleições de 2002 e 2006', in Venício A. Lima ed. A mídia e as eleiçoes de 2006. São Paulo: Fundação Perseu Abramo, pp. 65-87.

Alemão, Ivan; Soares, José L. (2009), Conciliar é 'legal’? Uma análise crítica da aplicação da conciliação na Justiça do Trabalho. Revista Justiça do Trabalho, Ano 26, No. 30.

Alencastro, Luiz Felipe de. (2000), O Trato dos Viventes. Formação do Brasil no Atlântico Sul. São Paulo, Cia. das Letras.

Alvim, Rosilene. (1997), A seducão da cidade: Os operários-camponeses e a fábrica dos Lundgren. Rio de Janeiro: Graphia.

Amadeo, Edward; Camargo, José M. (1996) 'Instituições e mercado de trabalho no Brasil'. in José M. Camargo ed., Flexibilidade do mercado de trabalho no Brasil. Rio de Janeiro: FGV, cap. 2.

Andrade, Manuel C. de. (1980 [1963]), A terra e o homem do Nordeste. São Paulo, Ciências Humanas, $4^{\mathrm{a}}$ Edição (revista e atualizada).

Antunes, Ricardo. (1988), A rebeldia do trabalho. O confronto operário no $A B C$ Paulista: as greves de 1978/80. Campinas: Editora da Unicamp.

Antunes, Ricardo. (2003), Os caminhos da liofilização organizacional: as formas diferenciadas na reestruturação produtiva no Brasil. Idéias, Vol. 9, No. 1, pp. 13-24.

Appy, Bernard. (1993), 'Questão fiscal: crise e concentração de renda', in Bernard Appy et al., Crise brasileira, anos oitenta e governo Collor. São Paulo: DESEP/CUT, pp. 7-82.

Araújo, Angela M. C.; Gitahy, Leda. (2003), 'Reestruturação produtiva e negociações coletivas entre os metalúrgicos paulistas’. Idéias, Vol. 9, No. 2, pp. 65-112. 
Araújo, Ricardo B. (2005), Casa Grande \& Senzala e a Obra de Gilberto Freyre nos Anos 30. São Paulo, Ed. 34.

Arbix, Glauco T. (1996), Uma Aposta no Futuro. São Paulo: Scritta.

Azevedo, Célia M. M. (1987), Onda negra, medo branco: O negro no imaginário das elites. Brasil, Século XIX. Rio de Janeiro: Paz e Terra.

Baltar, Paulo A.; Leone, Eugenia T.; Maia, Alexandre G.; Salas, Carlos. ; Krein, José Dari; Moretto, Amilton; Proni, Marcelo W.; Santos, Anselmo. (2010), Moving towards decent work. Labour in the Lula government: Reflections on recent Brazilian experience. Global Labour University working Papers, Vol. 9, pp. 1-38 (available at http:/ / www.global-labour-university.org/fileadmin/ GLU_Working_Papers/GLU_WP_No.9.pdf, accessed in Sept. 2011).

Barbosa Filho, Fernando H.; Pessôa, Samuel A.; Veloso, Fernando A. (2010), Evolução da produtividade total dos fatores na economia brasileira com ênfase no capital humano - 1992-2007. Revista Brasileira de Economia, Vol. 64, No. 2, pp. 91-113.

Barros, Ricardo P. et al. (2007), 'A desigualdade de renda no Brasil encontra-se subestimada? Uma análise comparativa com base na PNAD, na POF e nas Contas Nacionais'. Textos Para Discussão, No. 1263, Rio de Janeiro: IPEA.

Barros, Ricardo P.; Corseuil, Carlos. H.; Gonzaga, Gustavo. (1999), 'Labour market regulations and the demand for labour in Brazil.' Discussion Paper No. 398, Department of Economics: PUC- Rio.

Barros, Ricardo P.; Mendonça, Rosane. (1996), 'Flexibilidade do mercado de trabalho brasileiro: uma avaliação empírica', in José M. Camargo ed., Flexibilidade do mercado de trabalho no brasil. Rio de Janeiro: FGV, pp. 157-201.

Belot, Michèle.; Ours, Jan V. (2001), Unemployment and labour market institutions: An empirical analysis. Journal of Japanese and International Economics, No. 15, pp. 403-418.

Belot, Michèle.; Ours, Jan V. (2004), Does the recent success of some OECD countries in lowering their unemployment rates lie in the clever design of their labour market reforms? Oxford Economic Papers, No. 56, pp. 621-642.

Benevides, Maria V. M. (1981), A UDN e o Udenismo. Ambiguidades do liberalismo brasileiro (1945-1965). Rio de Janeiro: Paz e Terra.

Bensusán, Graciela. (2005), La inspección del trabajo en México: Diseño legal y desempeño real. Paper presented at the seminar Labour Inspection and Labour Markets, MIT, January.

Berg, Janine; Ernst, Christoph; Auer, Peter (2006), Meeting the employment challenge. Argentina, Brazil and Mexico in the global economy. London: Lynne Rienner. 
Berry, Albert; Mendez, Maria T. (1999), Policies to promote adequate employment in Latin America and the Caribbean (LAC). Employment and Training Papers No. 46, ILO, Geneva.

Bertola, Giuseppe; Boeri, Tito; Cazes, Sandrine. (1999), Employment protection and labour market adjustment in OECD countries: Evolving institutions and variable enforcement. Employment and Training Papers No. 43, ILO, Geneva.

Bértola, Luis et alii. (2009), Income distribution in Brazil: 1870-1920. Paper presented at the conference 'A Comparative Approach to Inequality and Development: Latin America and Europe'. Instituto Figuerola, Madrid: Universidad Carlos III, 8-9 May.

Bielschowsky, Ricardo. (1996), Pensamento econômico brasileiro: o ciclo ideológico do desenvolvimentismo. Rio de Janeiro, Contraponto ( $3^{a}$ edição).

Blass, Leila M. da S. (1999), 'Novo sindicalismo: persistência e descontinuidade', in Iram J. Rodrigues ed., O Novo Sindicalismo vinte anos depois. Petrópolis: Vozes.

Boltanski, Luc; Chiapello, Eve. (2002), El nuevo espiritu del capitalismo. Madrid: Ediciones Akal.

Bonelli, Regis. (1999), 'A Reestruturação industrial brasileira nos anos 90: Reação empresarial e mercado de trabalho', in OIT/MTE. Abertura e ajuste do mercado de trabalho no Brasil. Brasília: OIT/MTE, pp. 87-115.

Bourdieu, Pierre. (1979), La Distinction. Paris: Minuit.

Bretas, Marcos Luiz. (1997), A guerra das ruas. Povo e polícia na cidade do Rio de Janeiro. Rio de Janeiro: Arquivo Nacional.

Bruschini, Cristina; Lombardi, Maria R. (2003), Hommes et femmes sur le marché du travail au brésil. Travail, genre et societies, No. 10, pp. 149-171.

Buonicore, Augusto C. (2000), Sindicalismo vermelho: a política sindical do PCB entre 1948 e 1952. Cadernos AEL, Vol. 7, No. 12/13 (available at http://segall.ifch.unicamp.br/publicacoes_ael/index.php/cadernos_ael/ article/view/98, accessed in Jul. 2010).

Camargos, Regina C. (2009), Negociação coletiva: trajetórias e desafios. Belo Horizonte: RTM.

Candido, Antonio. (1964), Os parceiros do Rio Bonito. Rio de Janeiro: José Olympio.

Cappellin, Paula. ed. (2005), A experiência dos Núcleos de Promoção da Igualdade de Oportunidades e Combate à Discriminação no Emprego e na Ocupação. Brasilia: ILO.

Cardoso, Adalberto. (1999a), Sindicatos, trabalhadores e a coqueluche neoliberal: A Era Vargas acabou? Rio de Janeiro: FGV.

Cardoso, Adalberto. (1999b), A trama da modernidade. Pragmatismo sindical e democratização no Brasil. Rio de Janeiro: Revan. 
Cardoso, Adalberto. (2000), Trabalhar, verbo transitivo. Destinos profissionais dos deserdados da indústria automobilística. Rio de Janeiro: FGV.

Cardoso, Adalberto. (2003), A década neoliberal e a crise dos sindicatos no Brasil. São Paulo: Boitempo.

Cardoso, Adalberto. (2004), Industrial relations, social dialogue and employment in Argentina, Brazil and Mexico. ILO Employment and Strategy Papers, No. 7. Geneva: ILO.

Cardoso, Adalberto. (2010), A construção da sociedade do trabalho no Brasil. Uma investigação sobre a persistência secular das desigualdades. Rio de Janeiro: FGV.

Cardoso, Adalberto. (2015), Dimensões da crise do sindicalismo brasileiro. Caderno CRH, Vol. 28, No. 75, pp. 35-62.

Cardoso, Adalberto. (2015b), "Your defensive fortress': Workers and Vargas'ss legacies in Brazil," in Teri Caraway, Maria L. Cook and Stephen Crowley eds., Working through the past; Labor and authoritarian legacies in comparative perspective. Ithaca and London: Cornell University Press, pp. 164-178.

Cardoso, Adalberto; Comin, Alvaro Augusto; Guimarães, Nadya A. (2004), Le Rejetés de la modernisation. Sociologie du Travail, Vol. 49, p. 54-68.

Cardoso, Adalberto et al. (2006), 'Os Deserdados da Indústria. Reestruturação Produtiva e Trajetórias Intersetoriais de Trabalhadores Demitidos da Indústria Brasileira', in Nadya Guimarães and Helena Hirata eds., Desemprego: Trajetórias, identidades, mobilizações. São Paulo: Senac, pp. 45-90.

Cardoso, Adalberto; Gindin, Julián. (2009), Industrial relations and collective bargaining: Argentina, Brazil and Mexico compared. Working Paper No. 5, Industrial and Employment Relations Department, ILO (available at http://www.ilo.org/public/english/dialogue/ifpdial/downloads/papers/ wp5.pdf)

Cardoso, Adalberto; Lage, Telma. (2007), As normas e os fatos: desenho e efetividade das instituicões de regulação do mercado de trabalho no Brasil. Rio de Janeiro: FGV.

Cardoso Jr., José C. (2000), Desestruturação do mercado de trabalho brasileiro e limites do seu sistema público de emprego. Lecture presented at the '3rd Latin American Congress of Labour Sociology', Buenos Aires.

Cardoso Jr., José C.; Gonzales, Roberto; Stivali, Matheus; Amorim, Brunu; Vaz; Fábio. (2006), Políticas de emprego, trabalho e renda no Brasil: desafios à montagem de um sistema público, integrado e participativo. Texto Para Discussão, No. 1237, Brasília: IPEA.

Cardoso, Fernando H. (1969), 'Proletariado no Brasil: situação e comportamento social', in idem, Mudanças sociais na América Latina. São Paulo: Difusão Europeia do Livro. 
Cardoso, Luis A. (2001), Após-fordismo e participação: Reestruturação produtiva contemporânea e a nova racionalização do trabalho na indústria automobilística brasileira. PhD Dissertation: COPPE/UFRJ.

Carneiro, Francisco G.; Henley, Andrew. (1998), Wage determination in Brazil: the growth of union bargaining power and informal employment. Journal of Development Studies, Vol. 34, No. 4: 117-138.

Carone, Edgard. (1982), O P.C.B. São Paulo: Difel, 3 Vols.

Carone, Edgard. (1988), O Estado Novo (1937-1945). Rio de Janeiro: Bertrand Brasil (5th edition).

Carvalho, José M. de. (1980). A construção da ordem: A elite política imperial. Brasília: UnB.

Carvalho, José M. de. (1987), Os Bestializados. O Rio de Janeiro e a República que não Foi. São Paulo: Companhia das Letras.

Carvalho, Ruy Q. (2001), Relaçoes interfirmas, governança e desenvolvimento tecnológico na cadeia automotiva brasileira. Paper presented at the seminar 'The Automotive Industry in the Americas', Rio de Janeiro. Manuscript.

Castel, Robert. (1998), As metamorfoses da questão social: Uma crônica do salário. Petrópolis: Vozes.

Chalhoub, Sidney. (1990), Visões da liberdade: uma historia das ultimas décadas da escravidão na corte. São Paulo: Companhia das Letras.

Chevalier, Louis. (1984 [1958]), Classes laboriouses et classes dangereuses à Paris pendant la première moitié du XIXème siècle, Paris: Hachette (2nd edition).

CNI/SENAI (National Confederation of Manufacturing/National Service of Manufacturing). (1998), Modernização, emprego e qualificação profissional. Rio de Janeiro: CNI/SENAI.

Collier, Ruth B.; Collier, David. (1991), Shaping the political arena. Princeton: Princeton University Press.

Conrad, Robert. (1994), Children of God's fire. A documentary bistory of Brazilian slavery. University Park: Pennsylvania State University Press.

Cook, Maria L. (2007), The politics of labour reform in Latin America. Between flexibility and rights. University Park: Penn State University Press.

Coriat, Benjamin. (1991), Penser a l'envers: Travail et organization dans l'emtreprise japonaise. Paris: Cristian Bourgeois.

Corrêa, Mariza. (1994), 'Repensando a família patriarcal brasileira', in Antônio A. Arantes et al. eds., Colcha de retalhos: estudos sobre a família no Brasil. Campinas: Editora da Unicamp (3rd edition).

Costa Sobrinho, Pedro V. (1992), Capital e Trabalho na Amazônia Ocidental: Contribuição à História Social e das Lutas Sindicais no Acre. São Paulo: Cortez; Rio Branco: EDUFAC. 
Costa, Ana Paula P. (2005), Estratégias sociais e construção da autoridade: uma análise das práticas de reprodução social dos oficiais dos corpos de ordenanças na busca pelo mando. Mneme - Revista de Humanidades. Vol. 7. No. 18 , out./nov. p. 469-514.

Costa, Emilia V. (1982 [1966]), Da senzala à colônia. São Paulo: Ciências Humanas (2nd edition).

Costa, Emilia V. (1999), Da Monarquia à República: momentos decisivos. São Paulo: UNESP (7th edition).

Costa, Marcia S. (2006), Despotismo de mercado: medo do desemprego e relacõos de trabalho. João Pessoa: UFPb.

Coutinho, Luciano. (1997), 'A especialização regressiva: um balanço do desempenho industrial pós-estabilização', in João P. R. Velloso ed., Brasil: desafios de um país em transformação. Rio de Janeiro: Fórum Nacional/José Olympio Editora.

Coutinho, Ronaldo do L. (1980), Operário de construção civil: urbanização, migração e classe operária no Brasil. Rio de Janeiro: Achiame.

Dal Rosso, S. (1997), A Jornada de Trabalho na Sociedade. Brasilia: UnB.

Dassin, Joan. (1978), Censorship in Brazil. Washington Office on Latin America.

Dávilla, Jerry. (2003), Diploma of whiteness. Race and social policy in Brazil, 19171945. Durham/London: Duke University Press.

Dean, Warren. (1971), A Industrialização de São Paulo: 1880-1945. São Paulo, Difel.

Dean, Warren. (1977), Rio Claro: Um sistema brasileiro de grande lavoura. Rio de Janeiro: Paz e Terra.

Delgado, Lucilia A. N. (1986), O Comando Geral dos Trabalhadores no Brasil: 1961 1964. Petrópolis: Vozes.

Delgado, Lucilia A. N. (1989), PTB: do getulismo ao reformismo, 1945-1964. Rio de Janeiro: Marco Zero.

Dias, Everardo. (1962), História das lutas sociais no Brasil. São Paulo: EDAGLIT. Dias, Maria Odila Leite da Silva. (1995), Quotidiano e poder em São Paulo no século XIX. São Paulo: Brasiliense (2nd revised edition).

DIEESE (Inter-union Department of Statistics and Socio-Economic Studies). (1997), Impactos das recentes transformações no mundo trabalho sobre as contrataçöes coletivas. São Paulo: DIEESE.

Diniz, Eli; Boschi, Renato. (1976), Empresariado Nacional e Estado no Brasil. Rio de Janeiro: IUPERJ (2 vols).

Douglas, Mary. (1986), How Institutions Tbink. Syracuse: Syracuse University Press.

Duby, Georges. (1987), Economia rural e vida no campo no ocidente medieval. Lisboa: Edições 70.

Durham, Eunice R. (1973), A caminho da cidade: a vida rural e a migracão para São Paulo. São Paulo: Perspectiva. 
Dwyer, Tom. (2006), Vida e morte no trabalbo: Acidentes do trabalho e a produção social do erro. Campinas: Editora da Unicamp.

Egger, Philippe. (1999a), 'El desempleo de los jóvenes en los países andinos (Colombia, Ecuador, Perú y Venezuela). Situación y perspectivas,' ILO Multidisciplinary Technical Team for Andean Countries, Lima, Peru.

Egger, Philippe. (1999b), 'El mercado laboral en los países andinos: un compendio de datos sobre empleo y salarios.' Working Paper, No. 121, ILO Multidisciplinary Technical Team for Andean Countries, Lima, Peru. Eisenberg, Peter L. (1974), The sugar industry of Pernambuco: Modernization without change, 1840-1919. Berkeley: University of California Press.

Eisenberg, Peter L. (1989), Homens esquecidos: escravos e trabalhadores livres no Brasil. Campinas: Editora da Unicamp.

Elster, Jon. (1979), Ulysses and the sirens. Studies in rationality and irrationality. Cambridge: Cambridge University Press.

Erickson, Kenneth P. (1979), Sindicalismo no processo politico no Brasil. São Paulo: Braziliense.

Faria, Vilmar E. (1983), 'Desenvolvimento, urbanização e mudança na estrutura do emprego: a experiência brasileira', in Bernard Sorj and Maria H. Tavares de Almeida eds., Sociedade e Política no Brasil pós-64. São Paulo: Brasiliense.

Fausto, Boris. (1977), Trabalho Urbano e Conflito Social. São Paulo, Difel.

Fausto, Boris. (1984), A criminalidade em São Paulo, 1880-1924. São Paulo: Brasiliense.

Fernandes, Florestan. (1960), Mudanças sociais no Brasil. São Paulo: Difusão Europeia do Livro.

Fernandes, Florestan. (1978), A integração do negro na sociedade de classes. São Paulo: Ática, 2 vols.

Ferreira, Jorge. (1997), Trabalbadores do Brasil. O imaginário popular. Rio de Janeiro: FGV.

Ferreira, Jorge. (2010), 'O nome da coisa: o populismo na política brasileira', in Jorge Ferreira ed., O populismo e sua história: debate e crítica. Rio de Janeiro: Civilização Brasileira.

Ferreira, Jorge. (2011), João Goulart: Uma biografia. Rio de janeiro: Civilização Brasileira.

Ferreira, Jorge; Reis, Daniel A. eds. (2007). A esquerda no Brasil. Nacionalismo e reformismo radical: 1945-1964. Rio de Janeiro: Civilização Brasileira.

Figueiredo, Argelina. (1978), Intervenções sindicais e o 'Novo Sindicalismo'. Dados, Revista de Ciências Sociais, No. 17, pp. 135-155.

Filgueiras, Vitor A. (2012), Estado e direito do trabalho no Brasil: regulação do emprego entre 1988 e 2008. PhD dissertation in Social Sciences: Universidade Federal da Bahia (UFBA). 
Fischer, Brodwin. (2008), A poverty of rights. Citizenship and inequality in twentiethcentury Rio de Janeiro. Stanford: Stanford University Press.

Florentino, Manolo, ed. (2005), Tráfico, cativeiro e liberdade: Rio de Janeiro, séculos XVIII-XIX. Rio de Janeiro: Civilização Brasileira.

Fontes, Paulo. (2008), Um Nordeste em São Paulo. Trabalhadores migrantes em São Miguel Paulista (1945-1966). Rio de Janeiro: FGV.

Foster, Deborah; Scott, Peter J. eds. (2003), Trade unions in Europe: Meeting the challenge. Brussels; New York: P. Lang.

Fraga Filho, Walter. (2006), Encruzilhadas da liberdade. Estórias de escravos e libertos na Babia (1870-1910). Campinas: Editora da Unicamp.

Fragoso, João; Florentino, Manolo. (2001), O Arcaísmo como projeto. Rio de Janeiro: Civilização Brasileira.

Fragoso, João. (2000), 'O Império escravista e a república dos plantadores', in Linhares, Maria Yeda ed., História Geral do Brasil. Rio de Janeiro: Editora Campus (9th edition), pp. 144-187.

Franco, Maria Sylvia de C. (1976), Homens livres na ordem escravocrata. São Paulo: Ática. Freeman, Richard B. (2000), 'Single peaked vs. diversified capitalism: The relation between economic institutions and outcomes.' NBR Working Paper No. 7556, National Bureau of Economic Research: Cambridge, Massachusetts. French, John D. (2004), Drowning in laws. Labor law and Brazilian political culture. Chapel Hill and London: University of North Carolina Press.

French, John D. (2010), How the not-so-powerless prevail: Industrial labour market demand and the contours of militancy in mid-twentieth-century São Paulo, Brazil. Hispanic American Historical Review, Vol. 90, No. 1, pp. 109-142. Freyre, Gilberto. (1994 [1933]), Casa Grande \& Senzala: formação da familia brasileira sob o regime da economia patriarcal. Rio de Janeiro: Record (29th edition). Furtado, Celso. (1959), Formação econômica do Brasil. Rio de Janeiro: Fundo de Cultura.

Garcia, Afrânio; Palmeira, Moacir. (2001), 'Rastros de casas-grandes e de senzalas: Transformações sociais no mundo rural brasileiro', in Ignacy Sachs et al. eds., Brasil, um Século de Transformações. São Paulo: Companhia das Letras, pp. 38-77.

Gitahy, Leda. (1997), Reconfigurando as redes institucionais: Relações interfirmas, trabalho e educação na indústria de linha branca. Educação \& Sociedade, Vol. 18, No. 61, pp. 228-253.

Gomes, Angela de C. (1979), Burguesia e trabalho. Política e legislação social no Brasil, 1917-1937. Rio de Janeiro: Campus.

Gomes, Ângela de C. (1988), A Invenção do Trabalbismo. Rio de Janeiro: IUPERJ/Vértice. 
Gomes, Angela de C.; Silva, Fernando T. eds. (2013), A justiça do trabalho e sua história. Campinas: Editora da Unicamp.

Gomes, Flávio dos S. (2006), A Hidra e os pântanos. Mocambos e quilombos no Brasil escravista (Séculos XVII a XIX). São Paulo: Editora Unesp.

Guimarães, Nadya A. (2004), Caminhos cruzados. São Paulo: Editora 34.

Guimarães, Nadya A. (2007), Trajetórias inseguras, autonomização incerta: os jovens e o trabalho em mercados sob intensas transições ocupacionais. (Available at http://www.centrodametropole.org.br/pdf/2007/nadyaã03. pdf. Accessed July 2007).

Guimarães, Nadya A. (2009), À procura de trabalho. Instituições do mercado e redes. Belo Horizonte: Argvmentvm.

Guimarães, Nadya; Silva, Paulo H.; Farbelow, Marcus V. (2008), 'A experiência desigual do desemprego recorrente. Diferenças de gênero e raça nas transições ocupacionais em São Paulo', in Nadya Guimarães et al. eds., Mercados de trabalho e oportunidades. Rio de Janeiro: FGV/FAPERJ.

Habermas, Jurgen. (1987). The theory of communicative action. Life world and system: A critique of functionalist reason. Boston: Beacon Press.

Hall, Michael M.; Pinheiro, Paulo S. (1981), Classe operária no Brasil: Condicõoes de vida e de trabalho, relações com os empresários e o Estado. São Paulo: Brasiliense.

Hasenbalg, Carlos A. (1991), A pesquisa sobre migrações, urbanização, relações raciais e pobreza no Brasil: 1970-1990. Rio de Janeiro: IUPERJ. (Série Estudos, 82).

Hasenbalg, Carlos. (1992), 'O negro na indústria: proletarização tardia e desigual', in Carlos Hasenbalg and Nelson do V. Silva, Relações raciais no Brasil contemporâneo. Rio de Janeiro: Rio Fundo, pp. 101-18.

Hasenbalg, Carlos. (2005 [1979]), Discriminação e desigualdades raciais no Brasil. Belo Horizonte: UFMG.

Heckman, James; Pagés, Carmen. (2000), The Cost of Job Security Regulation: Evidence from Latin American Labour Markets. Working Paper, No. 430, Inter-American Development Bank.

Heckscher, Charles C. (1996), The new unionism: Employee involvement in the changing corporation. New York: A Twentieth Century Fund Book.

Hirata, Helena; Humphrey, John. (1989), Trabalhadores desempregados: trajetórias de operárias e operários industriais no Brasil. Revista Brasileira de Ciências Sociais, No. 11, Ano 5. (Available at http:/ /www.anpocs.org.br/ portal/publicacoes/rbcs_00_11/rbcs11_05.htm, accessed in Sept. 2015).

Holloway, Thomas H. (1997), Polícia no Rio de Janeiro. Repressão e Resistência Numa Cidade do Século XIX. Rio de Janeiro: FGV.

Honneth, Axel. (2003), Luta por reconhecimento: A gramática moral dos conflitos sociais. Trad. Luiz Repa. São Paulo: Editora 34. 
Huggins, Martha K. (1985), From slavery to vagrancy in Brazil: Crimes and social control in the Third World. New Brunswick: Rutgers University Press.

Humphrey, John. (1982), Fazendo o milagre. Controle capitalista e luta operária na indústria automobilística brasileira. Petrópolis: Vozes/Cebrap.

Hutchinson, Bertrand ed. (1960), Mobilidade e trabalho. Rio de Janeiro: Centro Brasileiro de Pesquisas Educacionais.

IBGE (Brazilian Institute of Geography and Statistics). (1941), Repertórios estatísticos do Brasil. Quadros retrospectivos. Rio de Janeiro, IBGE, vol. 1.

IBGE (Brazilian Institute of Geography and Statistics). (1987), Estatísticas históricas do Brasil. Rio de Janeiro: IBGE. (Séries Estatísticas Retrospectivas, vol. 3; Séries Econômicas, Demográficas e Sociais, 1550-1985).

IBGE (Brazilian Institute of Geography and Statistics). (2002). Indicadores Sociais 2001. Sindicatos. Rio de Janeiro: IBGE.

IBGE (Brazilian Institute of Geography and Statistics). (2003), Estatísticas do Século XX. Rio de Janeiro: IBGE.

IBGE (Brazilian Institute of Geography and Statistics). (various years), Anuário Estatístico do Brasil. Rio de Janeiro: IBGE.

International Labour Office (ILO). (1997). World Employment Report 1996-97. Geneva: Bureau of Public Information.

International Labour Office (ILO). (2011), World of work magazine. No. 71, April (in http://www.ilo.org/global/publications/magazines-and-journals/ world-of-work-magazine/issues/WCMS_154579/lang--en/index.htm, accessed in Jan-2012).

Jinkings, Nize M. T. (2002). O mister de faz̧er dinheiro: Automação e subjetividade no trabalho bancário. São Paulo: Boitempo.

Johnson, Lyman L. (1997), The competition of slave and free labor in artisanal production: Buenos Aires, 1770-1815, in Tom Brass, Marcel van der Linden eds., Free and unfree labour: The debate continues. Berna: Peter Lang Academic Publishers, pp.265-280.

Jones, Dan. (1991). Beyond the Toyota production system: The era of lean production, Paper presented at the 5th International Operation Management Conference, Warwick.

Karasch, Mary C. (1987), Slave life in Rio de Janeiro. Princeton: Princeton University Press.

Karepovs, Dainis; Leal, Murilo. (2007), 'Os trotskismos no Brasil', in Marcelo Ridenti and D. A. Reis eds., História do marxismo no Brasil. Partidos e movimentos após os anos 1960. Vol. 6, Campinas: Editora da Unicamp.

Kearney, Richard. (2003), Strangers, gods and monsters. London and New York: Routledge. 
Keck, Margareth E. (1988), 'O 'novo sindicalismo' na transição brasileira', in Alfred Stepan (ed.), Democratizando o Brasil. Rio de Janeiro: Paz e Terra.

Keck, Margareth E. (1992), Worker's Party and democratization in Brazil. Yale: Yale University Press.

Kern, Horst; Sabel, Charles F. (1992). 'Trade unions and decentralized production: A sketch of strategic problems in the German labour movement', in Marino Regini, ed. The Future of Labour Movements. London: Sage, pp. 217-249.

Klein, Herbert S. (1969), The trade in African slaves to Rio de Janeiro, 17951811: Estimates of mortality and patterns of voyages. The Journal of African History, Vol. 10, No. 4, pp. 533-549.

Kowarick, Lucio. (1987), Trabalho e Vadiagem. A Origem do Trabalho Livre no Brasil. São Paulo: Brasiliense.

Kristeva, Julia. (1991), Strangers to Ourselves. New York: Columbia University Press.

Kupfer, David. (2004). Política industrial. Econômica, Vol. 5, No. 2, pp. 281-298. Lavinas, Lena ; Cordilha, A. C.; Cruz, G. F. (2014), Assimetrias de gênero no mercado de trabalho brasileiro: rumos da formalização. Cabiers du Mage, Vol. 18, pp. 59-90.

Lemos, Ana H. C. (2003), Qualificação profissional e desemprego: A construção social de um problema. Doctoral dissertation in Sociology, IUPERJ: Rio de Janeiro.

Levine, Robert M. (1998), Father of the poor? Vargas and his era. Cambridge: Cambridge University Press.

Lima, Carlos A. M. (2002), Sertanejos e pessoas republicanas: livres de cor em Castro e Guaratuba (1801-1835). Estudos Afro-asiáticos, Vol.24, no.2, p.317-344.

Lima, Jacob C. (2007), Ligações perigosas: trabalho flexivel e trabalho associado. São Paulo: Annablume.

Linden, Marcel van der. (2005), Rumo a uma nova conceituação histórica da classe trabalhadora mundial. História Vol.24, No.2, pp. 11-40.

Linhares, Maria Yedda L.; Teixeira, Francisco Carlos S. (1998), Terra Prometida. Uma história da questão agrária no Brasil. Rio de Janeiro: Campus.

Lobo, Valéria M. (2010), Fronteiras da cidadania: Sindicatos e (des)mercantilização do trabalho no Brasil. Belo Horizonte: Argvmentvm.

Lopes, José Sergio L. (1976), O Vapor do diabo. O trabalho dos operários do açúcar. Rio de Janeiro: Paz e Terra.

Lopes, Juarez B. (1967), Crise do Brasil arcaico. São Paulo: Difusão Europeia do Livro.

Lopes, Juarez B. (1971[1964]), Sociedade industrial no Brasil. 2nd. ed. São Paulo: Difusão Europeia do Livro. 
Lowenstein, Karl. (1942), Brazil under Vargas. New York: The MacMillan Company.

Löwy, Michael. (2007), 'Cristianismo da libertação e marxismo: de 1960 a nossos dias', in Marcelo Ridenti and Daniel A. Reis eds., História do marxismo no Brasil. Partidos e movimentos após os anos 1960. Vol. 6, Campinas: Editora da Unicamp.

Luhmann, Niklas. (1996), Confianz̧a. Barcelona: Anthropos. [First German edition: 1973]

Luna, Francisco V. e Klein, Herbert S. (2003), The slave economy and society of São Paulo, 1750-1850. Stanford: Stanford University Press.

Machado da Silva, Luiz A. (1971), Mercados metropolitanos de trabalho manual e marginalidade. Master Thesis: Museu Nacional - UFRJ.

Machado, Cacilda. (2006), O patriarcalismo possível: relações de poder em uma região do Brasil escravista em que o trabalho familiar era a norma. Revista Brasileira de Estudos Populacionais, v. 23, n. 1, p. 167-186, jan./jun.

Machado, Maria Helena. (1994), O plano e o pânico. Os movimentos sociais na década da Abolição. Rio de Janeiro/São Paulo: UFRJ/EDUSP.

Maciente, Aguinaldo N.; Araújo, Thiago C. (2011), Requerimento técnico por engenheiros no Brasil até 2020. Radar: tecnologia, produção e comércio exterior, Vol. 12, p. 43-54.

Maram, Sheldom L. (1977), 'The immigrant and the Brazilian labour movement, 1890-1920', in Dauril Alden and Warren Dean eds. Essays concerning the socioeconomic history of Brazil and Portuguese India. Gainesville: University of Florida Press, pp. 178-210.

Marques, Gustavo; Pagés, Carmen. (1998), Ties that bind: Employment protection and labour market outcomes in Latin America. Inter-American Development Bank (available at http://www.iadb.org/res/publications/pubfiles/ pubWP-373.pdf, accessed in Sept. 2015).

Martinello, Pedro. (2004), A batalha da borracha na Segunda Guerra Mundial. Rio Branco: EDUFAC.

Martinez, Paulo H. (2007), 'O Partido dos Trabalhadores e a conquista do Estado', in Marcelo Ridenti and D. A. Reis eds., História do marxismo no Brasil. Partidos e movimentos após os anos 1960. Vol. 6, Campinas: Editora da Unicamp. Martins Rodrigues, Leôncio. (1966), Conflito industrial e sindicalismo no Brasil. São Paulo: Difusão Européia do Livro.

Martins Rodrigues, Leôncio. (1970), Industrialização e atitudes operárias: Estudo de um grupo de trabalhadores. São Paulo: Brasiliense.

Martins Rodrigues, Leôncio. (1974), Trabalhadores, sindicatos e industrializạąão. São Paulo: Brasiliense. 
Martins Rodrigues, Leôncio. (1989), Partidos e sindicatos: Estudos de sociologia política. São Paulo: Ática.

Martins, Heloisa H. T. (1989). O Estado e a burocratização do sindicato no Brasil. São Paulo: HUCITEC (2nd edition, first in 1978).

Martins, José de Souza. (1979), O Cativeiro da Terra. São Paulo: C. Humanas.

Marx, Karl. (2012), As lutas de classe na França de 1948 a 1950. São Paulo: Boitempo.

Marx, Roberto; Salerno, Mario S.; Zilbovicius, Mauro. (2003), The automobile industry in Brazil:production strategies and best practices in supply chain management. Paper presented at EUROMA - POMS Joint International Conference, Como. One World? One View of OM? The Challenges of Integrated Research and Practices. Manuscript.

McCabe, Darren; Black, John. (1997), 'Something's gotta give': trade unions and the road to team working. Employee Relations, Vol. 19, No. 2, pp. 110-127.

Medeiros, Marcelo; Soares, Sergei; Souza, Pedro; Osorio, Rafael. (2014), 'Inequality, poverty, and the Brazilian social protection system,' in Jan $\mathrm{N}$. Pieterse and Adalberto Cardoso eds., Brazil emerging: inequality and emancipation. New York: Routledge, pp. 32-49.

Medeiros, Marcelo; Souza, Pedro; Castro, Fabio A. (2014), A estabilidade da desigualdade de renda no Brasil, 2006 a 2012. (Available at http://iepecdg. com.br/uploads/artigos/SSRN-id2479685.pdf. accessed in Dec. 2014).

Mello e Silva, Leonardo; Rizek, Cibele S. (1997), Algumas Observações sobre a Qualificação do Trabalho no Complexo Químico Paulista. Anais do XXI Congresso da ALAS, São Paulo, pp. 57-58.

Mendes, René. (2003), 'Produção científica brasileira sobre saúde e trabalho, publicada na forma de dissertações de mestrado e teses de doutorado, 1950-2002.' Revista Brasileira de Medicina do Trabalho, http:/ /www.anamt. org.br/downloads/revista02.zip.

Merrick, Thomas W. (1986), 'A População brasileira a partir de 1945', in Edmar Bacha and Herbert S. Klein eds., A Transição incompleta: Brasil desde 1945. Rio de Janeiro: Paz e Terra, vol. 1, pp. 31-72.

Misse, Michel. (1999), Malandros, marginais e vagabundos. Acumulação social da violência no Rio de Janeiro. Tese de Doutorado em Sociologia, Rio de Janeiro: IUPERJ.

Montali, Lilia T. (s. d.), Salário mínimo e condição de vida. São Paulo, DIEESE. (Available at http://www.dieese.org.br/cedoc/007171.pdf, accessed in June 2009).

Moraes Filho, E. (1979) [1952], O Problema do Sindicato Único no Brasil. São Paulo: Alfa-Ômega. 
Motta, Rodrigo Patto S. (2002), Em guarda contra o perigo vermelho: o anticomunismo no Brasil (1917-1964). São Paulo: Perspectiva/FAPESP.

Moura, Clóvis. (1981), Rebeliões das senzalas. São Paulo, Ciências Humanas, $3^{a}$ edição.

Moura, Denise A. S.. (1998), Saindo das sombras. Homens livres no declínio do escravismo. Campinas: CMU/FAPESP.

Moura, Margarida M. (1978), Os herdeiros da terra. São Paulo: Hucitec.

MTE (Ministério do Trabalho e Emprego). (2004), Inspección del Trabajo en Brasil. Brasilia: MTE. Manuscript.

Nabuco, Joaquim. (1999), O Abolicionismo. Rio de Janeiro: Nova Fronteira.

Negro, Antonio L. (1999), 'Nas origens do 'Novo Sindicalismo': o maio de 59, 68 e 78 na indústria automobilística', in Iram J. Rodrigues ed. (1999), O Novo Sindicalismo vinte anos depois. Petrópolis: Vozes.

Negro, Antonio Luigi e Gomes, Flavio. (2006), Além de senzalas e fábricas: uma história social do trabalho. Revista Tempo Social, Vol. 18, pp. 217-240.

Negro, Antonio Luigi. (2004), Linhas de montagem. O industrialismo nacional-desenvolvimentista e a sindicalização dos trabalhadores. São Paulo: Boitempo.

Neri, Marcelo C. (2010), A nova classe média: o lado brilhante dos pobres (The new middle classe: The bright side of the poor). Rio de Janeiro: FGV/CPS.

Neves, Magda de A. (1995), Trabalho e cidadania: As trabalhadoras de Contagem. Petrópolis: Vozes.

Nogueira, Arnaldo M. (1997), A modernização conservadora do sindicalismo brasileiro: a experiência do sindicato dos metalúrgicos de São Paulo. São Paulo: EDUC.

Nogueira, Maria de A. (2000), 'Os Crimes contra a Organização do Trabalho,' in Gustavo A. Vogel Neto ed., Curso de Direito do Trabalho. Rio de Janeiro: Forense.

Noronha, Eduardo G. (1992), As Greves Na Transição Brasileira. Master Theses, Campinas: Unicamp.

Noronha, Eduardo G. (1994), 'Greves e estratégias sindicais no Brasil', in Carlos A. Oliveira; José F. Siqueira Neto and Marco A. Oliveira eds., O mundo do trabalbo: crise e mudança no final do século. Brasília/São Paulo/Campinas: MTb-PNUD/Cesit/Scritta.

Noronha, Eduardo G. (2000), Entre a lei e a arbitrariedade: mercados e relações de trabalho no Brasil. São Paulo: LTr.

Nun, José. (1969), Superpoblación relativa, ejército industrial de reserva y masa marginal. Revista Latinoamericana de Sociología, No. 5, pp. 178-235.

O'Donnell, Guillermo. (1992). State, various crisis and democracy. Notre Dame: Kellogg Institute; São Paulo: Cebrap.

O'Donnell, Guillermo; Schmitter, Philippe. (1986), Transições do regime autoritário: Primeiras conclusões. São Paulo: Vértice. 
O'Donnell, Guillermo; Schmitter, Phillip; Whithead, Lawrence. (1986): Transitions from authoritarian rule: Latin America. Baltimore/London: The Johns Hopkins University Press.

Offe, Claus. (1984), Contradictions of the Welfare State. Chicago: MIT Press.

Oliveira, Marco A. (2003), Politica trabalbista e relações de trabalho no brasil. Da era Vargas ao governo FHC. Tese de Doutorado em Economia - UNICAMP.

Oliveira Vianna, Francisco J. (1920), Resumo histórico dos inquéritos censitários realizados no Brasil. (available at wnw.ibge.gov.br/home/estatistical populacao/ censohistorico, accessed in Sept. 2007).

Oliveira Vianna, Francisco J. (1922[1918]), Populações meridionais do Brasil: História - Organização - Psicologia. 2nd. ed. São Paulo: Monteiro Lobato.

Oliveira Vianna, Francisco J. (1951), Direito do trabalho e democracia social: O problema da incorporação do trabalhador no estado. Rio de Janeiro: José Olympio.

Oliveira Vianna, Francisco J. (1983[1938]). Problemas de direito corporativo. Brasília: Câmara dos Deputados.

Oliveira Vianna, Francisco J. (1987), Instituições politicas Brasileiras. Belo Horizonte: Itatiaia, 2 vol.

Oliveira, Francisco de. (1972), A economia brasileira: Crítica da razão dualista. Estudos Cebrap, No. 2.

Oliveira, Francisco de. (1988), O surgimento do antivalor. Novos Estudos Cebrap, No. 22, pp.8-28, Outubro.

Oliveira, Marco A. (1994), 'Avanços e Limites Do Sindicalismo Brasileiro Recente', in Carlos A de Oliveira; José F. S. Neto and Marco A. Oliveira eds. O Mundo Do Trabalbo: Crise e Mudança No Final Do Século Brasília: MTb-PNUD; São Paulo: Scritta; Campinas: Cesit, pp. 497-518.

Oliveira, Marco A. (2002), Politica trabalbista e relaçôes de trabalho no brasil. Da era Vargas ao governo FHC. Tese de Doutorado em Economia: UNICAMP.

Oliveira, Marco A. (2003). 'Tendências recentes das negociações coletivas no Brasil', in Marco A. Santana and José R. Ramalho eds., Além da fábrica: Sindicatos, trabalhadores e a nova questão social. São Paulo: Boitempo, pp. 271-298.

Palacios, Guillermo. (1997), Imaginário social e formação do mercado de trabalho: o caso do Nordeste Açucareiro do Brasil no século XX. Revista Brasileira de Ciências Sociais, No. 31, pp. 123-139.

Palomino, Héctor; Senén, Cecília. (2005), La inspección del trabajo en Argentina. Paper presented at the seminar 'Labour Inspection and Labour Markets', MIT, January.

Paoli, Maria C. (1988), Labour, law and the state in Brazil, 1930-1950. PhD Dissertation in History, Birkbeck College: University of London. 
Paoli, Maria C.; Sader, Eder; Telles, Vera da S. (1983), Pensando a classe operária: os trabalhadores sujeitos ao imaginário acadêmico. Revista Brasileira de História, Vol. 3, No. 6, pp. 129-149.

Pastore, José. (1997), A agonia do emprego. São Paulo: LTr.

Patto, Maria Helena S. (1999), Estado, ciência e política na Primeira República: a desqualificação dos pobres. Estudos Avançados, Vol. 13, No. 35, pp. 167-198.

Perlman, Janice E. (1977), O mito da marginalidade: Favelas epolítica no Rio de Janeiro. Rio de Janeiro: Paz e Terra. (Coleção Estudos Brasileiros, 18).

Pieterse, Jan N.; Cardoso, Adalberto, eds. (2014), Brazil Emerging. Inequality and emancipation. New York and London: Routledge.

Pinheiro, Paulo Sergio. (1991), Estratégia da Ilusão: a revolução mundial e o Brasil, 1922-1935. São Paulo: Companhia das Letras.

Pinto, Maria Inez Machado Borges. (1994), Cotidiano e sobrevivência. A vida do trabalhadorpobre na cidade de São Paulo (1890-1914). São Paulo: Edusp/FAPESP.

Pizzorno, Alessandro. (1974), 'Los sindicatos y la acción política', in Alessandro Pizzorno et al. Eds, Economia y politica en la acción sindical. Passado Y Presente No. 44 (Buenos Aires).

Pizzorno, Alessandro. (1978), 'Political exchange and collective identity in industrial conflict'. in Colin Crouch and Alessandro Pizzorno eds.: The resurgence of class conflict in Western Europe since 1968. London: The MacMillan Press.

Purcell, Kate; Wilton, N.; and Elias, Peter. (2007), Hard lessons for lifelong learners? Mature graduates and mass higher education. Higher Education Quarterly Vol. 61, No.1, pp. 57-82.

Queiroz, Maria Isaura P. (1965), O messianismo - no Brasil e no mundo. São Paulo: Dominus.

Rachid, Alessandra. (2000), Relaģẽes entre grandes e pequenas empresas de autopeças: Um estudo sobre a difusão de práticas de organização da produção. $\mathrm{PhD}$ Dissertation, Campinas: UNICAMP.

Rainho, Luiz F.; Bargas, Osvaldo. (1983), As lutas operárias e sindicais dos metalúrgicos em São Bernardo (1977-1979). São Bernardo do Campo: Fundo de Greve.

Reis, Daniel A. (2007), 'A trajetória do Partido Comunista no Brasil entre 1943 e 1964', in Marcelo Ridenti and Daniel A. Reis eds., História do marxismo no Brasil. Partidos e organizações dos anos 1920 aos 1960. Vol. 5, Campinas: Editora da Unicamp (2nd edition).

Reis, João José. (2003), Rebelião Escrava no Brasil. A história do levante dos Malês em 1835. São Paulo: Companhia das Letras.

Ribeiro, Pedro J. F. (2008), Dos sindicatos ao governo: a organização nacional do PT de 1980 a 2005. PhD. dissertation in Political Sciences, University of São 
Carlos (available at http://pct.capes.gov.br/teses/2008/33001014026P2/ TES.pdf, accessed in Nov. 2010).

Ridenti, Marcelo. (2010), O fantasma da revolução brasileira. São Paulo: Editora Unesp (2nd revised edition).

Ridenti, Marcelo; Reis, Daniel A. eds. (2007), História do marxismo no Brasil. Partidos e organizacõos dos anos 1920 aos 1960. Vol. 5, Campinas: Editora da Unicamp (2nd edition).

Rios, Ana L.; Mattos, Hebe M. (2005), Memórias do cativeiro. Família, trabalho e cidadania no pós-abolição. Rio de Janeiro: Civilização Brasileira.

Rodrigues, Iram J. (1999), 'A trajetória do Novo Sindicalismo', in Iram Jácome Rodrigues ed., O Novo Sindicalismo, vinte anos depois. Petrópolis/São Paulo: Vozes/Educ/Unitrabalho, pp. 73-94.

Rodrigues, Iram J. ed. (1999), O Novo Sindicalismo vinte anos depois. Petrópolis: Vozes.

Rodrigues, José Albertino. (1968), Sindicato e Desenvolvimento no Brasil. São Paulo: Difusão Europeia do Livro.

Romita, Arion S. (1998), Direito do trabalho. Temas em aberto. São Paulo: LTr. Rosanvallon, Pierre. (1981), La crise de l'Etat Providence. Paris: Seuil.

Russel-Wood, A. J. R. (1999), "Autoridades ambivalentes. O Estado do Brasil e a contribuição africana para 'a boa ordem na República”', in Maria Beatriz Nizza da Silva (org), Brasil: colonizaçãao e escravidão. Rio de Janeiro, Nova Fronteira, pp. 105-123.

Russel-Wood, A. J. R. (2005), Escravos e Libertos no Brasil Colonial. Rio de Janeiro, Civilização Brasileira.

Sabóia, João. (2000), Desconcentração industrial no Brasil nos anos 90: um enfoque regional. Pesquisa e Planejamento Econômico, Vol. 30, No. 1, pp. 69-116. Sader, Eder S. (1988), Quando novos personagens entram em cena: experiências e lutas dos trabalhadores da Grande São Paulo - 1970-1980. São Paulo: Paz e Terra.

Salerno, Mario S. (1998), Restructuration de la Production et Travail dans Les Entreprises Installées au Brésil, Revue Tiers Monde Vol. XXXIX, No. 154, pp. 306-328.

Sales, Teresa. (1977), Cassacos e corumbas. São Paulo: Ática.

Sallum Jr., Brasílio. (1996), Dos Generais à Nova República. São Paulo: Hucitec. Sampaio, Antônio Carlos J. (2005), 'A produção da liberdade: padrões gerais das manumissões no Rio de Janeiro colonial - 1650-1750', in Manolo Florentino ed., Tráfico, Cativeiro e Liberdade. Rio de Janeiro: Civilização Brasileira, pp. 287-329.

Santana, Marco A. (1998), O 'Novo' e o 'Velho' sindicalismo: análise de um debate. Revista de Sociologia e Politica 10/11, UFPR, SCHLA, pp 19-35. 
Santana, Marco A. (2001), Homens partidos. Comunistas e sindicatos no Brasil. São Paulo: Boitempo.

Santana, Marco A. (2012), Bravos Companheiros: comunistas e metalúrgicos no Rio de Janeiro (1945-1964). Rio de Janeiro: 7Letras

Santos, Wanderley G. (1979), Cidadania e Justiça. Rio de Janeiro: Campus.

Santos, Wanderley G. (2001), O cálculo do conflito. Estabilidade e crise na política brasileira. Belo Horizonte/Rio de Janeiro: UFMG/IUPERJ.

Santos, Wanderley G. dos. (2006), Horizonte do Desejo. Instabilidade, Fracasso Coletivo e Inércia Social. Rio de Janeiro: FGV.

Scapetta, Stefano. (1998), Labour Market Reforms and Unemployment. Lessons from the Experience of the OECD Countries. Working Paper No. 382, Inter-American Development Bank: Office of the Chief Economist. Schmitter, Philippe C. (1971), Interest Conflict and Political Change in Brazil. California: Stanford University Press.

Schühly, Gunther F. (1981), Marginalidade: um estudo do 'migrante estabelecido' no Brasil. Rio de Janeiro: PUC/Agir.

Schwarcz, Lilia M. (1987), Retrato em branco e negro: jornais, escravos e cidadãos em São Paulo no final do século XIX. São Paulo: Companhia das Letras.

Schwartz, Stuart B. (1992), Slaves, peasants and rebels. Reconsidering Brazilian slavery. Urbana e Chicago: University of Illinois Press.

Schwartz, Stuart B. (1995), Segredos internos. Engenhos e escravos na sociedade colonial. São Paulo: Companhia das Letras.

Seidman, Gay. (1994), Manufacturing militance. Workers' movements in Brazil and South Africa, 1970-1985. Berkeley: University of California Press.

Seligman, Adam. B. (2000). The problem of trust. Princeton: Princeton University Press.

Sennet, Richard. (2003), Respect in a world of inequality. London: Norton.

Sevcenko, Nicolau. (1984), A revolta da vacina. Mentes insanas em corpos rebeldes. São Paulo: Brasiliense.

Sigaud, Lygia. (1979), Os Clandestinos e os direitos. São Paulo: Duas Cidades.

Silva, Adalberto F. (1982), Ocupação recente das terras do acre: transferência de capitais e disputa pela terra. Belo Horizonte: UFMG.

Silva, Marcelo R. (2002), Inspeção do trabalho. Procedimentos fiscais. Goiânia: Ab Editora.

Simão, Azis. (1966), Sindicato e Estado. Suas relações na formação do proletariado de São Paulo. São Paulo: Dominus.

Skidmore, Thomas. (2003), Brasil: de Getúlio a Castelo. Rio de Janeiro: Paz e Terra. (13th. ed.).

Sluyter-Beltrão, Jeff. (2010), Rise and decline of Brazil's New Unionism. The politics of Central Unica dos Trabalhadores. Bern: Peter Lang. 
Soares, Fabio V.; Soares, Sergei; Medeiros, Marcelo; Osório, Rafael. (2006), Programas de transferência de renda no Brasil. Impactos sobre a desigualdade. Paper presented to the 2006 ANPEC meeting. (Available at http:/ /www.anpec. org.br/encontro2006/artigos/A06A156.pdf, accessed in Feb. 2009).

Soares, Glaucio A. D. (1989), Censura durante o regime autoritário. Revista Brasileira de Ciências Sociais, Ano 4, Vol. 10 (available at http:/ / www.anpocs. org.br/portal/publicacoes/rbcs_00_10/rbcs10_02.htm, accessed in Aug. 2011).

Soares, Serguei D. (2011), A desigualdade de renda de 1995 a 2009 e tendências recentes. Texto para Discussão, No. 51, Rio de Janeiro: CEDE (available at http://www.proac.uff.br/cede/sites/default/files/TD51.pdf, accessed in Aug. 2015).

Souza, Alberto de M. (1971), 'Efeitos Econômicos do Salário Mínimo', in A economia brasileira e suas perspectivas. Rio de Janeiro: APEC, pp. 121-127.

Souza, Jessé. (2000), A Modernização Seletiva. Brasília, UnB.

Souza, Laura de M. (2004 [1982]), Desclassificados do ouro: a pobreza mineira no século XVIII. Rio de Janeiro: Graal (4ª edição revista e ampliada).

Squire, Lyn.; Suthiwart-Narueput, Sethaput. (1997), The impact of labour market regulations. The World Bank Economic Review, Vol. 11, No. 1, pp. 119-143.

Standing, Guy. (1999), Global labour flexibility: Seeking distributive justice. London: Blackwell.

Standing, Guy. (2012), The precariat. The new dangerous class. London: Bloomsbury. Stepan, Alfred, (1986), Os militares: Da abertura à Nova República. Rio de Janeiro: Paz e Terra.

Stewart, Paul; Lewchuk, Wayne; Yates, C.; Saruta, M; Danford, Andy. (2001), Patterns of labour control and the erosion of labour standards. Towards an international study of the quality of working life in the automobile industry (Canada, Japan and the UK). Paper presented at the International Seminar 'The Automobile Industry in the Americas'. Rio de Janeiro, March 5-6.

Supiot, Alain. (1994), Critique du Droit du Travail. Paris: Presses Universitaires de France.

Tannembaum, Frank. (1946), Slave and citizen. Boston: Beacon Press.

Tavares de Almeida, Maria H. (1978), Estado e classes trabalhadoras no Brasil (1930-1945). PhD Dissertation in Political Sciences. FFLCH-USP: São Paulo, 2 vols.

Tavares de Almeida, Maria H. (1983), 'O Sindicalismo Brasileiro entre a Conservação e a Mudança', in Maria H. T. de Almeida e Bernard Sorj eds., Sociedade e Politica no Brasil Pós-64. São Paulo: Brasiliense. 
Tavares de Almeida, Maria H. (1992). Crise econômica e organização de interesses: Estratégias do sindicalismo brasileiro nos anos 80, Livre Docência Thesis in Political Sciences. FFLCH-USP: São Paulo.

Telles, Vera da S. (2010), A cidade nas fronteiras do legal e ilegal. São Paulo: Argvmentvm.

Thompson, Edward P. (1987), A formação da classe operária inglesa. Rio de Janeiro: Paz e Terra, 3 vol.

Titmuss, Richard M. (1963), Essays on the Welfare State. London: George Allen \& Unwin.

Tockman, Victor; Martinez, D. (1999), La Agenda Laboral en la Globalización: Eficiencia Económica con Progreso Social. Working Paper, No. 94, ILO Regional Office for Latin America and the Caribbean, Lima, Peru.

Tocqueville, Alexis de. (1991), Lembranças de 1848: as jornadas revolucionárias em Paris. São Paulo: Companhia das Letras.

Touraine, Alain. (1961), Industrialization et Conscience Ouvrière a São Paulo. Sociologie du Travail, Vol. 3, No. 4, October-December.

Turner, Lowell. (1998), Fighting forpartnership: Labour and politics in unified Germany. Ithaca: Cornell University Press.

Turner, Mary ed. (1995), From chattel slaves to wage slaves: The dynamics of labour bargaining in the Americas. Kingston: Ian Randle.

Ulyssea, Gabriel. (2005), Informalidade no mercado de trabalho brasileiro: Uma resenha da literatura. Textos para Discussão, No. 1070. Rio de Janeiro: IPEA.

Vargas, Getúlio D. (1938), A Nova Política do Brasil. Rio de Janeiro: José Olympio, vols. 1-5.

Vargas, Getúlio D. (1941), A Nova Política do Brasil. Rio de Janeiro: José Olympio, vol. 8.

Vargas, Getúlio D. (1952), O governo trabalbista no Brasil. Rio de Janeiro: José Olympio, Vol. 1.

Vargas, Getúlio D. (1969), O governo trabalbista do Brasil. Rio de Janeiro: José Olympio, Vol. 4.

Vellasco, Ivan de Andrade. (2004), As Seducões da Ordem. Violência, Criminalidade e Administração da Justiça: Minas Gerais, Século 19. São Paulo e São Carlos: ANPCS/EDUSC.

Versiani, Flávio Rabelo. (2000), Os escravos que Saint-Hilaire viu. História Econômica e Economia de Empresas, Vol. 3, No. 1, pp. 7-42.

Villela, Annibal V.; Suzigan, Wilson. (2001[1973]), Politica do Governo e Crescimento da Economia Brasileira, 1889-1945. Rio de Janeiro : IPEA (3rd ed.).

Visser, Jelle. (1993), Syndicalisme et désyndicalisation. Les Mouvemant Sociaux, Vol. 162, pp. 17-39. 
Visser, Jelle. (1994), 'European trade unions: The transition years', in Richard Hyman and Anthony Ferner eds. New frontiers in European industrial relations. Oxford: Blackwell, (pp. 80-107).

Weffort, Francisco C. (1970), Sindicatos e política. Livre Docência Thesis in Political Sciences: FFLCH-USP.

Weffort, Francisco C. (1972), Participação e Conflito Industrial: Contagem e Osasco - 1968. Cadernos Cebrap, No. 15.

Weffort, Francisco C. (1978): O populismo na política brasileira. São Paulo: Paz e Terra.

Weinstein, Barbara. (1996), For social peace in Brazil: Industrialists and the remaking of the working class in São Paulo, 1920-1964. Chapel Hill/London: University of North Carolina Press.

Werneck Vianna, Luiz J. (1991): 'Problemas de representação do Novo Sindicalismo', in Tendências recentes do sindicalismo brasileiro. Grupo de Conjuntura No. 42, Rio de Janeiro: IUPERJ, julho.

Werneck Vianna, Luiz J. (1999), Liberalismo e Sindicato no Brasil (4th ed., revised). Belo Horizonte: UFMG.

Western, Bruce. (1997), Between class and market: Post-war unionization in the capitalist democracies. Princeton: Princeton University Press.

Wever, Kirsten S. (1995), Negotiating competitiveness: Employment relations and organizational innovation in Germany and the United States. Boston: Harvard Business School.

Willems, Emilio. (1961), Uma vila brasileira. São Paulo: Difusão Europeia do Livro.

Williams, Daryle. (2001), Culture wars in Brazil. The first Vargas regime, 1930-1945. Duke: Duke University Press.

Wunsch Filho, Victor. (1999), Reestruturação produtiva e acidentes de trabalho no Brasil: Estrutura e tendências. Caderno de Saúde Pública, Vol. 15, No. 1, pp. 41-51. 
About the author: Adalberto Cardoso is $\mathrm{PhD}$ in Sociology (University of São Paulo) and professor at the Institute of Social and Political Studies of the University of the State of Rio de Janeiro (IESP-UERJ). His research interests include economic and historical sociology of work (including slavery) and inequalities, class formation, state building, urban studies and social theory. He has authored and co-authored articles and books comparing Brazil, Argentina, México, England and France. Among his recent publications are Ensaios de sociologia do mercado de trabalho brasileiro, Rio de Janeiro, FGV, 2013; Brazil emerging: inequality and emancipation, New York, Routledge, 2014 (with Jan N. Pieterse); and Globalização e relações industriais na indústria automobilística brasileira, Rio de Janeiro, Edição do Autor, 2015 (an Amazon.com e-book).

Telma Lage (co-author of chap. VI) studied for her PhD under the supervision of Professor Cardoso and is lecturer at the Rio de Janeiro Catholic University (PUC-Rio). 
FORMATO 14 X 21

Tipologia: Garamond (texto) Goudy Old Style (títulos)

Papel: OfFset $90 \mathrm{G} / \mathrm{M}^{2}$ (MIOLO)

SUPREMO $250 \mathrm{G} / \mathrm{M}^{2}$ (CAPA)

CTP, impressão E ACABAMENTO: Editora AUtOgrafia 